\title{
Ninhydrin in synthesis of heterocyclic compounds
}

\author{
Ghodsi Mohammadi Ziarani, ${ }^{\text {a }}$ Negar Lashgari, ${ }^{\text {b }}$ Fereshteh Azimian, ${ }^{\text {a }}$ Hendrik G. Kruger, \\ and Parisa Gholamzadeh ${ }^{\mathrm{a}}$ \\ ${ }^{a}$ Department of Chemistry, Alzahra University, Vanak Square, Tehran, P. O. Box 1993891176, \\ Iran \\ ${ }^{b}$ School of Chemistry, College of Science, University of Tehran, Tehran, Iran \\ ${ }^{c}$ Catalysis and Peptide research Unit, School of Health Sciences, University of KwaZulu-Natal, \\ Durban 4001, South Africa \\ E-mail:gmziarani@hotmail.com;gmohammadi@alzahra.ac.ir
}

DOI: $\underline{\text { http://dx.doi.org/10.3998/ark.5550190.0016.601 }}$

\begin{abstract}
Ninhydrin has been utilized in many heterocyclic preparations and considered as an important building block in organic synthesis. There is a wide range of reactions that include ninhydrin in the synthesis of heterocyclic compounds. This review highlights the advances in the use of ninhydrin as starting material in the synthesis of various organic compounds and drugs in a fully comprehensive way, from its first isolation in 1910 to the end of 2013. There is also a diversity of multi-component reactions of ninhydrin and we highlight the recent reports in this review.
\end{abstract}

Keywords: Ninhydrin, heterocyclic compounds, five-membered heterocycles, six-membered heterocycles, synthetic methods

\section{Table of Contents}

1. Introduction

2. Synthesis of Ninhydrin

3. Synthesis of Five-membered Heterocycles

3.1. N-Heterocyclic compounds

\subsubsection{Pyrroles}

3.1.2. Pyrrolidines and pyrrolizidines

3.1.3. Pyrazolines

3.1.4. Imidazoles and imidazolidines

3.2. O-Heterocyclic compounds

3.2.1. $\gamma$-Lactones

3.2.2. Tetrahydro- and dihydrofurans

3.2.3. Benzofurans and isobenzofurans 


\subsubsection{Dioxolanes}

3.3. S-Heterocyclic compounds

3.3.1. Thiophenes

3.4. N,O-Heterocyclic compounds

3.4.1. Oxazolidines

3.5. N,S-Heterocyclic compounds

3.5.1. Thiazolidines

4. Synthesis of Six-membered Heterocycles

4.1. N-Heterocyclic compounds

4.1.1. Pyridines and piperidines

4.1.2. Pyrimidines

4.1.3. Piperazines and piperazinones

4.1.4. Pyrazines

4.1.5. Quinoxalines

4.1.6. Phthalazinones

4.1.7. Tetrahydroquinolines

4.1.8. Isoquinolines

4.1.9. Pyridazines

4.1.10. Triazines

4.2. O-Heterocyclic compounds

4.2.1. Pyrans

4.2.2. Dioxanes

4.3. N,O-Heterocyclic compounds

4.3.1. Oxazines

4.4. O,S-Heterocyclic compounds

4.4.1. Oxathianes

5. Synthesis of Seven-membered Heterocycles

6. Synthesis of Eight-membered Heterocycles

7. Conclusion

References

\section{Introduction}

Ninhydrin was first made in 1910 by an English chemist Siegfried Ruhemann, who also investigated its reaction with amines and amino acids to form a colored compound. ${ }^{1-2}$ The product of this reaction is a compound known as Ruhemann's purple ( $\mathrm{Rp}){ }^{3-4}$ which has a maximum absorption at $570 \mathrm{~nm}$. Ninhydrin is a stable hydrated product of indane-1,2,3-trione, which is considered to be a very important analytical tool in organic, peptide, biochemical, analytical and forensic sciences (Figure 1). ${ }^{5-10}$ 
<smiles>O=C1c2ccccc2C(=O)C1(O)O</smiles>

1

Ninhydrin

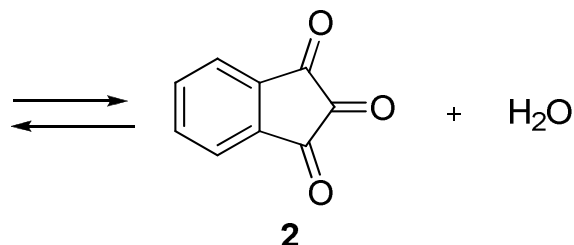

1,2,3-indanetrione

Figure 1. Ninhydrin as the hydrate of indane-1,2,3-trione.

In 1954, Oden and von Hofsten reported the use of ninhydrin as a fingerprint developing reagent that reacts with amino acids secreted from sweat glands. ${ }^{11}$ The possible use of ninhydrin to detect and quantitatively estimate of amino acids/peptides ${ }^{12-20}$ has great importance in revealing latent fingerprints (Scheme 1). ${ }^{21-32}$ Continuous efforts were made to enhance the sensitivity of this technique, ${ }^{33-37}$ and on the synthesis of a broad variety of ninhydrin analogs for utility as efficient reagents to detect amino acids. ${ }^{38}$ The $\mathrm{C}-2$ position of this compound which is situated between two other carbonyl groups, is more reactive towards oxygen, sulfur and carbon-based nucleophiles. Derivatives of indane are also of much interest due to their wide range of biological activities such as antimicrobial, anti-inflammatory, and antagonistic inhibition. ${ }^{39-45}$ Ninhydrin is extensively used to detect compounds of pharmaceutical importance ${ }^{46-57}$ and in kinetic studies. ${ }^{58-59}$

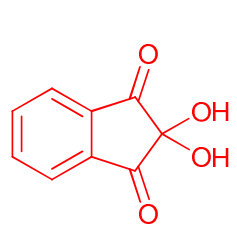

1

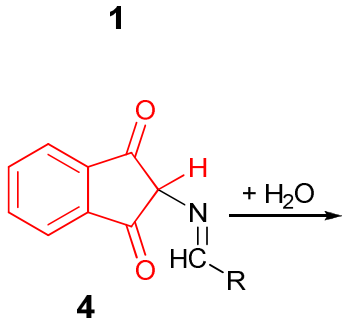

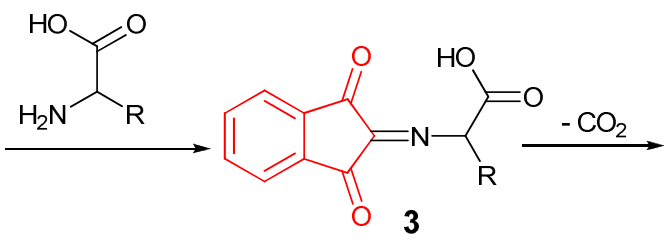

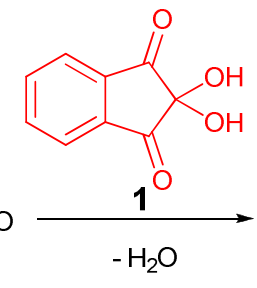<smiles>[R]CN=c1c(=O)c2ccccc2c1=O</smiles><smiles>O=C1C(N=c2c(=O)c3ccccc3c2=O)=C(O)c2ccccc21</smiles>

Ruhemann's purple (RP)

Scheme 1. Reaction of ninhydrin with amino acids.

There are many published articles on the different reactions of ninhydrin, such as amidoalkylation, ${ }^{60}$ Knoevenagel condensation, ${ }^{61}$ oxidation, ${ }^{62-63}$ reduction, ${ }^{64-66}$ aldol addition, ${ }^{67-74}$ cycloaddition, ${ }^{75}$ Friedel-Crafts type reaction, ${ }^{76-83}$ Kolbe-Schmitt, ${ }^{84}$ Passerini, ${ }^{85-92}$ Wittig, ${ }^{93-106}$ and Morita-Baylis-Hillman reactions. ${ }^{107-111}$ Ninhydrin was used in the design and synthesis of various frameworks, both carbocyclic ${ }^{112-119}$ and heterocyclic.

Considering the importance of ninhydrin as a building block in organic synthesis, and as there are a wide range of reactions that include ninhydrin in the synthesis of heterocyclic compounds, we 
have summarized the most prominent reactions in which one of the starting materials was ninhydrin. While various aspects of ninhydrin chemistry have been reviewed elsewhere, including the chemistry, ${ }^{6-7,120-121}$ mechanism, ${ }^{122-126}$ applications, ${ }^{127-129}$ and development of analogues, ${ }^{9-10}$ a literature search revealed that a review dedicated to the application of ninhydrin in the synthesis of heterocyclic compounds is well overdue.

The rest of this review will focus on the distribution of publications involving the use of ninhydrin for preparing of heterocycles. First we introduce different synthetic routes to prepare ninhydrin, and second, we review the use of ninhydrin as a starting material in the synthesis of different heterocyclic compounds, the order being based on the type of heterocycles formed. We attempted to cover all the applications of ninhydrin in heterocyclic syntheses in a fully comprehensive way, from its first isolation in 1910 to the end of 2013. Some medicinal, biological, or pharmacological data and uses of ninhydrin will be mentioned when available

\section{Synthesis of Ninhydrin}

Ninhydrin 1 was first prepared in 1910 from the reaction of l-indanone $\mathbf{6}$ with $N, N$-dimethyl-pnitrosoaniline 7 , followed by subsequent hydrolysis of the imine 8 (Scheme 2 ). ${ }^{2}$ Kametani and coworkers were the first investigators to utilize Ruhemann's methodology to synthesize ninhydrin and two-substituted ninhydrins from the corresponding 1-indanones. ${ }^{130}$
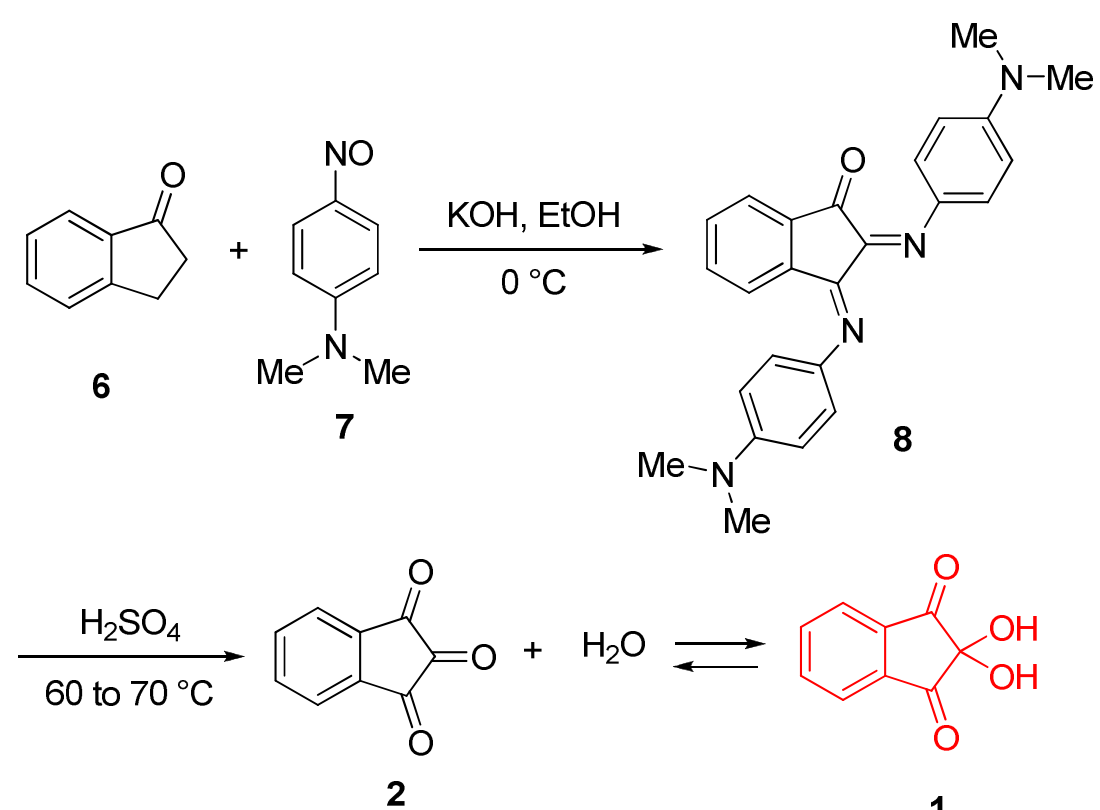

Scheme 2. Synthesis of ninhydrin from the reaction of 1-indanone with $N, N$-dimethyl- $p$ nitrosoaniline.

In 1963, Becker and Russell observed that ninhydrin could be readily synthesized from diethyl phthalate 9 in two steps, with an intramolecular ester condensation leading to the formation of the 
1,3-indanedione system (Scheme 3). ${ }^{131}$ The reaction product isolated upon acidification with hydrochloric acid proved to be the $\alpha$-chloro thioether 13 , which when hydrolyzed in boiling water, results in ninhydrin being isolated in nearly quantitative yields.
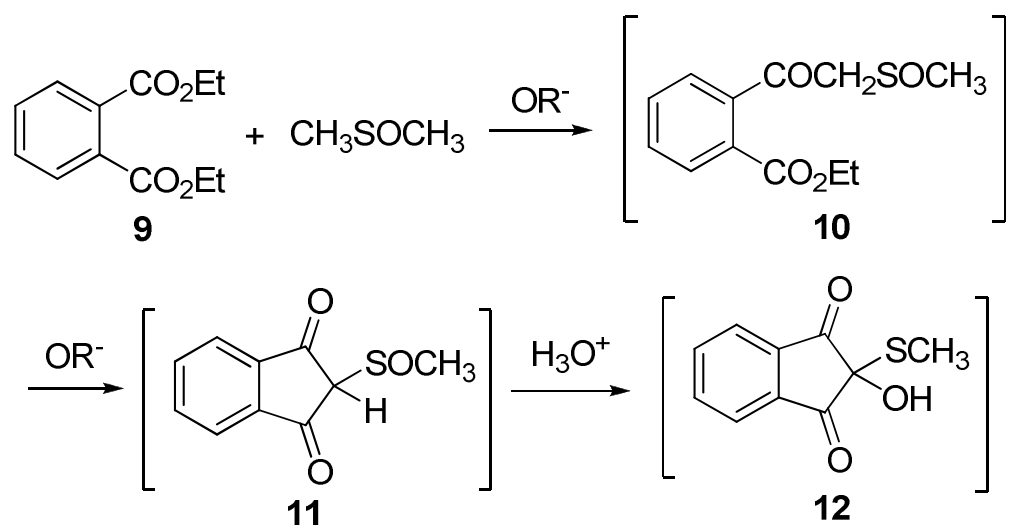<smiles>CC1(Cl)C(=O)c2ccc(O)cc2C1=O</smiles>

13

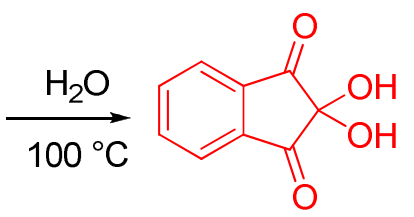

1

Scheme 3. Mechanism that accounts for the synthesis of ninhydrin from diethyl phthalate.

One patent described a process to prepare ninhydrin that consisted of reacting a mixture of oximino-1,3-indanedione, formaldehyde and aqueous acid. ${ }^{132}$ Wasserman and Pickett reported the photo-oxidation of 1,3-indanedione $\mathbf{1 4}$ in the presence of tetrabutylammonium fluoride under standard conditions, with the oxidation being completed within $3 \mathrm{~h}$ to produce a single product $\mathbf{1}$ (Scheme 4). ${ }^{133-134}$ It is worth mentioning that Tatsugi and Yasuji investigated the one-pot synthesis of ninhydrin from 1,3-indanedione by means of N-bromosuccinmide (NBS)-DMSO oxidation with the reaction proceeding at ambient temperature in $94 \%$ yield. ${ }^{135}$

In addition, 1,3-indanedione can be readily oxidized to ninhydrin using selenous acid or selenium dioxide. ${ }^{136-137}$ Sensitized photooxidation (singlet oxygen) of gem-dihaloketones and/or vic-dihaloketones to prepare vic-triketones and/or their monohydrates was reported. ${ }^{138}$ Ninhydrin was also prepared from 1,3-indanedione by nitration, halogenation and decomposition of the nitrohalogenated derivative. ${ }^{139}$ Prakash et al. reported the oxidation of 1,3-indanedione $\mathbf{1 4}$ with iodobenzene diacetate- $\mathrm{ROH}-\mathrm{H}_{2} \mathrm{SO}_{4}$, followed by the acid hydrolysis of the resulting 2,2dialkoxyindane-1,3-diones 16, to provide a new and convenient method for the synthesis of ninhydrin and its ketals (Scheme 5). ${ }^{140}$ 


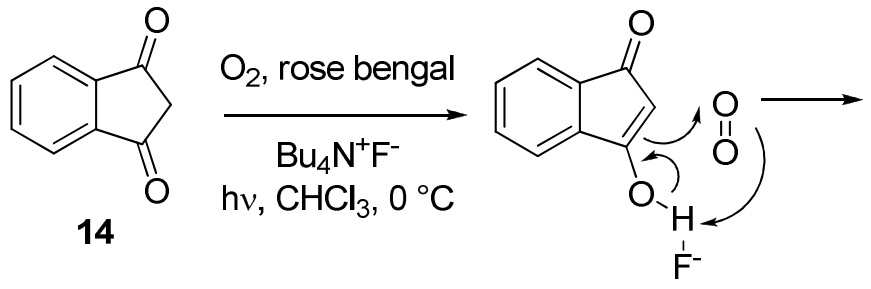<smiles>O=C1C(=O)C(=O)C(O)(COc2ccc3c(=O)c(=O)c(=O)c3c2)C1=O</smiles>

Scheme 4. Mechanism proposed for the photo-oxidation of 1,3-indanedione to prepare ninhydrin.<smiles>O=C1CC(=O)c2ccccc21</smiles>

14<smiles>C=C1c2ccccc2C(=O)C1(OCC)OCC</smiles>

$1649 \%$<smiles>O=C1CC(=C2C(=O)c3ccccc3C2=O)c2ccccc21</smiles>

$1723 \%$

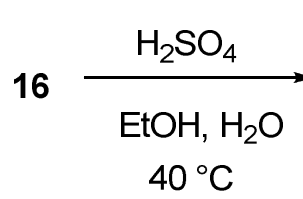<smiles>O=C1c2ccccc2C(=O)C1(O)O</smiles>

$182 \%$

Scheme 5. Preparation of ninhydrin from the oxidation of 1,3-indanedione $\mathbf{1 4}$ with iodobenzene diacetate- $\mathrm{ROH}-\mathrm{H}_{2} \mathrm{SO}_{4}$.

In a related study, Lennard and co-workers synthesized several ninhydrin analogues, and evaluated them as amino acid-specific fingerprint reagents. ${ }^{141-142}$ Treatment of the appropriately substituted 1,3-indanedione $\mathbf{1 4}$ with $p$-toluenesulfonyl azide in the presence of triethylamine afforded the diazo diketone 18. Subsequent reaction of compound 18 with tert-butyl hypochlorite gave the required ninhydrin analogues in good overall yields (Scheme 6). 
<smiles>[R]c1ccc2c(c1)C(=O)CC2=O</smiles>

14

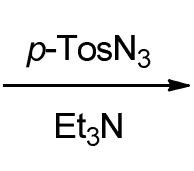

$\mathrm{t}_{3} \mathrm{~N}$

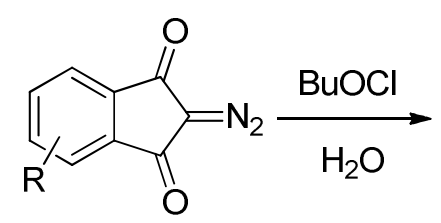

18<smiles>O=C1c2ccccc2C(=O)C1(O)O</smiles>

1

Analogues: Ninhydrin, 4-Methoxyninhydrin, 5-Methoxyninhydrin, 5,6-Dimethoxyninhydrin, 4-Nitroninhydrin, 5-Nitroninhydrin, Tetrachloroninhydrin, Tetrabromoninhydrin, Benzo[f]ninhydrin, Perinaphthoninhydrin

Scheme 6. Synthesis of ninhydrin employing 1,3-indanedione and $p$-toluenesulfonyl azide.

Zenkova and Degterev described the synthesis of ninhydrin by heating 1,2,3,4-tetrahydro-1,4dioxo-2,2,3,3- tetrahydroxynaphthalene (oxolin) on a steam bath. ${ }^{143}$ A study by Heffner et al. toward the synthesis of benzo[f]ninhydrin $\mathbf{2 3}$ as an analogue of ninhydrin reported the Diels-Alder reaction of dibromo-o-xylene $\mathbf{1 9}$ and 4-cyclopentene-1,3-dione $\mathbf{2 0}$ followed by treatment with excess bromine and oxidation of the activated methylene group (Scheme 7). ${ }^{144-145}$ This methodology was optimized and applied to the synthesis of two other ninhydrin analogues, 6methox ybenzo[f]ninhydrin $\mathbf{2 4}$ and thieno[f]ninhydrin $\mathbf{2 5}$. The successful preparation of naphtho[2,3$f$ ]ninhydrin 26 as alternative ninhydrin analogue with excellent potential as a fingerprint reagent was discovered by Hallman and Bartsch. ${ }^{146}$ The synthesis of 5-methoxyninhydrin based on a novel and efficient two step route, which begins with commercially available 6-methoxy-1-indanone 27, was also investigated (Scheme 8). ${ }^{147}$ Ninhydrin was also prepared by a single-stage process from 2acylindane-1,3-diones. ${ }^{148}$

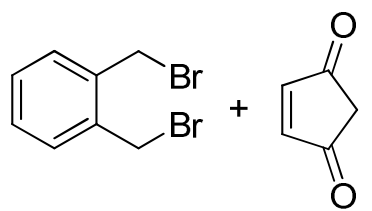

19 $\underset{\text { dioxane, } 25^{\circ} \mathrm{C}}{\stackrel{\mathrm{Zn}}{\longrightarrow}}$

20<smiles>O=C1CC(=O)C2Cc3ccccc3CC12</smiles>

$2183 \%$

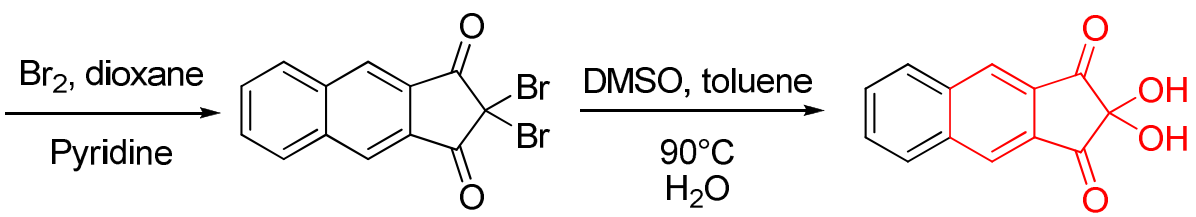

$2294 \%$

$2394 \%$<smiles>COc1ccc2cc3c(cc2c1)C(=O)C(O)(O)C3=O</smiles>

$2495 \%$<smiles>O=C1c2cc3ccsc3cc2C(=O)C1(O)O</smiles>

$2585 \%$<smiles>O=C1c2cc3cc4ccccc4cc3cc2C(=O)C1(O)O</smiles>

$2680 \%$

Scheme 7. Mechanistic explanation of the synthesis of benzo[f]ninhydrin. 
<smiles>COc1ccc2c(c1)C(=O)CC2</smiles>

27

1. NBS (2.1 eq.)

AIBN, $\mathrm{CCl}_{4}$, heat

2. $\mathrm{Et}_{3} \mathrm{~N}$ (3.5 eq.) $99 \%$<smiles>COc1ccc2c(c1)C(=O)CC2(Br)Br</smiles>

28<smiles>COc1ccc2c(c1)C(=O)C(O)(O)C2=O</smiles>

29

NBS $=\mathrm{N}$-bromosuccinimide

AIBN = azobisisobutyronimle

Scheme 8. Two step route for the synthesis of 5-methoxyninhydrin.

\section{Synthesis of Five-membered Heterocycles}

This section involves a range of heterocyclic reactions involving ninhydrin, starting with the synthesis of five-membered heterocyclic compounds in which examples of ninhydrin as a precursor in reactions are presented that led to the construction of several $\mathrm{N}, \mathrm{O}$ and $\mathrm{S}$ containing heterocycles. In this regard, various heterocyclic compounds, such as pyrroles, pyrrolidines, imidazoles, tetrahydrofurans, dihydrofurans, benzofurans, thiophenes, oxazolidines, and thiazolidines are reported, starting with ninhydrin. Various types of reactions, such as cycloaddition, cyclocondensation, Wittig, Pictet-Spengler, Baylis-Hillman, and sequences of reactions as well as multicomponent reactions are included. After this section the synthesis of six-, seven- and eightmembered heterocycles are presented.

\subsection{N-Heterocyclic compounds}

3.1.1. Pyrroles. Ninhydrin has been employed in the architecture of different types of heterocyclic moieties. Pyrroles are important synthons in the synthesis of natural products. ${ }^{149}$ They exhibit remarkable biological properties such as antimicrobial, ${ }^{150}$ anti-inflammatory ${ }^{151}$ and antitumour activities ${ }^{152}$ and are able to inhibit retroviral reverse transcriptases, ${ }^{153}$ cellular DNA polymerases ${ }^{154}$ and protein kinases. ${ }^{155}$ Furthermore, some of these compounds are useful intermediates in the synthesis of biologically important naturally occurring alkaloids ${ }^{156}$ and unnatural heterocyclic derivatives. In 1972, an investigation of a model reaction with ninhydrin 1, phenylacetaldehyde 30, and primary amines showed that heating of equimolar amounts of these components in aqueous methanol affords three interrelated products 31-33, two of which strongly fluoresce upon irradiation (Scheme 9). ${ }^{157}$ 


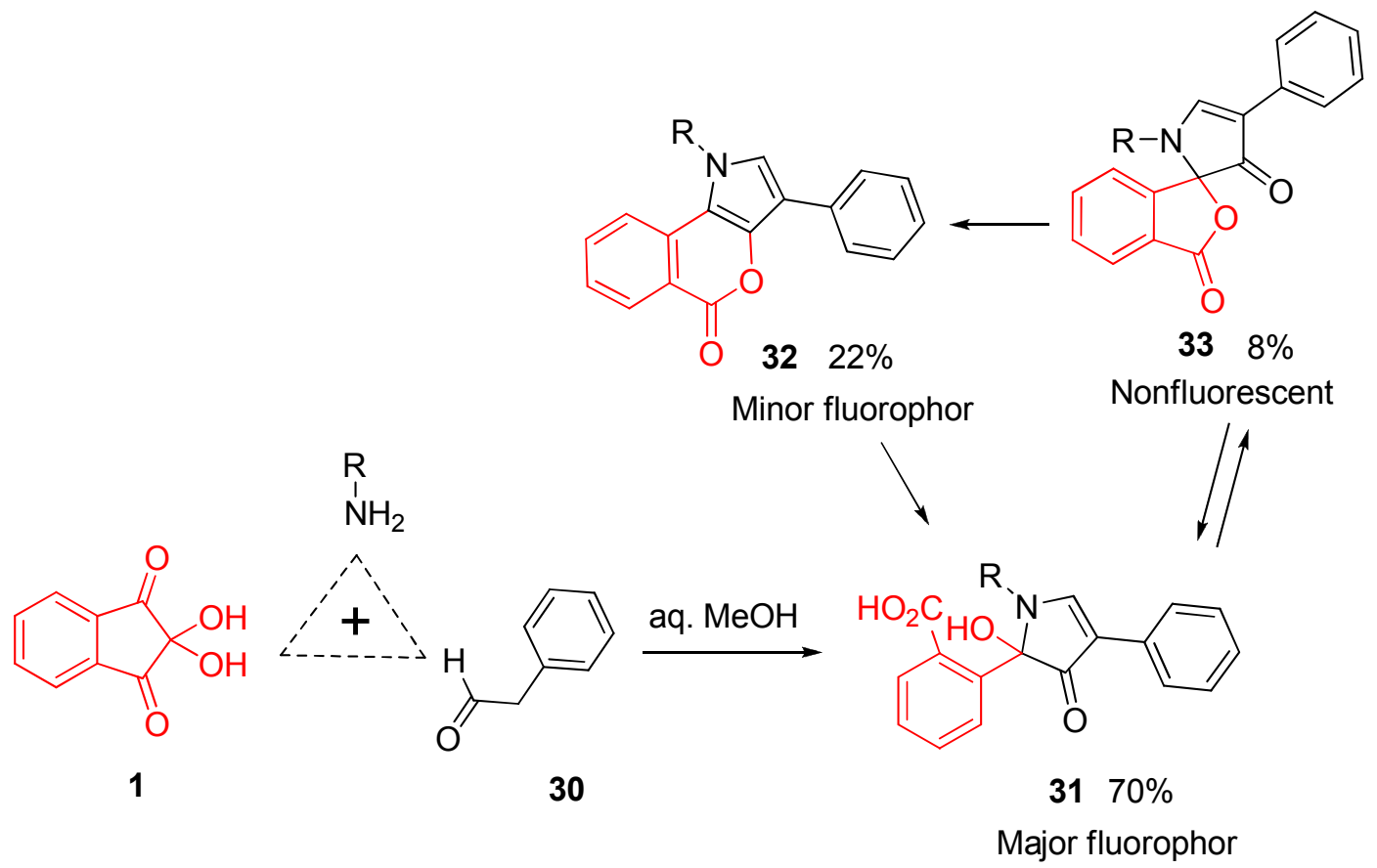

Scheme 9. Three-component synthesis of pyrroles from ninhydrin, phenylacetaldehyde, and primary amines.

In benzene, ninhydrin undergoes electrophilic substitution at $\mathrm{C} 2$ of 3,5-dimethoxyaniline, leading to the indeno[1,2-b]indole $34,{ }^{158}$ which can in turn be transformed into fused indole derivatives 35, 38, 40, the indolenines 36, 37, and the indolone 39 (Scheme 10). ${ }^{159}$ The rate of tetracyclic products formation from the ring-opened products appears to be related to the substitution pattern of the aniline ring. Examples that have an electron-donating group para to the amine can easily cyclize to the tetracyclic product, while in the case of 3,5-dimethoxyaniline, where neither of the methoxy groups are in a para position with respect to the amine, formation of the tetracyclic product is much slower. Anilines, having only one electron-donating group located at the meta position, react para to the amine, and therefore cannot lead to ring closure, resulting in the formation of the tetrahydroindeno[1,2-b]indolone product not being possible. ${ }^{160}$

A one-pot four component procedure for the synthesis of densely functionalized pyrroles $\mathbf{4 6}$ by reacting ninhydrin with phosphorane intermediates $\mathbf{4 3}$ was developed by Azizian et al. (Scheme 11). ${ }^{161}$ The latter is produced from the reaction between triphenylphosphine, ammonium thiocyanate (or ammonium acetate) and various dialkyl acetylenedicarboxylates $\mathbf{4 1}$. The final step of this reaction involves the proton transfer reaction to afford compounds $\mathbf{4 6}$. Thus the compound $\mathbf{4 5}$ may be considered as the primary product of an intramolecular Wittig reaction. 


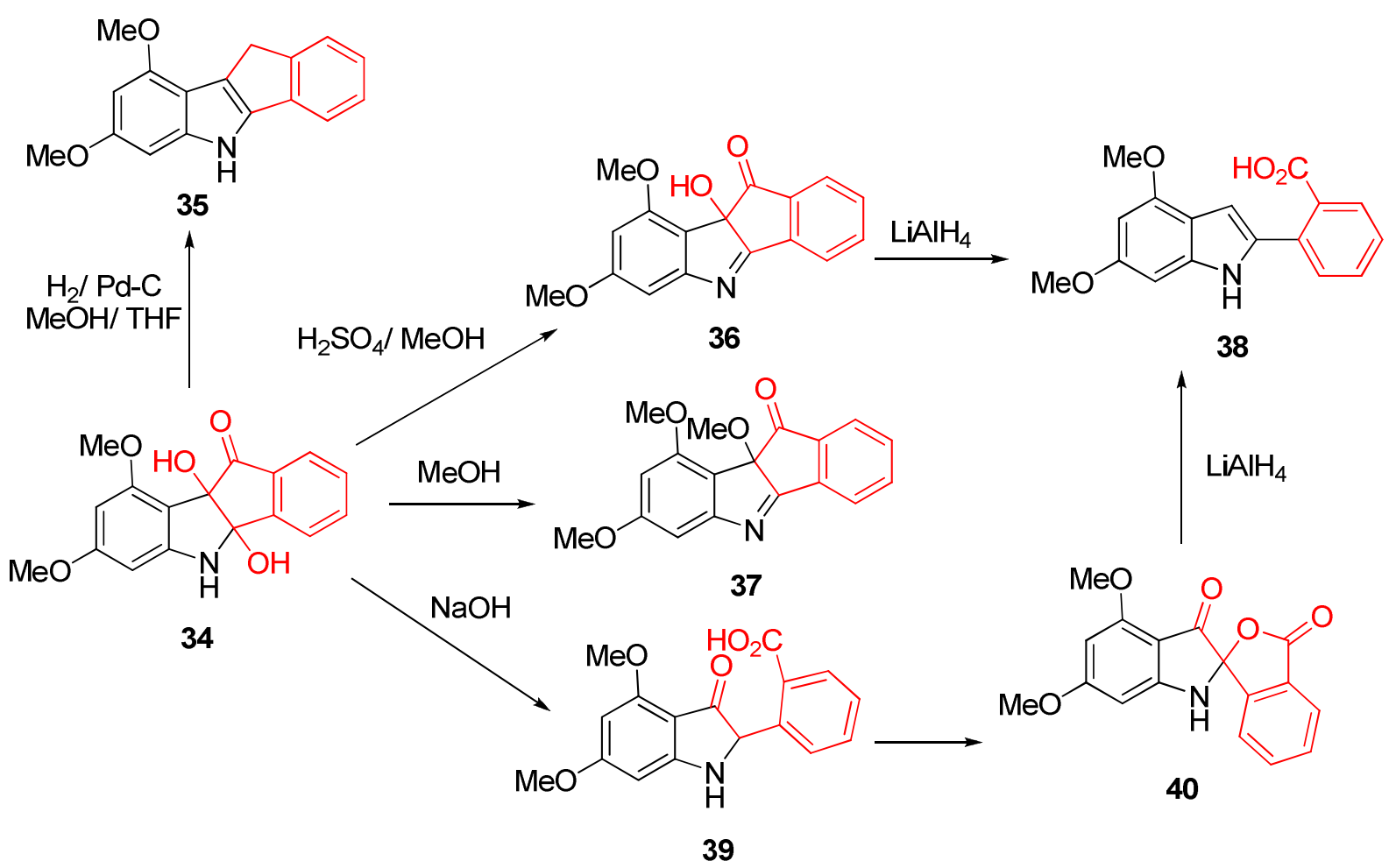

Scheme 10. Synthesis of fused indole derivatives, the indolenines, and the indolone starting from indeno[1,2- $b]$ indole.
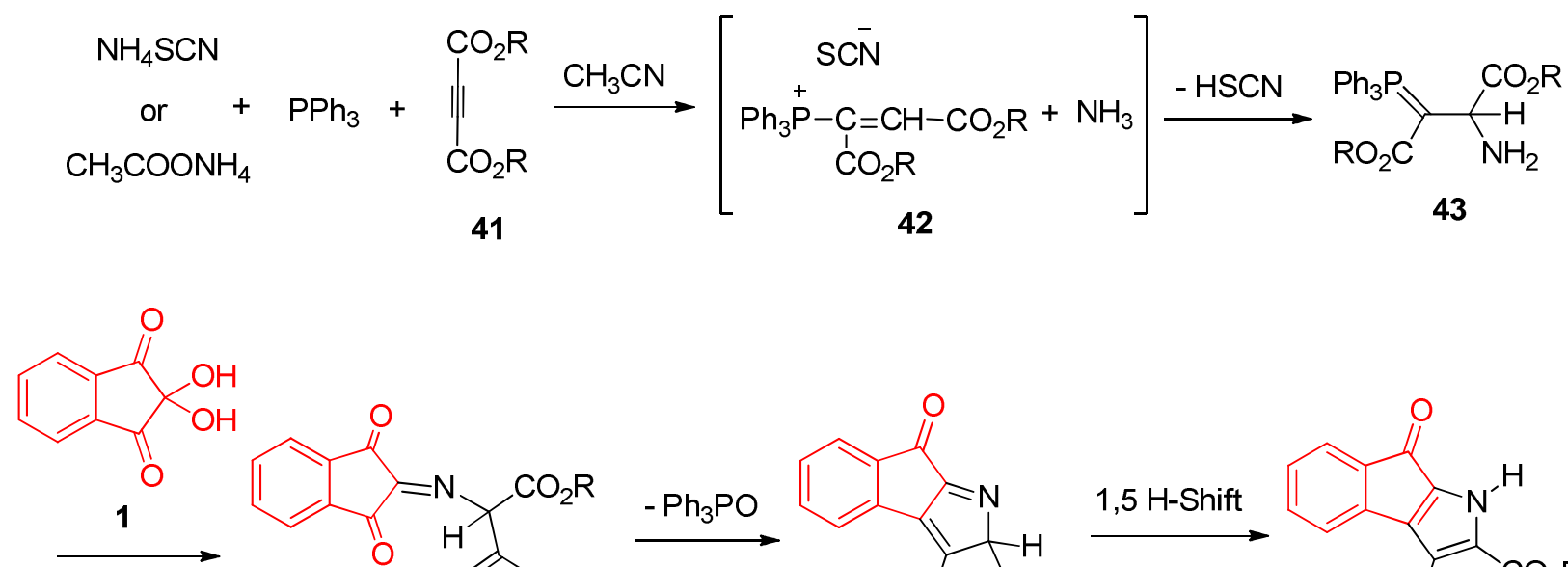<smiles>[R]OC(=O)C(N=c1c(=O)c2ccccc2c1=O)(C(=O)O)C(=O)P</smiles>

44<smiles>[R]OC(=O)c1[nH]c2c(c1C(=O)O[R])-c1ccccc1C2=O</smiles>

45
46

Scheme 11. Mechanistic explanation of the four component synthesis of densely functionalized pyrroles.

More recently, the same group described the synthesis of a racemic mixture of novel tetrahydro3a,8b-dihydroxy-4-oxoindeno[1,2-b]pyrroles $\mathbf{4 9}$ via the three-component reaction of ninhydrin $\mathbf{1}$, 
primary amines, and alkyl propiolates 47 (Scheme 12). ${ }^{162}$ The key step in this synthesis is an efficient reaction of the amine with an alkyl propiolate to give 3-amino acrylate derivative 48, which then reacts with ninhydrin. In another study, Hatamjafari and Montazeri investigated this reaction under microwave irradiation in 4-8 min with $60-87 \%$ yield. ${ }^{163}$
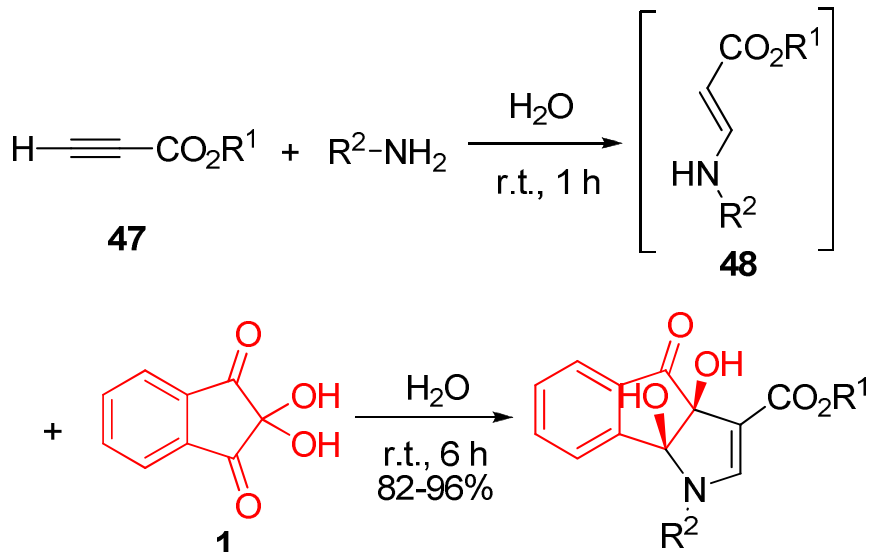

$$
\begin{aligned}
& \mathrm{R}^{1}=\mathrm{Me}, \mathrm{Et} \\
& \mathrm{R}^{2}=\mathrm{Bn}, n-\mathrm{Bu}, c-\text { Hexyl }
\end{aligned}
$$

Scheme 12. Three-component reaction of ninhydrin, primary amines, and alkyl propiolates for the synthesis of tetrahydro-3a,8b-dihydroxy-4-oxoindeno[1,2-b]pyrroles.

Later, Yavari et al. used dialkyl acetylenedicarboxylates $\mathbf{4 1}$ in the above reaction leading to the formation of dialkyl tetrahydro-3a,8b-dihydroxy-4-oxoindeno[1,2-b]pyrrole-2,3-dicarboxylates $\mathbf{5 2}$ (Scheme 13). ${ }^{164}$ The zwitterionic intermediate $\mathbf{5 0}$ formed from the reaction of amine with activated acetylenes, is attacked by ninhydrin to produce $\mathbf{5 1}$. The intermediate $\mathbf{5 1}$ then undergoes cyclization under the reaction conditions employed to produce $\mathbf{5 2}$ as a racemate.

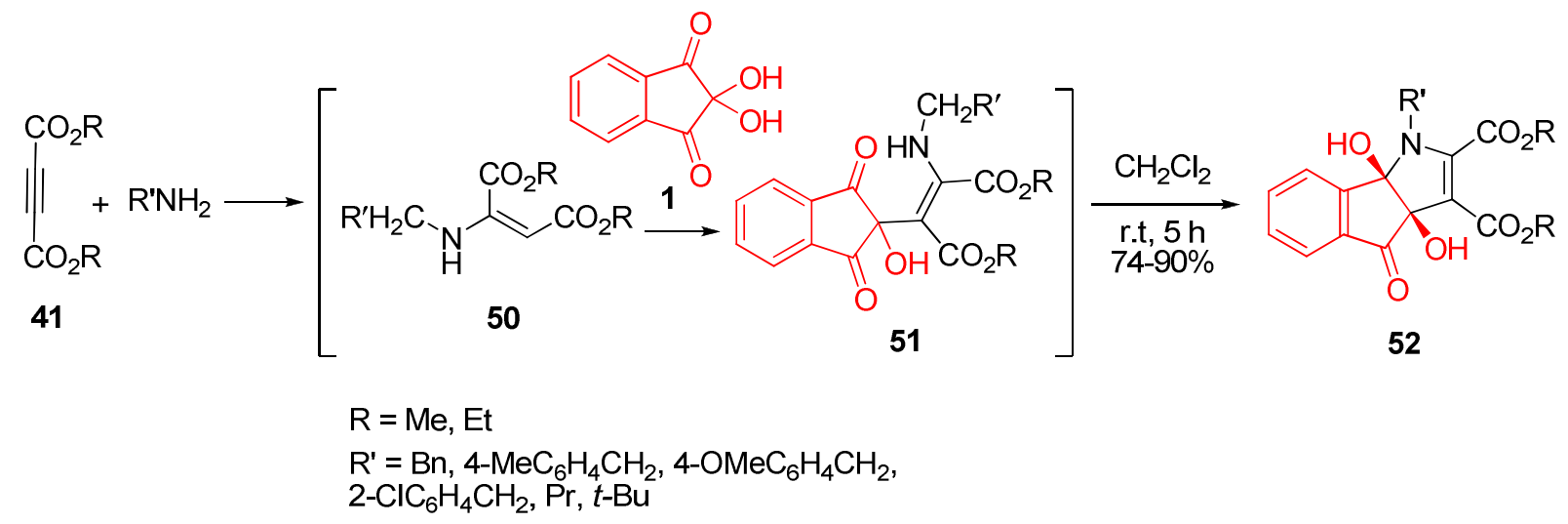

Scheme 13. Mechanism proposed to explain the synthesis of dialkyl tetrahydro-3a,8b-dihydroxy-4oxoindeno[1,2- $b]$ pyrrole-2,3-dicarboxylates. 
Replacing dialkyl acetylenedicarboxylates 41 with 1,1-bis(methylthio)-2-nitroethene $\mathbf{5 3}$ in the reaction with primary amines or 1,n-diamines and ninhydrin was reported by Alizadeh and coworkers (Scheme 14). ${ }^{165}$ The mechanism involves a reaction between nitroketene aminals $\mathbf{5 4}$, derived from the addition of various primary amines or 1,n-diamines to 1,1-bis(methylthio)-2nitroethene, with ninhydrin.

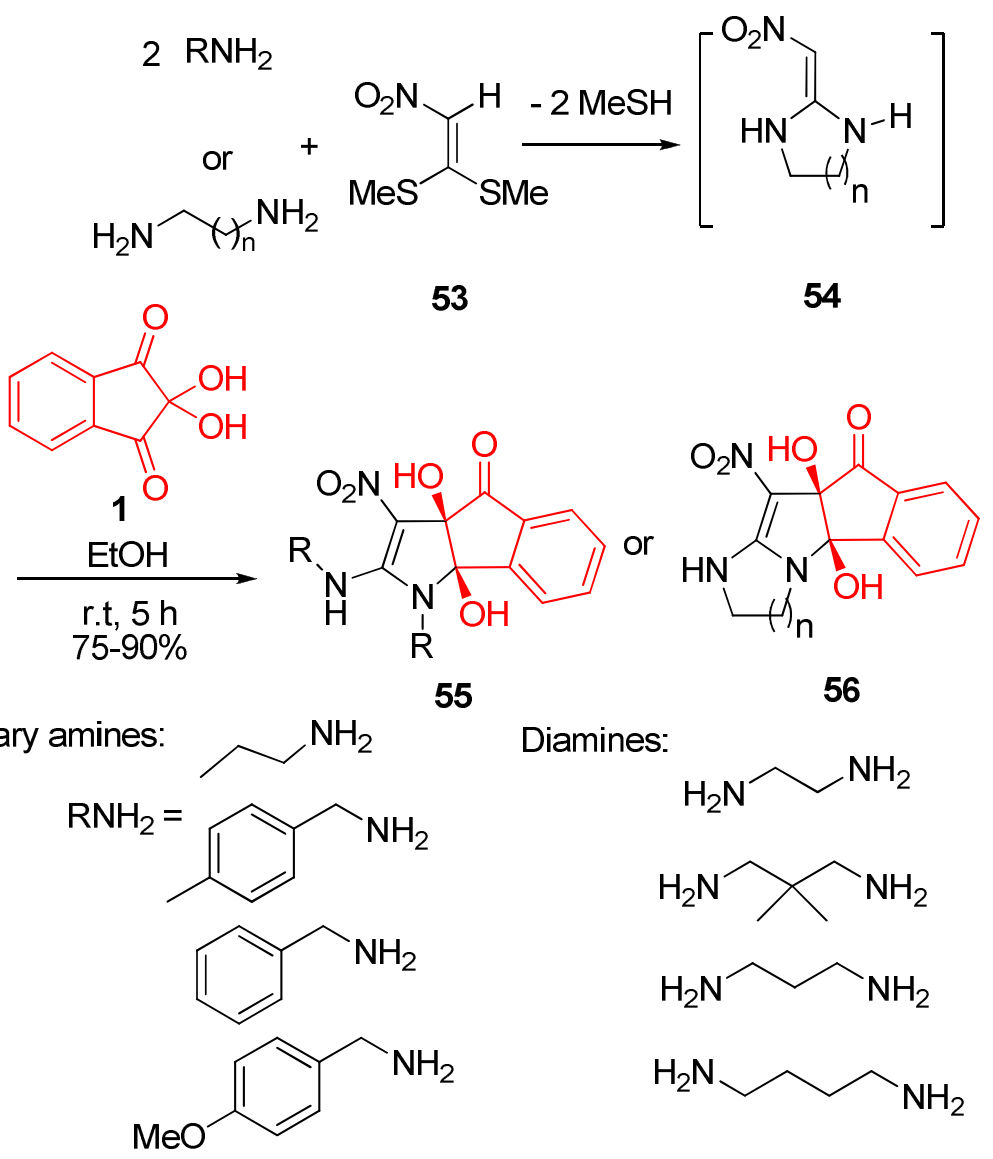

Scheme 14. Mechanism that explains the reaction of various primary amines or 1,n-diamines with 1-bis(methylthio)-2-nitroethene and ninhydrin.

Thereafter, the same group investigated the reaction of ninhydrin $\mathbf{1}$, malononitrile, dialkyl acetylenedicarboxylates 41, and primary amines in water at room temperature and the aza[3.3.3] propellane derivatives $\mathbf{5 8}$ were synthesized in excellent yields (Scheme 15). ${ }^{166}$ In the same report, replacement of the dialkyl acethylenedicarboxylate 41 with alkyl acetoacetate 57 was attempted in order to acquire some newly substituted aza[3.3.3]propellanes $\mathbf{5 9}$ (Scheme 15). 


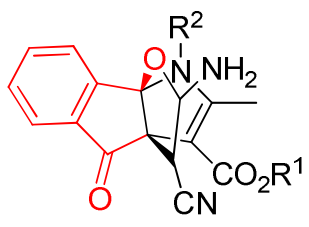

59

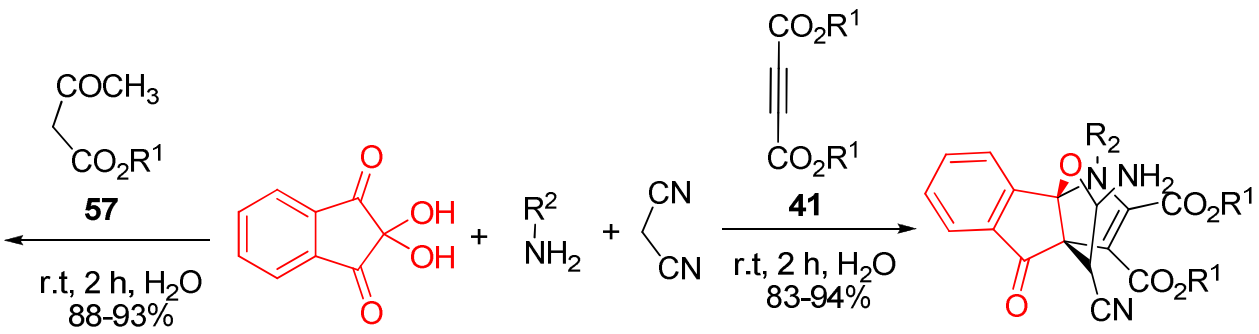

1
$\mathrm{R}^{1}=\mathrm{Me}, \mathrm{Et}$

$\mathrm{R}^{2}=n-\mathrm{Bu}, n-\mathrm{Pr}$
58

$\mathrm{R}^{1}=\mathrm{Me}, \mathrm{Et}$

$\mathrm{R}^{2}=n-\mathrm{Et}, n-\mathrm{Pr}, i-\mathrm{Bu}, n-\mathrm{Bu}$, p-Methylbenzyl, $p$-Methoxybenzyl

Scheme 15. Synthesis of heterocyclic[3.3.3]propellanes via sequential four-component reactions.

As shown in Scheme 16, the same authors also described a chemoselective route to synthesis the highly functionalized fused heterocyclic[3.3.3]propellane via a sequential one-pot four-component reaction. ${ }^{167}$ The syntheses were achieved by reacting ninhydrin with malononitrile to give rise to Knoevenagel adduct, which is trapped in situ by various ketene aminals through conjugate addition and cyclization, providing multi-functionalized oxaaza[3.3.3] propellanes 60-61.

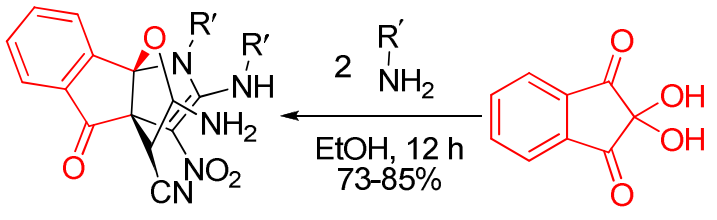

61
Primary amines:<smiles>CCCCN</smiles><smiles>CCCCCCC(C)=C(C)[N+](=O)[O-]</smiles>

53

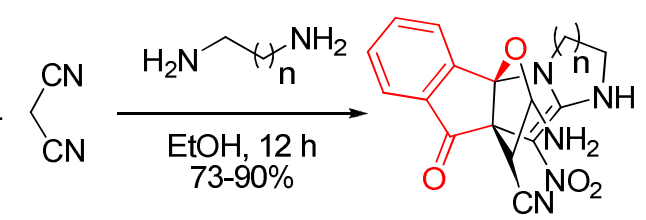

60

Diamines:<smiles>NCCCCN</smiles><smiles>CC(N)CN</smiles><smiles>CC(C)(CN)CN</smiles><smiles>Nc1ccccc1N</smiles>

Scheme 16. Synthesis of fused oxa-aza[3.3.3]propellanes via chemoselective sequential fourcomponent reactions.

In another four-component reaction, the preparation of functionalized 4-(1,3-dioxo-2,3-dihydro1H-2-indenyl) substituted 1-benzylpyrrole-3-carboxylates $\mathbf{6 4}$ via the reaction between ninhydrin $\mathbf{1}$, 1-phenyl-2-(1,1,1-triphenyl- $\lambda^{5}$-phosphanylidene)-1-ethanone 62, primary amines and alkyl acetoacetate $\mathbf{6 3}$ was described (Scheme 17). ${ }^{168}$ 


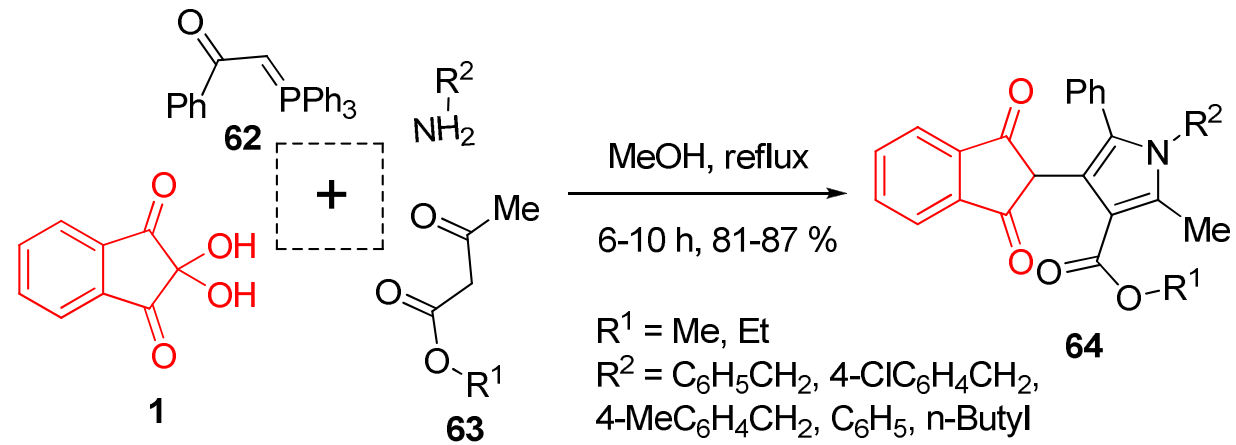

Scheme 17. Four-component synthesis of substituted 1-benzylpyrrole-3-carboxylates.

Ninhydrin 1, primary amines, and 1,3-dicarbonyls $\mathbf{6 3}$ react under solvent-free conditions to afford pyrrole derivatives 65 (Scheme 18). ${ }^{169}$ Cyclic-1,3-diones were also used in this reaction to provide functionalized hydroindeno[1,2- $b]$ indoles. ${ }^{170}$ Reaction of 1,3-dicarbonyl compounds and ninhydrin was also carried out in ethanol/water in the presence of ammonium acetate. ${ }^{171}$ Investigations by Pramanik and co-workers showed that when these adducts 65 are heated on a water bath for 5-20 min in acetic acid with a catalytic amount of conc. $\mathrm{H}_{2} \mathrm{SO}_{4}$, racemic pyrrolefused isocoumarins 69 are formed in very good yields (Scheme 19). ${ }^{172}$ Subsequently, this group of researchers modified this reaction to include the solid-supported Brønsted acid catalyst silica sulfuric acid (SSA). ${ }^{173}$ The methodology has a series of intrinsic advantages, such as easy preparation of the solid supported SSA, reduced energy requirements and manpower usage, easy product isolation/purification and operational simplicity, which lead to a "benign by design" synthetic route.

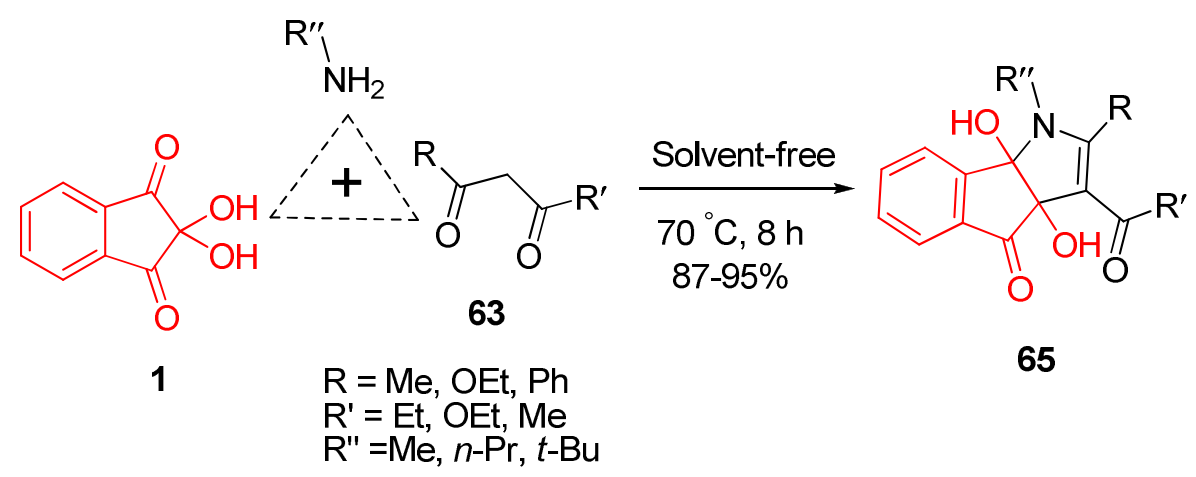

Scheme 18. Three-component synthesis of pyrrole derivatives from ninhydrin, primary amines, and 1,3-dicarbonyls. 


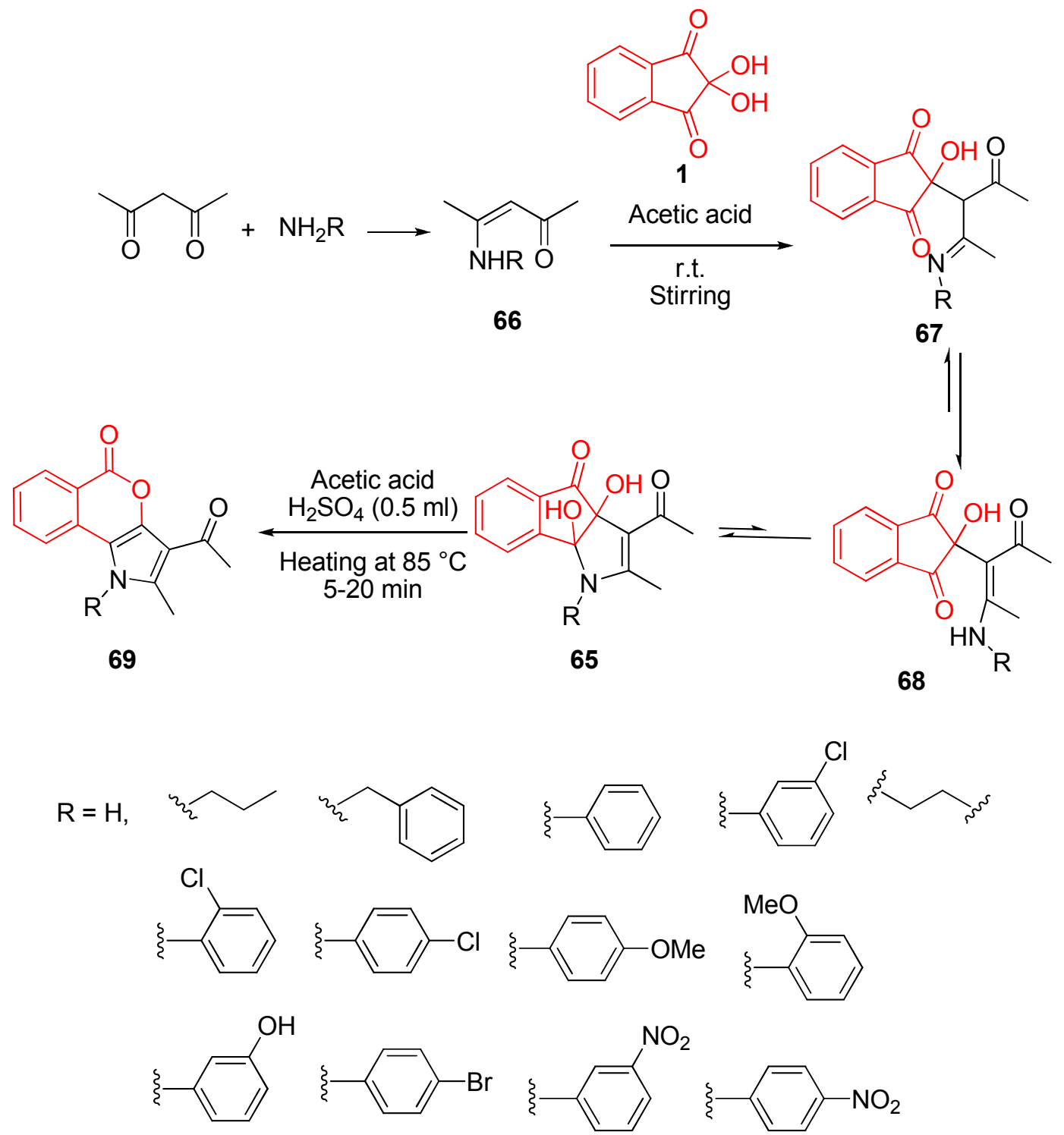

Scheme 19. Mechanism proposed for the pyrrole-fused isocoumarins synthesis.

A facile synthesis of tetracyclic isocoumarins $\mathbf{7 1}$ based on the AcOH-catalyzed cyclocondensation and rearrangement reaction between heterocyclic ketene aminals $\mathbf{7 0}$ and ninhydrin was described by Lin and co-workers (Scheme 20). ${ }^{174}$ This method provided direct access to tetracyclic isocoumarins, a class of compounds with potential broad spectrum biological activities. 
<smiles>O=C1c2ccccc2C(=O)C1(O)O</smiles>

1

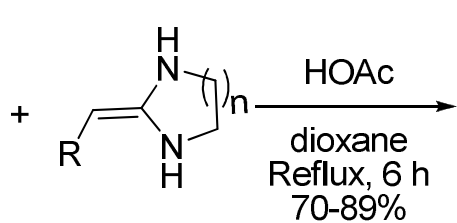

70<smiles></smiles>

71

$$
\begin{aligned}
& \mathrm{R}=\mathrm{CO}_{2} \mathrm{Et}, p-\mathrm{MeOC}_{6} \mathrm{H}_{4} \mathrm{CO}, p-\mathrm{MeC}_{6} \mathrm{H}_{4} \mathrm{CO}, \mathrm{C}_{6} \mathrm{H}_{4} \mathrm{CO}, p-\mathrm{ClC}_{6} \mathrm{H}_{4} \mathrm{CO} \\
& \mathrm{n}=1,2,3
\end{aligned}
$$

Scheme 20. AcOH-catalyzed synthesis of tetracyclic isocoumarins from ketene aminals and ninhydrin.

1,3-Diphenyl-1H-pyrazol-5-amine $\mathbf{7 2}$ in reaction with ninhydrin resulted in the formation of $9 H$-indeno[2',1':4,5]pyrrolo[3,2-c]pyrazol-9-one 73 for the first time (Scheme 21). ${ }^{175}$<smiles>Nc1cc(-c2ccccc2)nn1-c1ccccc1</smiles>

72<smiles>O=C1c2ccccc2C(=O)C1(O)O</smiles>
1

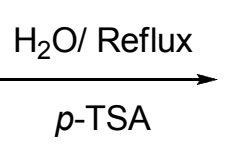

$7 \mathrm{~h}, 68 \%$

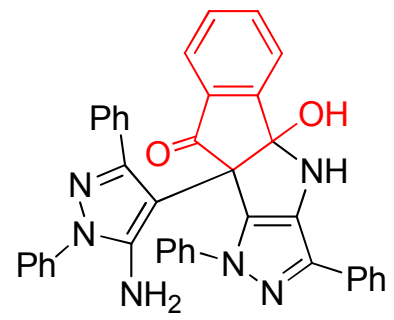

73

Scheme 21. Synthesis of pyrrolo[3,2-c]pyrazol-9-one from ninhydrin and 1,3-diphenyl-1H-pyrazol5-amine.

Hemmerling's group reported the reaction of cyclic enaminones $\mathbf{7 5}$ and ninhydrin $\mathbf{1}$ to yield vicdihydroxy indenoindoles $\mathbf{7 6}$ and the subsequent deoxygenation reaction with $N, N, N^{\prime}, N^{\prime}-$ tetramethylsulfurous diamide, which gave the partially unsaturated indenoindoles 77 (Scheme 22). ${ }^{176-177}$ Thereafter, human protein kinase CK2 inhibition activity of the produced indeno[1,2$b$ ]indole derivatives was evaluated and showed satisfactory results. ${ }^{178-179}$

$\mathrm{Li}$ and co-workers discovered novel multicomponent reactions involving $\mathrm{N}$-heteroannulations of enaminones 75, ninhydrin, and acid anhydride or aromatic amines to selectively produce multifunctionalized indeno[1,2- $b$ ]indoles with different substituted patterns $\mathbf{7 8}$ and $\mathbf{7 9}$ as a racemic mixture (Scheme 23). ${ }^{180}$ 


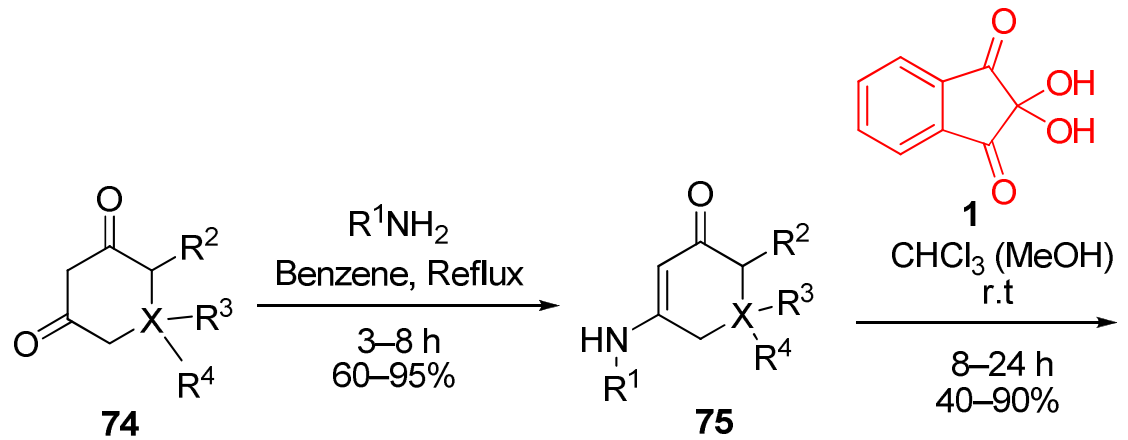<smiles>[R]C1C(=O)C2=C(C[Y]1([R])[R])C1(O)C(=O)c3ccccc3C1(O)N2[R]</smiles>

76<smiles>[R][X]C1([R])Cc2c(c3c(n2[R])-c2ccccc2C3=O)C(=O)C1[R]</smiles>

77

$\mathrm{R}^{1}=\mathrm{H}, \mathrm{Me}, \mathrm{Bn}, \mathrm{Ph}, \mathrm{Pr},\left(\mathrm{CH}_{2}\right)_{5} \mathrm{Me},\left(\mathrm{CH}_{2}\right)_{7} \mathrm{Me}, i-\mathrm{Pr},\left(\mathrm{CH}_{2}\right)_{2} \mathrm{Ph},\left(\mathrm{CH}_{2}\right)_{3} \mathrm{Ph}$,

$\mathrm{CH}(\mathrm{Me}) \mathrm{Ph},\left(\mathrm{CH}_{2}\right)_{3} \mathrm{OEt}, 4-\mathrm{OMeC}_{6} \mathrm{H}_{4} \mathrm{CH}_{2}, 3,4-(\mathrm{OMe})_{2} \mathrm{C}_{6} \mathrm{H}_{3}\left(\mathrm{CH}_{2}\right)_{2},\left(\mathrm{CH}_{2}\right)_{2} \mathrm{NMe}_{2}$,

$\left(\mathrm{CH}_{2}\right)_{3} \mathrm{NMe}_{2}$, 2-pyridylmethyl, $\left(\mathrm{CH}_{2}\right)_{2} \mathrm{OH},\left(\mathrm{CH}_{2}\right)_{3} \mathrm{OH}, \mathrm{CH}_{2} \mathrm{CO}_{2} \mathrm{Me}$

$\mathrm{R}^{2}=\mathrm{H}, \mathrm{CO}_{2} \mathrm{Me}$

$\mathrm{R}^{3}=\mathrm{H}, \mathrm{Me}, \mathrm{Ph}, \mathrm{Bn}$

$\mathrm{R}^{4}=\mathrm{H}, \mathrm{Me}$

$X=C, N$

Scheme 22. Mechanistic explanation of the synthesis of unsaturated indenoindoles.<smiles>[R]C(=O)Oc1cc([R])c([R])c2c1c1c([R])n2c(=O)c2ccccc21</smiles>

Scheme 23. Three component synthesis of multifunctionalized indeno[1,2-b]indoles. 
The synthesis of tetrahydroindeno[2',1':4,5]pyrrolo[2,3- $d]$ pyrimidinetrione derivatives $\mathbf{8 1}$, based on the addition reaction of ninhydrin and 6-aminouracils 80, was developed by Bazgir and coworkers (Scheme 24). ${ }^{181}$ The methodology was later employed in the synthesis of several new $3 H$ spiro[isobenzofuran-1,6'-pyrrolo[2,3-d]pyrimidine]-2',3,4',5'-tetraones 86 based on the reaction of ninhydrin and 6-aminouracils $\mathbf{8 0}$, followed by oxidative cleavage of the corresponding dihydroxyindenopyrrolopyrimidines $\mathbf{8 1}$ (Scheme 25 ). ${ }^{182}$<smiles>O=C1c2ccccc2C(=O)C1(O)O</smiles><smiles></smiles><smiles></smiles>

$8185-92 \%$

Scheme 24. Addition reaction of ninhydrin and 6-aminouracils for the synthesis of tetrahydroindeno[2', 1':4,5]pyrrolo[2,3-d]pyrimidinetrione.

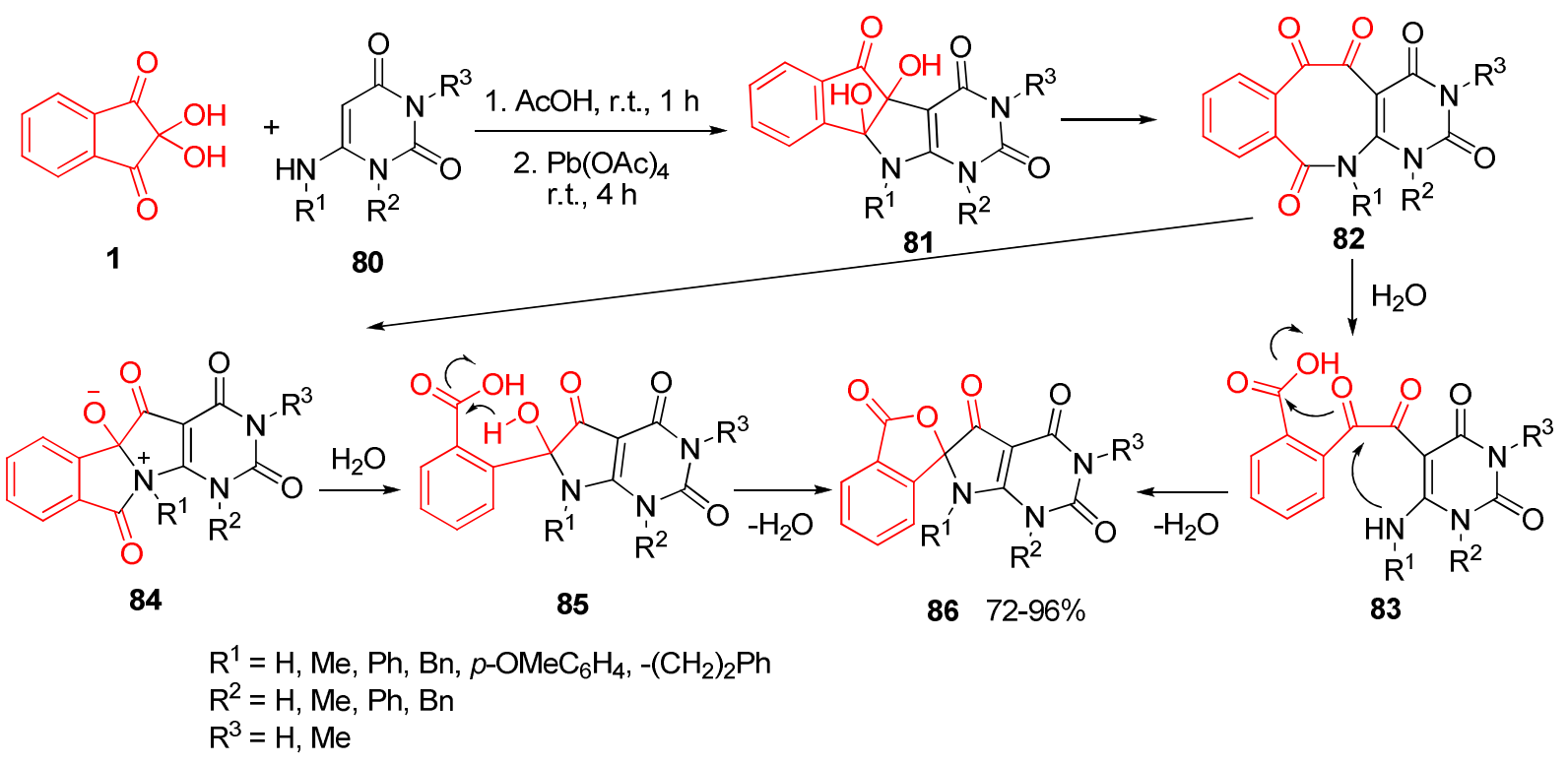

Scheme 25. Mechanism proposed for the $3 H$-spiro[isobenzofuran-1,6'-pyrrolo[2,3- $d$ ]pyrimidine] 2',3,4',5'-tetraones synthesis based on the reaction of ninhydrin and 6-aminouracils.

3.1.2. Pyrrolidines and pyrrolizidines. Pyrrolidines are important core structures in organic chemistry because of their presence in many natural products. ${ }^{183}$ Furthermore, a wide range of biological activities were also observed in compounds possessing a pyrrolidine motif which includes anti-cancer, ${ }^{184}$ antifungal, ${ }^{185}$ and antiviral properties. ${ }^{186}$ Additionally, the family of pyrrolizidine alkaloids continues to provide novel structures with interesting and potentially valuable biological properties. ${ }^{187}$ It has been reported that various substituted pyrrolizidines display versatile pharmacological properties such as antimicrobial ${ }^{188}$ and antitumor activities. ${ }^{189}$ 
Azomethine ylides are a class of powerful reagents that are utilized in 1,3-dipolar cycloaddition reactions that generally afford a range of pharmacologically important heterocyclic compounds. Azomethine ylide $\mathbf{8 7}$ was generated in situ from the reaction of ninhydrin $\mathbf{1}$ and sarcosine, and then used as starting substrate in the synthesis of a variety of $\mathrm{N}$-methyl-spiropyrrolidines (Scheme 26).

Highly regioselective synthesis of new dispiropyrrolidines $\mathbf{8 9}$ containing a thiophenone ring was achieved by a three-component 1,3-dipolar cycloaddition reaction. Unsaturated thiophenone dipolarophiles $\mathbf{8 8}$ were reacted with azomethine ylides $\mathbf{8 7}$ to produce the corresponding cycloadducts in good yields (Scheme 26). ${ }^{190}$ Similarly, 1,4-naphthoquinone $\mathbf{9 0}^{191}$ and bisarylmethylidenecyclohexanones $\mathbf{9 2}{ }^{192}$ reacted with $\mathbf{8 7}$ to form novel spiropyrrolidines $\mathbf{9 1}$ and $\mathbf{9 3}$, respectively (Scheme 26).

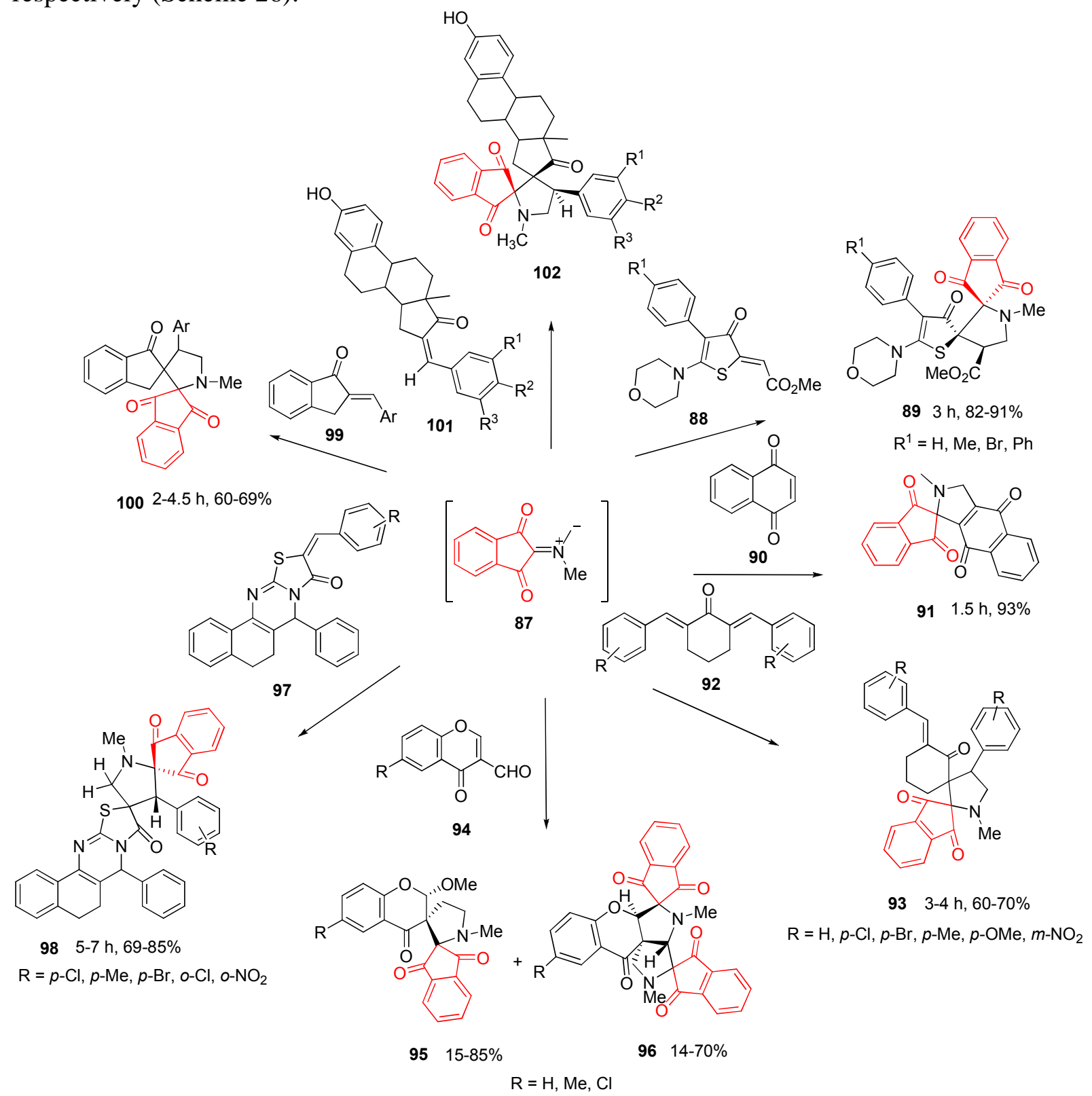

Scheme 26. Application of ninhydrin azomethine ylide in 1,3-dipolar cycloaddition reactions. 
Chromone-3-carbaldehydes 94 have been used as dipolarophiles in the one-pot synthesis of several dispirochromanopyrrolidines 95 and 96 as a racemic mixture in boiling alcohol (Scheme 26). ${ }^{193}$ In a one-pot cycloaddition reaction, the azomethine ylide 87 was reacted with $(E) 5 H-2-$ (arylmethylidene)-5-phenyl-6,7-dihydrothiazolo[2,3- $b]$ benzo[ $h]$ quinazolin-3(2H)-one $\quad 97 \quad$ in refluxing methanol to afford a series of novel dispiropyrrolidines $\mathbf{9 8}$ regioselectively (Scheme 26). ${ }^{194}$ A series of twelve dispiropyrrolidines 100 were synthesized using a [3+2]-cycloaddition reaction of azomethine ylides to appropriate dipolarophiles, 2-[(E)-1-arylmethylidene]-1-indanones 99 (Scheme 26). ${ }^{195}$ The synthesized compounds in this study were screened for their antimycobacterial activities, with four of them showing good activity with MIC of less than $1 \mu \mathrm{M}$.

The reaction of (Z)-16-arylmethylidene estrone derivatives 101 with 87 for the facile synthesis of hitherto unknown steroidal pyrrolidines $\mathbf{1 0 2}$ was described (Scheme 26). ${ }^{196}$

Raghunathan and co-workers investigated the reaction of $\beta$-nitrostyrene 103 with nonstabilized azomethine ylides that were generated from ninhydrin $\mathbf{1}$ and sarcosine $\mathbf{1 0 4} 4^{197}$ or proline $\mathbf{1 0 5},{ }^{198}$ to afford a series of spiroindan-nitro-pyrrolidines 106 and spiroindan-nitro-pyrrolizidines 107, respectively (Scheme 27). This method was later used by Chen and co-workers to prepare similar products. ${ }^{199-201}$ While the authors claimed that all the reactions proceeded with high regio- and stereoselectivity, it appears that at least the enantiomers of the products (106 and 107) should have formed during the reaction.

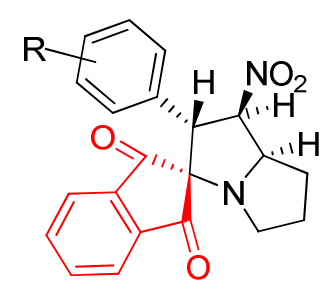

$107 \quad 78-83 \%$

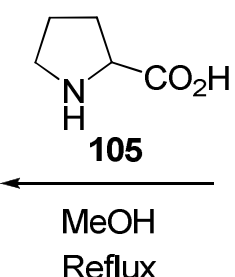

Reflux

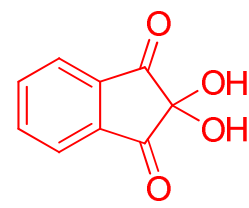

1

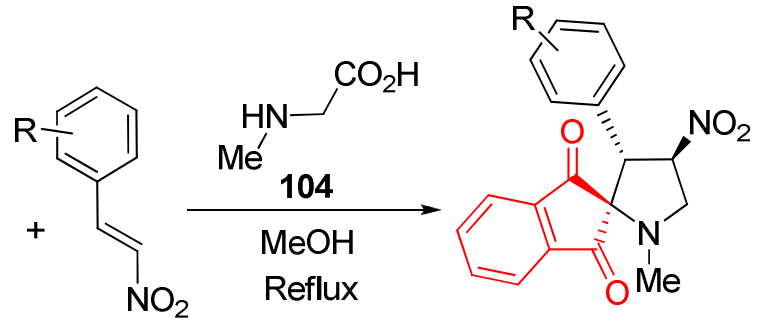

103

$$
\mathrm{R}=\mathrm{H}, p-\mathrm{Me}, p-\mathrm{OMe}, m-\mathrm{NO}_{2}, p-\mathrm{Cl}, o-\mathrm{Cl}
$$

$\mathrm{R}=\mathrm{H}, p-\mathrm{Me}, p-\mathrm{OMe}, m-\mathrm{NO}_{2}, p-\mathrm{Cl}, o-\mathrm{Cl}$

Scheme 27. Three-component synthesis of spiroindan-nitro-pyrrolidines and spiroindan-nitropyrrolizidines.

Some other dipolarophiles such as benzo[b]thiophene-1,1-dioxide, ${ }^{202} 3$-arylmethylidene-4chromanone, ${ }^{203}$ monoarylmethylidene cyclopentanones, ${ }^{204}$ 3-phenyl-5-isoxazolone, ${ }^{205}$ 9arylmethylidene fluorenes, ${ }^{206}$ and (E)-3-aryl-1-(thiophen-2-yl)prop-2-en-1-ones, ${ }^{207}$ were employed in the reaction with azomethine ylides to afford various spiro-pyrrolidines and pyrrolizidines 108113, respectively (Figure 2). 

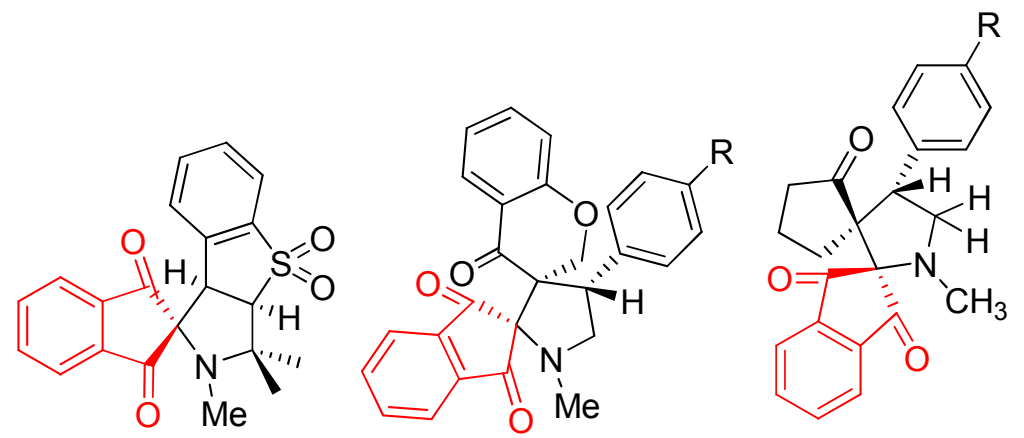

$10882 \%$

$10968-78 \%$

$11040-90 \%$<smiles>CN1C[C@@]2(C(=O)c3ccccc3C1=O)C(=O)[C@H]2/C(=N\O)c1ccccc1</smiles>

$11176 \%$

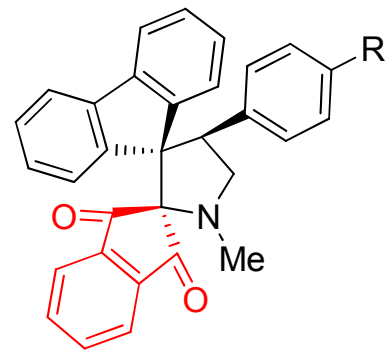

$11284-94 \%$<smiles>[R]c1ccc([C@@H]2C(=O)C(=O)[C@@]3(C4CCCN43)[C@@H]2C(=O)c2cccs2)cc1[R]</smiles>

$11380-98 \%$

Figure 2. Structure of various spiro-pyrrolidines and pyrrolizidines 108-113.

Three-component regio- and product-selective domino protocols to synthesis a racemic mixture of novel cage diazapenta- and hexacyclic ring systems $\mathbf{1 1 5}$ and $\mathbf{1 1 6}$ through a 1,3-dipole generationcycloaddition-annulation sequence were reported (Scheme 28). ${ }^{208}$ The same group discovered that these hexacyclic derivatives exhibited vital pharmacological properties, were considered useful to treat Alzheimer's disease. ${ }^{209}$ Later, application of different ionic liquids, such as 1,1,3,3tetramethylguanidine acetate $[\mathrm{TMG}][\mathrm{Ac}]^{210}$ and 1-butyl-3-methylimidazolium bromide $([\mathrm{BMIm}] \mathrm{Br})^{211}$ in this reaction was also investigated. [BMIm] Br was used in the four-component synthesis of spiropyrrolidines 118 through the 1,3-dipolar cycloaddition reaction involving 1methyl-3,5-bis[(E)-arylmethylidene]-tetrahydro-4(1H)-pyridinones 114, ninhydrin 1, sarcosine 104 and $o$-phenylenediamine 117 (Scheme 29). 


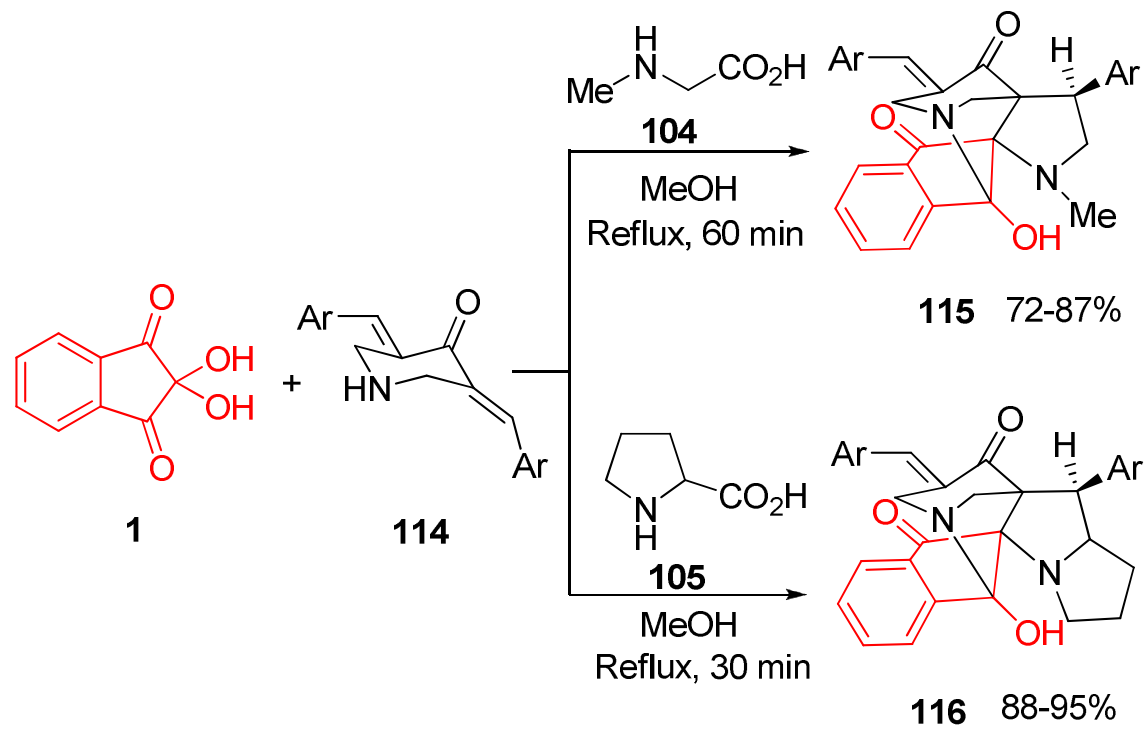

$\mathrm{Ar}=\mathrm{Ph}, 2-\mathrm{ClC}_{6} \mathrm{H}_{4}, 3-\mathrm{NO}_{2} \mathrm{C}_{6} \mathrm{H}_{4}, 4-\mathrm{MeC}_{6} \mathrm{H}_{4}$, 4- $\mathrm{ClC}_{6} \mathrm{H}_{4}, 4-\mathrm{BrC}_{6} \mathrm{H}_{4}, 4-\mathrm{FC}_{6} \mathrm{H}_{4}$

Scheme 28. Three-component regioselective synthesis of diazapenta- and hexacyclic ring systems.

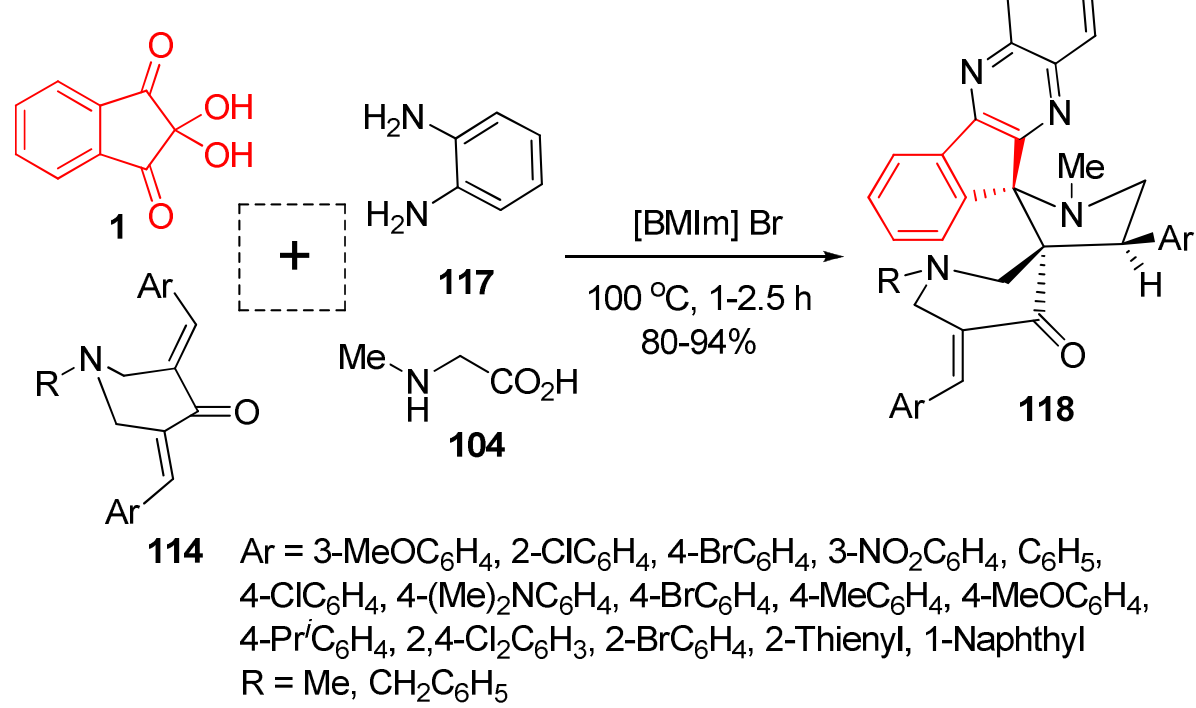

Scheme 29. Four-component synthesis of spiropyrrolidines.

Raghunathan and co-workers published a study on the one-pot synthesis of novel ferrocene grafted $N$-methylspiropyrrolidines $\mathbf{1 2 0}$ in good yields through a facile 1,3-dipolar cycloaddition reaction of various azomethine ylides, derived from ninhydrin 1 and sarcosine 104 with various ferrocene derivatives including 119 as dipolarophilic partners (Scheme 30). ${ }^{212}$ This group also reported a one-pot four-component synthesis of novel ferrocene embedded monospiro- 
indenoquinoxaline pyrrolizidines through 1,3-dipolar cycloaddition of azomethine ylide, generated from 1,2-phenylenediamine, ninhydrin, and L-proline, with various unusual ferrocene derived dipolarophiles. $^{213}$

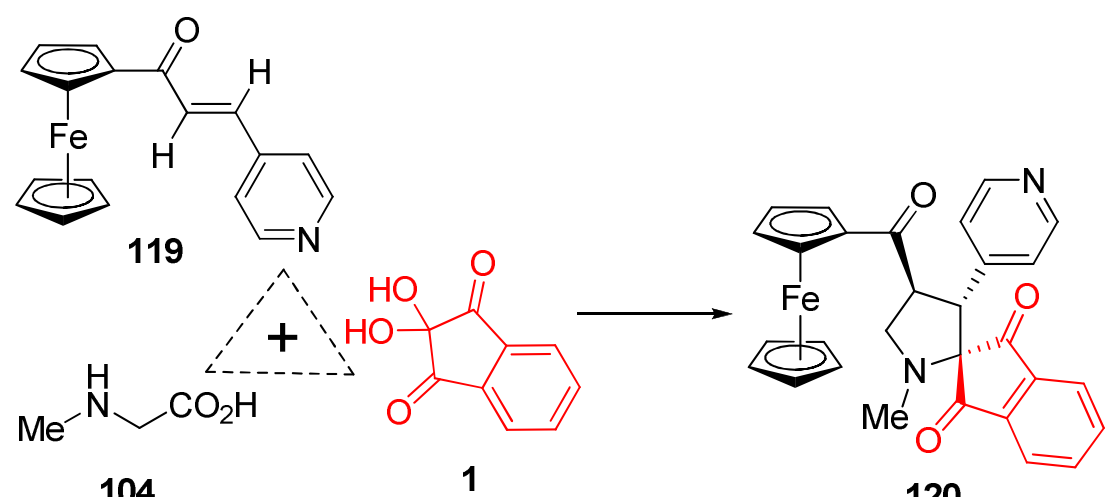

104

Method A: acetonitrile/reflux Method B: toluene/reflux
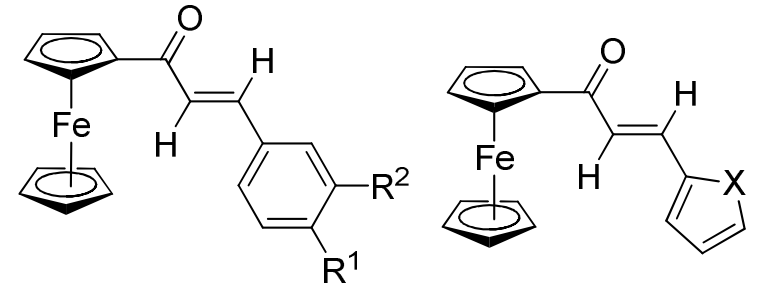

$\mathrm{R}^{1}=\mathrm{H}, \mathrm{OMe}, \mathrm{Cl}$

$\mathrm{X}=\mathrm{O}, \mathrm{S}$

$\mathrm{R}^{2}=\mathrm{NO}_{2}$, OMe
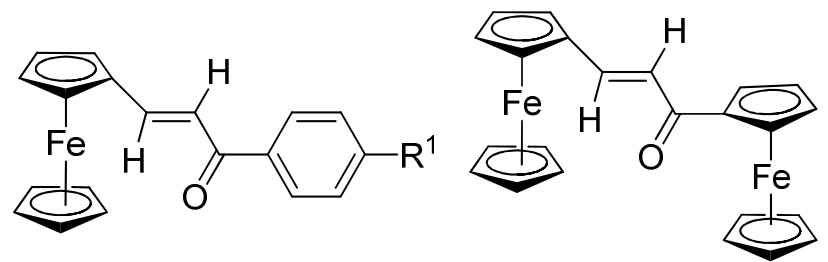

$\mathrm{R}^{1}=\mathrm{H}, \mathrm{OMe}$

Scheme 30. Three-component synthesis of novel ferrocene grafted $N$-methyl-spiropyrrolidines.

In a related study, an unusual ferrocene-derived Baylis-Hillman adduct $\mathbf{1 2 1}$ was used as a dipolarophile for the synthesis of novel ferrocene-derived heterocycles 122-123 (Scheme 31). ${ }^{214}$ In this reaction, the cycloadduct initially formed undergoes intramolecular cyclization to give furopyrrolidine $\mathbf{1 2 2}$ due to the proximity of the carbonyl group to the hydroxyl group. The synthesized cycloadducts were also evaluated for antimicrobial activities, and some compounds showed promising bioactivity against six human pathogens, as compared to reference compound tetracycline. ${ }^{215}$ The synthesis of novel ferrocenyl oxindoles was successfully achieved, and a series of novel dispiroheterocyclic system was synthesized via the cycloaddition of azomethine ylides with the newly synthesized ferrocenyl oxindoles. ${ }^{216}$ 
<smiles>C=C(C(=O)OC)C(O)c1ccccc1Oc1ccccc1</smiles>

121

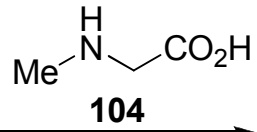

$\mathrm{MeOH}$, reflux 12 h, $80 \%$<smiles>O=C1c2ccccc2C(=O)C1(O)O</smiles>

1
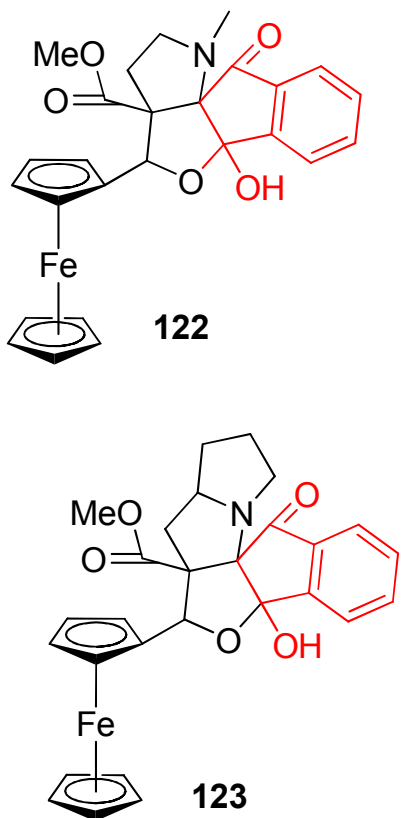

Scheme 31. Three-component synthesis of ferrocene-derived heterocycles from ninhydrin, sarcosine/proline, and ferrocene-derived Baylis-Hillman adduct.

Microwave-assisted synthesis of spiropyrrolidines 128-131 was accomplished using the alkene unit of Baylis-Hillman adducts of ninhydrin 124 with sarcosine 104 and various activated ketones 125, 126, 1, and 127 through a 1,3-dipolar cycloaddition reaction. Application of proline in these reactions was also investigated, and the products were obtained in excellent yields with high regioselectivity in a short time (Scheme 32). ${ }^{217}$ Methyl 2-(2,3-dihydro-2-hydroxy-1,3-dioxo- $1 H$ inden-2-yl) acrylate $\mathbf{1 2 4}$ was synthesized via the Baylis-Hillman reaction of ninhydrin $\mathbf{1}$ and methyl acrylate and utilized as a dipolarophile in this reaction. In a related study, the same strategy was followed for the synthesis of a racemic mixture of products. ${ }^{218}$ Application of a Baylis-Hillman adduct of heterocyclic aldehydes with azomethine ylides to afford penta- and tetracyclic systems in the presence of montmorillonite K10 clay was also investigated. ${ }^{219}$ 
<smiles>O=C1Nc2ccccc2C1=O</smiles>

125

Method A: $3 \mathrm{~h}, 51 \%$

Method B: 20 min, 62\%

Method C: 5 min, $84 \%$<smiles>O=C1c2ccccc2-c2nc3ccccc3nc21</smiles>

Method A: $5.5 \mathrm{~h}, 30 \%$

Method B: 30 min, 40\%

Method C: $10 \mathrm{~min}, 70 \%$<smiles>O=C1c2ccccc2C(=O)C1(O)O</smiles>

Method A: 2 h, 58\%

Method B: 10 min, 70\%

Method C: 2 min, $88 \%$<smiles>O=C1c2cccc3cccc1c3c2=O</smiles>

127

Method A: 2.5 h, $40 \%$

Method B: 25 min, 65\%

Method C: $3 \mathrm{~min}, 78 \%$

Method A: conventional MeOH/ Reflux.

Method B: $\mathrm{MeOH} / \mathrm{MW}$.

Method C: K-10 Montmorillonite clay/MW.<smiles></smiles>

28<smiles>COC(=O)C1(C2(O)C(=O)c3ccccc3C2=O)CC2(C=CC2=N)c2ccccc2C1=O</smiles><smiles>C=NNc1ccccc1N=C</smiles>

131

Scheme 32. Microwave-assisted synthesis of spiropyrrolidines.

The synthesis of a racemic mixture of novel dispiroheterocycles containing a bicyclo[2.2.1] heptane ring system 135 through sequential [3+2] and [4+2] cycloadditions was described by Raghunathan's group (Scheme 33). ${ }^{220}$ 
<smiles>[X]c1ccccc1C(=O)/C(C)=C(\C)c1ccco1</smiles><smiles>O=C1c2ccccc2C(=O)C1(O)O</smiles>

1
132

\section{2}<smiles>C1CCC1</smiles>

$\sqrt{2}$<smiles>CO[R]([O-])([O-])O</smiles>

104

$$
\mathrm{X}=\mathrm{O}, \mathrm{CH}_{2}
$$
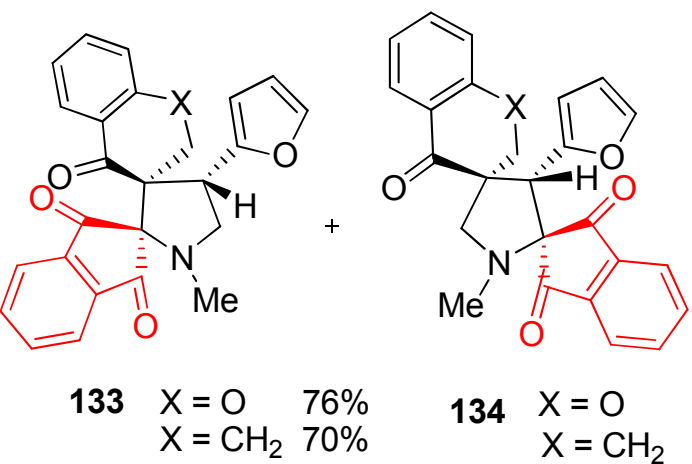

$134 X=O$

$\mathrm{X}=\mathrm{CH}_{2}$

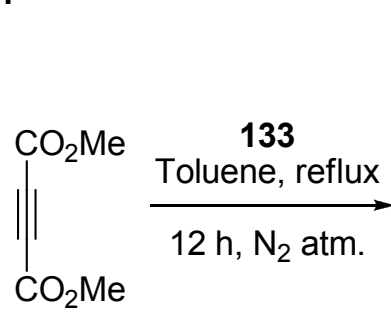

41

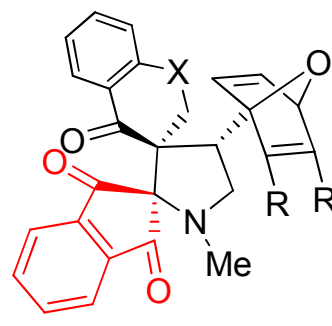

135
$\mathrm{X}=\mathrm{O}, \mathrm{R}=\mathrm{CO}_{2} \mathrm{Me} \quad 55 \%$

$\mathrm{X}=\mathrm{CH}_{2}, \mathrm{R}=\mathrm{CO}_{2} \mathrm{Me} 53 \%$

Scheme 33. 1,3-Dipolar cycloaddition reaction followed by intermolecular Diels-Alder cycloaddition for the synthesis of bicyclo[2.2.1] heptane ring system.

Scheme 34 illustrates the construction of a variety of norbornane-fused novel spiro-1,3indanedione-pyrrolidine motifs. The cycloaddition reactions of azomethine ylide generated from ninhydrin and sarcosine with various norbornenes furnished the respective racemate norbornanefused spiro-1,3-indandionolylpyrrolidines $\mathbf{1 3 7 - 1 4 0}$ as single diastereomers. ${ }^{221} \mathrm{~N}, N^{\prime}$-bis(5norbornene-2,3-dicarboximide) 141 and $N, N^{\prime}$-bis(7-oxa-5-norbornene-2,3- dicarbox-imide) 142 were later used in this reaction to form several other novel products. ${ }^{22}$ 

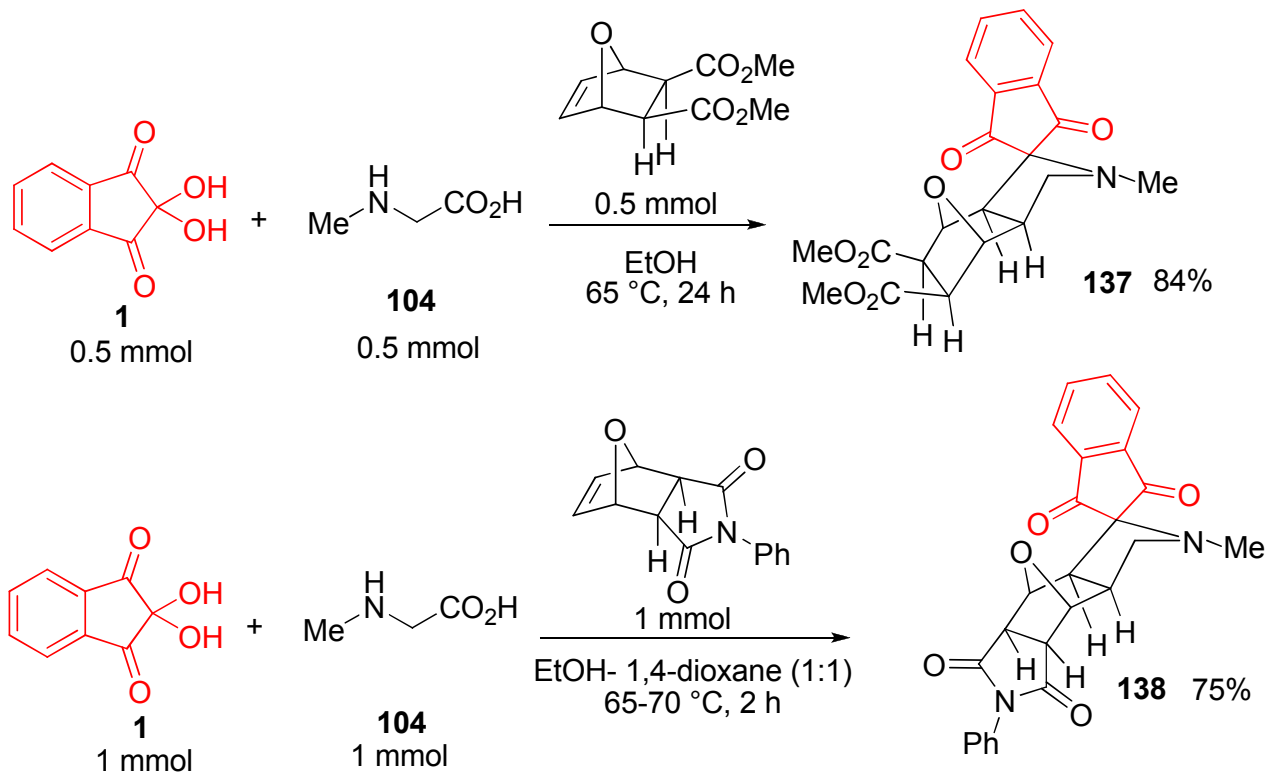

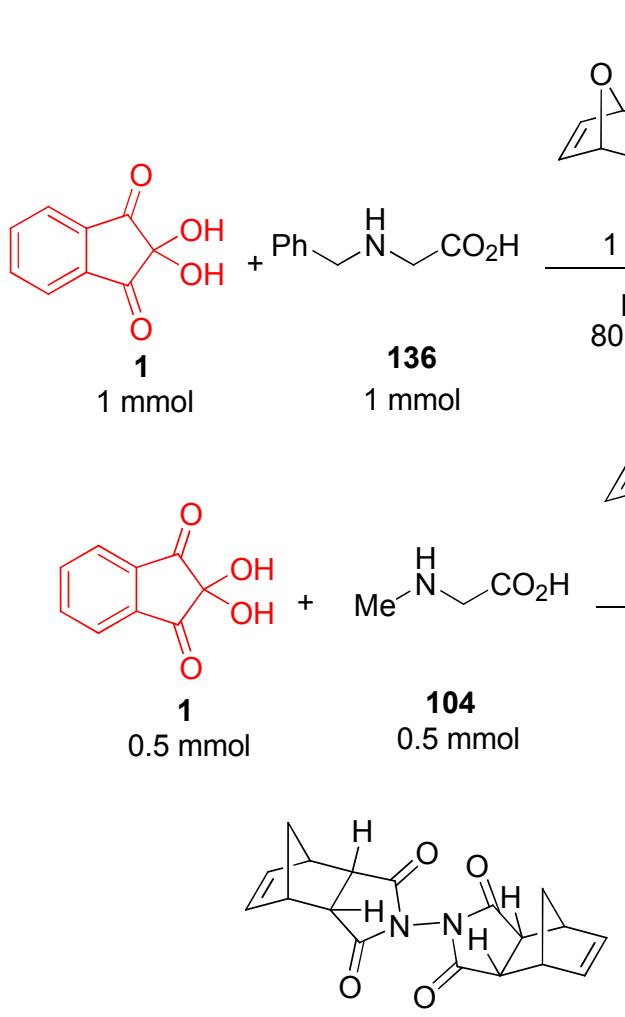

141
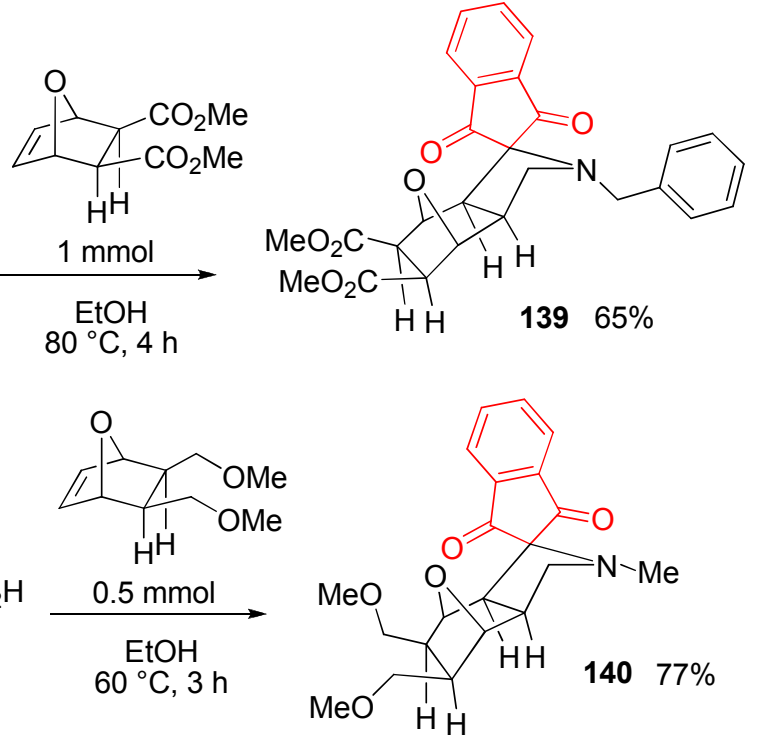

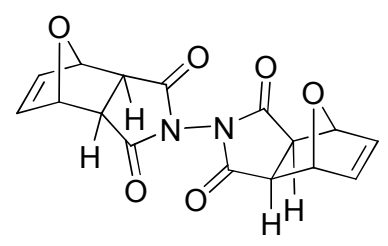

142

Scheme 34. Three-component synthesis of norbornane-fused spiro-1,3-indandionolylpyrrolidine motifs.

The three-component reaction of azomethine ylide, generated from sarcosine and ninhydrin with dipolarophiles to yield a series of novel dispiroindano cycloheptan/octanone pyrrolidines in good yields is a variation on this theme. ${ }^{223}$ Cyclic secondary $\alpha$-amino acids react regiospecifically with 
ninhydrin to give stable azomethine ylides. Proline $\mathbf{1 0 5}^{224}$ and hydroxyproline $\mathbf{1 0 5 b}$ therefore react with ninhydrin to give the stable azomethine ylides 143a and 143b. As expected, 143a and 143b undergo a wide range of cycloaddition reactions at room temperature with suitable dipolarophiles, e.g. 143a reacts with diphenyl fumarate to give $\mathbf{1 4 4 a}$ (71\%), and $\mathbf{1 4 3 b}$ reacts with methyl acrylate to form 144b $(70 \%)$ as a racemic mixture. In contrast to proline, ninhydrin reacts with $N$ methylglycine to give the oxazolidine $\mathbf{1 4 5}$ derived from cyclisation of the intermediate azomethine ylide (Scheme 35). ${ }^{225}$ Glycine amide and alanine amide also react with ninhydrin to form the polycyclic compounds 146.

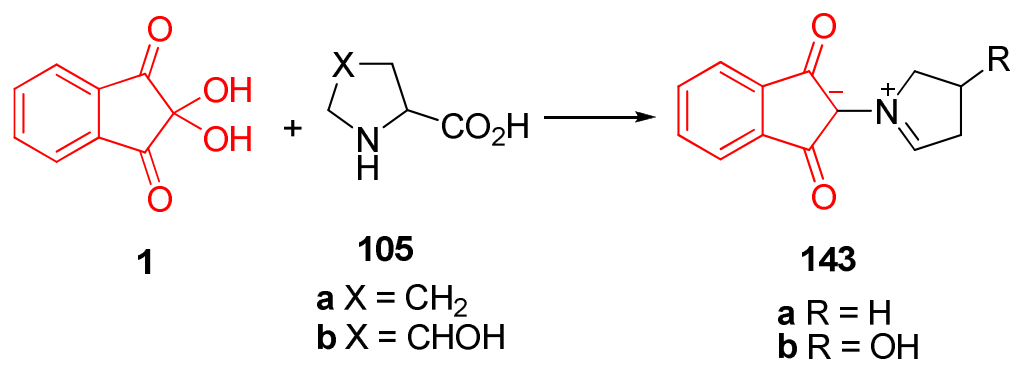

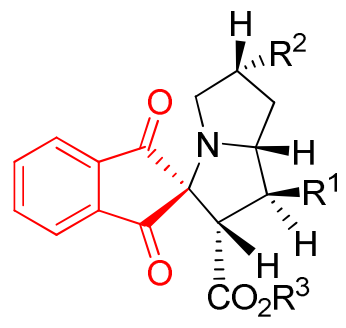

144<smiles>CN1COC2=C1C(=O)c1ccccc12</smiles>

145<smiles>[R]c1nc2c(nc1O)-c1ccccc1C2=O</smiles>

146

$\mathrm{R}=\mathrm{H}, \mathrm{Me}$

a $\mathrm{R}^{1}=\mathrm{CO}_{2} \mathrm{Ph}, \mathrm{R}^{2}=\mathrm{H}, \mathrm{R}^{3}=\mathrm{Ph}$

b $\mathrm{R}^{1}=\mathrm{H}, \mathrm{R}^{2}=\mathrm{OH}, \mathrm{R}^{3}=\mathrm{Me}$

Scheme 35. Reaction of secondary $\alpha$-amino acids with ninhydrin to form polycyclic compounds.

Efficient four-component and stereoselective synthesis of new spiro[indeno[1,2- $b$ ]quinoxaline11,2'-pyrrolidine] derivatives $\mathbf{1 4 8}$ via 1,3-dipolar cycloaddition reactions of ninhydrin $\mathbf{1}$, phenylenediamine 117, sarcosine 104, and chalcones 147 was described by Jadidi and co-workers (Scheme 36). ${ }^{227}$ The regiochemistry and stereochemistry of resultant cycloadducts have been determined by several 2D NMR spectroscopic techniques and X-ray single crystal diffraction. Mohammadizadeh and Firoozi employed proline $\mathbf{1 0 5}$ in this reaction for stereoselective synthesis of some spiro[indeno[1,2-b]quinoxaline-11,3'-pyrrolizidine] derivatives 149 in very good yields (Scheme 36). ${ }^{228}$ High diastereomeric excess of reaction was deduced on the basis of ${ }^{1} \mathrm{H}$ NMR spectra through which no other diastereomers could be detected. It is noteworthy that adducts $\mathbf{1 4 9}$ have three or four (including nitrogen) stereogenic centers, but their synthesis affords only one diastereomer, due to the fixed configuration of corresponding dipole and the structure of transition state, as was later mentioned by Grigg and his co-workers in a series of extensive studies. ${ }^{229-230}$ 


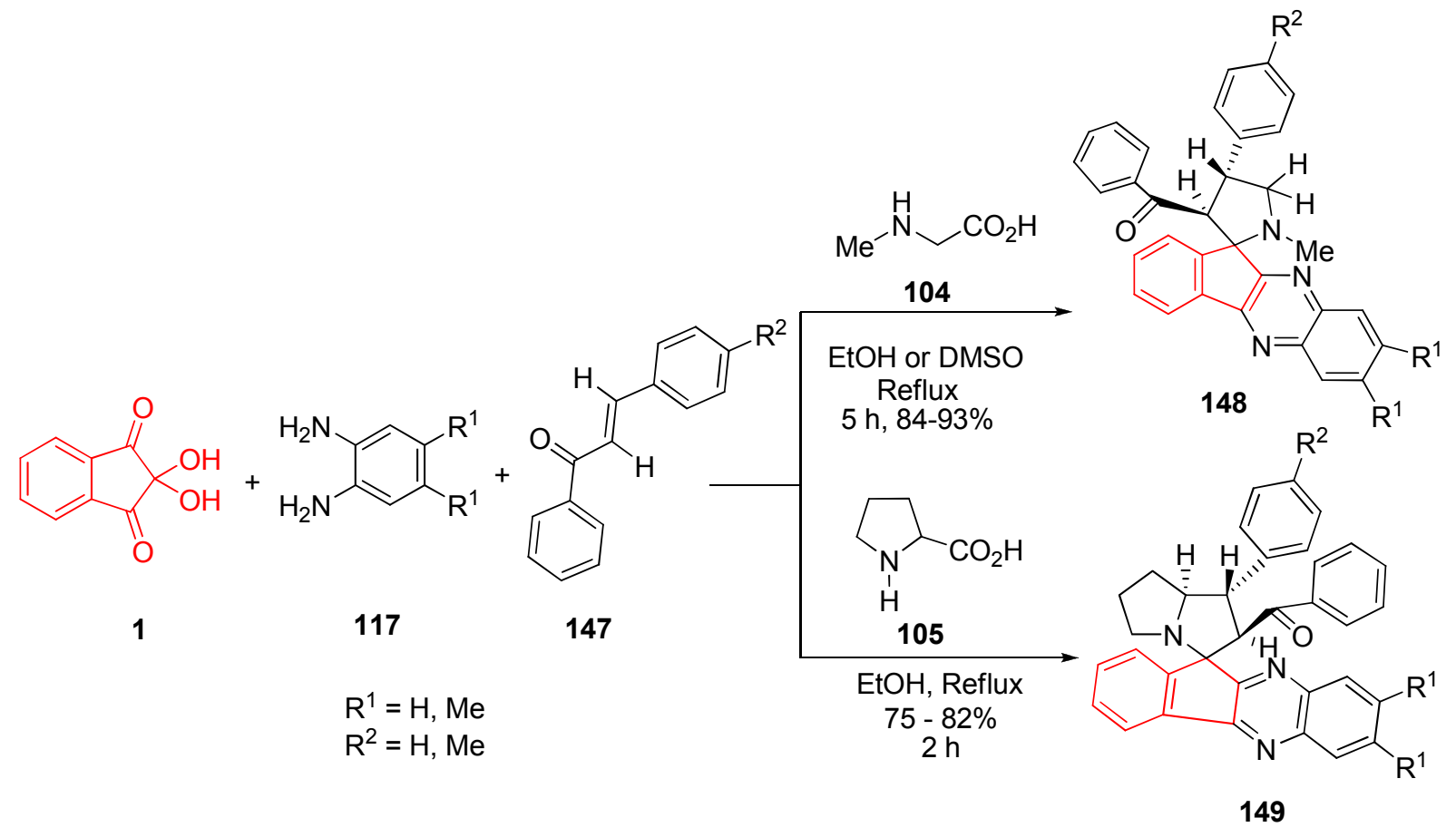

Scheme 36. Four-component synthesis of indeno[1,2-b]quinoxaline derivatives.

Replacing chalcones 147 with $N$-aryl maleimides 150 in the above reaction afforded some new spiro pyrrolizidines 151 via 1,3-dipolar cycloadditions of azomethine ylides under microwave irradiation (Scheme 37). ${ }^{231}$

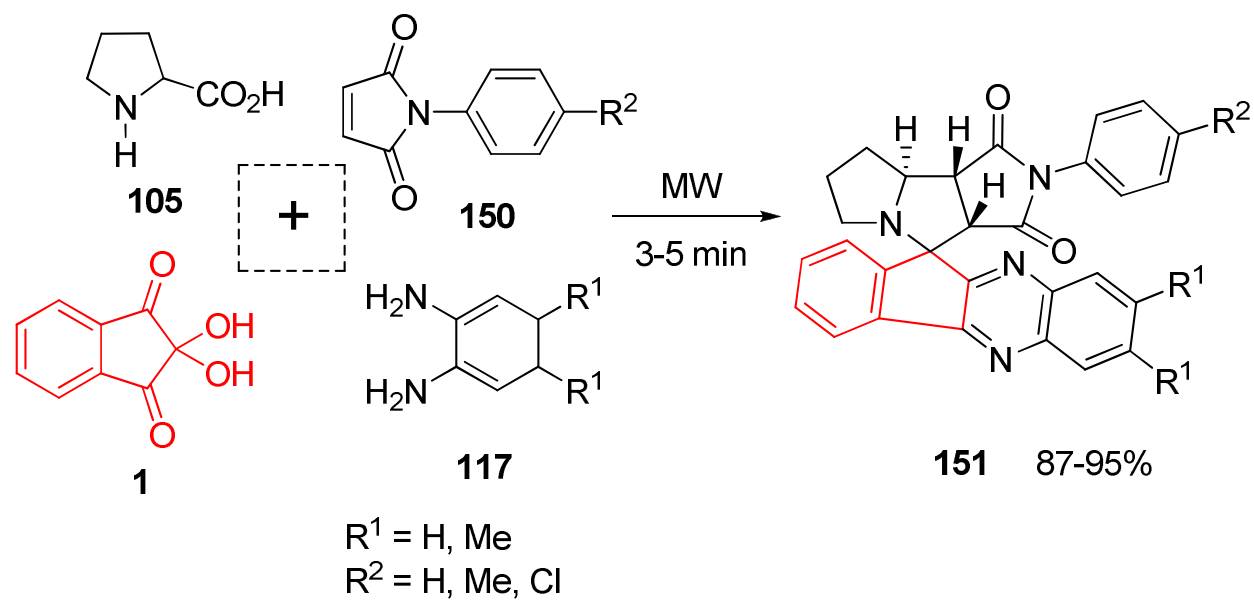

Scheme 37. Microwave assisted four-component synthesis of spiro pyrrolizidines.

The one-pot four-component reaction of ninhydrin 1 , phenylenediamine 117 , proline 105 , and acrylic acid derivative $\mathbf{1 5 2}$ in ethanol to afford a racemic mixture of alkyl spiro[indeno[1,2- 
b]quinoxaline-11,3'-pyrrolizidine]-2'-carboxylates 153 was reported by Mohammadizadeh and coworkers (Scheme 38$){ }^{232}$

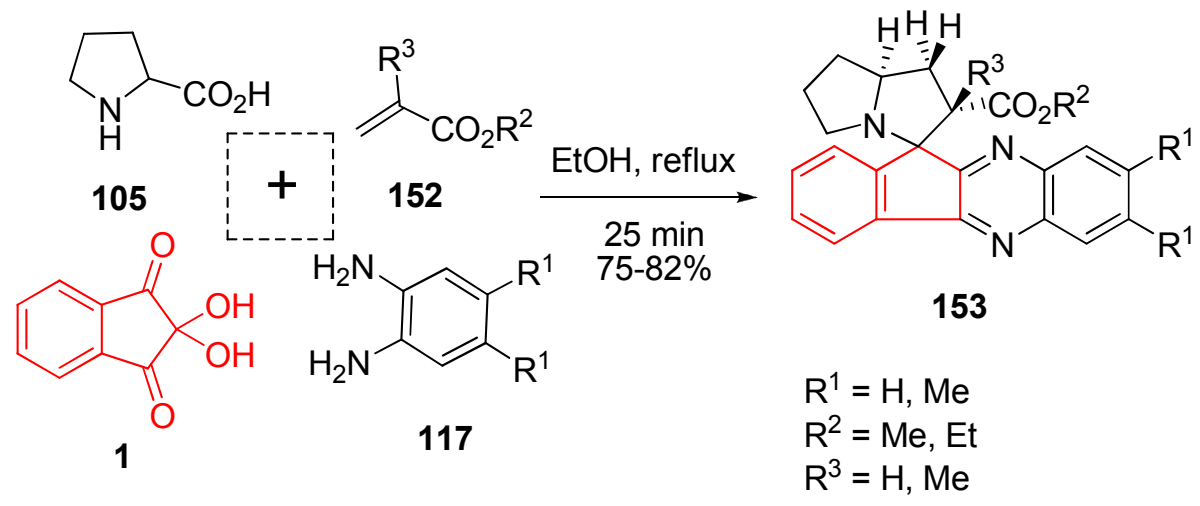

Scheme 38. Four-component synthesis of [indeno[1,2-b]quinoxaline-11,3'-pyrrolizine]-2'carboxylates from ninhydrin, phenylenediamine, proline, and acrylic acid derivative.

Preparation of racemic spirocyclic pyrrolidine analogues $\mathbf{1 5 5}$ via the reaction of ninhydrin $\mathbf{1}$, phenylglycine 154 and substituted maleimides 150 was reported by Grigg's group (Scheme 39). ${ }^{233}$ The compounds synthesized were later screened for their antibacterial activities, which showed potent activity against E. faecalis and $S$. aureus PheRSs with high selectivity over the human enzyme being discovered. ${ }^{234}$ The same group also studied the intervention of 1,3-dipolar species in the decarboxylative transamination of $\alpha$-amino acids by trapping with a range of dipolarophiles. ${ }^{235}$

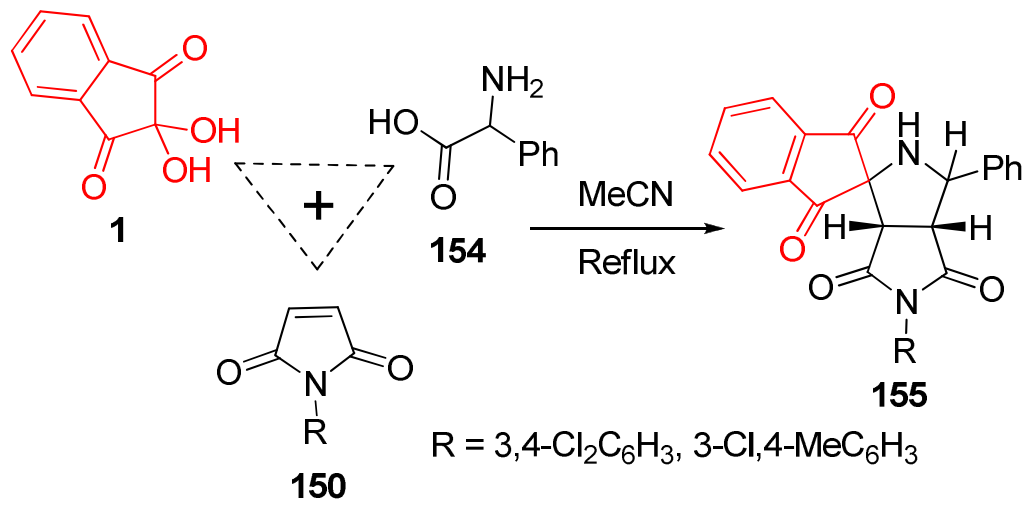

Scheme 39. Three-component synthesis of spirocyclic pyrrolidine analogues.

When a mixture of ninhydrin 1, 4-methoxybenzylamine 156 and $N$-methylmaleimide $\mathbf{1 5 0}$ in acetonitrile is heated, the reaction furnishes a racemic mixture of endo- and exo-cycloadducts 157a $(65 \%)$ and $\mathbf{1 5 7 b}(8 \%)$ respectively, with a combined yield of $73 \%$ (Scheme 40$).{ }^{236}$ 


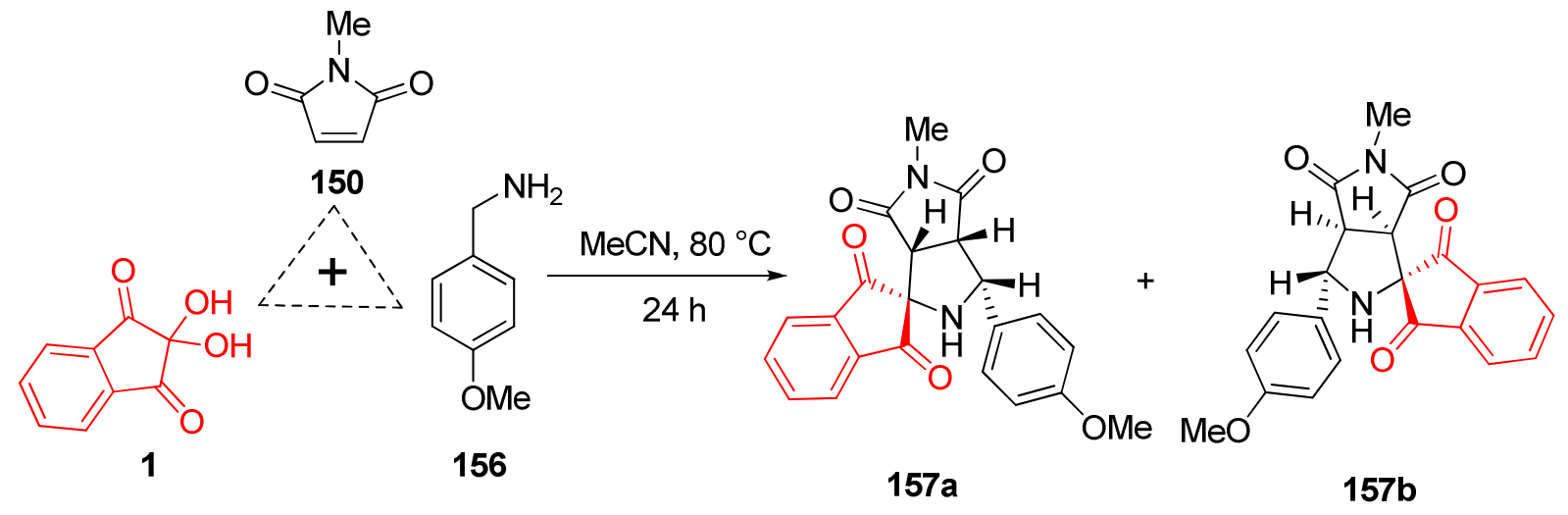

Scheme 40. Three-component synthesis of a mixture of endo- and exo-cycloadducts from ninhydrin, 4-methoxybenzylamine, and $N$-methylmaleimide.

Application of amino acid $\mathbf{1 5 8}$ in this reaction was also investigated (Scheme 41). ${ }^{237}$ Ninhydrin $\mathbf{1}, \mathbf{1 5 8}$, and $N$-phenylmaleimide 150 react giving a single racemic product whose stereochemistry was assigned on the basis of NOE experiments. The NMR spectrum of the reaction mixture revealed no sign of cyclopropyl ring opening products.

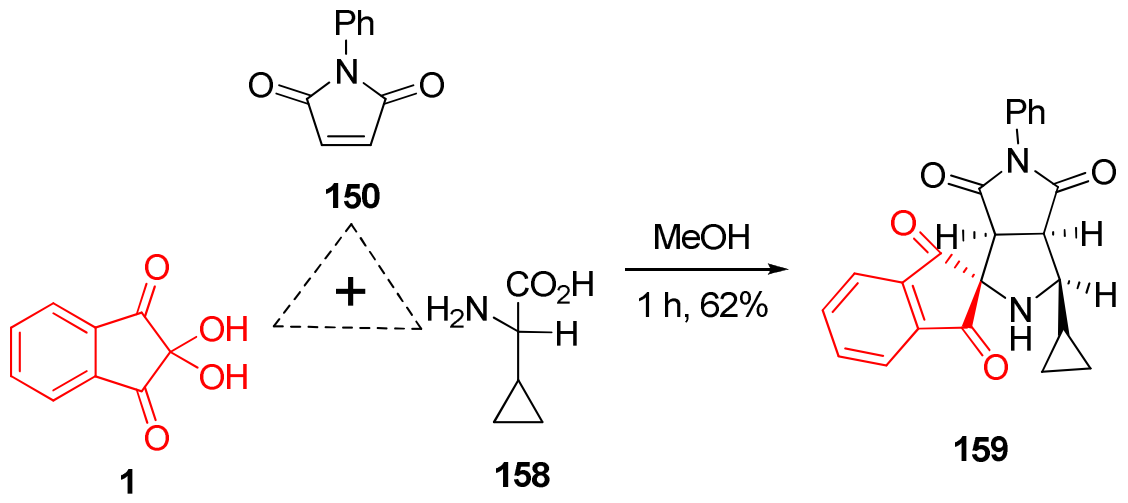

Scheme 41. Three-component reaction of ninhydrin, amino acids, and $N$-phenylmaleimide reported by Grigg.

(E)-2-oxoindolin-3-ylideneacetophenones 160 were used in a one-pot, three-component 1,3dipolar cycloaddition reaction with azomethine ylides to give the corresponding products $\mathbf{1 6 1}$ as a racemic mixture (Scheme 42). ${ }^{238}$ High regioselectivity was achieved for the reaction under ultrasonication conditions and in the presence of silica as a catalyst. Thereafter, the same group used dipolarophile 160 in the regioselective cycloaddition reaction with the azomethine ylide for the synthesis of dispiro[oxindole/indeno[1,2-b]quinoxaline] pyrrolidine ring systems as a racemic mixture. ${ }^{239}$ The ylide was generated from ninhydrin 1, 1,2-phenylenediamine 117, and sarcosine $\mathbf{1 0 4}$ by the decarboxylative route. 


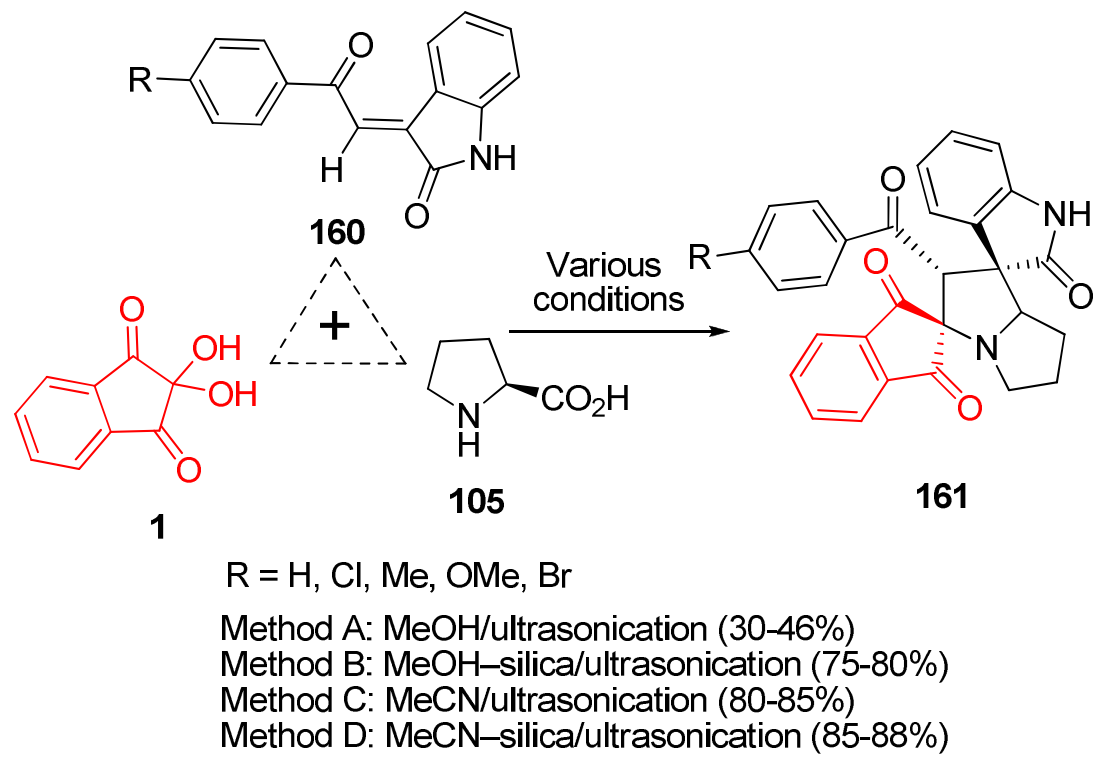

Scheme 42. Three-component 1,3-dipolar cycloaddition reaction reported by Raghunathan.

Three-component reaction of carbamate dipolarophile 160 with sarcosine 104 and ninhydrin 1 was carried out by heating a mixture of equimolar amounts of the reactants in boiling methanol, and the racemic spiro product $\mathbf{1 6 2}$ was isolated as a result of syn,endo addition of the dipolarophile to 1,3-dipole (Scheme 43). ${ }^{240}$

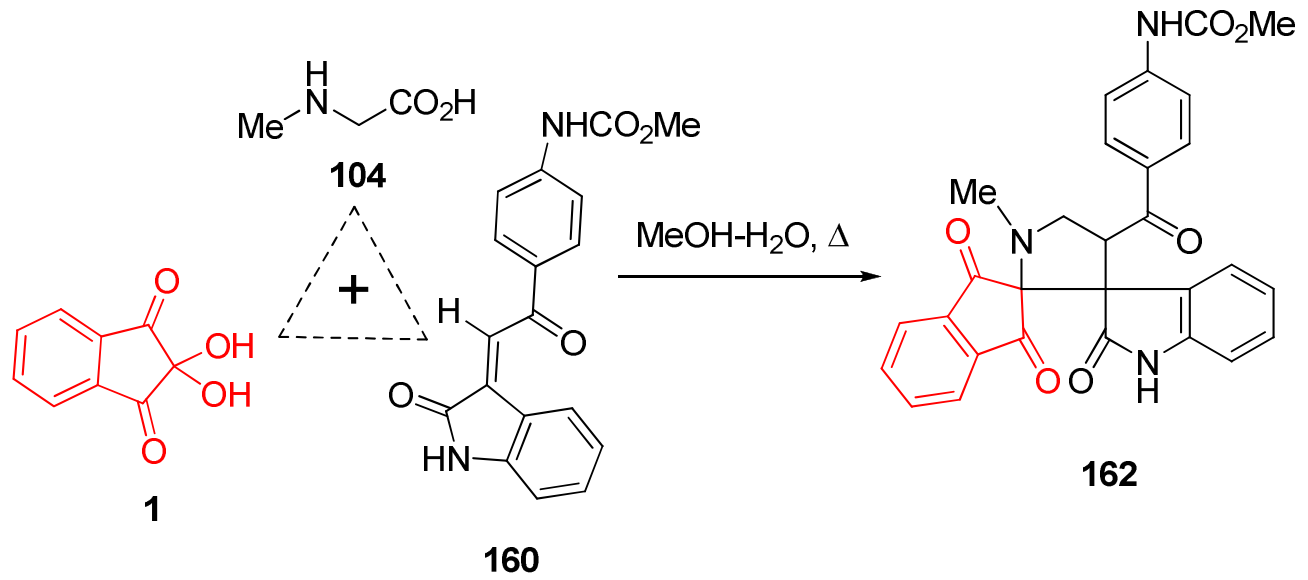

Scheme 43. Three-component synthesis of tetrahydrodispiro[indane-2,2'-pyrrolidine-3',3"- indol]4'-yl)carbonyl]phenylcarbamate.

$\mathrm{H}_{4}\left[\mathrm{Si}\left(\mathrm{W}_{3} \mathrm{O}_{10}\right)_{3}\right]$ as an efficient catalyst was used in the 1,3-dipolar cycloaddition reaction of azomethine ylides for the four-component, one-pot synthesis of dispiroindeno-quinoxaline pyrrolizidines 164 as a racemic mixture (Scheme 44). ${ }^{241}$ Different dipolarophiles including (E)-2arylmethylidenetetrahydronaphthalen-1-ones 165, (E)-3-arylmethylidene-4-chromanones 166 and 
(E)-2-oxoindolin-3-ylideneacetophenones 160 were used in this reaction. The application of solidsupport catalyst $\mathrm{TiO}_{2}$ for the synthesis of these systems was also investigated by the same group. ${ }^{242}$

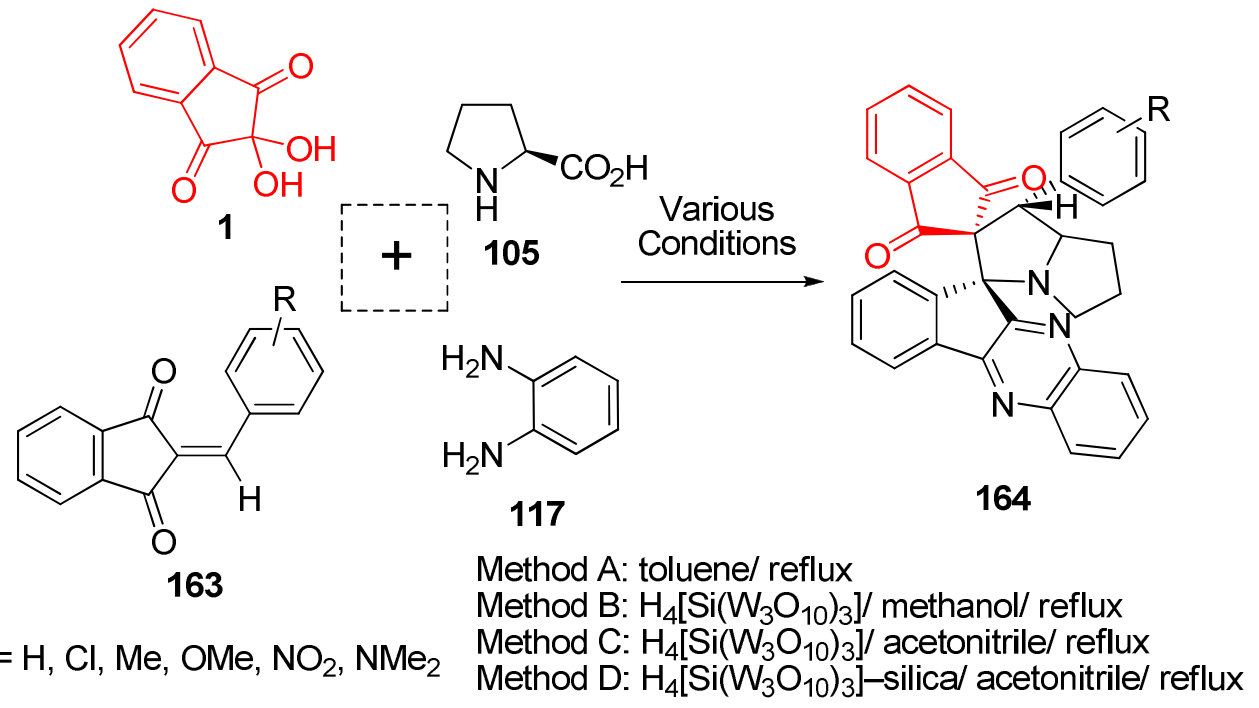

$$
\mathrm{R}=\mathrm{H}, \mathrm{Cl}, \mathrm{Me}, \mathrm{OMe}, \mathrm{NO}_{2}, \mathrm{NMe}_{2} \quad \begin{aligned}
& \text { Method } \mathrm{C}: \mathrm{H}_{4}\left[\mathrm{Si}\left(\mathrm{W}_{3} \mathrm{O}_{10}\right)_{3}\right] / \text { acetonitrile/ reflux } \\
& \text { Method } \mathrm{D}: \mathrm{H}_{4}\left[\mathrm{Si}\left(\mathrm{W}_{3} \mathrm{O}_{10}\right)_{3}\right]-\text { silica/ acetonitrile/ reflux }
\end{aligned}
$$<smiles>[R]c1ccc(/C=C2\CCc3ccccc3C2=O)cc1</smiles>

165<smiles>[R]c1ccc(/C=C2\COc3ccccc3C2=O)cc1</smiles>

166<smiles>[R]c1ccc(C(=O)/C=C2/C(=O)Nc3ccccc32)cc1</smiles>

160

$\mathrm{R}=\mathrm{H}, \mathrm{Cl}, \mathrm{Me}, \mathrm{OMe} \quad \mathrm{R}=\mathrm{H}, \mathrm{Cl}, \mathrm{Me}, \mathrm{OMe}, \mathrm{NMe}_{2} \quad \mathrm{R}=\mathrm{H}, \mathrm{Cl}, \mathrm{Me}, \mathrm{OMe}, \mathrm{Br}$

Scheme 44. $\mathrm{H}_{4}\left[\mathrm{Si}\left(\mathrm{W}_{3} \mathrm{O}_{10}\right)_{3}\right]$ catalyzed four-component synthesis of dispiroindeno-quinoxaline pyrrolizidines.

Regioselective synthesis of dispiropyrrolidine derivatives 168 isolated as a racemic mixture was carried out by reaction of ninhydrin 1 with sarcosine 104 and (E)-2-arylmethylidene-1-oxocarbazole 167 under three different conditions: a. refluxing in methanol, b. reacting in microwave irradiation with K-10 Montimorillonite clay, and c. reacting under microwave irradiation under neat condition (Scheme 45). ${ }^{243}$ Methods B and C gave better yields compared to Method A (see Scheme 45). 


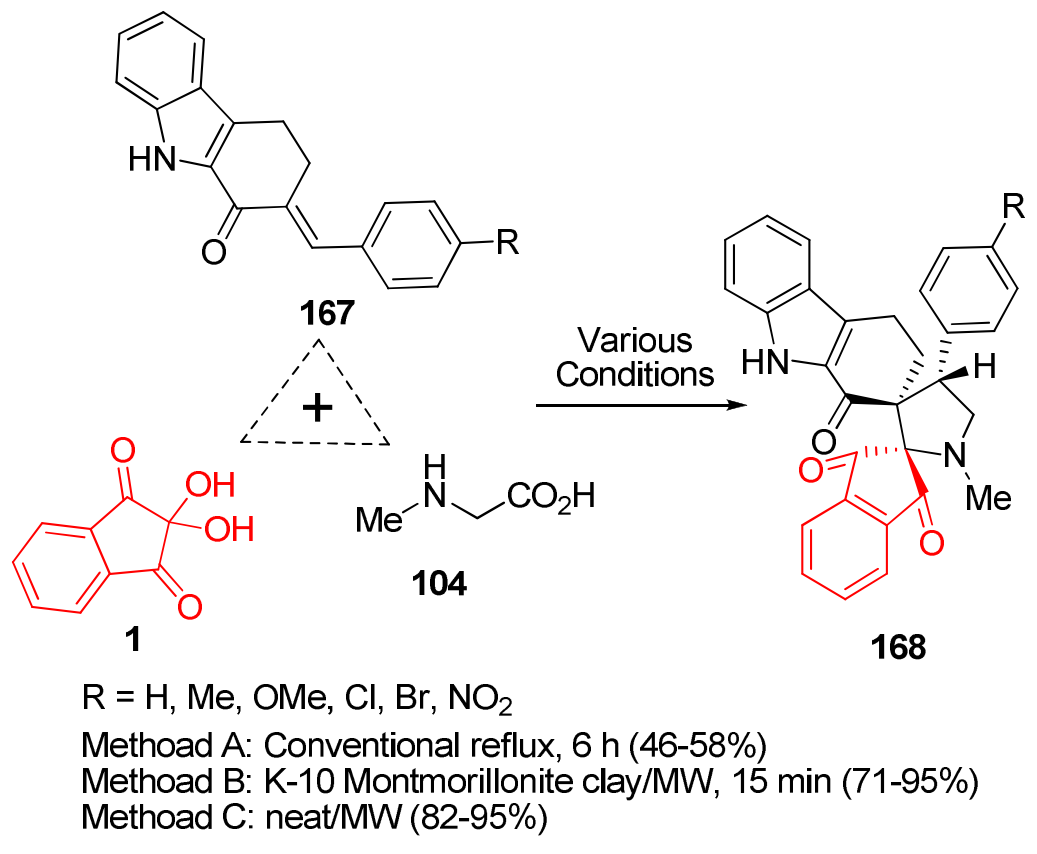

Scheme 45. Three-component synthesis of dispiropyrrolidine derivatives.

Compound 169 was isolated from the reaction of ninhydrin and $N$-methylacetamide. Subsequent catalytic hydrogenation and hydride reduction of $\mathbf{1 6 9}$ afford a variety of substituted derivatives (Scheme 46). ${ }^{244}$

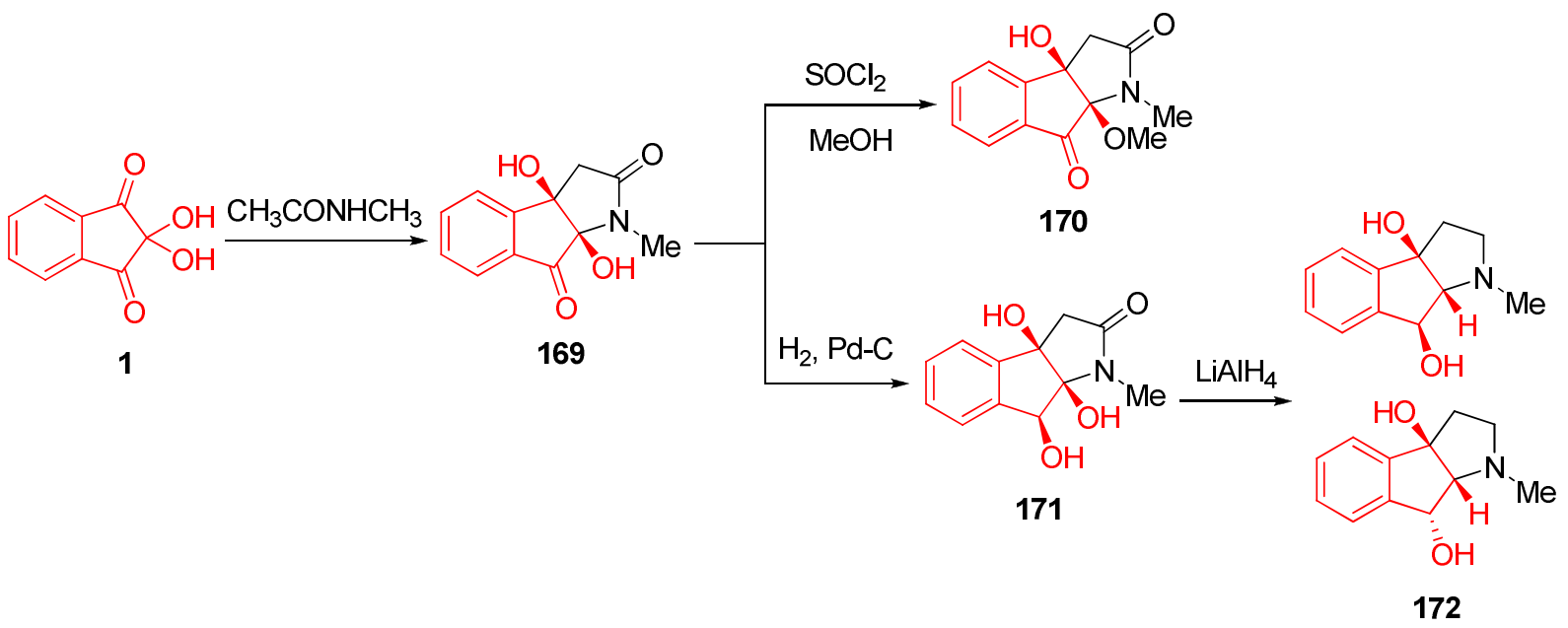

Scheme 46. Reaction of ninhydrin and $N$-methylacetamides.

A facile one-pot synthesis of a series of novel spiropyrrolidines/pyrrolizidines $\mathbf{1 7 6}$ and $\mathbf{1 7 7}$ containing a $\beta$-lactam moeity was accomplished through the 1,3-dipolar cycloaddition reaction of alkenyl esters 175. The latter was derived from the $\beta$-lactam aldehyde 173, and reacted with the 
dipolar azomethine ylide, derived from ninhydrin $\mathbf{1}$ and secondary amino acids $\mathbf{1 0 4}$ and $\mathbf{1 0 5}$ (Scheme 47). ${ }^{188}$<smiles>[R]C1C(=O)N(c2ccc(OC)cc2)[C@@H]1C=O</smiles>

$$
\mathrm{R}=\mathrm{OPh}, \mathrm{Ph}
$$<smiles>[R]C1C(=O)N(c2ccc(OC)cc2)[C@H]1/C=C/C(=O)OCC</smiles>

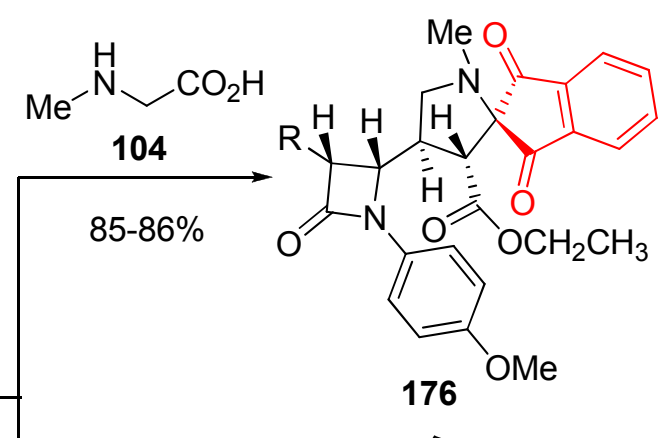

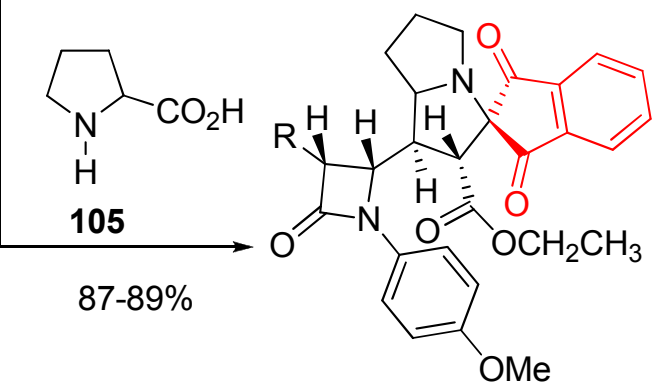

Scheme 47. One-pot three-component synthesis of novel spiropyrrolidines/pyrrolizidines.

A five-component regioselective reaction employing ninhydrin 1, 1,2-phenylenediamine 117, sarcosine 104, active methylene compounds, and aldehydes yielded the spiro-pyrrolidines 178 (Scheme 48). ${ }^{245}$ This reaction proceeds through a Knoevenagel condensation/1,3-dipolar cycloaddition sequence of in situ generated azomethine ylides and olefinic dipolarophiles. 


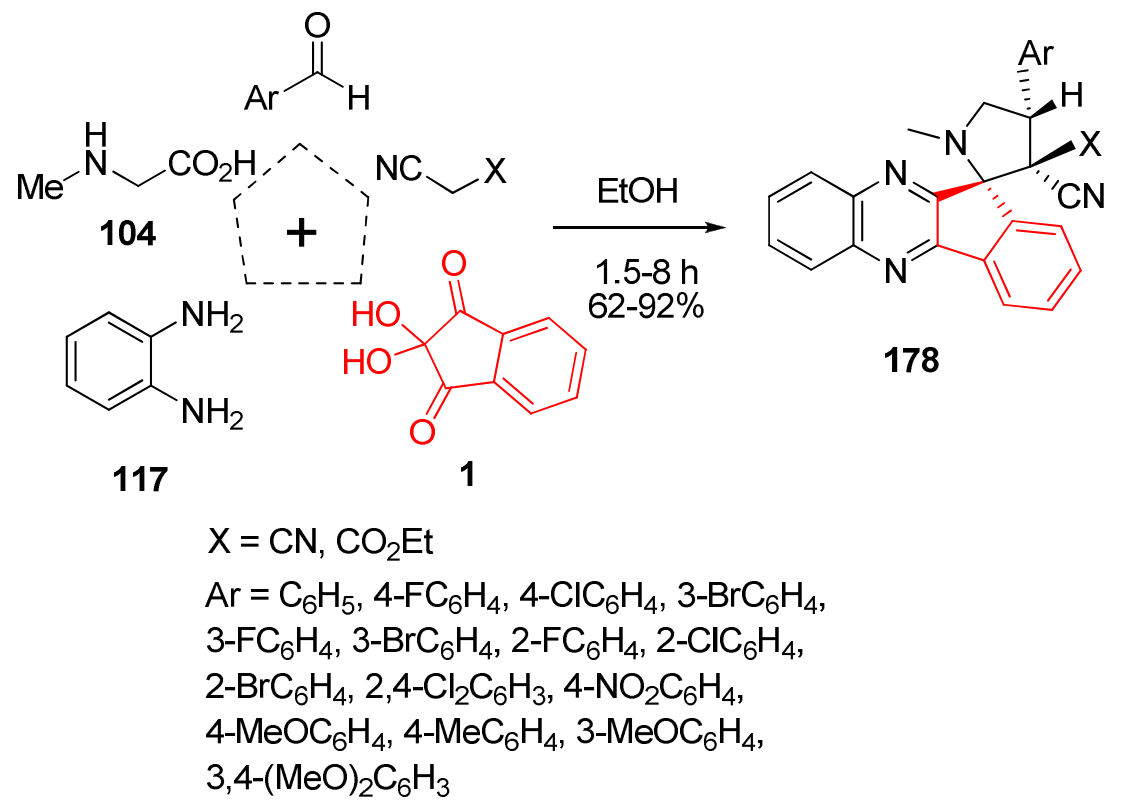

Scheme 48. Five-component regioselective synthesis of spiro-pyrrolidines.

Ninhydrin in reaction with 2-nitromethylenepyrrolidine 179 gives the cyclized product 180 in a double nucleophilic addition. The reaction proceeds regio- and diastereoselectively in high yield (Scheme 49). ${ }^{246}$ The cis configuration of the hydroxy groups was confirmed by NMR (both -OH groups are involved in intramolecular H-bond).

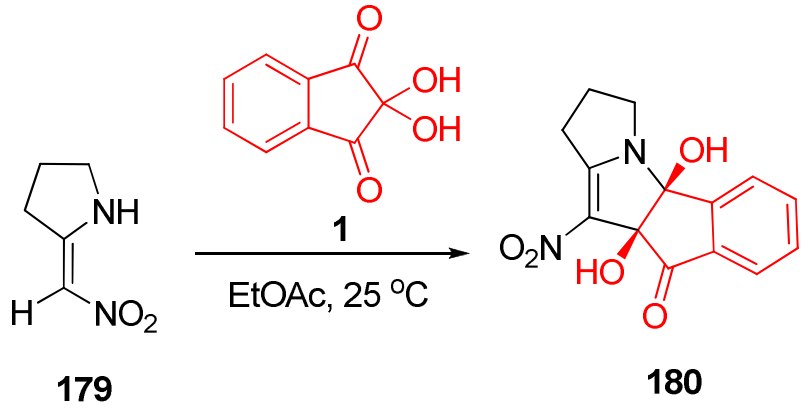

Scheme 49. Reaction of ninhydrin with 2-nitromethylenepyrrolidine.

Highly substituted vic-dihydroxyindenoindole 182 was prepared from a solution of equimolar amounts of corresponding enaminone $\mathbf{1 8 1}$ and ninhydrin $\mathbf{1}$ in chloroform, stirred at room temperature for $24 \mathrm{~h}$ (Scheme 50). ${ }^{247}$ Compound 182 was investigated for its in vitro cytotoxic activity against six human tumour cell lines and two nontumourogenic cell lines. Its in vitro activity against Mycobacterium tuberculosis was also reported and in general, it was found to possess a marginal activity. 


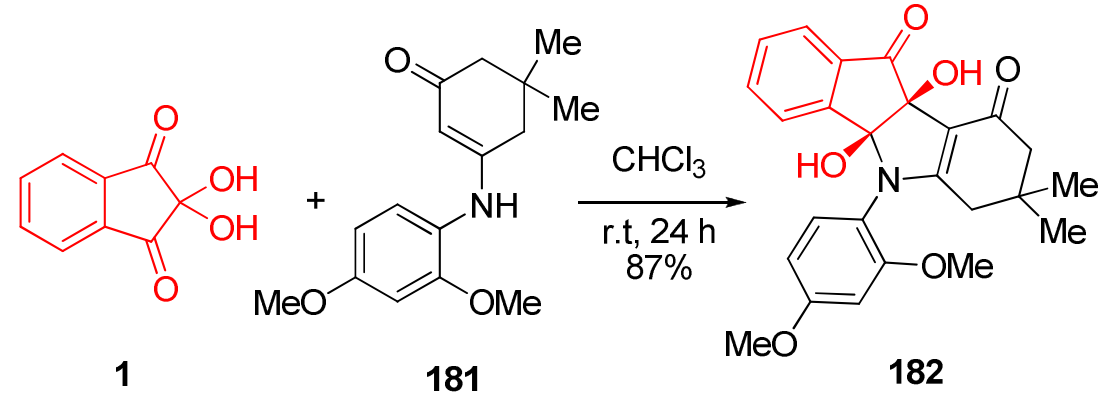

Scheme 50. Regiospecific synthesis of vic-dihydroxyindenoindole.

The application of the 1,3-dipolar cycloaddition reaction of an azomethine ylide, generated in situ from ninhydrin 1 and 1,2,3,4-tetrahydroisoquinoline 183, with chalcone derivatives 147 was reported by Sarrafi and co-workers. In this study, a new class of spiroindane-1,3-diones $\mathbf{1 8 6}$ were obtained in a regio- and diastereo-controlled manner (Scheme 51). ${ }^{248}$
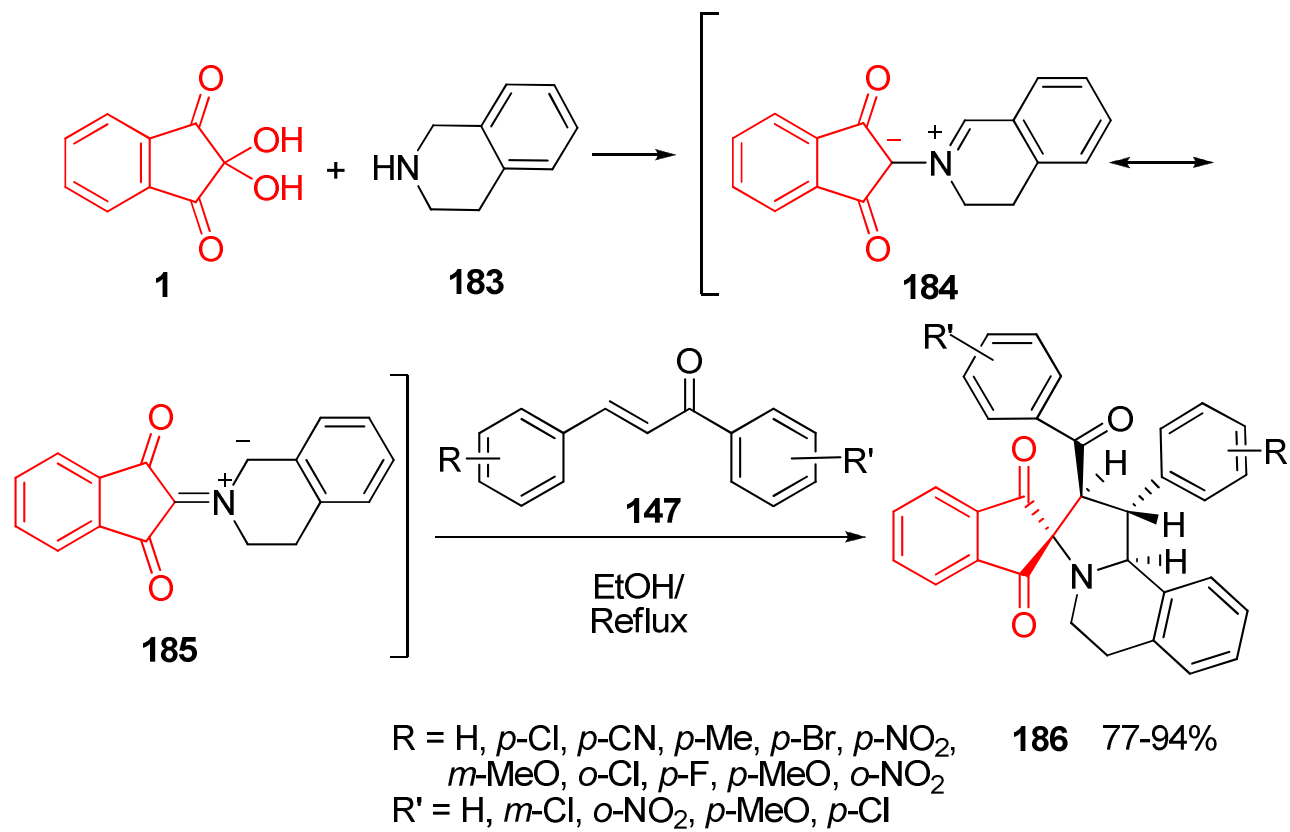

Scheme 51. Reaction of ninhydrin, 1,2,3,4-tetrahydroisoquinoline, and chalcone derivatives reported by Sarrafi.

3.1.3. Pyrazolines. Pyrazolines are biologically active and therapeutically useful compounds. ${ }^{249-251}$ A convenient method for the synthesis of racemic phenylindeno[1,2-c]pyrazol-4(1H)-ones 188 via the sequential reaction between benzaldehydes, phenylhydrazine 187, and ninhydrin in $\mathrm{MeCN}$ was described by Yavari and co-workers (Scheme 52). ${ }^{252}$ 


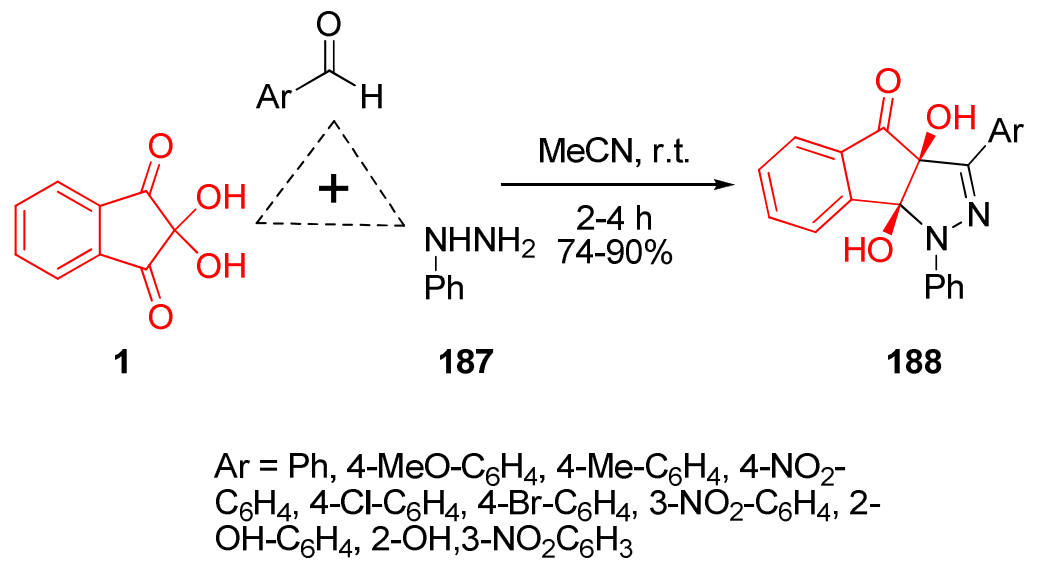

Scheme 52. Three-component synthesis of phenylindeno[1,2-c]pyrazol-4(1H)-ones.

In a study by Alizadeh and co-workers, a synthetic route to highly functionalized $1 \mathrm{H}$-pyrazole3-carboxylates 189 was developed via a one-pot three-component domino reaction of phenylhydrazines 187, dialkyl acetylenedicarboxylates 41, and ninhydrin 1 under mild conditions (Scheme 53). ${ }^{253}$

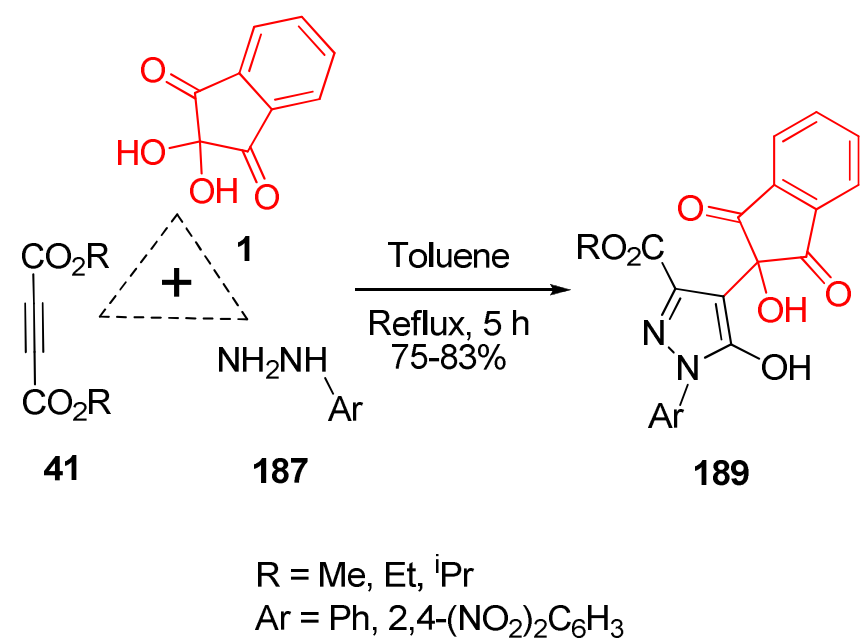

Scheme 53. Three-component synthetic route to highly functionalized $1 H$-pyrazole-3-carboxylates reported by Alizadeh.

3.1.4. Imidazoles and imidazolidines. Imidazole nucleus is a constituent of many bioactive heterocyclic compounds that are of wide interest because of their diverse biological and clinical applications. ${ }^{254-257}$ Additionally, imidazolidines have attracted considerable attention from synthetic organic chemists since these scaffolds exhibit significant pharmacological properties. ${ }^{258-260}$ The reaction of ninhydrin with urea was first reported by Van Slyke and Hamilton in 1941, ${ }^{261}$ and two years later, they reported the formation of a stable ninhydrin-urea compound. ${ }^{262}$ Recently, nineteen new spirohydantoins were synthesized in three steps, outlined in Scheme 54: the ureas not 
commercially available were prepared by the addition of a primary amine to the appropriately substituted isocyanate 190. The disubstituted ureas 191 were then reacted with ninhydrin $\mathbf{1}$ to give indeno[1,2- $d$ ] imidazolidine-2,8-diones 192. Subsequent oxidation of the latter with $\mathrm{NaIO}_{4}$ exclusively yielded one regioisomer of the $N, N^{\prime}$-disubstituted phthalidyl spirohydantoins $\mathbf{1 9 3}{ }^{263-264}$ The anticonvulsant activities of these compounds were also evaluated, with most showing the ability to inhibit pentylenetetrazol-induced convulsions.
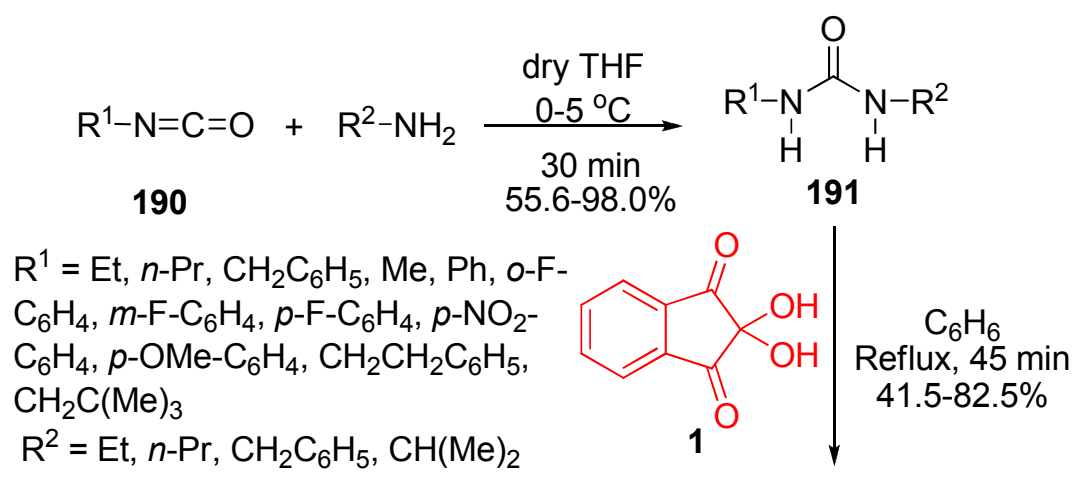<smiles>[R]N1C(=O)N([R])[C@]2(OC(=O)c3ccccc32)C1=O</smiles>

193

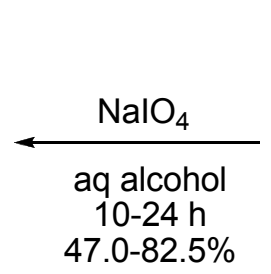

$47.0-82.5 \%$

192

Scheme 54. Synthesis of regioisomer of the $N, N^{\prime}$-disubstituted phthalidyl spirohydantoins.

Ninhydrin reacts with compounds 194 according to Scheme 55 to give meso 1,4-diazaspiro[4,4]nonanes 195. ${ }^{266}$

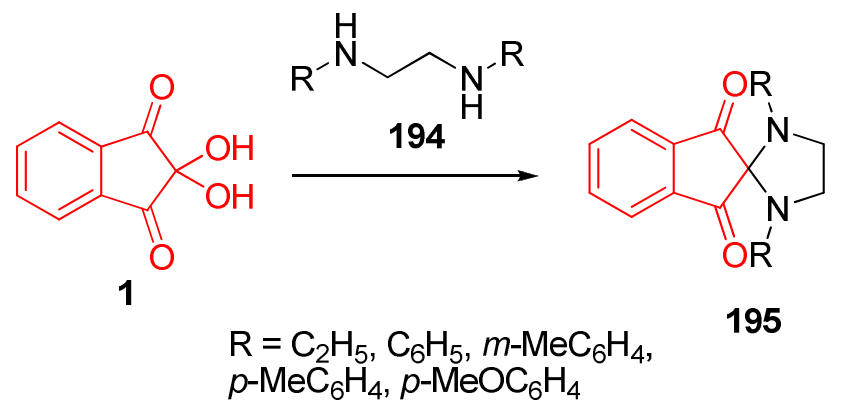

Scheme 55. Synthesis of meso 1,4-diazaspiro-[4,4]nonanes. 
Highly substituted indeno[1,2-d]imidazoles 197 were synthesized via a tandem additioncyclization reaction of primary amines, aryl isothiocyanates 196, and ninhydrin 1 under solvent free conditions (Scheme 56). ${ }^{267}$

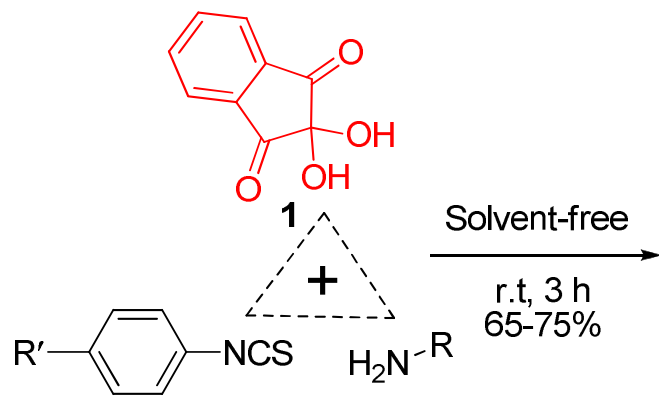

196<smiles>[R]N1C(=S)N([Al])[C@]2(O)c3ccccc3C(=O)[C@@]12O</smiles>

197

$\mathrm{R}=\mathrm{Pr}, \mathrm{Bn},{ }^{i} \mathrm{Bu}, 4-\mathrm{MeC}_{6} \mathrm{H}_{4} \mathrm{CH}_{2}$
$\mathrm{R}^{\prime}=\mathrm{H}, \mathrm{Me}, \mathrm{Cl}$

Scheme 56. Three-component synthesis of substituted indeno[1,2- $d]$ imidazoles.

Synthesis of indeno[1,2- $d$ ] imidazolidin-2-iminium chloride 199 as a new ninhydrin derivative was achieved from an aqueous solution of guanidinium chloride 198 and ninhydrin in equimolar amounts (Scheme 57). ${ }^{268}$ The molecular structure of 199 was experimentally determined using single crystal X-ray technique.<smiles>O=C1c2ccccc2C(=O)C1(O)O</smiles>

1<smiles>NC(=[NH2+])[NH3+]</smiles>

198

199

Scheme 57. Synthesis of indeno[1,2- $d]$ imidazolidin-2-iminium chloride from guanidinium chloride and ninhydrin.

An efficient synthesis of functionalized tetrahydroimidazoles 200 via a one-pot tandem reaction between ninhydrin 1, primary alkylamines, aryl isocyanates or aryl isothiocyanates 196, acetylenic esters 41 and triphenylphosphine was described by Hossaini and co-workers (Scheme 58). ${ }^{269}$

Azizian's group introduced a procedure for the diastereoselective synthesis of highly functionalized dihydrofuran derivatives $\mathbf{2 0 3}$ via the intramolecular Wittig reaction on dihydroxyindeno[1,2- $d$ ] imidazole 201, which was easily synthesized from the addition reaction of ninhydrin 1 and urea (Scheme 59). ${ }^{270}$ Two diastereomers $\mathbf{2 0 3}$ and 203' are possible for compounds 203, with NOE experiments confirming the formation of the $\mathbf{2 0 3}$ isomers. This interesting stereochemical outcome was rationalized by considering a steric repulsion between ester group and 
imidazole-dione ring at the phosphorane isomers 202' and 202, and thus the 203 isomers were assigned to the crystalline products.

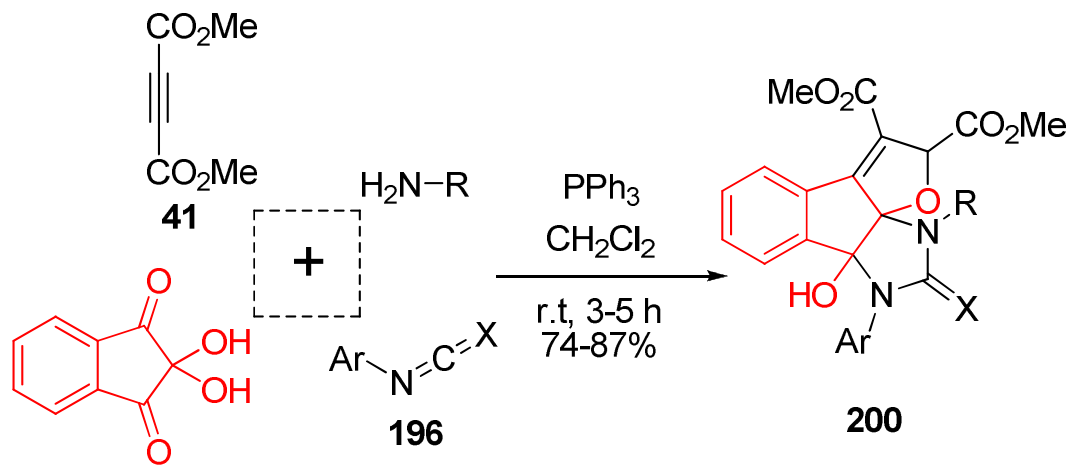

1

$\mathrm{Ar}=\mathrm{Ph}, 4-\mathrm{FC}_{6} \mathrm{H}_{4}, 2,4-\mathrm{Cl}_{2} \mathrm{C}_{6} \mathrm{H}_{3}, 4-\mathrm{NO}_{2} \mathrm{C}_{6} \mathrm{H}_{4}$

$\mathrm{R}=4-\mathrm{MeO}-\mathrm{Bn}, 4-\mathrm{Me}-\mathrm{Bn}$, Allyl, $\mathrm{Me}, \mathrm{Et}$

$\mathrm{X}=\mathrm{O}, \mathrm{S}$

Scheme 58. Four-component synthesis of functionalized tetrahydroimidazoles.

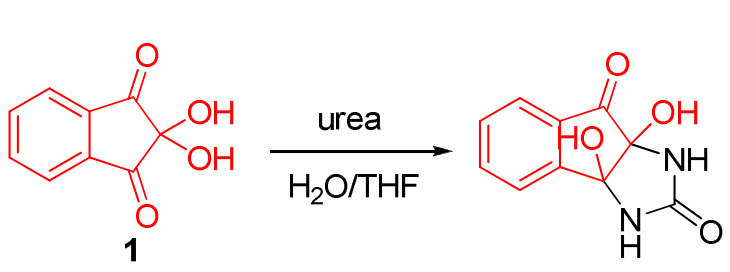

$\mathrm{R}=\mathrm{Me}, \mathrm{Et}, t-\mathrm{Bu}$

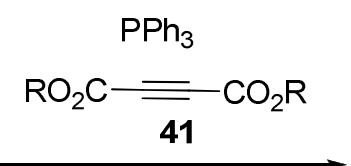

r.t, 2 h, $84-94 \%$

201

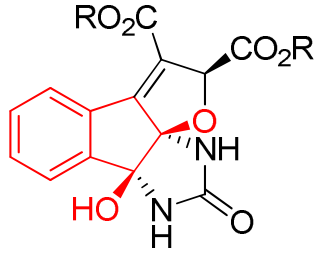

203

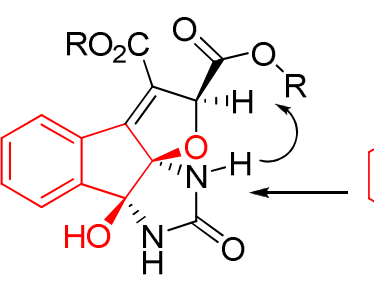

203

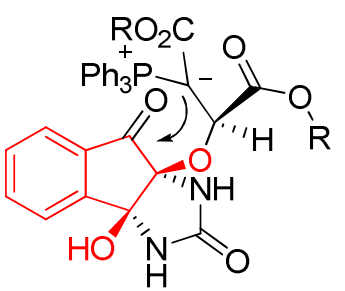

202

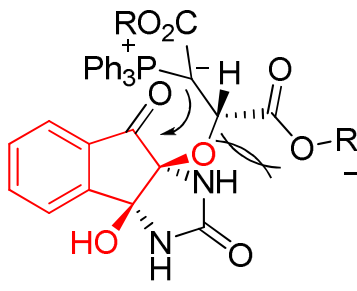

202'

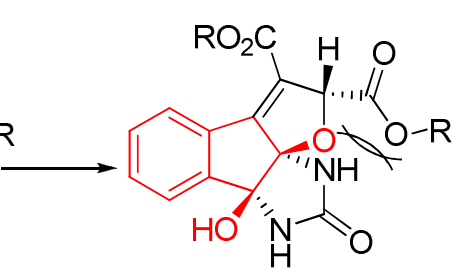

203'

Scheme 59. Mechanism of diastereoselective synthesis of highly functionalized dihydrofuran derivatives.

When phenols 204 are refluxed in a mixture of ninhydrin and acetic acid, 2-hydroxy-2-(2'hydroxy-aryl)-1,3-indanediones $\mathbf{2 0 5}$ are formed, and preferentially remain in the cyclic hemiketal form 206. ${ }^{74,160}$ With this in mind, Pramanik and co-workers reported refluxing 206 with urea in acetic acid (one pot reaction) to produce isoindole fused imidazoles with phenolic subunits $\mathbf{2 0 7}$ (Scheme 60). ${ }^{271}$ It was observed that in aprotic solvent, they show high fluorescent properties, but in protic polar solvent, fluorescent intensity decreases. 


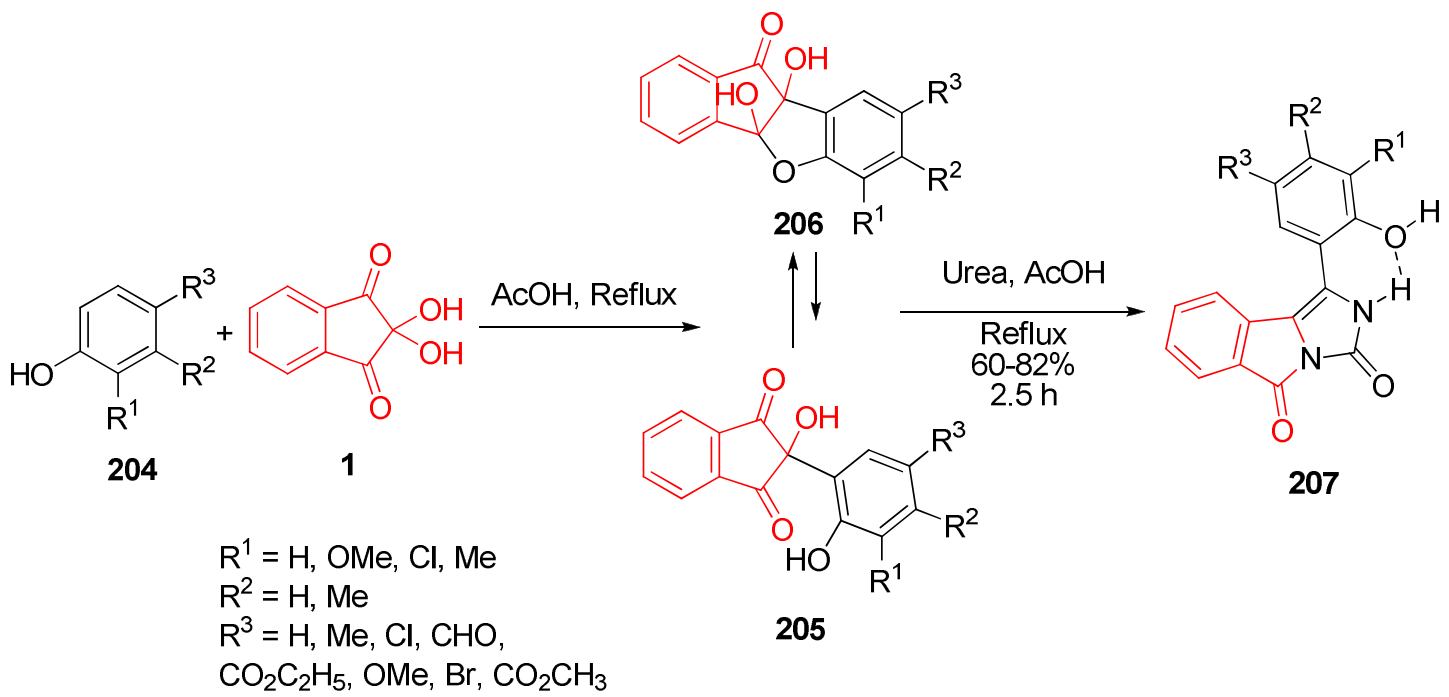

Scheme 60. Synthesis of isoindole fused imidazoles with phenolic subunits from ninhydrin, phenols, and urea.

The reaction of ninhydrin with thiourea in water $(1 \mathrm{~h})^{272}$ or $\mathrm{AcOH}$ in a relative short time (15 min) gives maximum yield $(100 \%)$, and the products exhibit promising antimicrobial activity against gram positive bacteria, gram negative bacteria and a fungus strain C. albicans. ${ }^{273}$ Its noncovalent interactions were also carefully analyzed in terms of crystal engineering and supramolecular chemistry. Subsequently, the same group synthesized two indeno imidazoles 209 from the reaction of ninhydrin with diphenylurea or diphenylthiourea 208 and examined their antimicrobial activities, which showed good antibacterial activity against $B$. subtilis and $P$. aeruginosa (Scheme 61). ${ }^{274}$ However, the authors did not determine or comment on the stereochemistry of the compounds.

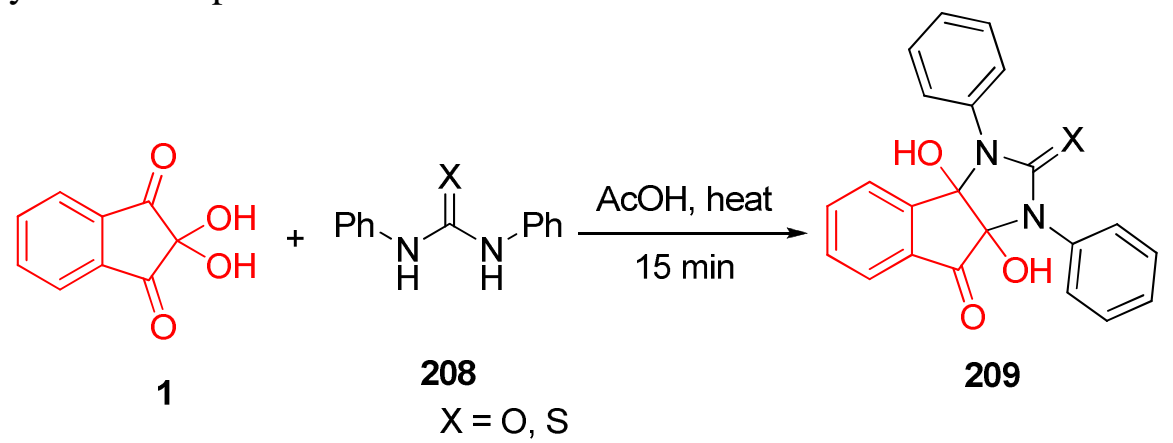

Scheme 61. Synthesis of indeno imidazoles from the reaction of ninhydrin with diphenylurea or diphenylthiourea.

\subsection{O-Heterocyclic compounds}

3.2.1. $\gamma$-Lactones. Lactones are useful starting materials in the synthesis of various types of heterocyclic organic compounds. The use of suitably substituted lactones is particularly favorable in 
the synthesis of polycyclic heterocyclic systems. ${ }^{275-276}$ In 1910, Ruhemann observed that ninhydrin rearranges in base to give $o$-carboxymandelic acid $\mathbf{2 1 0}$ (isolated as its lactone 211). ${ }^{1}$ Later, Bowden and Rumpal described a detailed investigation of base-catalysed ring fission of a series of substituted ninhydrins (Scheme 62). ${ }^{277}$

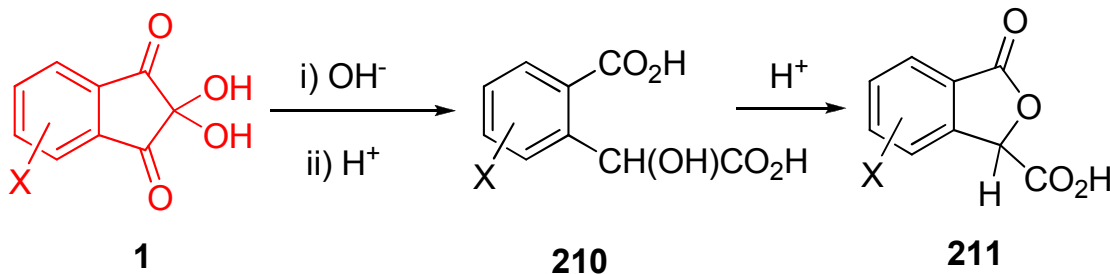

Scheme 62. Rearrangement of ninhydrin to give $o$-carboxymandelic acid.

The results of studies on the synthesis and the photochemistry of some racemic $N$-(2-hydroxy1,3-dioxo-1,3-dihydro-2H-inden-2-yl)aryl/heteroarylamides 212 were reported by Kapoor et al. It was concluded that the inclusion of hydroxyl and aryl/heteroarylamidogroup at C-2 did not alter the course of the phototransformation, which still involved $\alpha$-cleavage of the $2 H$-indene-1,3-dione moiety (Scheme 63). ${ }^{278}$
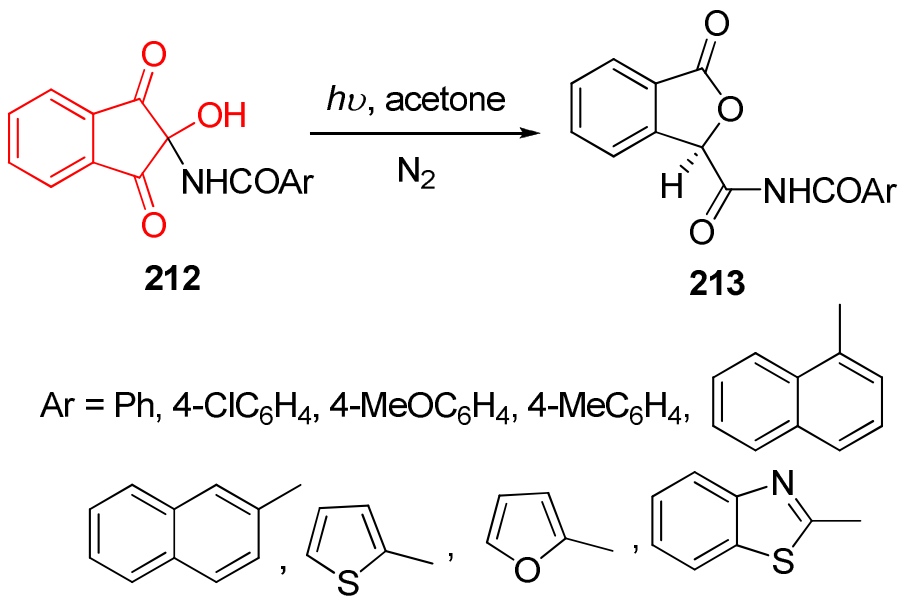

Scheme 63. Photochemistry of $N$-(2-hydroxy-1,3-dioxo-1,3-dihydro- $2 H$-inden-2-yl) aryl/heterylamides.

While indane-1,2,3-trione 2 is conveniently prepared in quantitative yield by the azeotropic drying of ninhydrin using chlorobenzene as solvent, ${ }^{279}$ the photochemical reaction of ninhydrin in degassed alcoholic solutions also takes place via formation of $\mathbf{2}$ and affords 3alkoxycarbonylphthalides $\mathbf{2 1 4}$ as the major product together with 3-alkoxyphthalides $\mathbf{2 1 5}$ (Scheme 64) ${ }^{280}$ The photochemistry of ninhydrin was shown to be dependent on the solvent ${ }^{281}$ and the photochemical reaction of ninhydrin derivatives in various solvents was investigated. ${ }^{282-283}$ In another study, it was found that indan-1,2,3-trione $\mathbf{2}$ undergoes photodecarbonylation rather efficiently to produce $\mathbf{2 1 6}$ and $\mathbf{2 1 7}$, which are in a photoequilibrium (Scheme 65). ${ }^{284}$ 
<smiles>O=c1c(=O)c(=O)c2ccccc2c1=O</smiles>

1

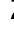

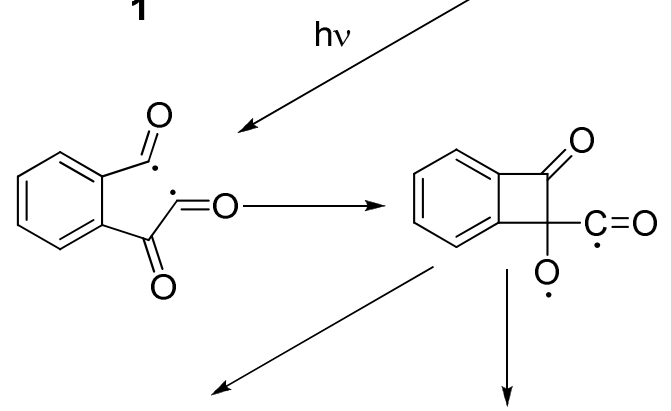<smiles>O=C1OC12OC2=O</smiles><smiles>O=CC12OC1(O)c1ccccc12</smiles><smiles>[R]OC(=O)C1OC(=O)c2ccccc21</smiles><smiles>CC(=O)C(O)I</smiles>

214<smiles>[R]C1OC(=O)c2ccccc21</smiles>

$\mathrm{R}=\mathrm{Me}, \mathrm{Et}, i-\mathrm{Pr}$

Scheme 64. Photochemical reaction of ninhydrin reported by Tatsugi.<smiles>O=c1c(=O)c2ccccc2c1=O</smiles>

2<smiles>O=C[Co]</smiles>

216

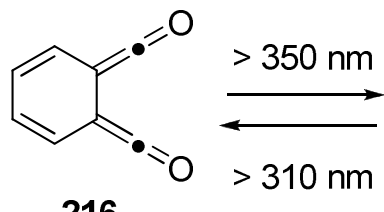

16<smiles>O=c1c(=O)c2ccccc12</smiles>

217

Scheme 65. Photodecarbonylation of indan-1,2,3-trione.

Ninhydrin is a suitable substrate in the ruthenium-catalyzed intermolecular carbonylative $[2+2+1]$ cycloaddition reaction with ethylene and $\mathrm{CO}$ to give the meso spirolactone 218 (Scheme 66). ${ }^{285}$ The reaction takes place specifically at the central carbonyl group, which is expected to be more reactive than the terminal carbonyl groups. 
<smiles>O=C1c2ccccc2C(=O)C1(O)O</smiles>

1

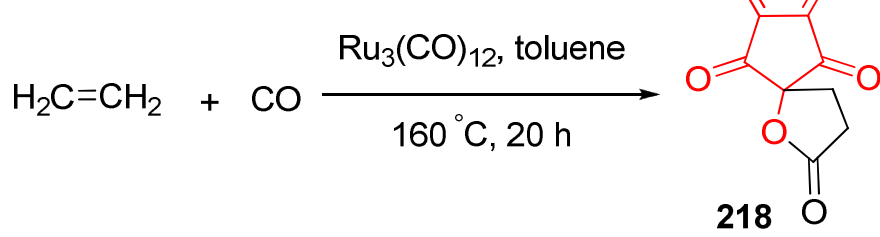

Scheme 66. Ruthenium-catalyzed reaction of ninhydrin with ethylene and CO.

Kim and co-workers successfully prepared indenoindene-fused $\alpha$-methylene- $\gamma$-butyrolactones 224 via a tandem intra- and inter-molecular Friedel-Crafts reaction from a spiro-lactone 221, which is easily prepared from ninhydrin 1 by means of an indium-mediated Barbier reaction with cinnamyl bromide 219 (Scheme 67). ${ }^{286}$ Some products were obtained as single isomers.<smiles>O=C1c2ccccc2C(=O)C1(O)O</smiles>

1

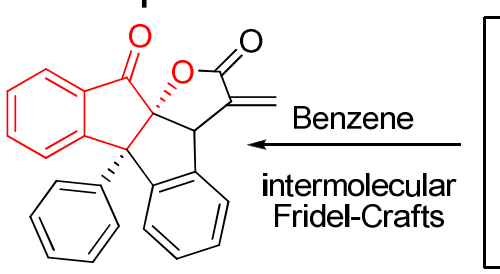

224<smiles>COC(=O)C(=Cc1ccccc1)CBr</smiles>
219<smiles>C=C(C(=O)OC)C(c1ccccc1)C1(O)C(=O)c2ccccc2C1=O</smiles>

220<smiles>C=C1C(=O)OC2(C(=O)c3ccccc3C2=O)C1c1ccccc1</smiles>

221<smiles>C=C(C)C1C(=O)OC2(C(=O)c3ccccc32)c2ccccc21</smiles>

223<smiles>C=C1C(=O)OC2(C(=O)c3ccccc31)c1ccccc12</smiles>

222

Scheme 67. Synthesis of indenoindene-fused $\alpha$-methylene- $\gamma$-butyrolactones via a tandem FriedelCrafts reaction.

Maghsoodlou's group used aromatic ketones (11H-indeno[1,2-b]quinoxalin-11-one) $\mathbf{1 2 6}$ and dimethyl acetylenedicarboxylate (DMAD) 41 in the presence of N-heterocycles 225 such as pyridine, quinoline, and isoquinoline for the synthesis of a racemic mixture of spirolactone derivatives 226 (Scheme 68). ${ }^{287}$ 
<smiles>O=C1c2ccccc2C(=O)C1(O)O</smiles><smiles>[R]c1cc2nc3c(nc2cc1[R])-c1ccccc1C3=O</smiles>

126<smiles>[R]c1cc(N)c(N)cc1[R]</smiles>

117

$\begin{array}{ccc}\mathrm{R}^{1} & \mathrm{R}^{2} & \mathrm{~N} \text {-heter } \\ \mathrm{H} & \mathrm{H}\end{array}$

Me Me<smiles>c1ccncc1</smiles>

$\mathrm{H}$<smiles>CC</smiles><smiles>c1ccc2cnccc2c1</smiles>

90

Me<smiles>Cc1ccc2ccncc2c1</smiles>

$\mathrm{H} \quad \mathrm{H}$<smiles>c1ccc2ncccc2c1</smiles>

$\mathrm{Me}$

89

87

84

81
Me<smiles>c1ccc2ncccc2c1</smiles>

226<smiles>[R]C1=C([R])C(OC)N(C2=C(C(=O)OC)C3(OC2=O)c2ccccc2-c2nc4cc([R])c([R])cc4nc23)C([R])=C1[R]</smiles>

225

yield (\%)

91

Scheme 68. Synthesis of spirolactone derivatives from ketones (11H-indeno[1,2- $b$ ]quinoxalin-11one), DMAD, and N-heterocycles.

On stirring an equimolar mixture of 4-oxo-4H-chromene-3-carbaldehyde 94, ninhydrin 1 and cyclohexyl isocyanide 227 in $\mathrm{CH}_{2} \mathrm{Cl}_{2}-\mathrm{MeOH}$ (7:1) at room temperature, the synthesis of iminolactone $\mathbf{2 3 0}$ was investigated. Hydrolysis of the latter leads to the formation of racemic lactone 231 (Scheme 69). ${ }^{288}$ 
<smiles>[R]c1ccc2c(c1)C(=O)C(=CO)C(CC(C)C)OC2C(C)C</smiles>
$\mathrm{R}=\mathrm{H}, \mathrm{Me}, \mathrm{Cl}$ 228

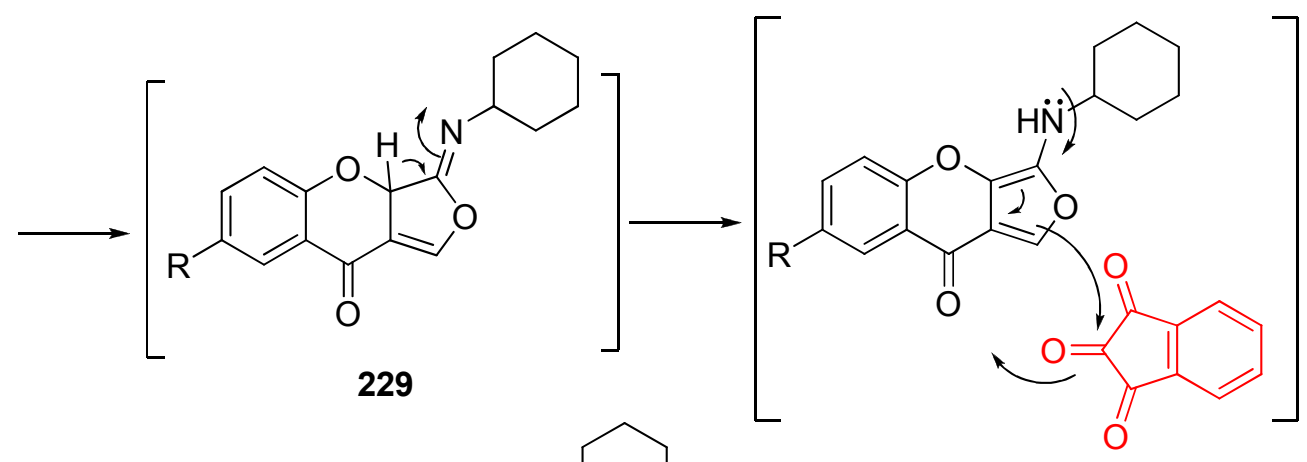

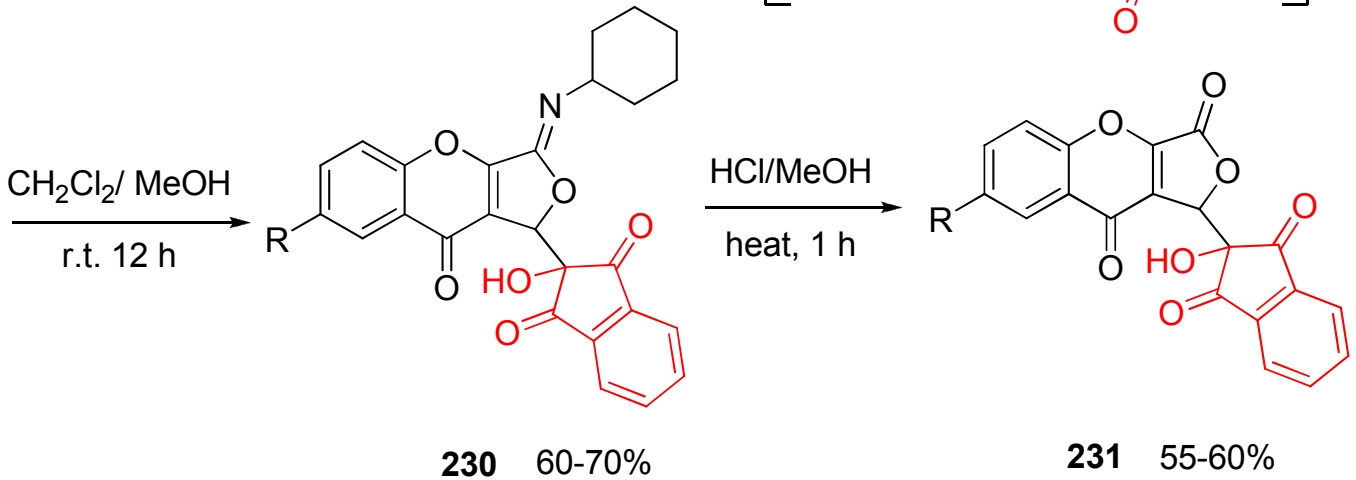

Scheme 69. Mechanism proposed to explain the synthesis of lactones from 4-oxo-4H-chromene-3carbaldehyde, ninhydrin, and cyclohexyl isocyanide.

In an attempt to study the photorearrangements of spiro-conjoined cyclohexa-2,5-dien-1-one 236, compound 232 was chosen as a possible precursor, which is expected to afford cyclopropane compound 233 upon oxidation. The product has an intramolecular hemiacetal structure, 234, rather than the expected dihydroxyphenyl structure 233. Compound 234 was oxidized by potassium hexacyanoferrate (III), the product, however, was the ring-expanded lactone 235 (52\%) and the spiro-conjoined cyclohexa-2,5-dien-1-one 236 (24\%) (Scheme 70). When 237 was utilized as a precursor, the product was the benzofuran-condensed eight-membered lactone ring 239 (20\%) (Scheme 71). ${ }^{289}$ 


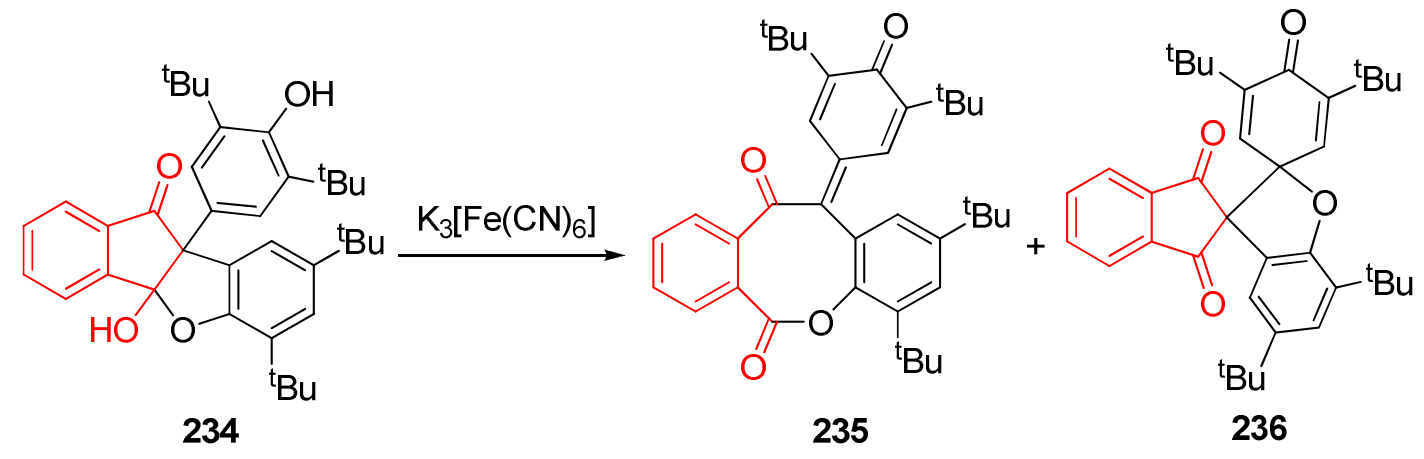<smiles>CC(C)(C)c1cc(Br)c(O)c(C2(c3cc(C(C)(C)C)cc(C(C)(C)C)c3O)C(=O)c3ccccc3C2=O)c1</smiles>

232

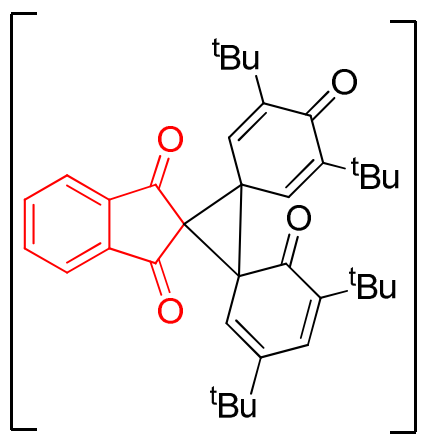

233

Scheme 70. Synthesis of ring-expanded lactone from potassium hexacyanoferrate (III) oxidation reaction.<smiles>CC(C)(C)c1cc(C(C)(C)C)c(O)c(C2(c3cc(C(C)(C)C)cc(C(C)(C)C)c3O)C(=O)c3ccccc3C2=O)c1</smiles><smiles>CC(C)(C)c1cc2c(c(C(C)(C)C)c1)OC(O)(c1cc(C(C)(C)C)cc(C(C)(C)C)c1O)c1c(cc(C(C)(C)C)cc1C(C)(C)C)C2=O</smiles>

Scheme 71. Synthesis of benzofuran-condensed eight-membered lactone ring. 
3.2.2. Tetrahydro- and dihydrofurans. Tetrahydrofuran and dihydrofuran skeletons are important structural cores of many biologically relevant molecules. ${ }^{290-294}$ Naturally occurring furan-fused polycyclic compounds have been known to possess unique biological activities and interesting structural frameworks. Yavari and co-workers studied the reactions of ninhydrin $\mathbf{1}$ with 2 equivalents of dialkyl acetylenedicarboxylates $\mathbf{4 1}$ in the presence of two equivalents of triphenylphosphine in dry acetone to afford $C_{2}$-symmetric tetra- alkyl 2,5-dihydrofuro[2',3':2,3]indeno[2,1-b]furan-1,2,5,6- tetracarboxylates $\mathbf{2 4 0}$ as a racemate in excellent yields (Scheme 72). ${ }^{295}$ This procedure provides an acceptable one-pot method to prepare axial symmetrical derivatives of ninhydrin.

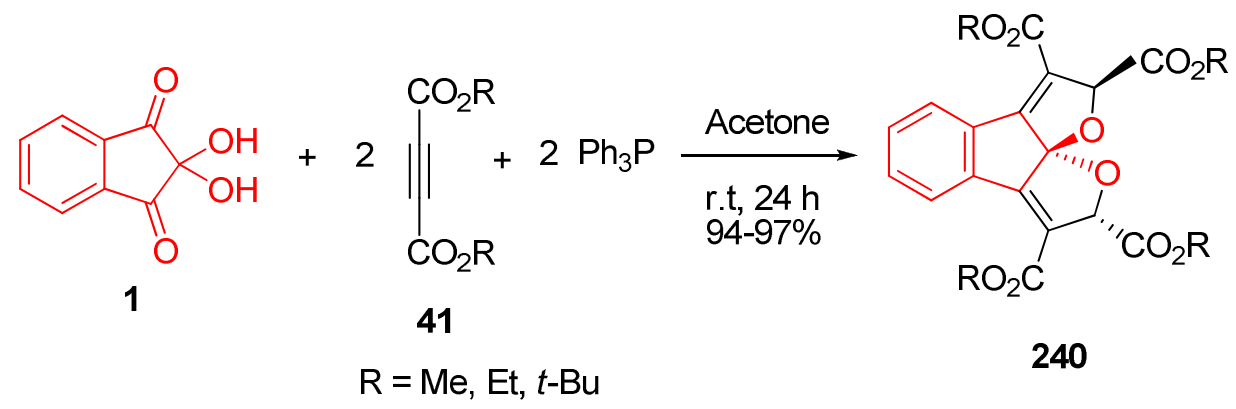

Scheme 72. Reaction of ninhydrin with DMAD in the presence of triphenylphosphine reported by Yavari.

Recently, an effective route to functionalized $5 H$-spiro[furan-2,2'-indene]-1',3',5-triones 241 was also described by this group via the tandem reaction of primary amines, dialkyl acetylenedicarboxylates $\mathbf{4 1}$ and ninhydrin (Scheme 73). ${ }^{296}$ Presumably, the enamino-ester intermediate $\mathbf{5 0}$ is attacked by $\mathbf{1}$ to furnish the intermediate 242, which undergoes proton-transfer reaction to produce the imine derivative 243. This intermediate undergoes imine-enamine tautomerization to generate $\mathbf{5 1}$, which is converted to $\mathbf{2 4 1}$ by elimination of $\mathrm{R}^{2} \mathrm{OH}$. This method also works well with secondary amines. ${ }^{297}$ Compound $\mathbf{2 4 1}$ is of meso form while $\mathbf{2 4 2}$ and $\mathbf{2 4 3}$ are racemates.

Aliev and co-workers showed that when equivalent amounts of acetylpyruvic acid methyl ester 63, ninhydrin 1, and methylamine are mixed in dioxane with brief heating, methylammonium 4acetyl-2,1',3'-trioxospiro[2,5-dihydrofuran-5,2'-indan]-3-olate $\mathbf{2 4 4}$ is formed (Scheme 74). ${ }^{298}$ 


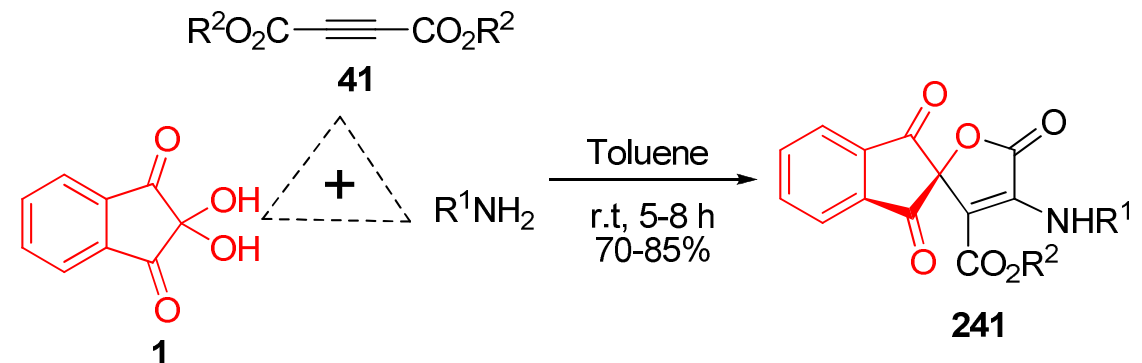

$\mathrm{R}^{1}=\mathrm{Et}, n-\mathrm{Bu}, \mathrm{c}-\mathrm{Hexyl} \mathrm{Bn}, \mathrm{Ph}$, Benzothiazol-2-yl

$\mathrm{R}^{2}=\mathrm{Me}, \mathrm{Et}$

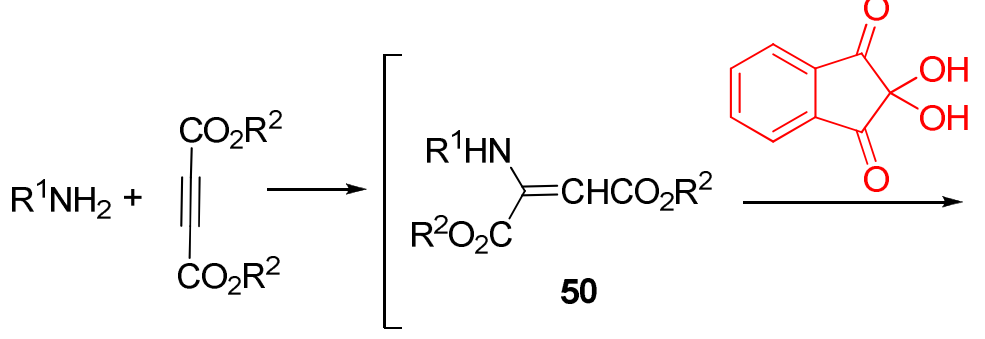

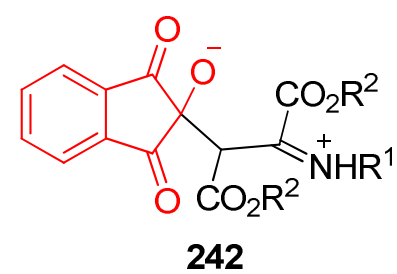<smiles>[R2]N/C(C(=O)O[R2])=C(\[R])C1(O)C(=O)c2ccccc2C1=O</smiles><smiles>[R2]OC(=O)C(C(=[R2])C([R2])=O)C1(O)C(=O)c2ccccc2C1=O</smiles>

243

Scheme 73. Mechanism that explains the tandem reaction of primary amines, DMAD, and ninhydrin.<smiles>O=C1c2ccccc2C(=O)C1(O)O</smiles>

1<smiles>CC(=O)C=C(O)C(=O)O[C+]N</smiles>

63<smiles>CC(=O)C1=C(O)C(=O)OC12C(=O)c1ccccc1C2=O</smiles>

$24456 \%$

Scheme 74. Reaction of acetylpyruvic acid methyl ester, ninhydrin, and methylamine.

The same group reported the interaction of methyl esters of acylpyruvic acids $\mathbf{2 4 5}$ with ninhydrin whilst stirring in a water-dioxane (9:1) mixture leading to meso 4-acyl-3-hydroxyspiro[2,5-dihydrofuran-5,2'-indan]-2,1',3'-triones 246 (Scheme 75). ${ }^{299}$ It was established that all the synthesized compounds exhibited weak antimicrobial activity with respect to standard strains of Staphylococcus aureus and Escherichia coli with MIC ranging from 500 to $1000 \mu \mathrm{g} / \mathrm{ml}$. 


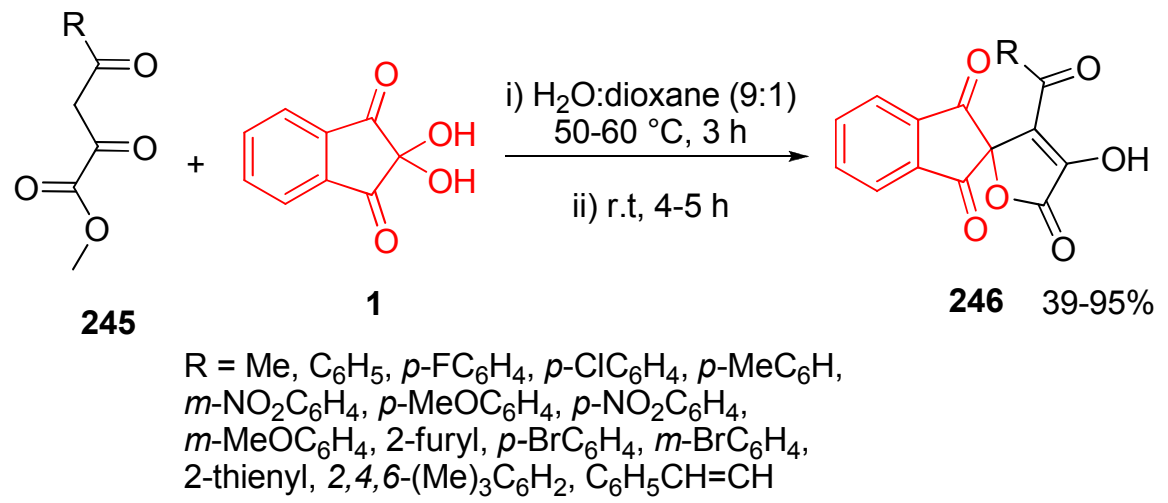

Scheme 75. Water-dioxane mediated reaction of acylpyruvic acids with ninhydrin.

Highly reactive 1:1 intermediates are produced in the reaction of $\mathrm{Ph}_{3} \mathrm{P}$ and dialkyl acetylenedicarboxylates 41. Protonation of these intermediates by alcohols leads to vinyltriphenyl phosphonium salts $\mathbf{2 4 7}$, followed by a Michael addition reaction with the conjugate base to produce the corresponding stabilized phosphonium ylides 248. Wittig reaction of the stabilized phosphonium ylides $\mathbf{2 4 8}$ with ninhydrin 1 produces densely functionalized $2 H$-indeno[2,1- $b$ ]furans 250 as racemic mixtures (Scheme 76). ${ }^{300-302}$

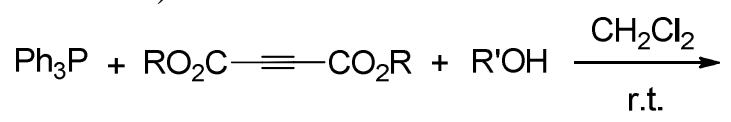

41
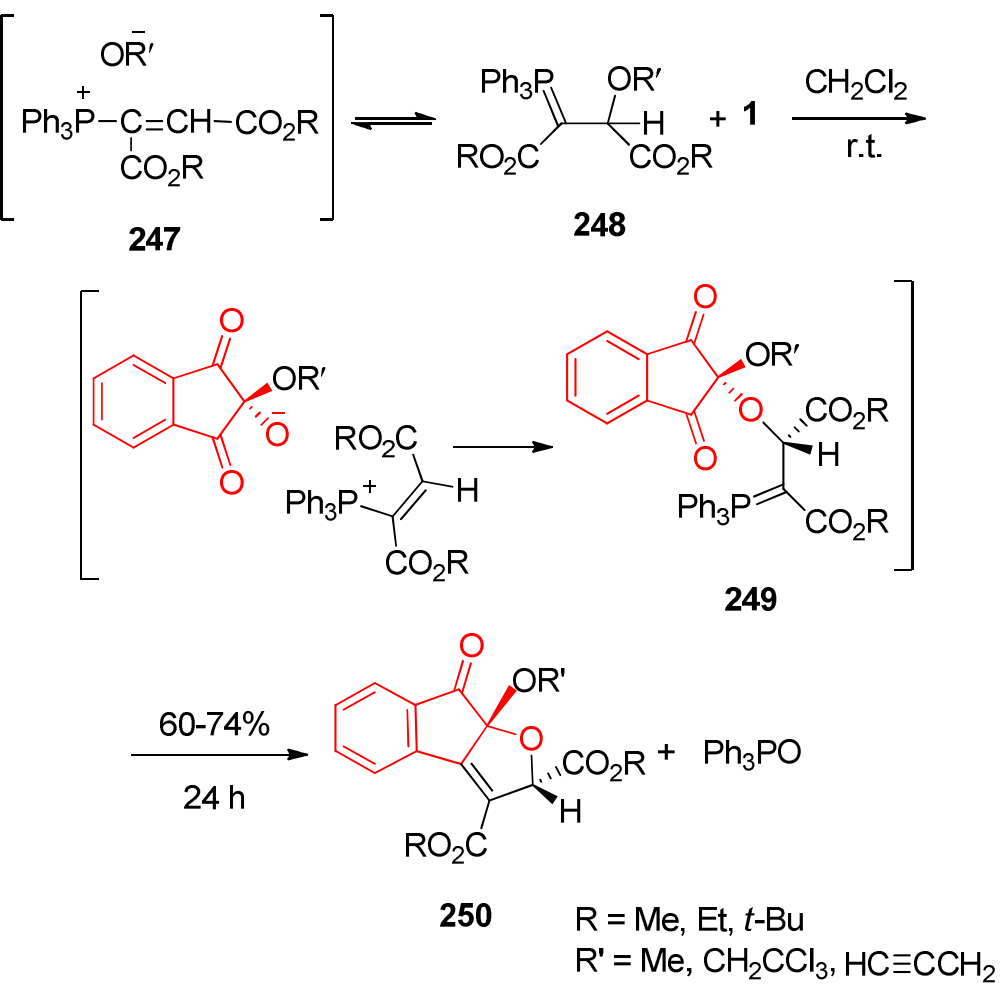

Scheme 76. Mechanistic explanation of the synthesis of densely functionalized $2 H$-indeno[2,1- $b]$ furans. 
Reaction of ninhydrin with 4-methylpyridazine or 4-methylquinoline gives access to 2-hydroxy2-heteroaryhethyl-13-indanediones 251, which on subsequent reaction with methyl(di)azines (with the methyl group in $\alpha$-position to a ring nitrogen atom), results in the exclusive formation of novel compound 253. The latter appears to result from cyclisation of the intermediate 2,2'-dihydroxy-2,2'(heteroaryl)bis-1,3-indanediones 252 (Scheme 77). ${ }^{303}$

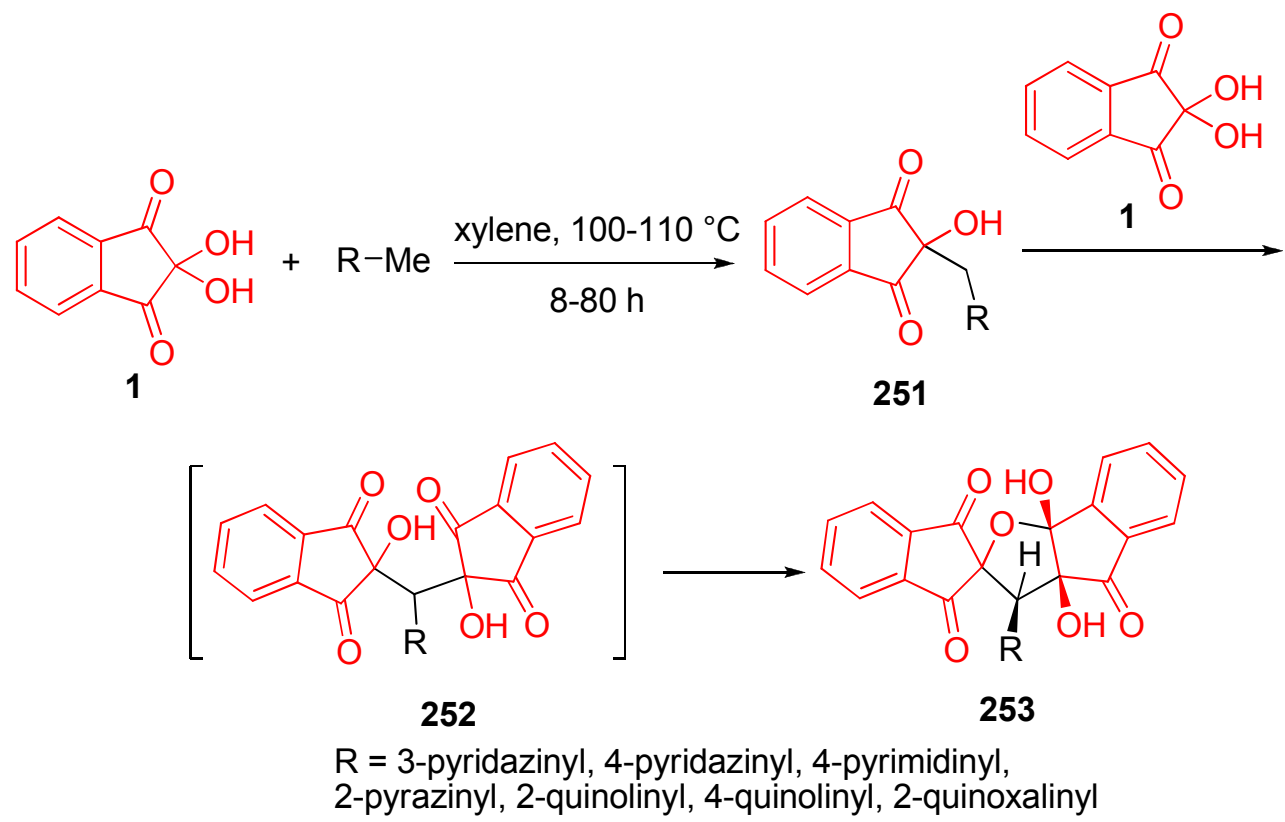

Scheme 77. Mechanism that accounts for the formation of novel compound 253.

3.2.3. Benzofurans and isobenzofurans. Benzofuran derivatives represent an important source of biologically active compounds which can be used to design and develop new potentially useful therapeutic agents. ${ }^{304-306}$ In addition, isobenzofurans are an important class of natural products possessing significant biological properties. ${ }^{307-309}$ Pramanik's group used 2-hydroxy-2,2'-biindan$1,1^{\prime}, 3,3^{\prime}$-tetrone 254 in a condensation reaction with various phenols, polyhydroxy benzenes, and $\alpha$ and $\beta$-naphthols 255 in an acid medium to produce 2-aryl/alkyl-2,2'-biindan-1,1',3,3'-tetrones 256. ${ }^{1} \mathrm{H}$ and ${ }^{13} \mathrm{C}$ NMR spectra from adducts of $\mathbf{2 5 6}$, in the case of substrates such as resorcinol, orcinol, 1,3,5-trihydroxybenzene and $\alpha$ - and $\beta$-naphthols, indicate that such derivatives prefer the intramolecular hemi-ketal form 257 (Scheme 78). ${ }^{310}$ It was observed that para- or meta-substituted phenols 204 condense with 254 in acid medium to furnish meso 2',4-spiro(1',3'-indanedione)indeno[3,2-b]chromenes 260 in fairly good yields (Scheme 79). ${ }^{310}$ Application of various enolic compounds such as acetylacetone, ethyl and methyl acetoacetate in condensation with 254 in acetic acid medium was also investigated. ${ }^{311}$ 
<smiles>O=C1c2ccccc2C(=O)C1C1C(=O)c2ccccc2C1=O</smiles><smiles>[R]c1c([R])c([R])c(C2(C3C(=O)c4ccccc4C3=O)C(=O)c3ccccc3C2=O)c([R4])c1[R]</smiles><smiles>[R]c1cc([R])c([R])c([R])c1[R1]</smiles>

$256 \quad 55-73 \%$

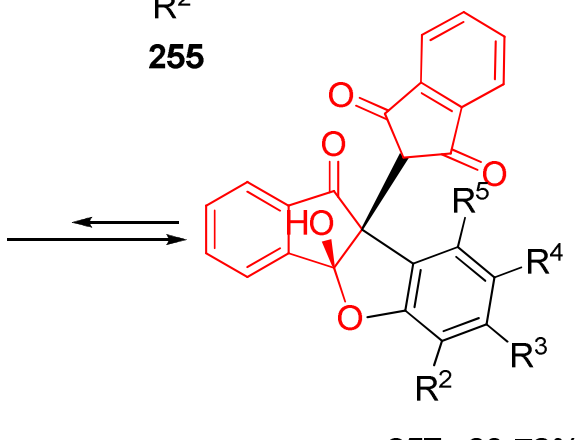

$$
\begin{aligned}
& \mathrm{R}^{1}=\mathrm{H}, \mathrm{Me}, \mathrm{OH} \\
& \mathrm{R}^{2}=\mathrm{H}, \mathrm{Me}, \mathrm{OMe}, \mathrm{Cl}, \mathrm{COMe}, \mathrm{OH} \\
& \mathrm{R}^{3}=\mathrm{H}, \mathrm{OH} \\
& \mathrm{R}^{4}=\mathrm{H}, \mathrm{CH}(\mathrm{Me})_{2} \\
& \mathrm{R}^{5}=\mathrm{H}, \mathrm{Me} \\
& \mathrm{R}^{2}, \mathrm{R}^{3}=\text { benzofusion } \\
& \mathrm{R}^{4}, \mathrm{R}^{5}=\text { benzofusion }
\end{aligned}
$$

Scheme 78. Synthesis of 2-aryl/alkyl-2,2'-biindan-1,1',3,3'-tetrones in hemi-ketal forms.<smiles>O=C1c2ccccc2C(=O)C1C1(O)C(=O)c2ccccc2C1=O</smiles>

254<smiles>[R]c1ccc(O)cc1[R]</smiles>
204<smiles>[R]c1cc2c(cc1[R])C1(C(=O)c3ccccc3C1=O)C(C)(O)Oc1ccccc1C2=O</smiles>

259<smiles>[R]c1cc(O)c(C2(C3C(=O)c4ccccc4C3=O)C(=O)c3ccccc3C2=O)cc1[R]</smiles>

258

$\mathrm{R}^{1}=\mathrm{H}, \mathrm{Me}, \mathrm{I}$<smiles></smiles>

$260 \quad 62-82 \%$

Scheme 79. Condensation of para- or meta-substituted phenols with 2-hydroxy-2,2'- biindane$1,1^{\prime}, 3,3$ '-tetrone to prepare 2',4-spiro(1',3'-indanedione)-indeno[3,2-b]chromenes. 
Synthesis of alkylated compounds at the hemiketal part of ninhydrin-phenol adducts was selectively achieved by using an iodine-alcohol system (Scheme 80). ${ }^{312}$ Recently, this reaction was performed for an extended time to prepare various substituted $3 H, 3^{\prime} H$-spiro[benzofuran-2, $1^{\prime}-$ isobenzofuran]-3,3'-diones $\mathbf{2 6 3}$ (racemic) showing preferential inhibition of influenza virus type B over type $\mathrm{A}^{307}$<smiles>[R]c1ccc(O)cc1[R]</smiles>

204<smiles>O=C1c2ccccc2C(=O)C1(O)O</smiles><smiles>CC(C)=O</smiles><smiles>[R]c1cc2c(cc1[R])C1(O)OC2(O)C(=O)c2ccccc21</smiles>
$\mathrm{I}_{2}$ (2 equiv.) MeOH, reflux $13-36 \mathrm{~h}$ 261<smiles></smiles>

$$
\begin{aligned}
& \mathrm{R}^{1}=\mathrm{R}^{2}=\mathrm{H} \\
& \mathrm{R}^{1}=\mathrm{H}, \mathrm{R}^{2}=\mathrm{CH}_{3} \\
& \mathrm{R}^{1}=\mathrm{CH}_{3}, \mathrm{R}^{2}=\mathrm{H} \\
& \mathrm{R}^{1}=\mathrm{H}, \mathrm{R}^{2}=\mathrm{OH}
\end{aligned}
$$

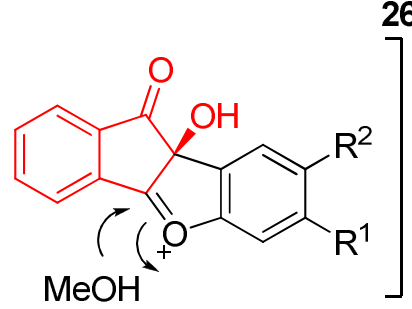<smiles>[R]c1cc2c(cc1[R])C1(O)OC3(OC)c4cc(C)ccc4C(=O)C3(O)OC21</smiles>

262

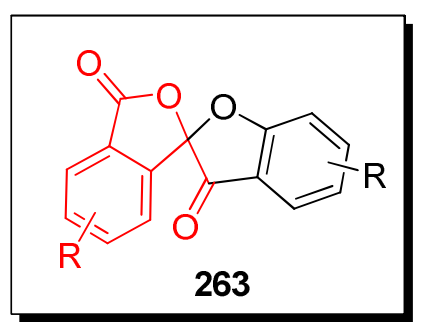

Scheme 80. Mechanism proposed to explain the Synthesis of alkylated compounds at the hemiketal part of ninhydrin-phenol adducts.

It was reported that when $\mathrm{Pb}(\mathrm{OAc})_{4}$ was added to a mixture of benzylamine 156, alkyl propiolates 47, and ninhydrin 1, the corresponding diasteriomereric isobenzofurans 265 are achieved in excellent yields (Scheme 81). ${ }^{313}$ The ${ }^{1} \mathrm{H}$ NMR spectrum of products 265 indicated a mixture of two diastereoisomeric $(E)$ - and $(Z)$-compounds. 


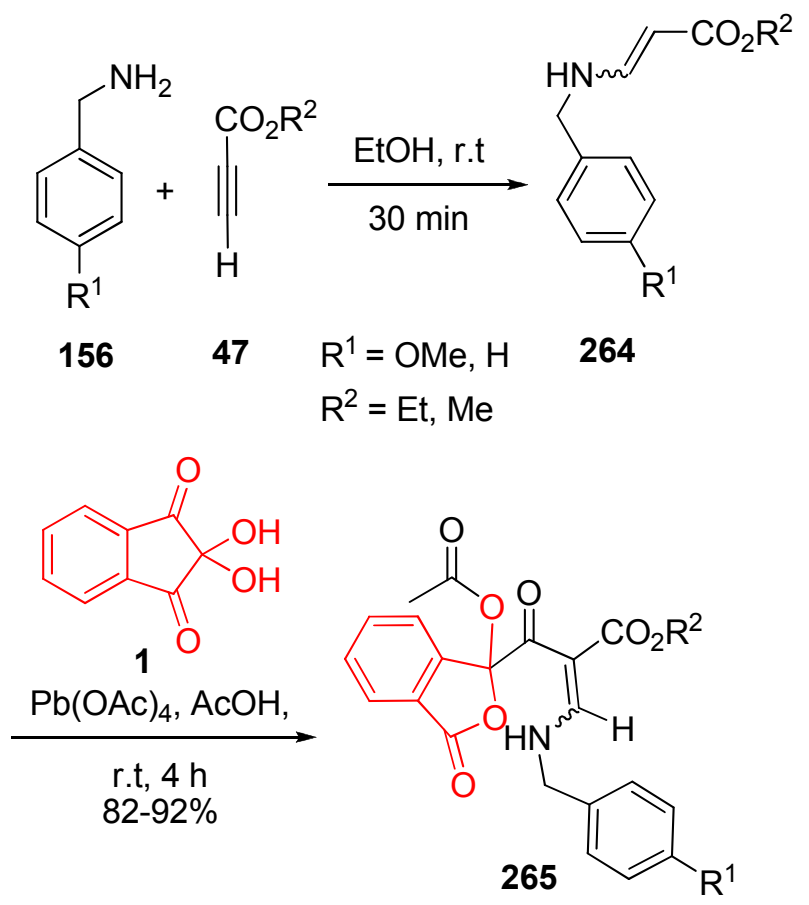

Scheme 81. $\mathrm{Pb}(\mathrm{OAc})_{4}$ mediated reaction of benzylamine, alkyl propiolates, and ninhydrin.

Kim and co-workers reported the reaction of ninhydrin $\mathbf{1}$ and 1,3-cyclohexane dione $\mathbf{7 4}$ in iodine and methanol leading to the aromatization of the 1,3-cyclohexane ring, with both products 267 and 268 being isolated (Scheme 82). ${ }^{314}$ In a similar study, Mehdi's group reported this reaction in glacial acetic acid on simple heating for $15 \mathrm{~min}$. The compound showed potential antimicrobial activity comparable to that of clinically used antimicrobial agents against selected microorganisms. It also exhibited selective and moderate inhibitory activity of the butyryl cholinesterase enzyme. ${ }^{315}$

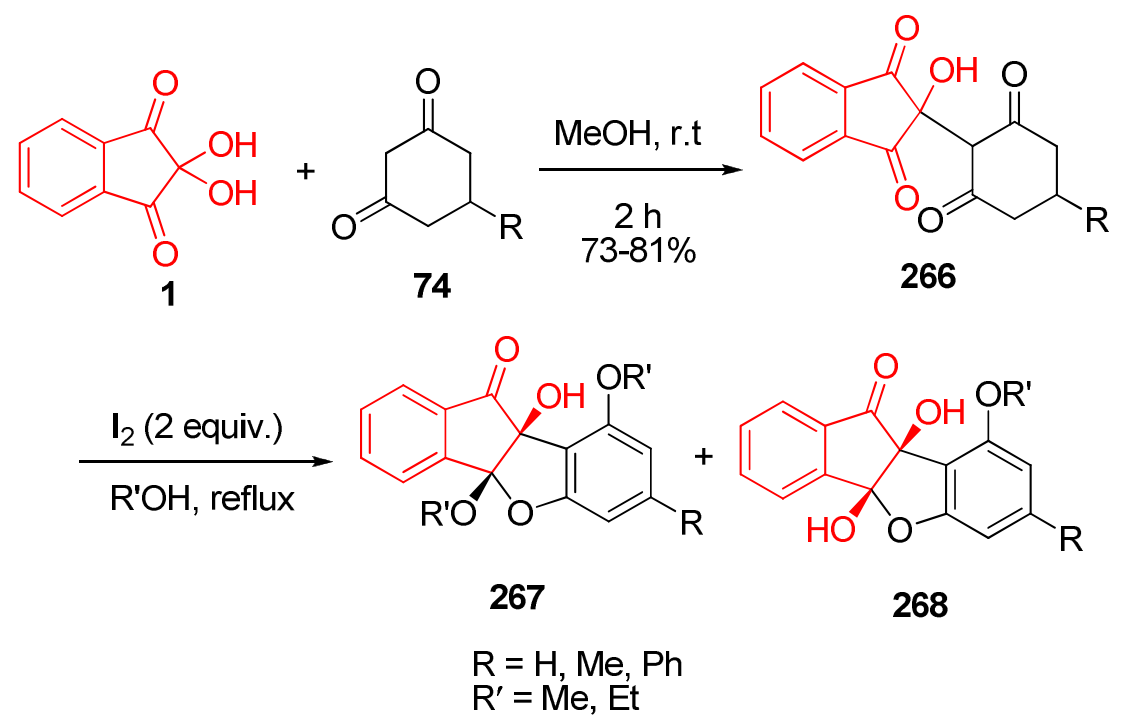

Scheme 82. The reaction of ninhydrin and 1,3-cyclohexane dione in iodine and methanol. 
In 2011, Campagna and co-workers explored the reactivity of several hydroxyarenes $\mathbf{2 6 9}$ with ninhydrin in a 1:1 molar ratio using $\mathrm{AcOH}$ as both the solvent and the catalyst at $60{ }^{\circ} \mathrm{C}$ (Scheme 83). ${ }^{316}$ Mono-, 1,3-di-, and 1,3,5-trihydroxyarenes [phenol 269d, resorcinol 269c, and phloroglucinol 269a] were used as hydroxyarenes and as expected, the reaction rate rose with increasing electron density of the arene.<smiles>O=C1c2ccccc2C(=O)C1(O)O</smiles>

1<smiles>[X]c1cc([Y])cc(O)c1</smiles>

269<smiles>[Y]c1cc([X])c2c(c1)O[C@]1(O)c3ccccc3C(=O)[C@@]21O</smiles>

270

$$
\begin{aligned}
& \text { 269a } X=Y=O H \\
& \text { 269b } X=Y=O M e \\
& \text { 269c } X=H, Y=O H \\
& \text { 269d } X=Y=H
\end{aligned}
$$

$$
\begin{aligned}
& \text { 270a } X=Y=O H \\
& \text { 270b } X=Y=O M e \\
& \text { 270c } X=H, Y=O H \\
& \text { 270d } X=Y=H
\end{aligned}
$$

racemate

Scheme 83. AcOH-mediated reaction of hydroxyarenes with ninhydrin.

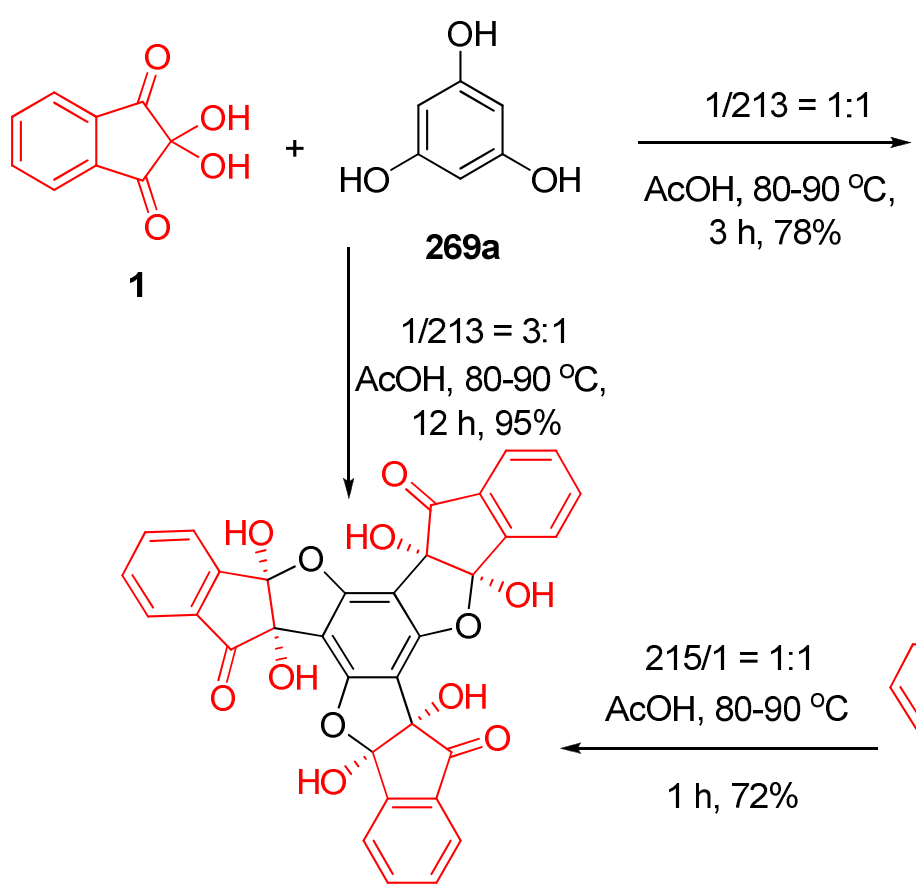

Bowl compound 272

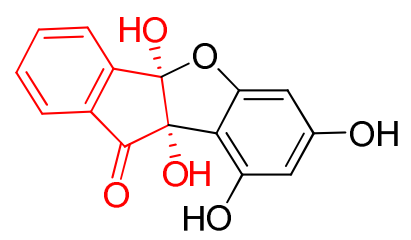

mono-adduct 270a

$$
\begin{gathered}
214 / 1=1: 1 \\
\mathrm{AcOH}, 80-90^{\circ} \mathrm{C}, \\
2 \mathrm{~h}, 73 \%
\end{gathered}
$$

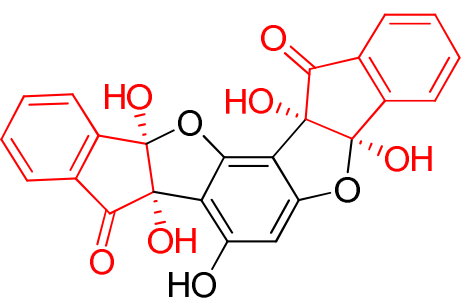

bis-adduct 271

Scheme 84. Synthesis of a new bowl-shaped compound reported by Kim.

Kim's group used an innovative strategy to synthesize a new bowl-shaped compound 272 in excellent yield by a simple one-pot reaction from the reaction of three ninhydrin molecules with one 
molecule of phloroglucinol 269a in acetic acid (Scheme 84). ${ }^{317}$ Later, the effectiveness of Kim's synthetic route for other vicinal polycarbonyl compounds, with the goal of producing similar molecular containers, was studied. ${ }^{318}$ In this regard, a scissors-shaped compound, 2,2-bis(4hydroxy-3-phenylphenyl)-1H-indene-1,3(2H)-dione 273 (Figure 3) was prepared as a new host species for crystalline host-guest complexes, and afforded complexes of 1:1 host-to-guest ratio with acetone, EtOH, and $\mathrm{CH}_{2} \mathrm{Cl}_{2}$, and a 2:3 complex with benzene. ${ }^{319}$

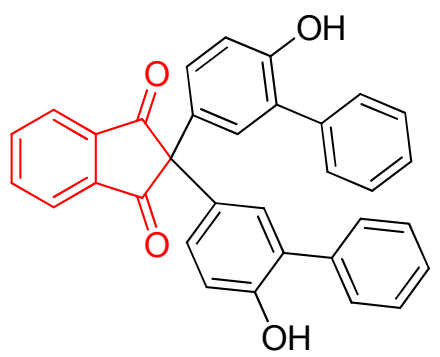

273

Figure 3. Structure of compound 273.

According to the procedure described by Das et al., refluxing 206 in ethylene glycol with a catalytic amount of triethylamine affords benzofuroisocoumarins 274 (Scheme 85). ${ }^{320}$

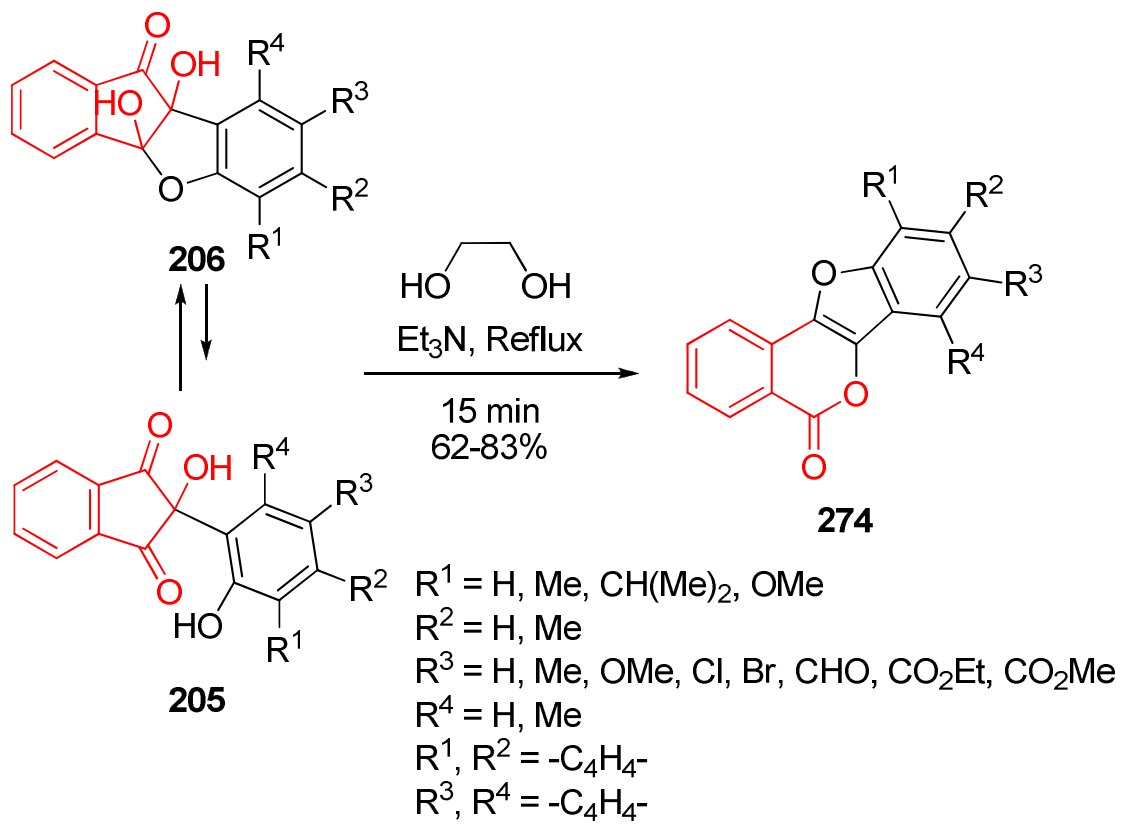

Scheme 85. Synthesis of benzofuroisocoumarins reported by Pramanik.

It is noteworthy that ninhydrin produces 2,2-diaryl-1,3-indanediones $\mathbf{2 7 5}$ during the reaction of hydroxyalkylation in $\mathrm{H}_{2} \mathrm{SO}_{4}$ media, while 2,2-diaryl-1,3-indanediones $\mathbf{2 7 5}$ are not stable in the 
presence of trifluoromethanesulfonic acid (TFSA) due to isomerization to 3(diarylmethylene)isobenzofuranones 277. ${ }^{321-322}$ It was suggested that the difference between sulfuric acid and TFSA is the ability of TFSA to generate a diprotonated reactive intermediate 276, which is then transformed into isomerization product $\mathbf{2 7 7}$. The mechanism proposed for the conversion of $\mathbf{1}$ to 277 is described in Scheme 86. Reflux of 275 in ethylene glycol with a catalytic amount of triethylamine also afforded $\mathbf{2 7 7}$ in very good yields. ${ }^{323}$

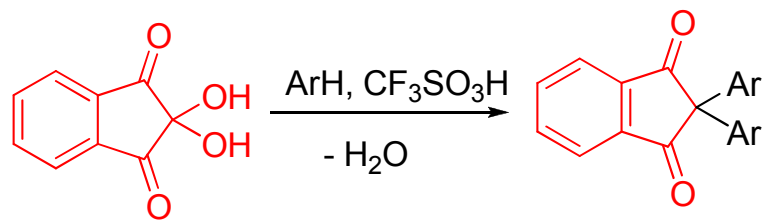

1

275

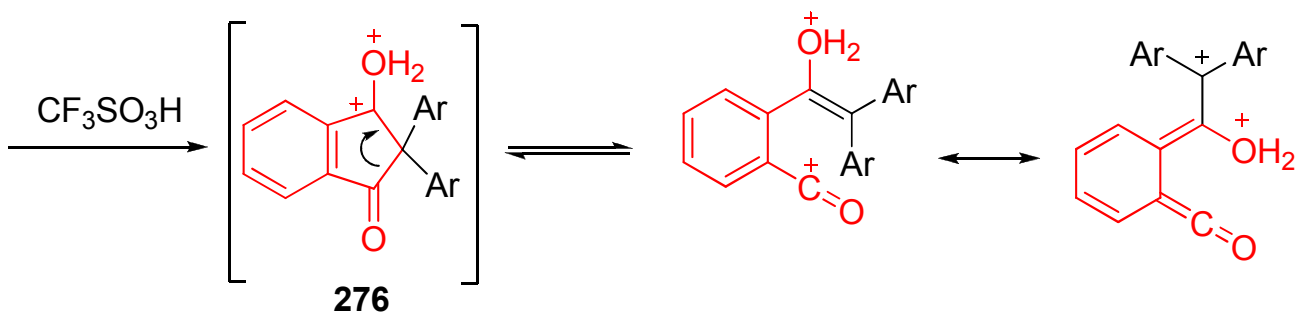<smiles>CC#CC#Cc1ccc2c(c1C(=O)O)C(=O)OC2=C(Br)Br</smiles>

Scheme 86. Mechanistic explanation of the isomerization of 2,2-diaryl-1,3-indanediones to 3(diarylmethylene)isobenzofuranones.

In related studies, it was found that $\mathbf{2 7 5}$ on stirring with ethylenediamine ${ }^{323-324}$ or phenylmagnesium bromide ${ }^{325}$ furnished the products diarylmethanes and 1,1-diphenyl-3diphenylmethylenedihydroisobenzofuran 279, respectively (Scheme 87). 
<smiles>O=C1c2ccccc2C(=O)C1(Br)Br</smiles>

275

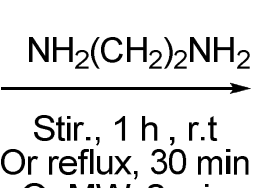

Or MW, 2 min<smiles>NCCN1C(=O)c2ccccc2C1=O</smiles>

278

$\mathrm{Ar}=\mathrm{Ph}, p-\mathrm{FC}_{6} \mathrm{H}_{4}, p-\mathrm{ClC}_{6} \mathrm{H}_{4}, p-\mathrm{BrC}_{6} \mathrm{H}_{4}, p-\mathrm{IC}_{6} \mathrm{H}_{4}$, $p-\mathrm{OMeC}_{6} \mathrm{H}_{4}, 2,4-(\mathrm{OMe})_{2} \mathrm{C}_{6} \mathrm{H}_{3}, 2,3,4-(\mathrm{OMe})_{3} \mathrm{C}_{6} \mathrm{H}_{2}$<smiles>O=C1c2ccccc2C(=O)C1(c1ccccc1)c1ccccc1</smiles>

275a

Scheme 87. Reaction of ethylenediamine or phenylmagnesium bromide with 275.

It was found that acetoacetanilide $\mathbf{2 8 0}$ undergoes heterocyclization to indenofuran $\mathbf{2 8 1}$ or indenopyrrole $\mathbf{2 8 2}$ upon treatment with ninhydrin under two different conditions: stirring in ethanol at room temperature, and refluxing ethanol, respectively (Scheme 88). ${ }^{326}$ The milder reaction provided better yield.

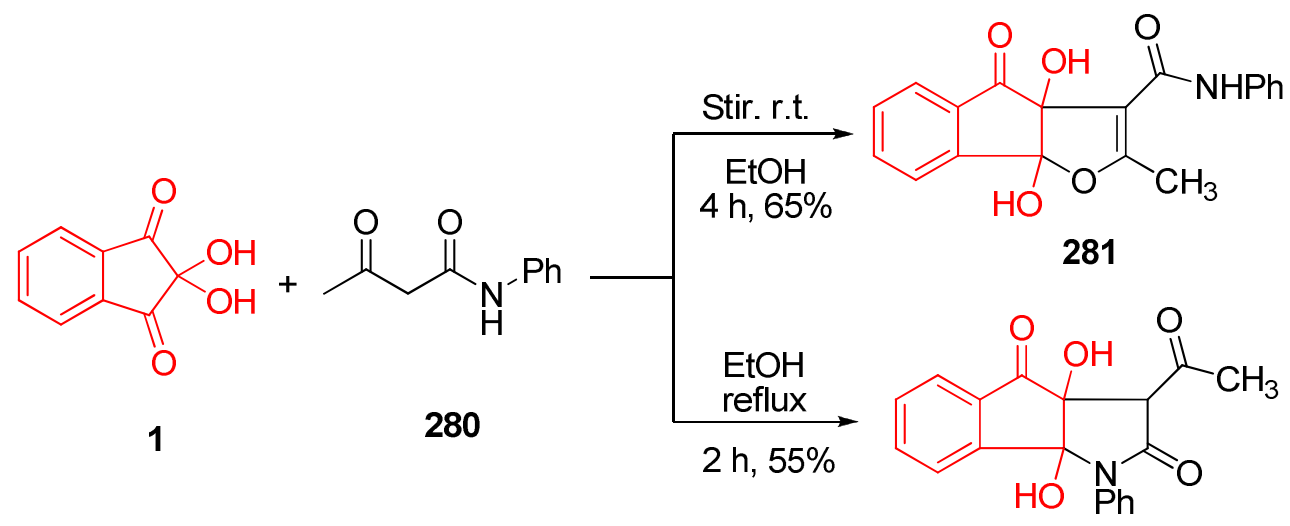

282

Scheme 88. Synthesis of indenofuran or indenopyrrole from acetoacetanilide and ninhydrin.

3.2.4. Dioxolanes. Dioxolans are attracting a growing interest due to their use as precursors to a variety of synthetic targets. ${ }^{327}$ Dioxolane nucleus is also a prominent structural motif found in synthetic compounds with vital medicinal value. ${ }^{328-330}$ In 1985, Yalpani and Wilke reported that the products formed in the reaction of ninhydrin with silylating agents varied depending on the silylating agent used. ${ }^{331}$ Thereafter, in another strategy, treatment of ninhydrin $\mathbf{1}$ with 
chlorotrialkylsilane allows for access to a racemic silylated ninhydrin dimer $\mathbf{2 8 4}$ accompanied with bis(trialkylsilyloxy) derivatives $\mathbf{2 8 3}$ (Scheme 89). ${ }^{332}$

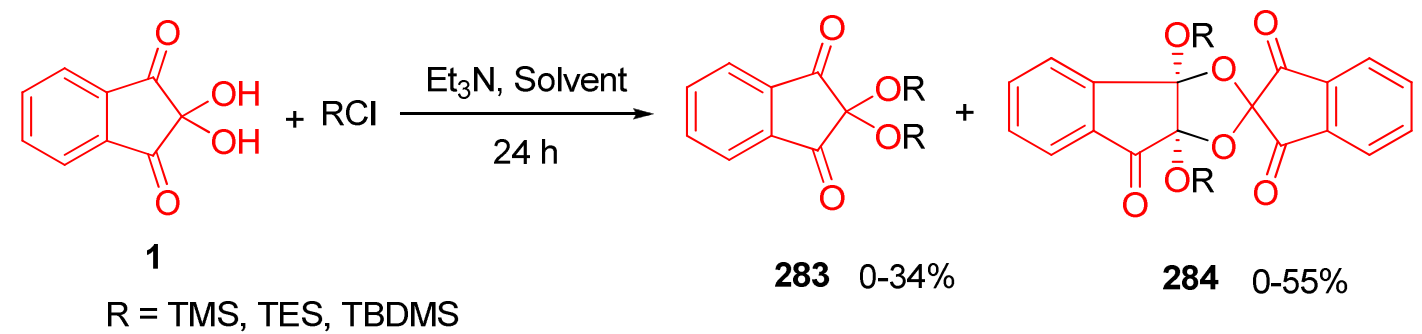

Scheme 89. Synthesis of silylated ninhydrin dimer and bis(trialkylsilyloxy) derivatives.

Shaabani and co-workers investigated the reaction of isocyanides 285 with two equivalent of ninhydrin 1 under refluxing conditions in chloroform to give $\mathrm{C}_{\mathrm{s}}$ symmetry (meso) dispiro iminodioxolanes 286 in fairly high yields. ${ }^{333}$ A possible mechanism was proposed by them and is presented in Scheme 90.

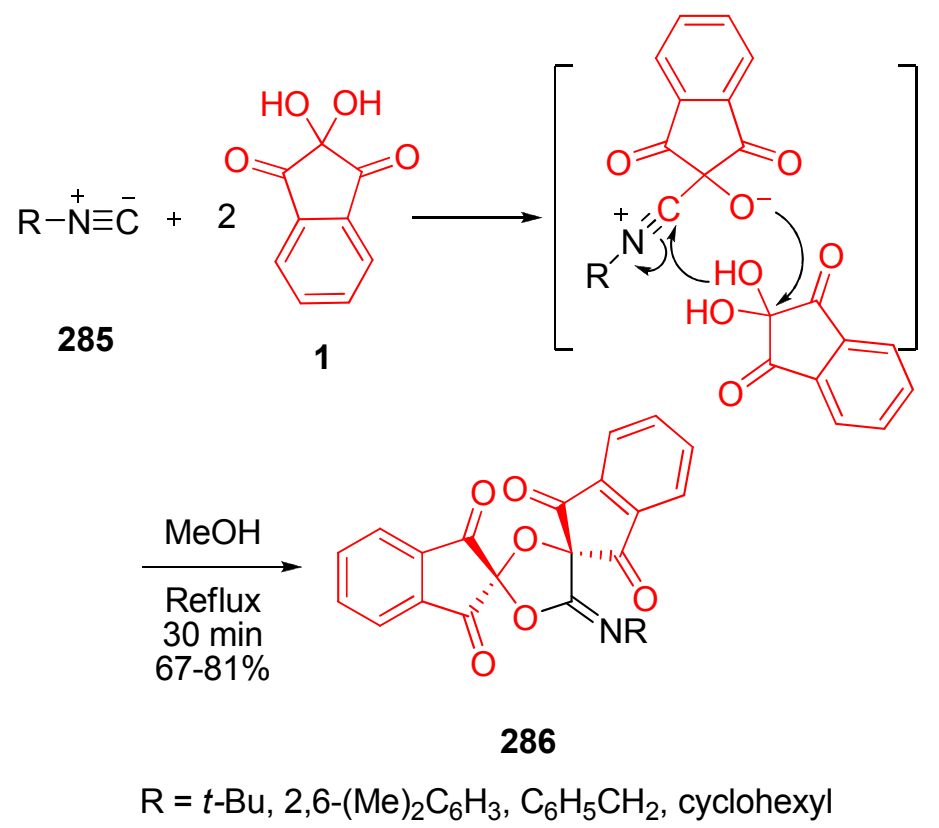

Scheme 90. Mechanism proposed to explain the reaction of isocyanides with two equivalent of ninhydrin.

Spiro compounds 287 were obtained from the reaction of 1 with 2-bromoethanol and 3bromopropanol 6, respectively (Scheme 91) ${ }^{266}$ 


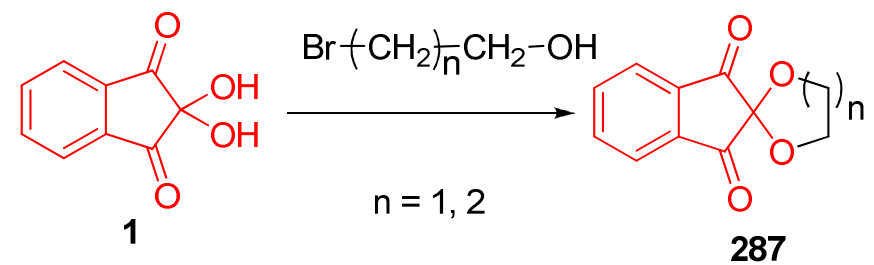

Scheme 91. Reaction of ninhydrin with 2-bromoethanol and 3-bromopropanol.

Investigations by Butenschon and co-workers showed that ninhydrin is interchangeably converted to either ketal intermediates $\mathbf{2 8 8}$ or $\mathbf{2 8 7}$, of which both are leading to 1,2,3tris(ethylenedioxy)indane 289, the route via $\mathbf{2 8 7}$ giving higher yield (Scheme 92). ${ }^{334}$ In a related study, they found that the photolytic decarbonylation of $\mathbf{2 8 8}$ occurs smoothly during irradiation to give 290. Deprotection of $\mathbf{2 9 0}$ results in the formation of 1,2-dioxobenzocyclobutene $\mathbf{2 9 1}$ in quantitative yield (Scheme 93). ${ }^{335}$<smiles>O=C1c2ccccc2C(=O)C1(O)O</smiles>
1

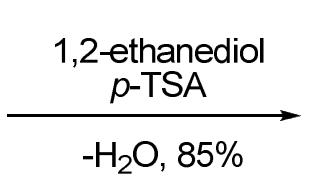<smiles>CCC</smiles><smiles>O=C1c2ccccc2C(=O)C12OCCO2</smiles>

288

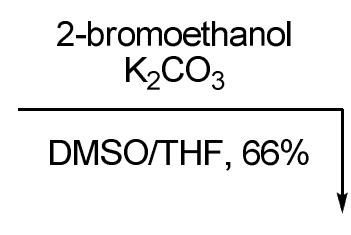<smiles>c1ccc2c(c1)C1(OCCO1)C1(OCCO1)C21OCCO1</smiles>

289<smiles>O=C1c2ccccc2C(=O)C1(O)O</smiles><smiles>[R6]OC(=O)OCC(C)C(=O)O[Na]</smiles>

DMSO/THF, 66\%<smiles>O=C1c2ccccc2C(=O)C12OCCO2</smiles>

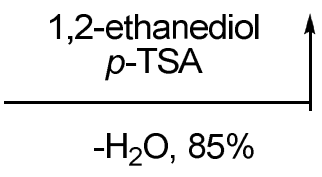

287

Scheme 92. Synthetic routes to tris(ethylenedioxy)indane.<smiles>O=C1C2(OCCO2)c2ccccc2C12OCCO2</smiles>

288

政<smiles>[IH2]</smiles>

$48 \%$

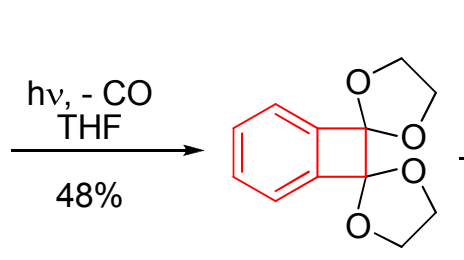

290<smiles>Cc1ccc([N+](=O)[O-])cc1</smiles>

291

Scheme 93. Synthesis of 1,2-dioxobenzocyclobutene. 
More recently, the same group described irradiation of 1,3-bis(ethylenedioxy)-2-indanone $\mathbf{2 8 8}$ with a number of dienophiles, such as dimethyl fumarate/ propenal/ butenone/ dimethyl butynedioate/ maleic anhydride/ acrylonitrile, which results in the formation of cycloadducts 292298 (Scheme 94). ${ }^{336}$

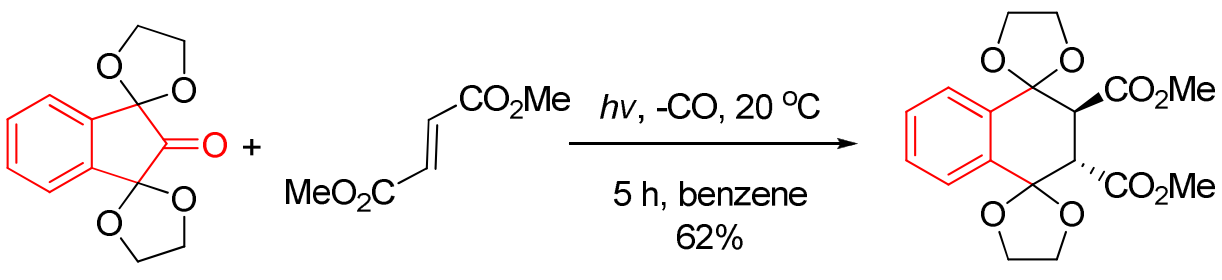

288

rac-292<smiles>O=CC1CC2(OCCO2)c2ccccc2C12OCCO2</smiles>

rac-293<smiles></smiles>

rac-296<smiles>CC(=O)C1CC2(OCCO2)c2ccccc2C12OCCO2</smiles>

rac-294<smiles>N#CC1CC(=O)C2(OCCO2)c2ccccc2C12OCCO2</smiles>

rac-297<smiles>COC(=O)C1=C(C(=O)OC)C2(OCCO2)c2ccccc2C12OCCO2</smiles>

rac-295<smiles>N#CC1CC2(OCCO2)c2ccccc2C2(OCCO2)C1=O</smiles>

rac-298

Scheme 94. Irradiation of 1,3-bis(ethylenedioxy)-2-indanone with a number of dienophiles to form various cycloadducts.

\subsection{S-Heterocyclic compounds}

3.3.1. Thiophenes. Nowadays thiophene derivatives in combination with other ring systems have been extensively used in pharmaceutical applications such as anti-allergic, ${ }^{337}$ analgesic, ${ }^{338}$ antiinflammatory, ${ }^{339}$ antibacterial $^{42}$ and ocular hypotensive activities. ${ }^{340}$ The reaction of ninhydrin $\mathbf{1}$ with benzo[b]thiophene $\mathbf{2 9 9}$ in acetic acid, in the presence of a small amount of sulfuric acid as a catalyst, afforded a novel fluorenone compound fused to benzo[b]thiophene rings $\mathbf{3 0 3}$ (Scheme 95). ${ }^{341}$ 
<smiles>O=C1c2ccccc2C(=O)C1(O)O</smiles><smiles>C[C@@H]1Sc2ccccc2C1C1Sc2ccccc2C(=O)C1=C1Sc2ccccc2C1=O</smiles>

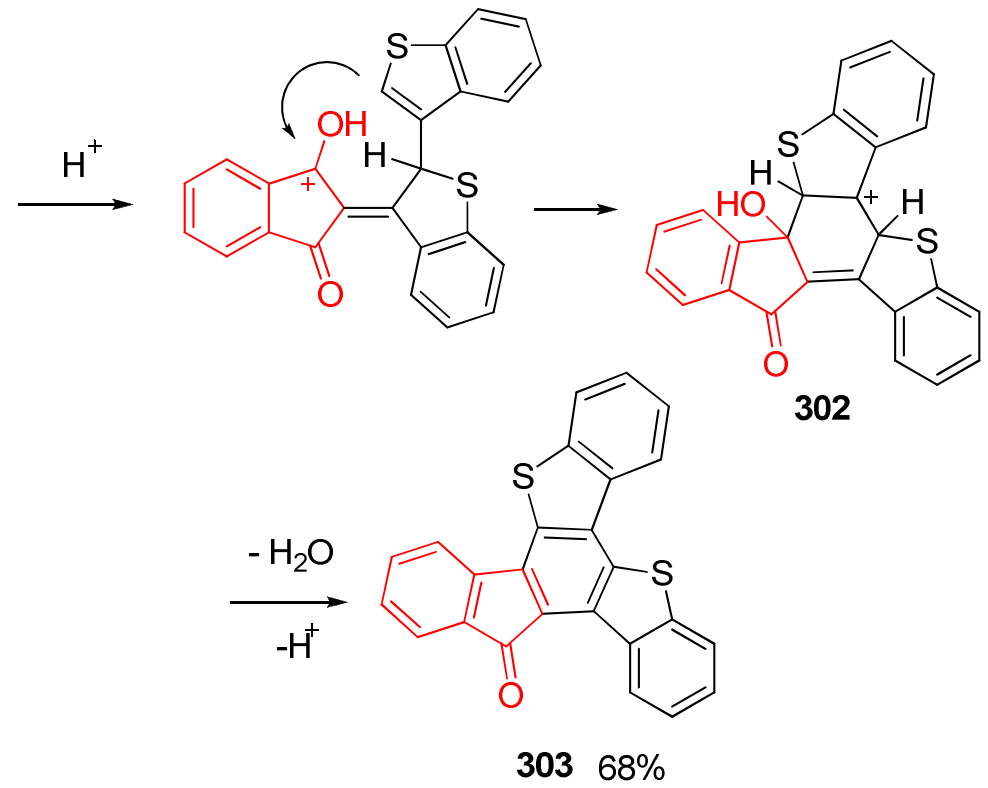

Scheme 95. Mechanism that explains the catalytic synthesis of fluorenone compound fused to benzo[ $[b]$ thiophene rings.

Harrison et al. found that a mixture of thiophene in aqueous sulfuric acid $(75 \% \mathrm{v} / \mathrm{v})$ and ninhydrin produces low yields of three products $(304,306$ and 307): firstly, the typical reaction of a ketone with thiophene produces the dithienyldiketone 304 (minor observed product, $0.8 \%$ ), which experiences acid-induced rearrangement to the diastereomeric diol intermediate 305 . Secondary, the dehydration of this yields the pentacyclic ketone $306(0.5 \%)$, and the third, the major product is the tetraketone 307 (7\%) (Scheme 96). ${ }^{342}$ 
<smiles>O=C1c2ccccc2C(=O)C1(O)O</smiles>

1<smiles>O=C1C(=c2ccc(=C3C(=O)c4ccccc4C3=O)s2)C(=O)c2ccccc21</smiles>

$3077 \%$<smiles>O=C1c2ccccc2C(=O)C1(c1cccs1)c1cccs1</smiles>

$3040.8 \%$<smiles>O=C1c2ccccc2C(O)(c2cccs2)C1(O)c1cccs1</smiles>

305<smiles>O=C1c2ccccc2-c2c1c1sccc1c1ccsc21</smiles>

$306 \quad 0.5 \%$

Scheme 96. Reaction of a mixture of thiophene and ninhydrin reported by Musgrave.

\subsection{N,O-Heterocyclic compounds}

3.4.1. Oxazolidines. The chemistry of oxazolidine and its derivatives has received considerable attention owing to their synthetic and biological importance. ${ }^{343}$ The oxazolidine moiety has been incorporated into a wide variety of therapeutically interesting compounds that have antibacterial, ${ }^{344-}$ 345 anti-inflammatory ${ }^{346}$ and anti-mycobacterial activities. ${ }^{347}$ Mohammadizadeh and Firoozi reported a one-pot procedure involving the addition of lead tetraacetate to a mixture of ninhydrin 1 and urea 191 for the synthesis of racemic spiroisoindoline-1,5'-oxazolidine derivatives $\mathbf{3 0 8}$ (Scheme 97). ${ }^{348}$

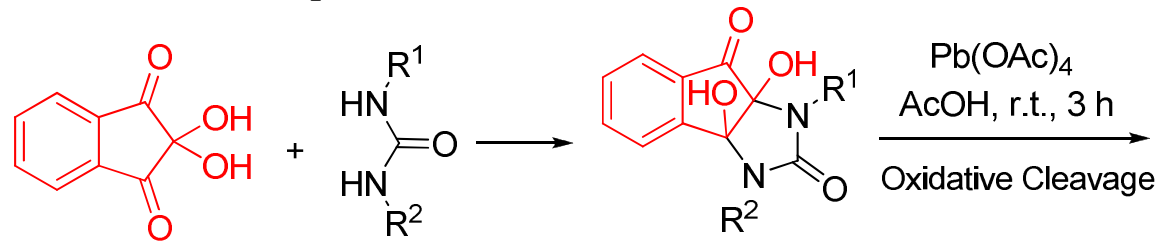

1

191

192

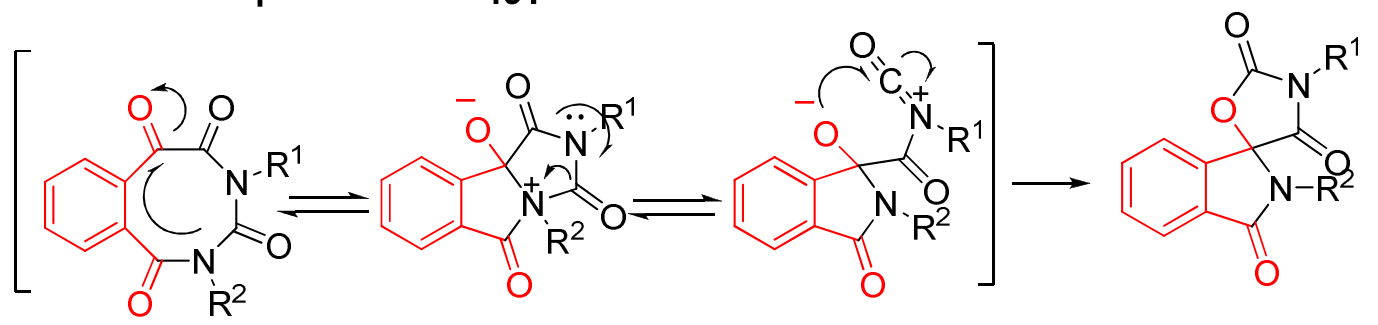

308

$73-84 \%$<smiles>CNC(=O)NCc1ccccc1</smiles>

Scheme 97. Mechanism that accounts for the formation of spiroisoindoline-1,5'-oxazolidines. 


\subsection{N,S-Heterocyclic compounds}

3.5.1. Thiazolidines. Thiazolidines and their derivatives are found to be associated with various biological activities such as anti-inflammatory, ${ }^{349}$ antibacterial $^{350}$ and anti-HIV activities. ${ }^{351}$ The thiazolidine ring has been also used as scaffold to develop novel class of anticancer agents with a broad spectrum of cytotoxicity against many human cancer cells. ${ }^{352-354}$ While all $\alpha$-amino acids, with the exception of cysteine and related compounds, react with ninhydrin to give Ruhemann's purple, in 1951, Kuhn and Hammer were the first group to report the anomalous behaviour of cysteine 309 in terms of preferential formation of a colourless condensation product, proposing 310 (Scheme 98). ${ }^{355}$ Later on, Prota and Ponsiglione examined the chemical and spectroscopic evidence, leading to the conclusion that product has in fact the meso isomeric spirane structure $\mathbf{3 1 1}{ }^{356}$

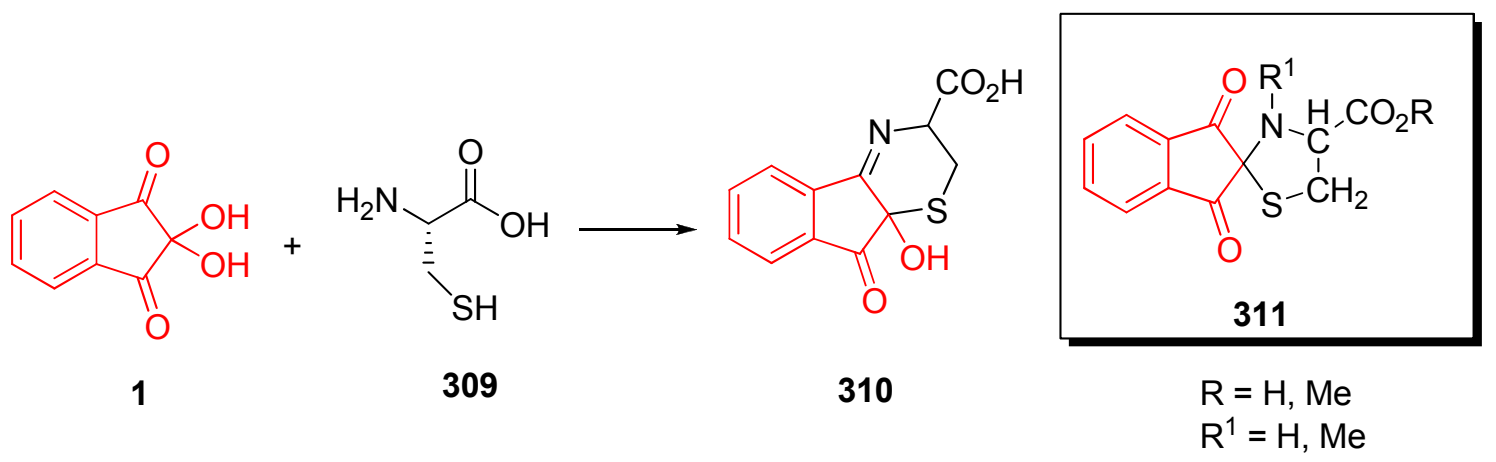

Scheme 98. Condensation of cysteine with ninhydrin.

Spirocyclization of D-penicillamine $\mathbf{3 1 2}$ with ninhydrin to form the spirothiazolidine compound 1,3-dioxo-4'-carboxy-5',5'-dimethylspiro[indane-2,2'-thiazolidine] 313 was studied (Scheme 99). ${ }^{357}$ Using the D-penicillamine archetype 312, attachment of this compound via a disulfide bond onto thiol-reactive solid prior to the reaction with ninhydrin allowed for spectrophotometrical monitoring of the supernatant at $570 \mathrm{~nm}$. In this regard, Sotgia and co-workers developed a new HPLC method by fluorescence or UV/vis absorbance detection to separate and quantify penicillamine stereoisomers after their spirocyclization with ninhydrin. ${ }^{358-359}$<smiles>O=C1c2ccccc2C(=O)C1(O)O</smiles>

1<smiles>CC(C)(S)C(N)C(=O)O</smiles>

312

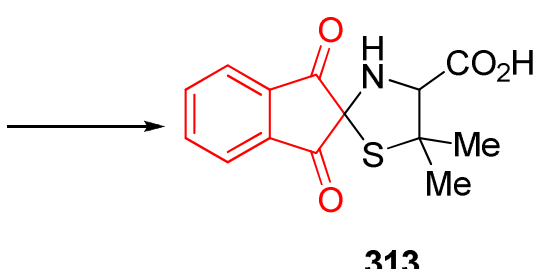

313

Scheme 99. Spirocyclization of D-penicillamine with ninhydrin reported by Rojanarata. 
Very recently, a powerful chemo-/regioselective synthesis of oxathiaza[3.3.3]propellane derivatives 314 was achieved by means of a sequential four-component reaction involving ninhydrin 1, malononitrile, primary amines, and aryl isothiocyanates 196 (Scheme 100). ${ }^{360}$

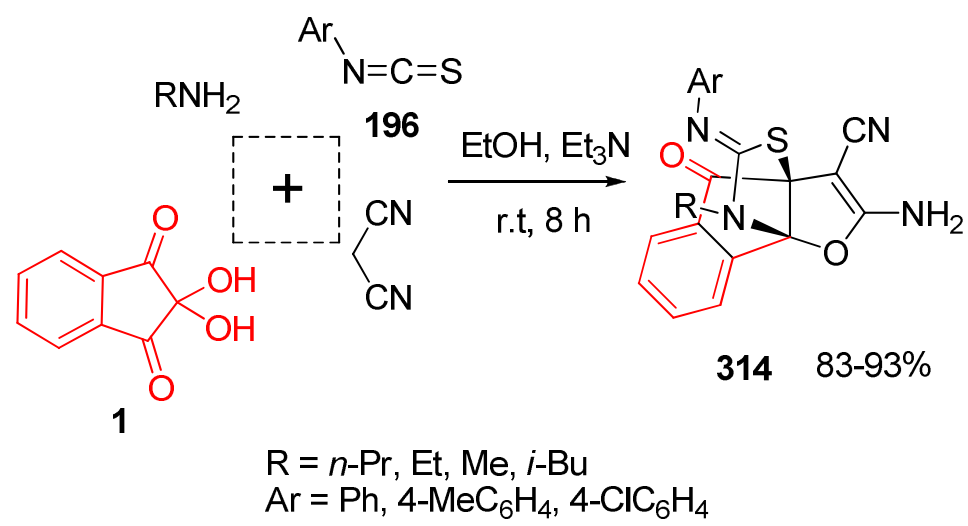

Scheme 100. Four-component synthesis of oxathiaza[3.3.3]propellanes from ninhydrin, malononitrile, primary amines, and aryl isothiocyanates.

\section{Synthesis of Six-membered Heterocycles}

In the previous section, we summarized the use of ninhydrin for the synthesis of five-membered heterocycles. This section describes examples of successful application of ninhydrin in the synthesis of various six-membered heterocycles. Pyridines, pyrimidines, pyrazines, quinoxalines, tetrahydroquinolines, triazines, pyrans, dioxanes, oxazines, and oxathianes are among the heterocyclic scaffolds that are presented in this section.

\subsection{N-Heterocyclic compounds}

4.1.1. Pyridines and piperidines. Pyridines are among the most frequently cited heterocyclic compounds. The pyridine structure is found in various therapeutic agents, including anti-malarial, ${ }^{361}$ anti-osteoporotic, ${ }^{362}$ anti-inflammatory, ${ }^{363}$ anticancer, ${ }^{364-365}$ antifungal ${ }^{366}$ and other pharmaceutical compounds. Additionally, the piperidines and their analogues are important heterocycles that are present in many naturally occurring alkaloids ${ }^{367-368}$ and biologically active synthetic molecules. ${ }^{369-}$ 370 An efficient synthetic procedure for functionalized heterocyclic[3.3.3]propellanes $\mathbf{3 1 5}$ was successfully developed via a one-pot domino reaction of ninhydrin 1, malononitrile with 3arylamino-2-cyclohexenones and their 5,5-dimethyl derivatives $\mathbf{7 5}$ in the presence of triethylamine in ethanol at room temperature (Scheme 101). ${ }^{371}$ In the same report, a similar one-pot reaction using 3-arylamino-2-cyclopentenones $\mathbf{3 1 6}$ resulted in the functionalized spiro[cyclopenta[b]pyridine-4,2'indenes] 317 (Scheme 102). 
<smiles>O=C1c2ccccc2C(=O)C1(O)O</smiles>

1
$\mathrm{NC} \smile \mathrm{CN}$<smiles>[R]C1([R])CC(=O)C=C(N[Al])C1</smiles>

75

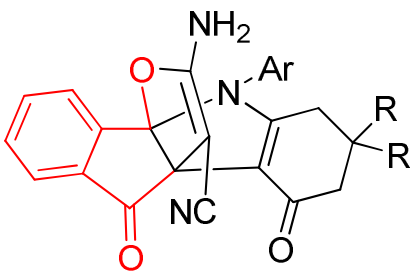

315

$\mathrm{R}=\mathrm{H}, \mathrm{Me}$

$\mathrm{Ar}=p-\mathrm{MeC}_{6} \mathrm{H}_{4}, p-\mathrm{OMeC}_{6} \mathrm{H}_{4}, o-\mathrm{OMeC}_{6} \mathrm{H}_{4}, \mathrm{C}_{6} \mathrm{H}_{5}, p-\mathrm{ClC}_{6} \mathrm{H}_{4}$, $m-\mathrm{ClC}_{6} \mathrm{H}_{4}, p-\mathrm{BrC}_{6} \mathrm{H}_{4}, \mathrm{C}_{6} \mathrm{H}_{4} \mathrm{CH}_{2}, p-\mathrm{NO}_{2} \mathrm{C}_{6} \mathrm{H}_{4}$

Scheme 101. Three-component synthesis of functionalized heterocyclic[3.3.3]propellanes.

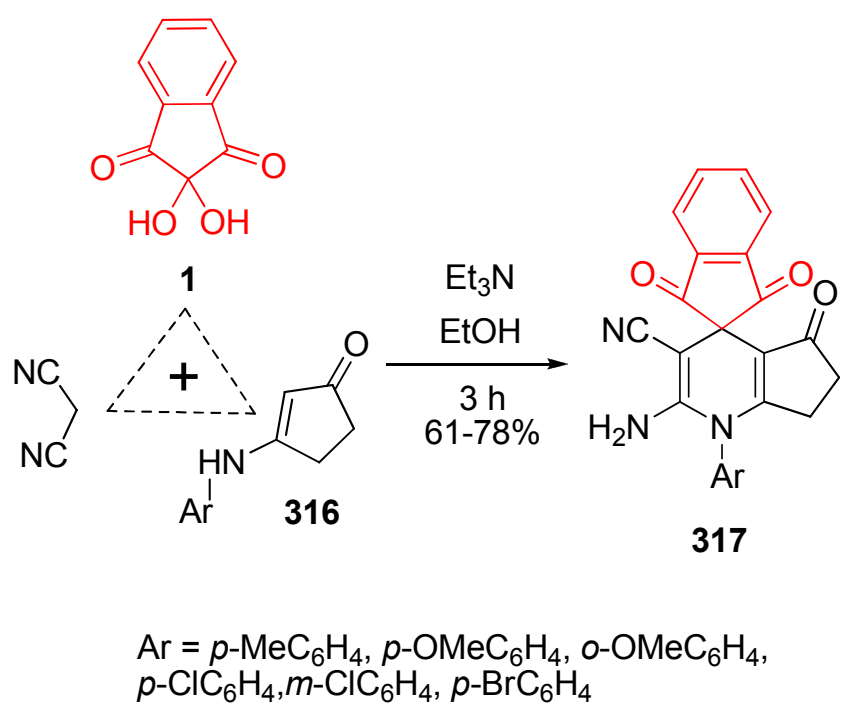

Scheme 102. Three-component synthesis of functionalized spiro[cyclopenta[b]pyridine- 4,2'indenes].

In an analogous way, the reaction of 1 with $m$-toluidine 318, malononitrile, and DMAD 41 yielded the spiro compound $\mathbf{3 1 9}$ in $77 \%$ yield (Scheme 103). ${ }^{372}$

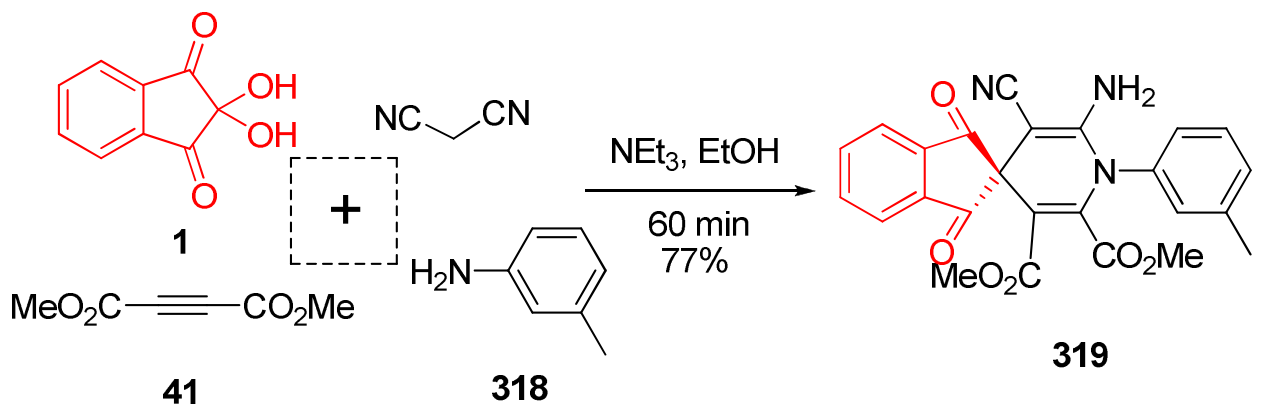

Scheme 103. Four-component reaction of ninhydrin, $m$-toluidine, DMAD, and malononitrile. 
The reactivity pattern of 2 moles of 6-amino-1,3-dimethyluracil $\mathbf{8 0}$ with ninhydrin $\mathbf{1}$ in ethanol at reflux temperature, as well as under microwave-assisted conditions in the solid state, was investigated. ${ }^{373}$ The reaction was found to proceed in a smooth manner, providing spiro pyridodipyrimidines $\mathbf{3 2 0}$ in good yields (Scheme 104).

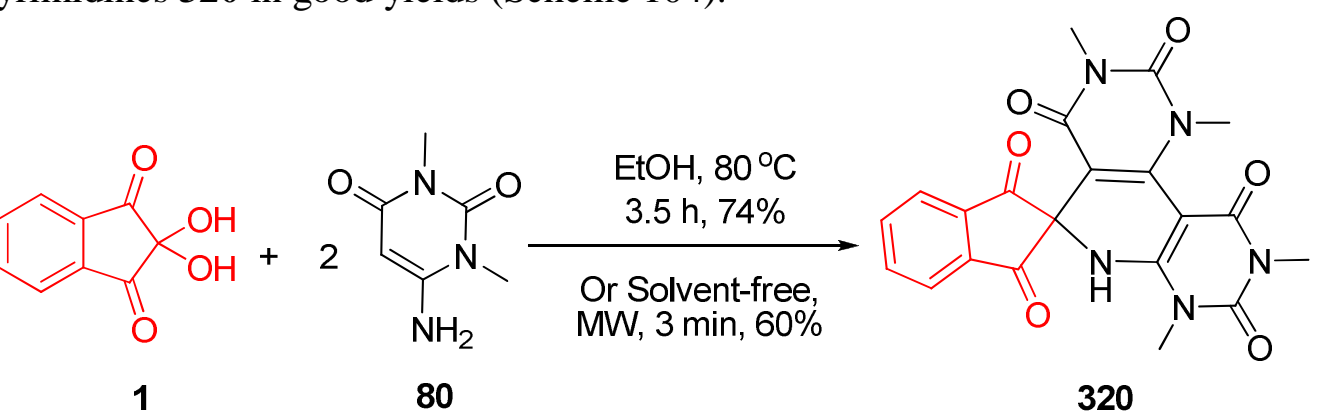

Scheme 104. Reaction of 2 moles of 6-amino-1,3-dimethyluracil with ninhydrin.

Condensation of ninhydrin 1, alkyl cyanoacetates 321 and 6-aminouracil derivatives 80 in refluxed ethanol facilitates the straight forward synthesis of pyrido[2,3- $d$ ]pyrimidine $(1 H, 3 H)-2,4-$ diones 324 in excellent yields (Scheme 105). ${ }^{374}$ The reaction occurs via initial formation of alkyl cyano(1,3-dioxoindan-2-ylidene)acetate 322. The latter is the condensation product of ninhydrin and alkyl cyanoacetate, which suffers nucleophilic attack by $\mathbf{8 0}$, followed by the loss of hydrogen cyanide to give aminoketone intermediate $\mathbf{3 2 3}$. The intermediate $\mathbf{3 2 3}$ then experiences cyclization to afford the product 324 .

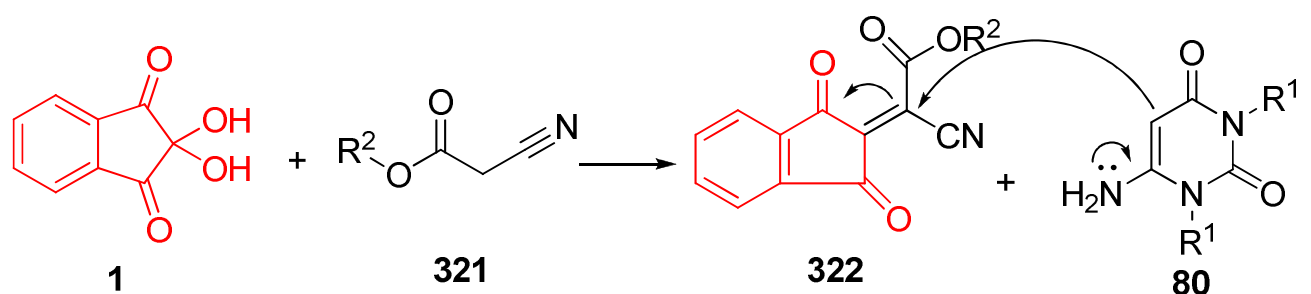<smiles>[R2]OC(=O)/C(=C1/C(=O)c2ccc(N=C)cc2C1=O)c1c(N)n([R17])c(=O)n([R16])c1=O</smiles>

323<smiles></smiles>

324

$$
\begin{aligned}
& \mathrm{R}^{1}=\mathrm{Me}, \mathrm{H} \\
& \mathrm{R}^{2}=\mathrm{Me}, \mathrm{Et}
\end{aligned}
$$

Scheme 105. Mechanism proposed for the synthesis of pyrido[2,3- $d]$ pyrimidine $(1 H, 3 H)-2,4$-diones. 
A one-pot and pseudo four-component synthesis of spiro-diindenopyridines $\mathbf{3 2 5}$ through the reaction of 1,3-indanedione $\mathbf{1 4}$ and ammonium acetate with ninhydrin was reported by Bazgir and co-workers (Scheme 106). ${ }^{375}$

2<smiles>O=C1CC(=O)c2ccccc21</smiles>

14
$\mathrm{NH}_{4} \mathrm{OAC}+$<smiles>CCC1(O)CCCCC1(O)O</smiles>

1

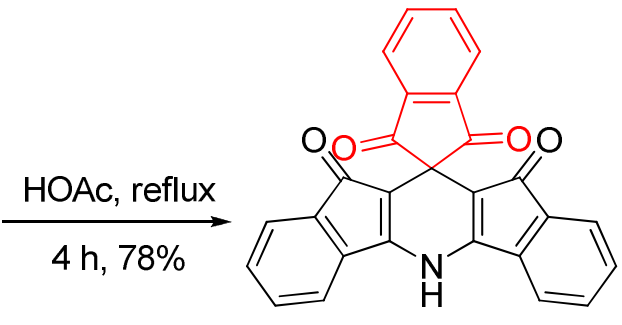

325

Scheme 106. Pseudo four-component synthesis of spiro-diindeno-pyridines.

In 1992, Neuzil and co-workers provided the biologically interesting yohimbanones 332, members of the Rauwolfia alkaloid family, directly from tryptophan 326a and ninhydrin. ${ }^{376}$ In 2003 , in investigations by Joullie and co-workers, L-tryptophan methyl ester 326b was subjected to the same reaction conditions. This reaction resulted in the isolation of intermediate $\mathbf{3 3 0}$ and its subsequent conversion to the yohimbane skeleton, which suggests that the reaction proceeds through a Pictet-Spengler mechanism, followed by an acid-mediated rearrangement (Scheme 107). ${ }^{377}$

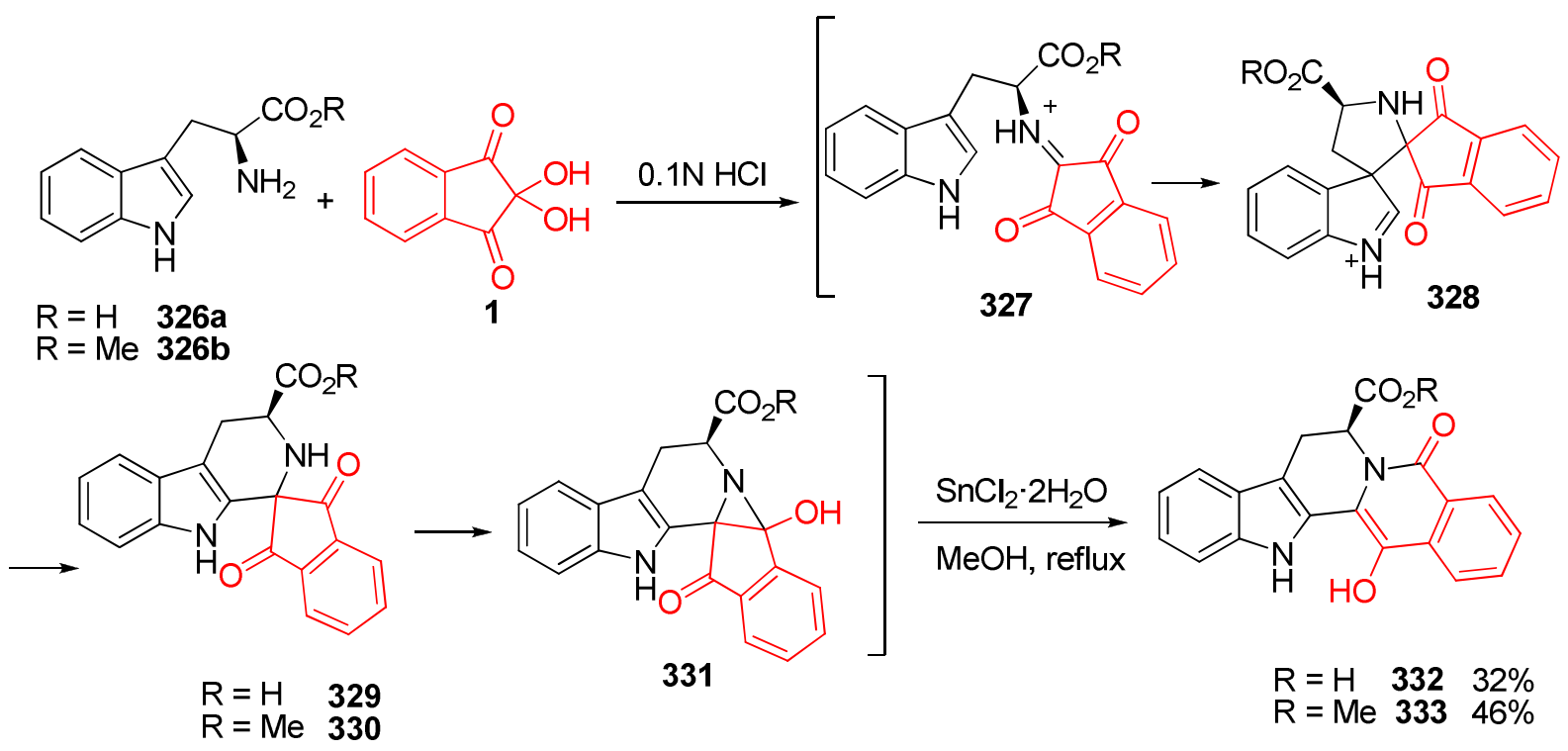

Scheme 107. Mechanism that explains the synthesis of yohimbane skeletons.

In another scenario, Leonard's group showed that yohimbanone 333 experiences oxidative ring cleavage in the presence of cupric acetate to provide a 1,3-disubstituted $\beta$-carboline 334 (Scheme 108). ${ }^{378}$ 
<smiles>CC(=O)[C@H]1Cc2c([nH]c3ccccc23)-c2c(O)c3ccccc3c(=O)n21</smiles>

333

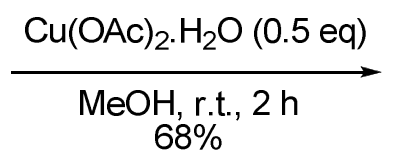

$68 \%$

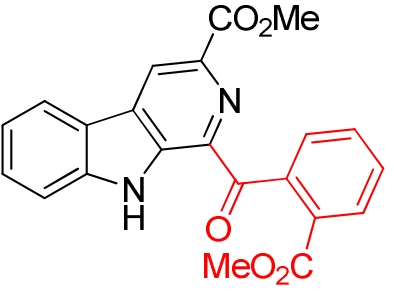

334

Scheme 108. Oxidative rearrangement of yohimbanone.

Similarly, tryptamine 335, or its substituted derivative, was exposed to ninhydrin in refluxing $\mathrm{EtOH} / \mathrm{H}_{2} \mathrm{O}$ to obtain analogues of rutaecarpine 336 (Scheme 109). ${ }^{379}$ Rutaecarpine 337 is one of the major quinazolinocarboline alkaloidal components in Evodiae Fructus, also known as 'Wu-Chu$\mathrm{Yu}$ ', which has been prescribed for treating hypertension in traditional Chinese medicine.

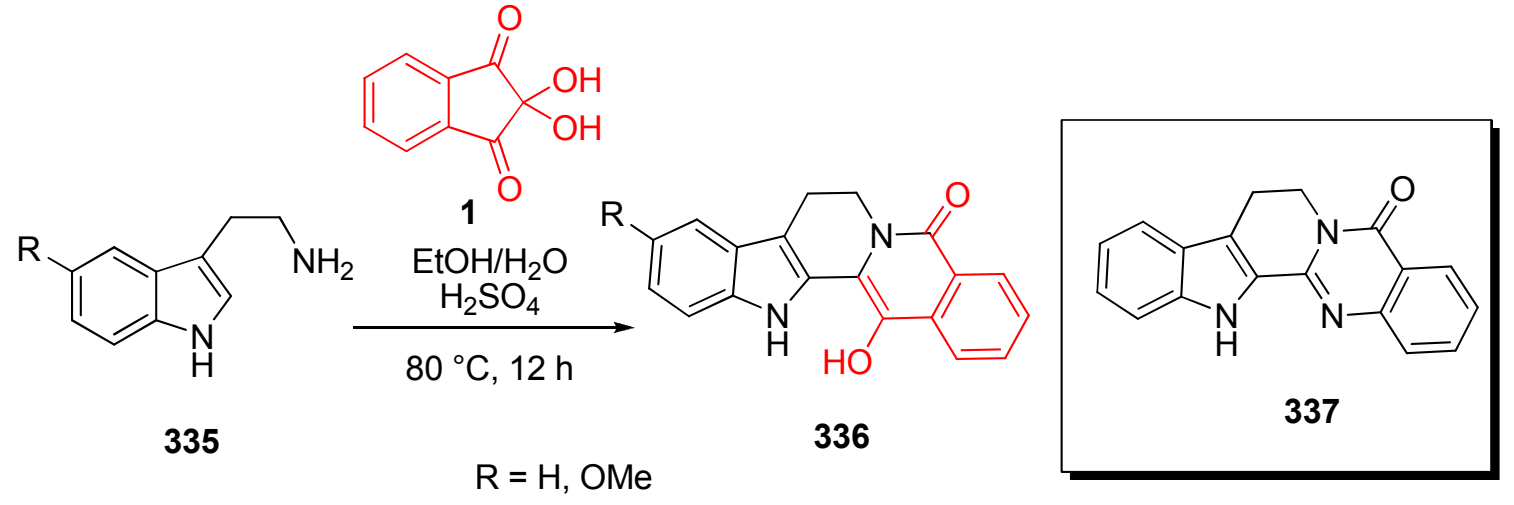

Scheme 109. Reaction of ninhydrin with tryptamine.

Total synthesis of an analog of ochrobirine $\mathbf{3 4 3}$ as an alkaloid possessing a spiro-structure was investigated by Manske and Ahmed (Scheme 110). ${ }^{380}$ Homopiperonylamine 338 was treated with ninhydrin to afford $\mathbf{3 3 9}$ in $86 \%$ yield. The free amine was converted to the $N$-methylamine $\mathbf{3 4 0}$ when refluxed in an aqueous mixture of formic acid and formaldehyde. Sodium borohydride reduction of $\mathbf{3 4 0}$ gave a mixture of $\mathbf{3 4 1}$ and $\mathbf{3 4 2}$ in the ratio 1:2. Several attempts to separate $\mathbf{3 4 2}$ from 341 on thin-layer chromatography over silica or alumina using different solvent systems were unsuccessful. Later, Yu and MacLean used this procedure with 3,4-dimethoxyphenylethylamine and ninhydrin, immersing the flask in an ice-water bath. ${ }^{381}$ 


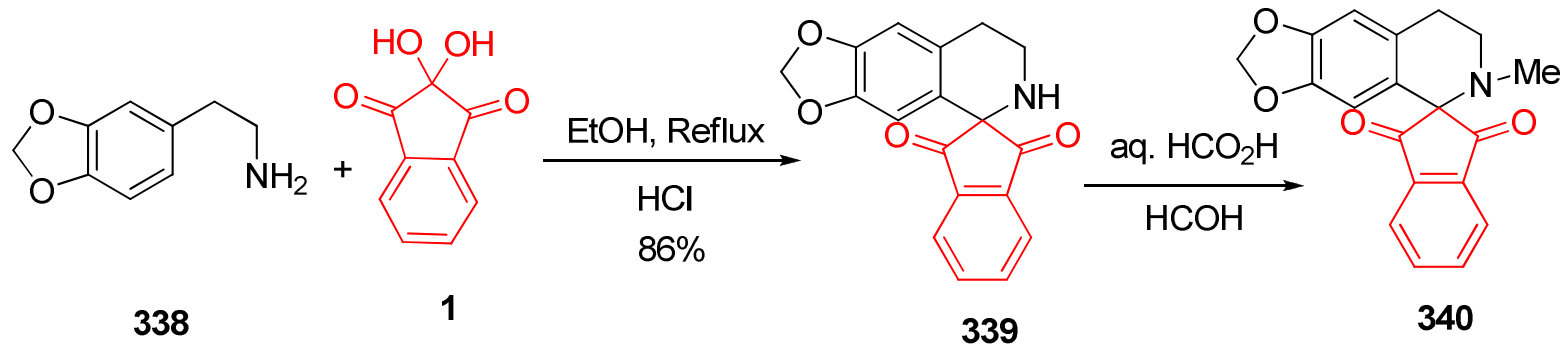

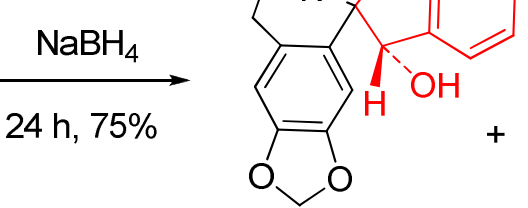

341

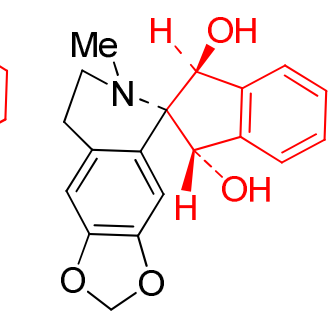

342

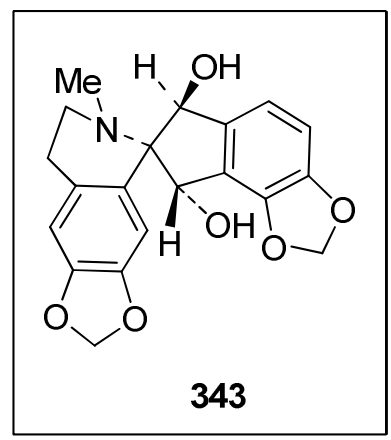

Scheme 110. Mechanism proposed to explain the synthesis of analog of ochrobirine.

4.1.2. Pyrimidines. Pyrimidines are an integral part of DNA and RNA and exhibit diverse pharmacological properties such as antibacterial, ${ }^{382}$ antifungal ${ }^{383}$ and antiviral activities. ${ }^{384}$ Certain pyrimidines and annulated pyrimidine derivatives are also known to display anticancer, ${ }^{385-386}$ antimalarial, ${ }^{387}$ antileishmanial ${ }^{388}$ and antifilarial activities. ${ }^{389}$ Recently, novel ninhydrin-creatinine heterocyclic condensation products 345-347 were synthesized with different solvent systems (Scheme 111). ${ }^{390}$ It was observed that in polar solvents, such as acetic acid or water, the reaction of ninhydrin 1 with creatinine 344 yields the initial condensation product 345 which is then converted into 346. However, when this reaction was carried out in a less polar and aprotic solvent, such as benzene, the addition product $\mathbf{3 4 7}$ was formed.

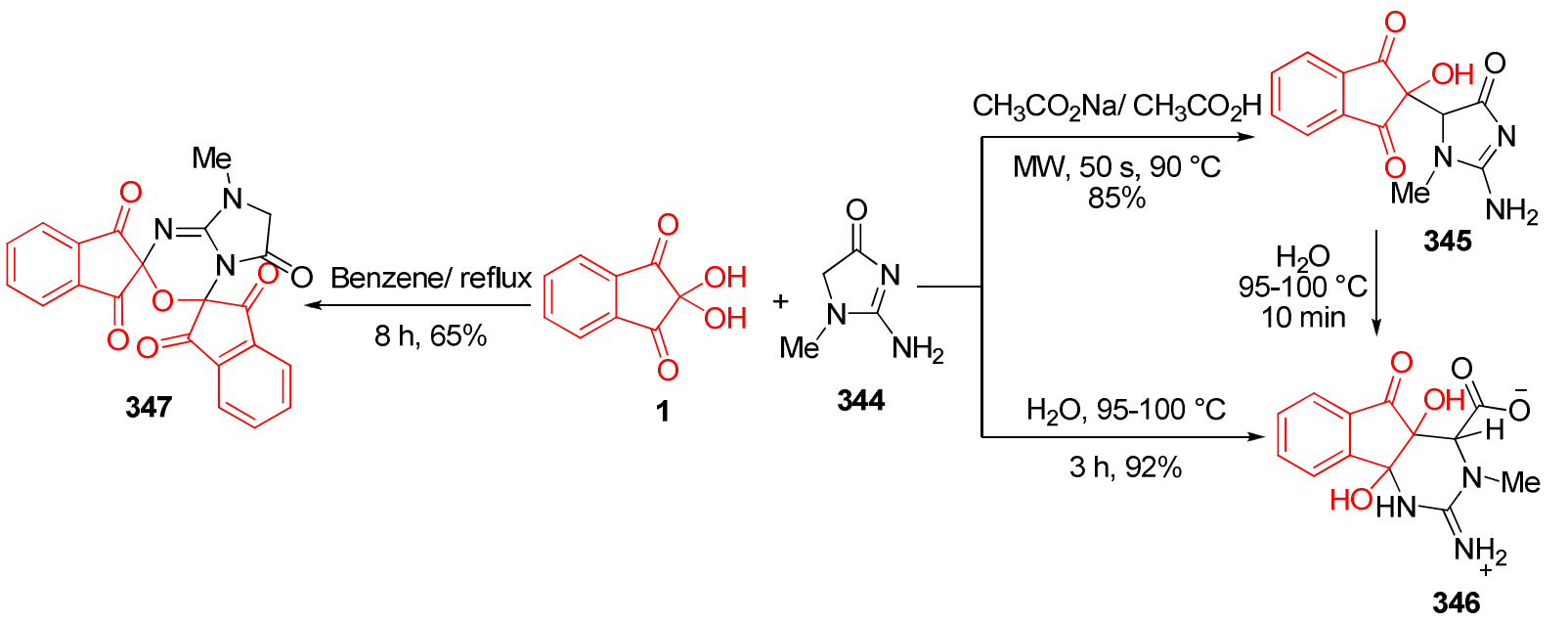

Scheme 111. Synthesis of ninhydrin-creatinine heterocyclic condensation products. 
Spiro pyrimidinone scaffolds $\mathbf{3 4 9}$ were synthesized from the reaction of ninhydrin, barbituric acid 348 and urea or guanidine 347 (Scheme 112). ${ }^{391}$ The scope of the reaction was successfully extended by employing a different 1,3-dione (1,3-indanedione) instead of barbituric acid to afford spiro product $\mathbf{3 5 0}$.

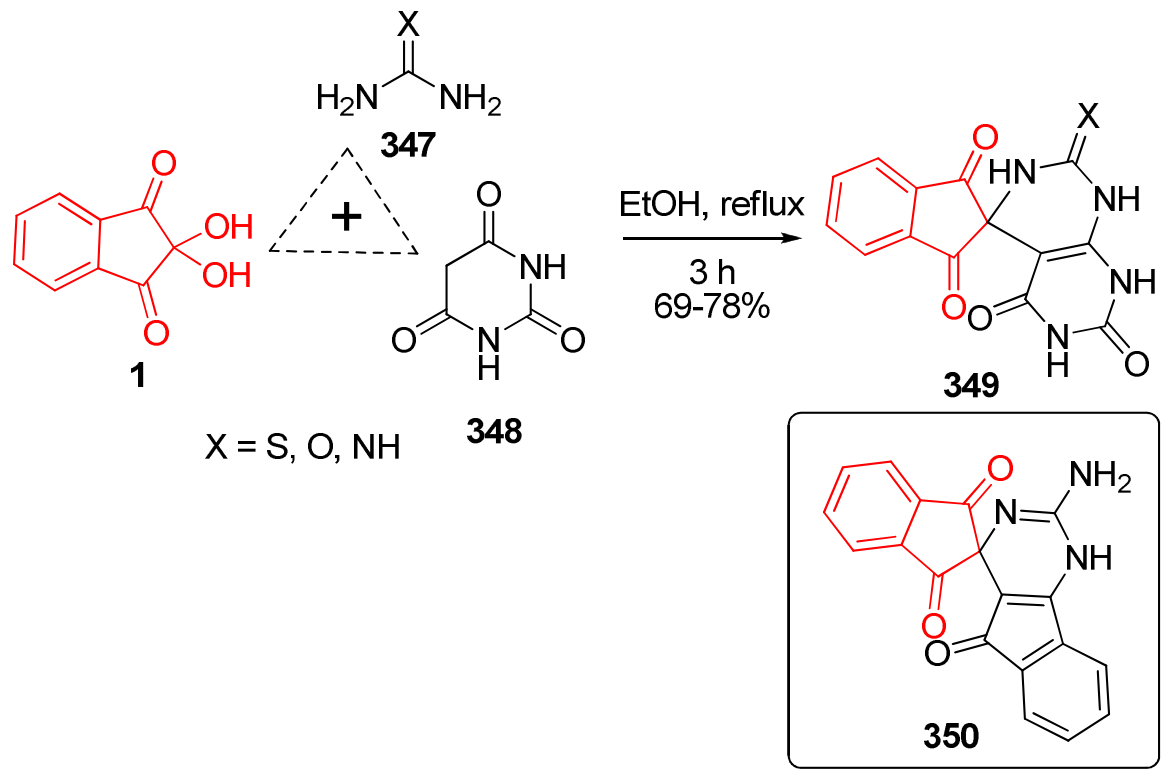

Scheme 112. Three-component synthesis of spiro pyrimidineones from ninhydrin, barbituric acid, and urea or guanidine.

4.1.3. Piperazines and piperazinones. Piperazines are useful synthetic intermediates that are also important structural elements present in a number of investigational and established drugs. ${ }^{392-394}$ Additionally, the piperazinone ring has proven to be a valuable scaffold for the construction of biologically active molecules. ${ }^{395-396}$ In 1978 Schönberg et al. reported the reaction of piperazine 351 with 1, which furnishes the hemiaminal 352 (Scheme 113). ${ }^{266}$<smiles>O=C1c2ccccc2C(=O)C1(O)O</smiles>

1

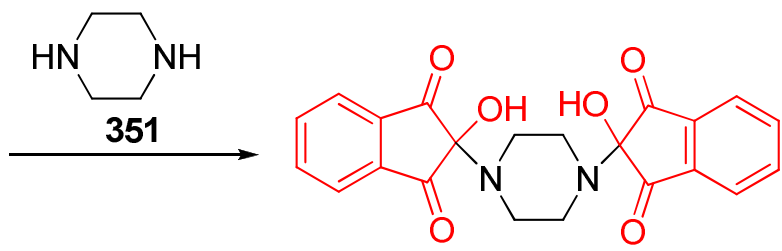

352

Scheme 113. The reaction of piperazine with ninhydrin.

In 1988, preparation of symmetrical bis-ylidene derivatives of piperazine-2,5-dione was achieved by condensation of 1,4-diacetylpiperazine-2,5-dione 353 with ninhydrin to give the bisderivative 354 (Scheme 114). ${ }^{397}$ 
<smiles>CN1CC(=O)N(C)CC1=O</smiles>

353<smiles>O=C1c2ccccc2C(=O)C1(O)O</smiles>

1<smiles>CCOCCN(C)C(C)C</smiles>

$35454 \%$

Scheme 114. Condensation of 1,4-diacetylpiperazine-2,5-dione with ninhydrin.

4.1.4. Pyrazines. Pyrazine has been paid great attention, because the diazine rings form an important class of compounds presented in several natural and synthetic compounds. ${ }^{398-399}$ Pyrazine derivatives have been widely used in the fields of medicinal chemistry for the skeleton of biologically active sites. ${ }^{400-401}$ Condensation of ninhydrin and ortho-diamino-containing oligothiophene 355 was investigated as a model compound to design the incorporation of orthodiamino-containing oligothiophene into the fullerene $\pi$-system to synthesize highly light-absorbing fullerene materials 357 (Scheme 115). ${ }^{402}$

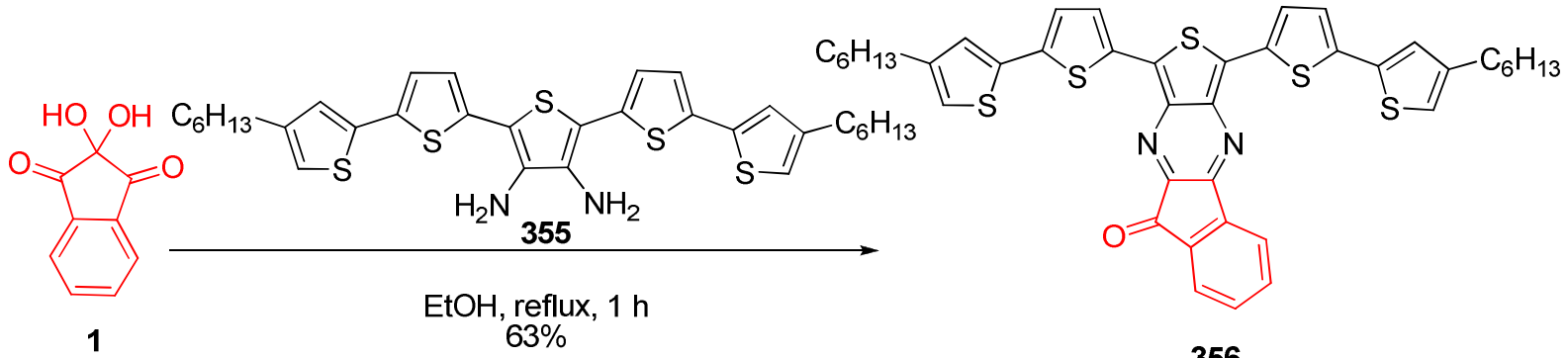

1 $63 \%$

356

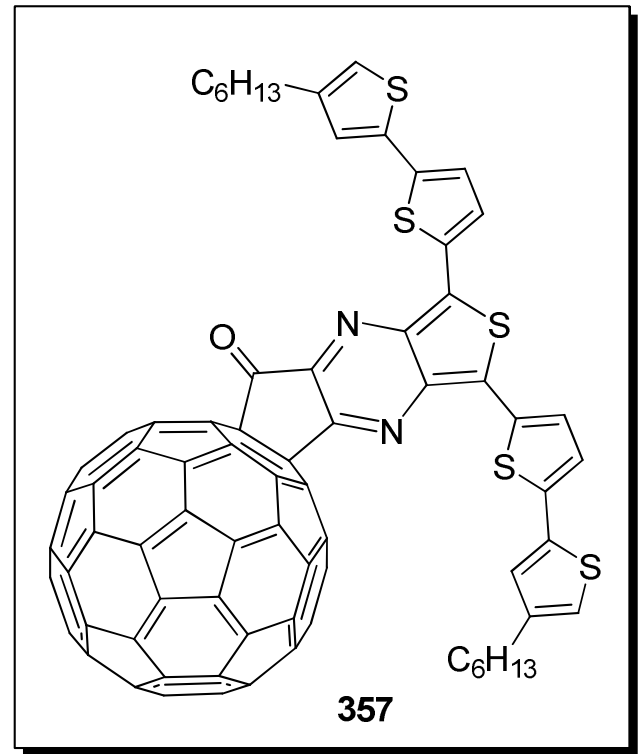

Scheme 115. Condensation of ninhydrin with ortho-diamino-containing oligothiophene. 
The reaction of 1,2-bishydroxylamines 358 with ninhydrin 1 to synthesize functional derivatives of condensed dihydroindeno[1,2- $b$ ]pyrazine $N, N$ '-dioxides 360 was investigated by Volodarsky and co-workers (Scheme 116) ${ }^{403}$ In a related study, the same group found that the reaction of 1,2bis(methoxyamino)cycloalkanes 359 with ninhydrin affords the stable $N, N^{\prime}$-dimethoxypiperazine 361 as a racemic mixture. ${ }^{404}$

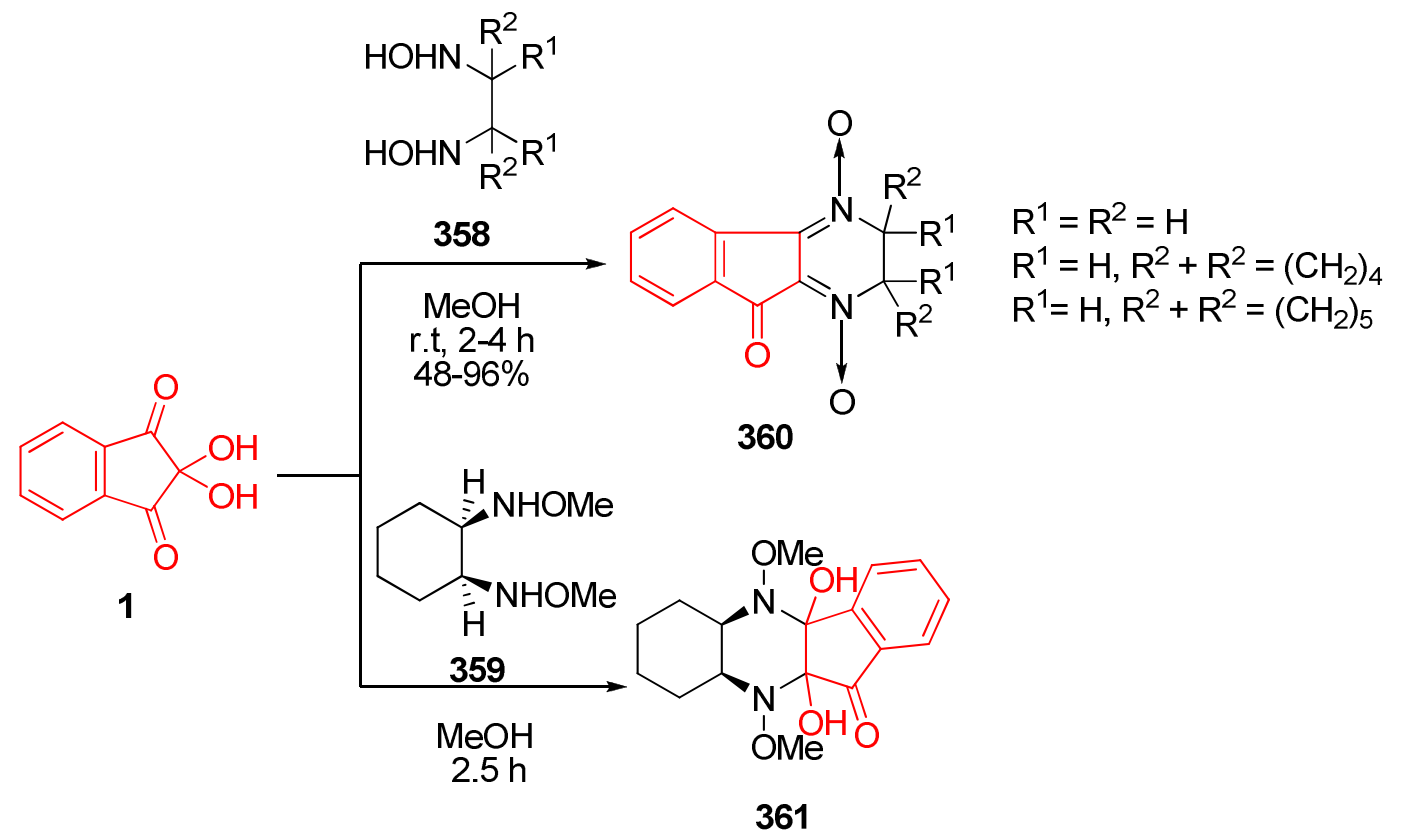

Scheme 116. The reaction of 1,2-bishydroxylamines with ninhydrin.

Several new benzimidazole based polycyclic compounds of potential pharmaceutical interest were prepared, starting from 2-cyanomethylbenzimidazole 362 and ninhydrin 1. 2-Cyano-2-(1,3dioxo-2-indenylidene) benzimidazole 363 was then treated with bidentate reagents such as hydrazines and 5-amino-1H-3-methylsulfanylpyrazole-4-carbonitrile 367. The two hydrogen atoms of pyrazole and imidazole rings of $\mathbf{3 6 4}$ were released when reacted with each of $\alpha$-bromo compounds 365, yielding pyrazine derivatives 366 (Scheme 117). ${ }^{405}$ Reaction of 5-amino-1H-3methylsulfanylpyrazole-4-carbonitrile 367 with compound 363 along with annulation of the pyrimidine ring afforded pyrazole derivatives indenopyrimidopyrazole 368 which was simply converted to the corresponding new polycyclic pyrazole derivative $\mathbf{3 6 9}$. 


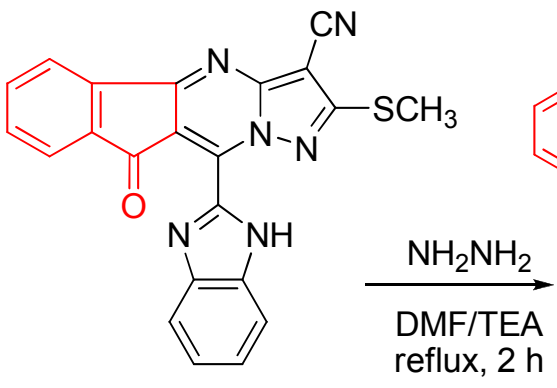

368<smiles>Nc1n[nH]c2nn3c(-c4nc5ccccc5[nH]4)c4c(nc3c12)-c1ccccc1C4=O</smiles>

369

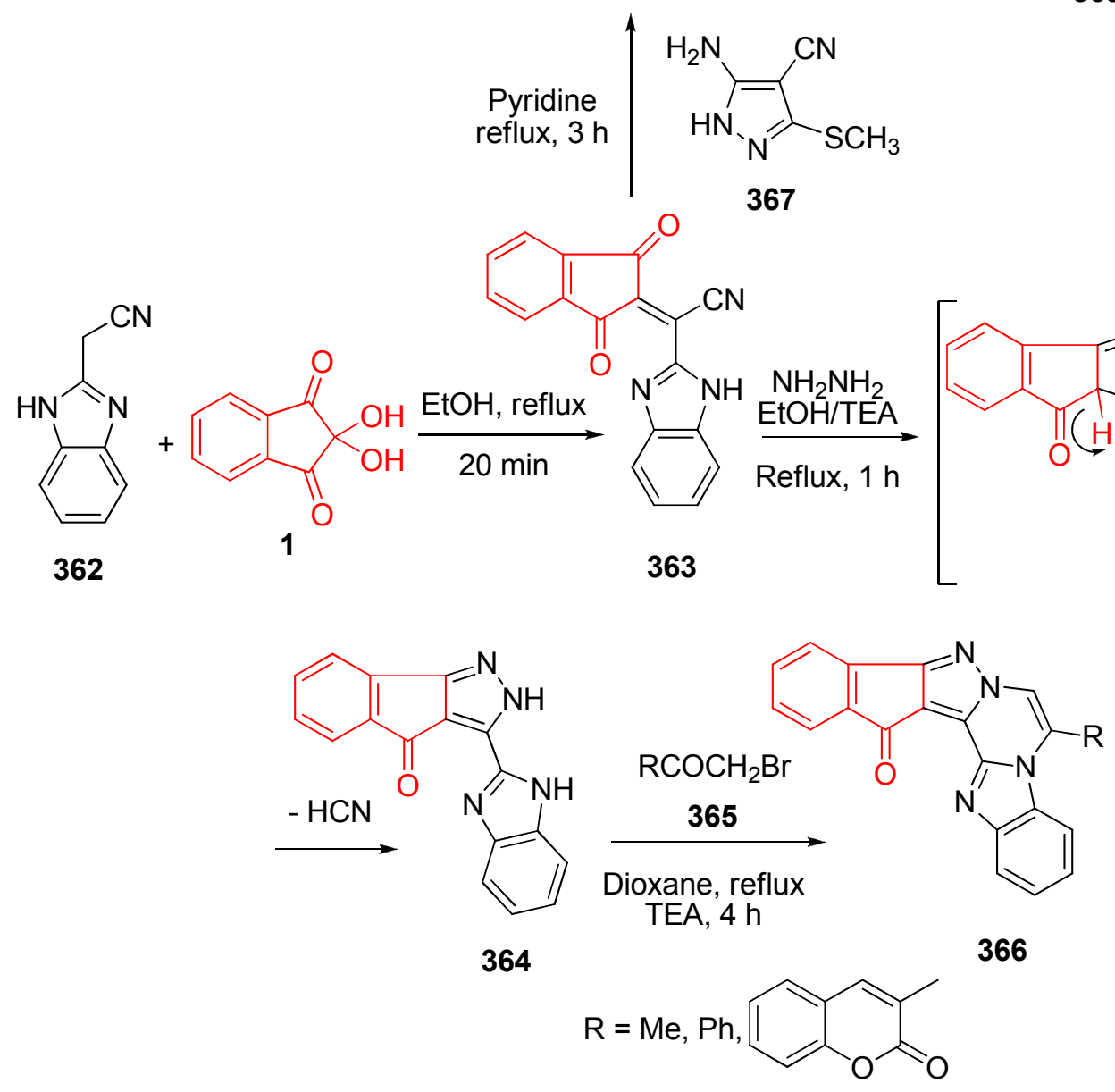

Scheme 117. Synthesis of pyrazine derivatives from ninhydrin and 2-cyanomethylbenzimidazole.

Schiff's base derived from the condensation of ninhydrin with diaminomaleonitrile $\mathbf{3 7 0}$ as a colorimetric probe for the selective determination of $\mathrm{Hg}^{2+}$ and $\mathrm{CH}_{3} \mathrm{COO}^{-} / \mathrm{F}^{-}$in ethanol-water as well as in aqueous solution, was also investigated (Scheme 118). ${ }^{406}$ This is the first report of a colorimetric sensor derived from ninhydrin for the detection of ionic analytes. 


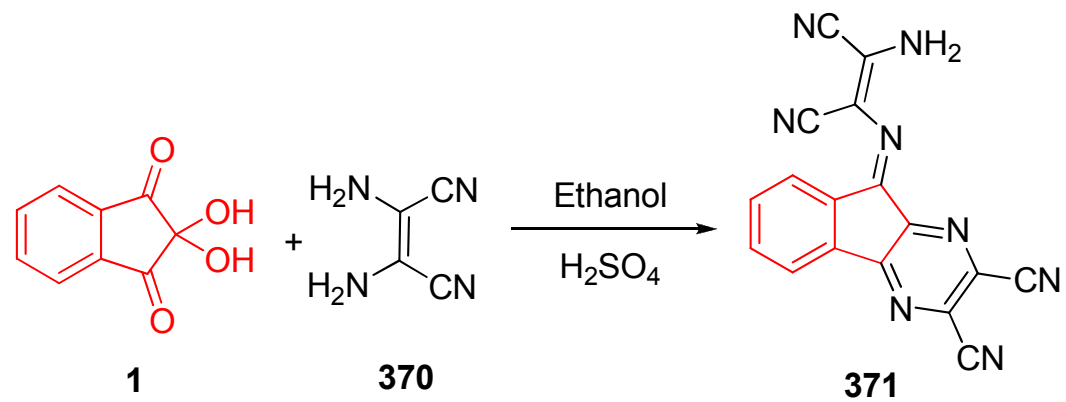

Scheme 118. Condensation of ninhydrin with diaminomaleonitrile.

A multicomponent domino Knoevenagel condensation/ 1,3-dipolar cycloaddition reaction of ninhydrin 1, malononitrile and sodium azide in water without assistance of any catalyst was reported by Bazgir and co-workers (Scheme 119). ${ }^{407}$ Similarly, they used diaminomaleonitrile 370 instead of malononitrile in this reaction to obtain the corresponding product $\mathbf{3 7 3}$ in $89 \%$ yield (Scheme 120). ${ }^{408}$<smiles>O=C1c2ccccc2C(=O)C1(O)O</smiles>

1<smiles>N#C[C+]C#N</smiles>

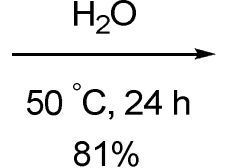
$81 \%$<smiles>N#CC(=C1C(=O)c2ccccc2C1=O)c1nnn[nH]1</smiles>

372

Scheme 119. Three-component reaction of ninhydrin, malononitrile, and sodium azide.

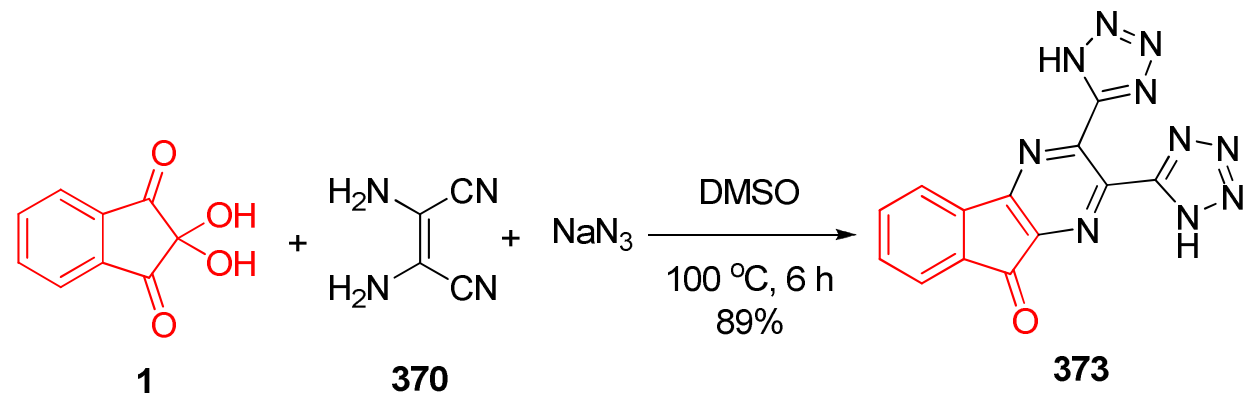

Scheme 120. Three-component reaction of ninhydrin, diaminomaleonitrile, and sodium azide.

4.1.5. Quinoxalines. Quinoxaline derivatives are of significant interest as they are noteworthy intermediates for the manufacturing of pharmaceuticals ${ }^{409}$ and advanced materials. ${ }^{410-411}$ Quinoxalines are very important compounds due to their wide spectrum of biological activities such as anticancer, ${ }^{412-413}$ antibacterial ${ }^{414}$ and activity as kinase inhibitors. ${ }^{415}$ It was reported that the 
reaction of 2,3-diamino-1,4-naphthoquinone 374 with ninhydrin in warm aqueous acetic acid yields $11 H$-benzo $[g]$ indeno[1,2- $b$ ] quinoxaline- 6,11,13-trione 375 in 90\% yield (Scheme 121). ${ }^{416}$<smiles>NC1C(=O)c2ccccc2C(=O)C1N</smiles>

374<smiles>O=C1c2ccccc2C(=O)C1(O)O</smiles>

1 aq $\mathrm{AcOH}, 40-60^{\circ} \mathrm{C}$

10 h, $90 \%$<smiles>O=c1c2ccccc2c(=O)c2nc3c(nc12)c(=O)c1ccccc13</smiles>

375

Scheme 121. The reaction of 2,3-diamino-1,4-naphthoquinone with ninhydrin.

A solid-state cascade reaction of ninhydrin with $o$-phenylenediamines $\mathbf{1 1 7}^{2,417-418}$ was studied by Kaupp and co-workers (Scheme 122). ${ }^{419}$ The yields were quantitative and the solid state reaction gave pure crystalline products just by milling stoichiometric mixtures of the crystalline reagents. 1,2-Diamines reacted with ninhydrin to form indenoquinoxaline ketones 126. Bismuth(III) triflate 120 $^{420}$ and polyaniline-sulfate salt ${ }^{421}$ were also used as catalytic systems in these reactions. Two patents used 9-oxo-9H-indeno[1,2-b]pyrazine-2,3-dicarbonitrile $\mathbf{3 7 9}$ to synthesize cyano-pyrazine derivatives, and used it as a medicament to inhibit one or more cysteine proteases, ${ }^{422}$ as well as a material for an organic electroluminescence device. ${ }^{423}$<smiles>O=C1c2ccccc2C(=O)C1(O)O</smiles>

1
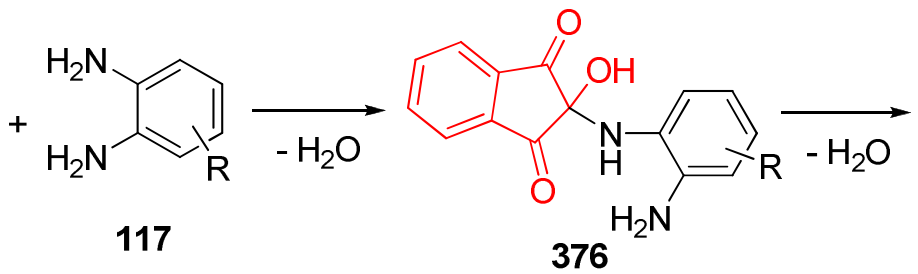

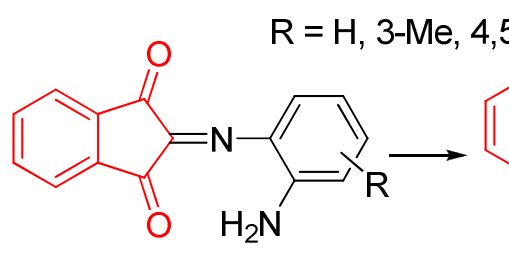

377<smiles>[R]c1ccc2c(c1)N=C1C(=O)c3ccccc3C1(O)N2</smiles>
378<smiles>[R]c1ccc2nc3c(nc2c1)C(=O)c1ccccc1-3</smiles>

126<smiles>Cc1cc2nc3c(nc2cc1C#N)-c1ccccc1C3=O</smiles>

$\mathrm{R}=\mathrm{H}, 6-\mathrm{Me}, 7,8-\mathrm{Me}_{2}$

Scheme 122. Mechanism proposed to explain the synthesis of indenoquinoxaline ketones. 
The condensation of ortho-aminophenols and $N$-benzylsulfonyl-o-phenylenediamine $\mathbf{3 8 0}$ with ninhydrin 1 affords tetracyclic products 381, proceeding via a condensation reaction between the amino and the carbonyl group at position 1 of ninhydrin (Scheme 123). ${ }^{44-425}$

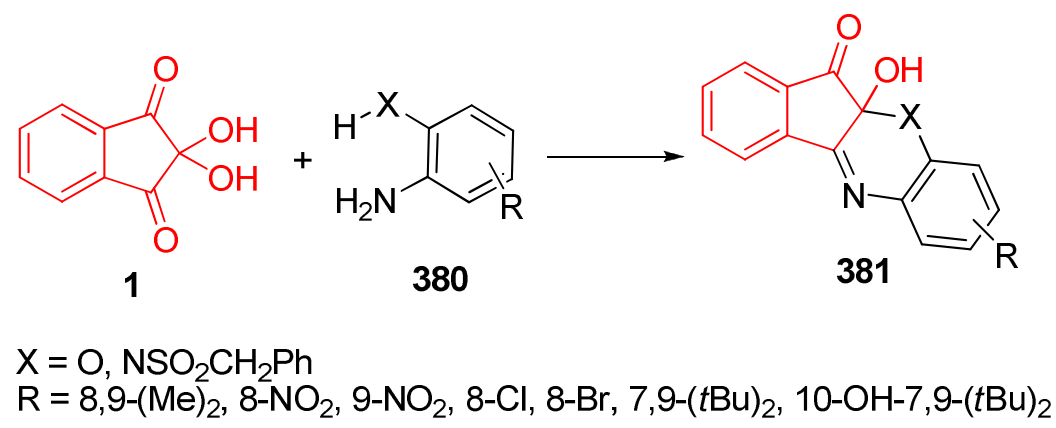

Scheme 123. The condensation of ortho-aminophenols and $N$-benzylsulfonyl-o-phenylenediamine with ninhydrin.

1,2,4,5-Benzenetetramine tetrahydrochloride $\mathbf{3 8 2}$ was used in the reaction with ninhydrin to give the corresponding products $\mathbf{3 8 3 - 3 8 6}$ (Scheme 124). ${ }^{426}$ These derivatives were investigated as a material for an organic electroluminescence device.<smiles>O=C1c2ccccc2C(=O)C1(O)O</smiles>

1<smiles></smiles>

382<smiles>CC(C)(C)c1cc2nc3c(nc2c[nH+]1)C(=O)c1ccccc1-3</smiles>

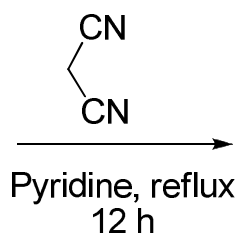<smiles>N#CC(C#N)=C1c2ccccc2-c2nc3cc4nc5c(nc4cc3nc21)-c1ccccc1-5</smiles>

385<smiles>N#CC(C#N)=C1c2ccccc2-c2nc3cc4nc5c(nc4cc3nc21)-c1ccccc1-5</smiles>

386

Scheme 124. Reaction of 1,2,4,5-benzenetetramine tetrahydrochloride with ninhydrin.

Condensation of ninhydrin with the precursor diamine compounds (2,3-diaminophenazines) 387 in dilute acetic acid results in the formation of indeno-pyrazino-dipyrido-phenazines $\mathbf{3 8 8}$ (Scheme 
125). ${ }^{427-429}$ Thereafter, complexes 389 and $\mathbf{3 9 0}$ were obtained by direct reaction of the ligand with the appropriate mole ratios of the precursor complexes in ethylene glycol.

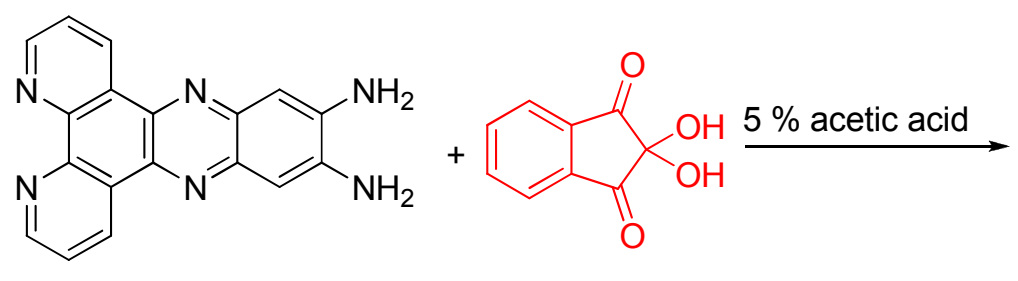

387

1<smiles></smiles>

388

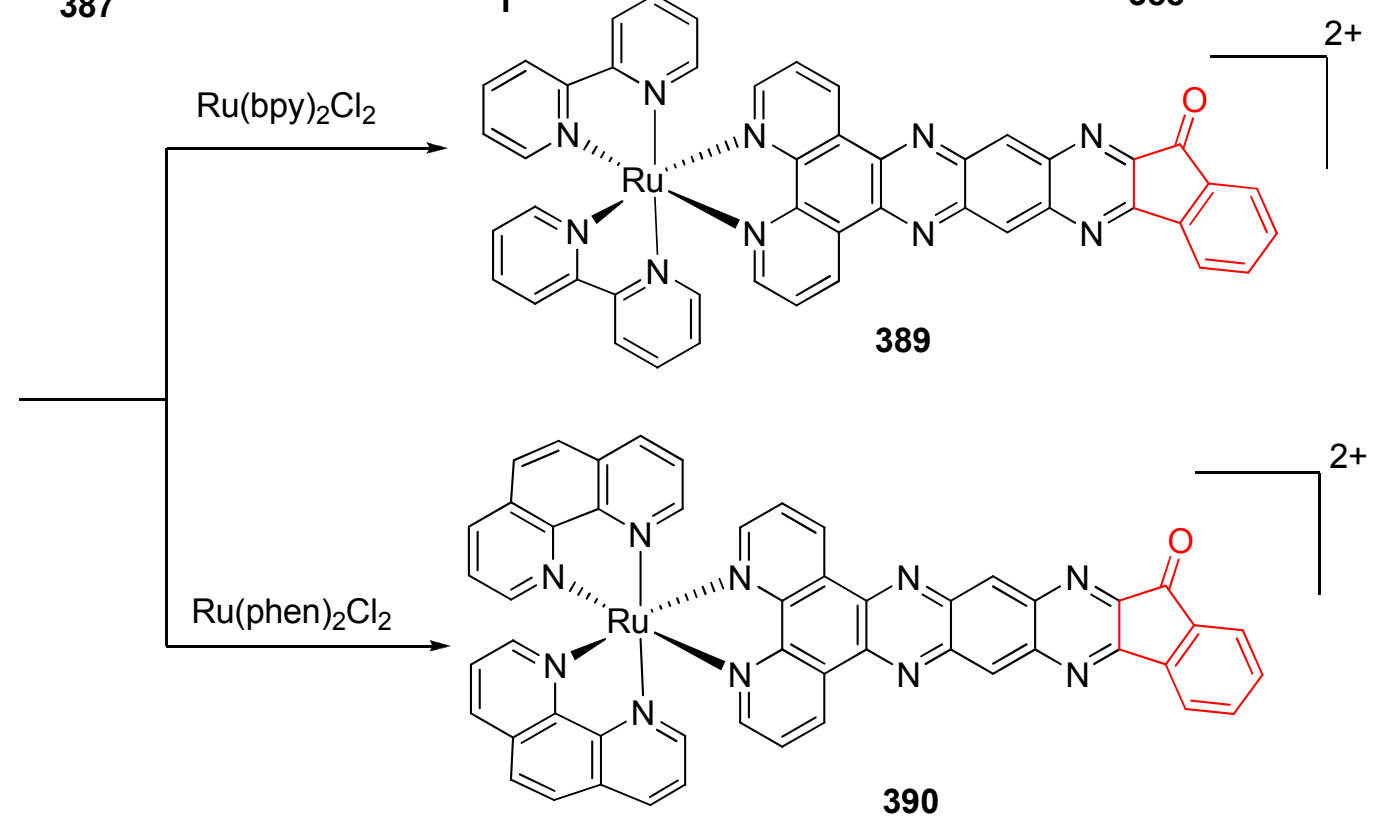

Scheme 125. Condensation of ninhydrin with the precursor diamine compounds $(2,3-$ diaminophenazines).

Azizian and co-workers used (alkoxycarbonylmethyl)triphenylphosphonium bromides in the three-component synthesis of alkyl indeno[1,2- $b$ ]quinoxalin-11-ylideneacetates 391 in water ${ }^{430}$ and under solvent free conditions (Scheme 126). ${ }^{431}$ It is well known that quinoxaline $\mathbf{1 2 6}$ is formed from the condensation of ninhydrin 1 with 1,2-phenylenediamine 117, and a subsequent Wittig reaction of the ylide with quinoxaline $\mathbf{1 2 6}$ produces new adducts 391 .

The same authors also described the synthesis of racemic 11-(1H-pyrrol-1-yl)-11H-indeno[1,2b] quinoxaline derivatives $\mathbf{3 9 2}^{432}$ and 2-(indenoquinoxalin- 11-ylidene) malononitrile derivatives $\mathbf{3 9 3}^{433}$ via the three-component condensation of ninhydrin $\mathbf{1}$ and 1,2-phenylenediamines 117 with 4hydroxyproline or malononitrile, respectively (Scheme 127). 


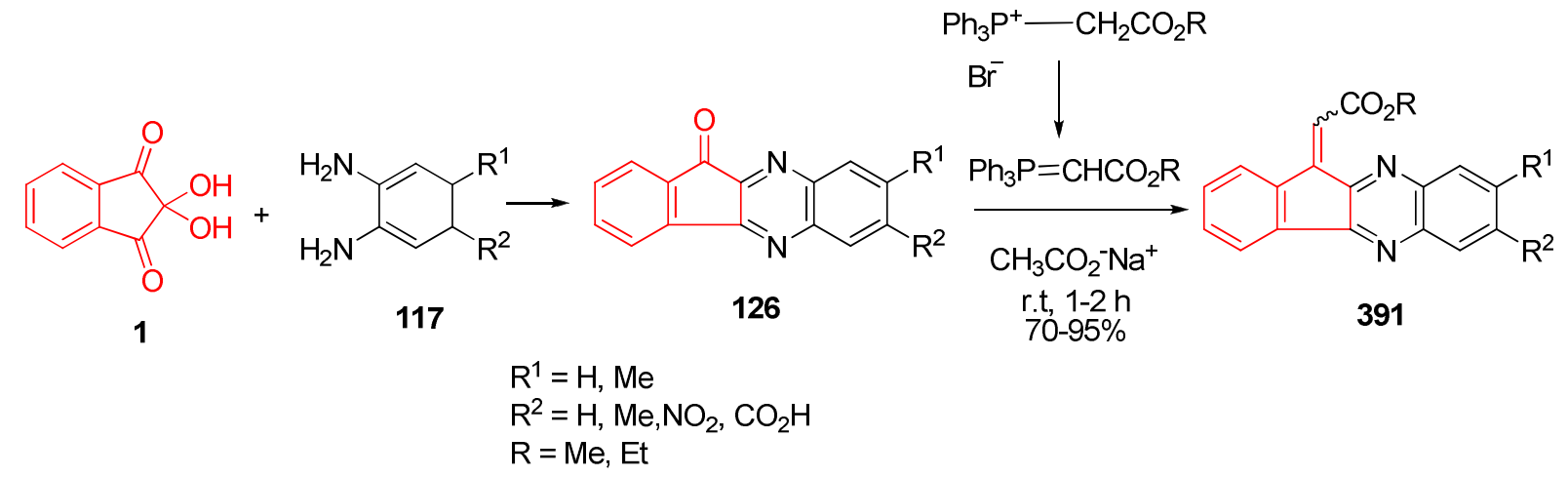

Scheme 126. Mechanistic explanation of three-component synthesis of alkyl indeno[1,2$b$ ]quinoxalin-11-ylideneacetates.

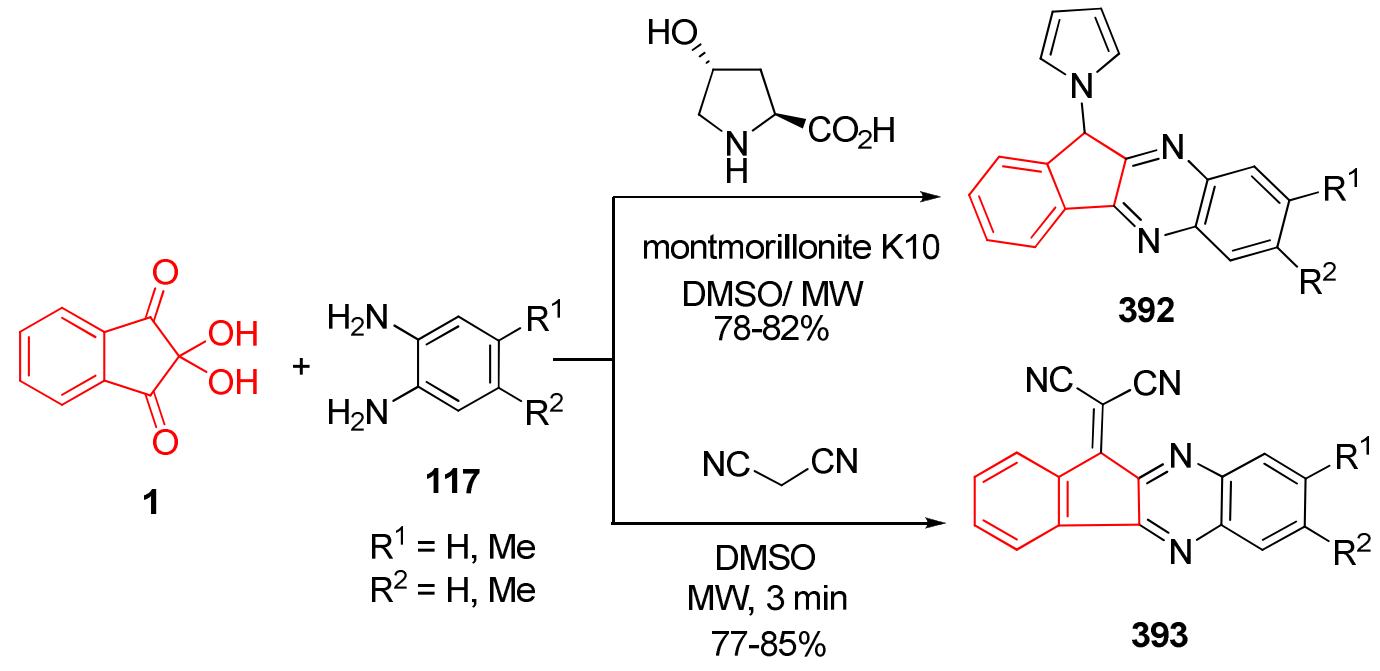

Scheme 127. Three-component condensation of ninhydrin and 1,2-phenylenediamines with 4hydroxyproline or malononitrile.

The receptors 396a-b were synthesized in three steps by means of a simple Schiff base condensation reaction. In first step, a quinoxaline derivative of ninhydrin (compound 126) was prepared using a Schiff base condensation reaction between ninhydrin and 1,2-phenylenediamine 117, as depicted in Scheme 128. Compound 395 is then synthesized via a Schiff base condensation reaction between either 2-hydroxybenzaldehyde (for receptor 396a) or 2-hydroxy-5nitrobenzaldehyde (for receptor 396b), and hydrazine hydrate. ${ }^{434}$ The receptors exhibit high sensitivity and selectivity towards $\mathrm{Cu}^{2+}$ in aqueous medium. 


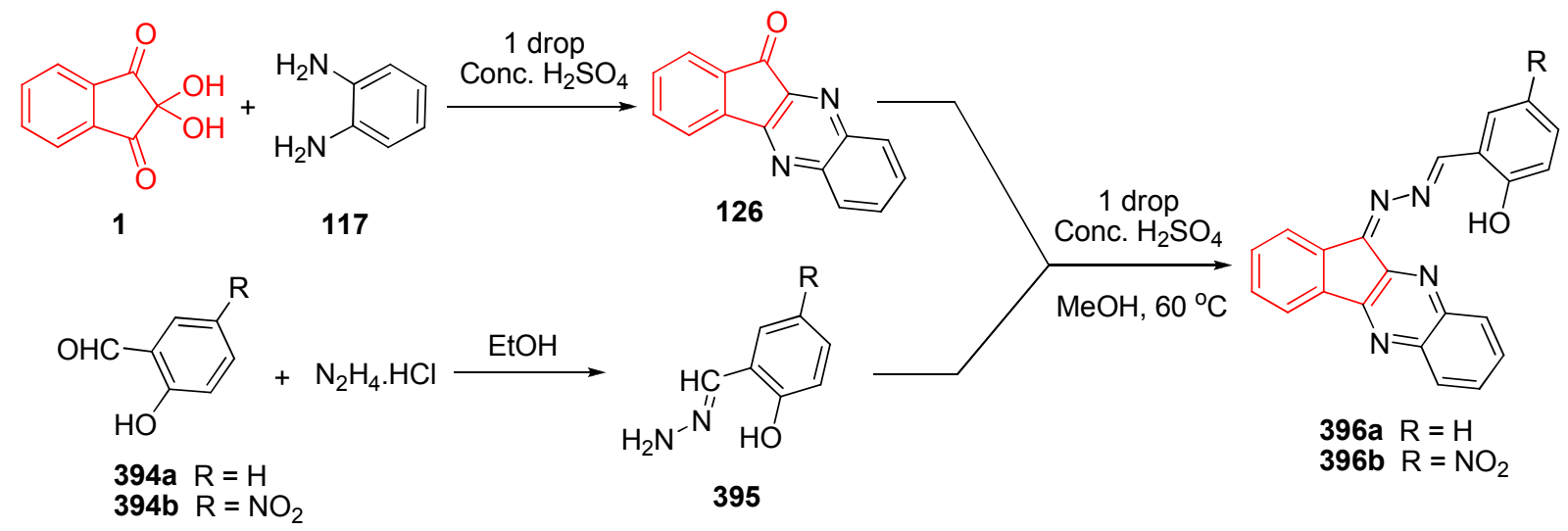

Scheme 128. Mechanism that accounts for the formation of the corresponding receptors.

The reaction of ninhydrin with 1,2-phenylenediamine and indole derivatives was reported to furnish meso bisindolylindeno[1,2-b] quinoxalines 397 in the presence of montmorillonite K-10 catalyst (Scheme 129). ${ }^{435}$

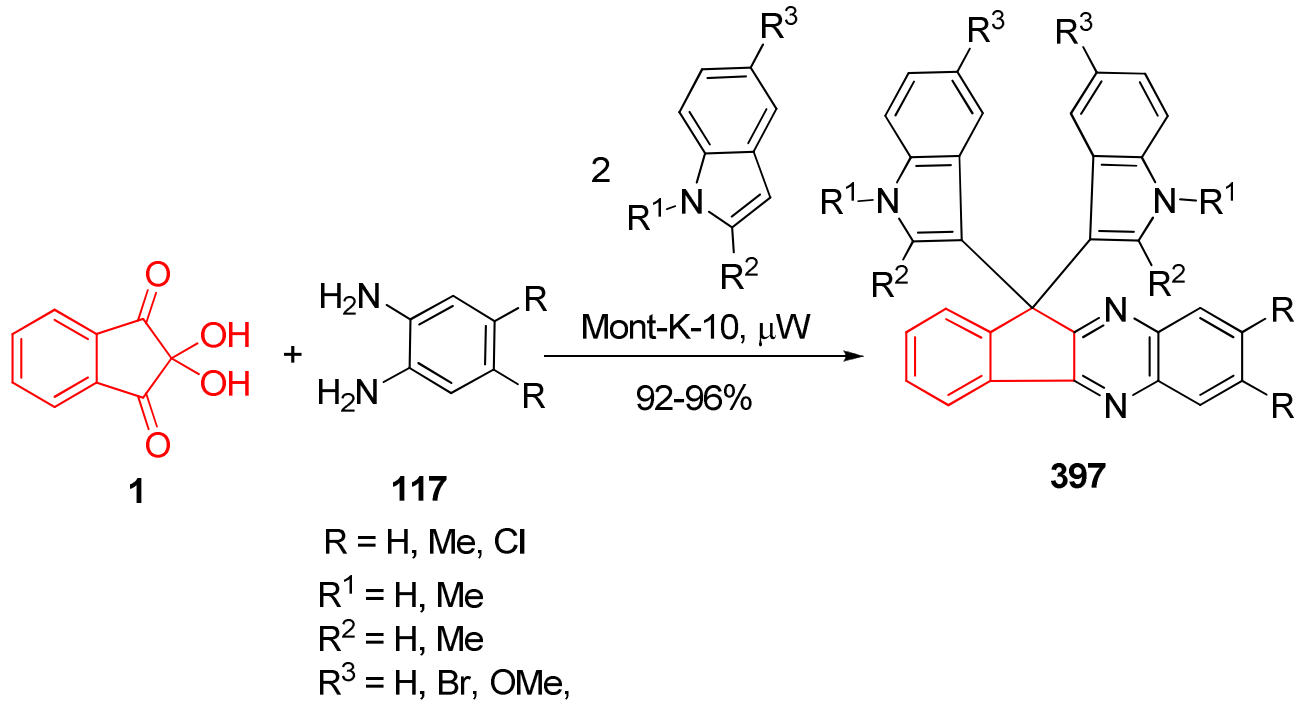

Scheme 129. Synthesis of bisindolylindeno[1,2-b]quinoxalines from ninhydrin, ,2phenylenediamine, and indole derivatives.

1,2-Phenylenediamine 117 was reacted with ninhydrin $\mathbf{1}$ and acetic anhydride to afford biindeno[1,2-b]quinoxaline 399 (Scheme 130). ${ }^{436}$ This compound was screened for its anticancer, antimicrobial, and cholinesterase enzymes inhibitory activities. It exhibited good anticancer and antibacterial and anticandida activities comparable to that of clinically used antifungal agent, amphotericin B. Compound 399 was also found to have highly selective inhibitory activity against acetylcholinesterase with moderate inhibitory activity against butyrylcholinesterase. 


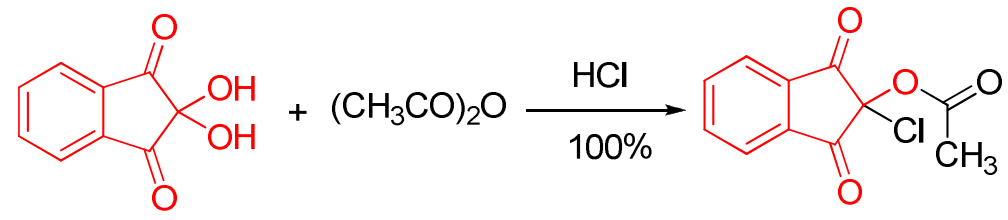

1 398

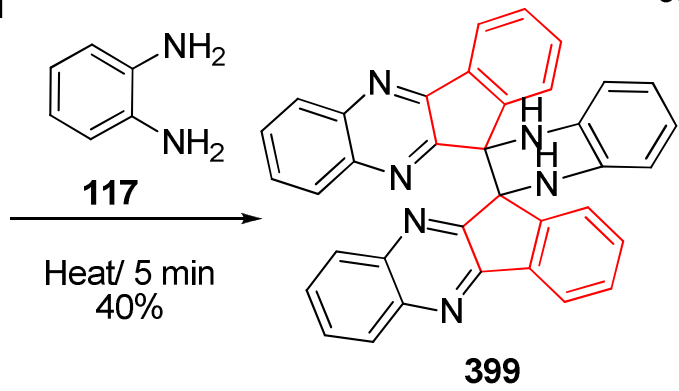

Scheme 130. Synthesis of biindeno[1,2-b]quinoxaline from ninhydrin, acetic anhydride, and 1,2phenylenediamine.

4.1.6. Phthalazinones. Phthalazinones are an important class of heterocycles with diverse biological activities like vasorelaxant activity, ${ }^{437}$ phosphodiesterase inhibitors, ${ }^{438}$ inhibitor of Poly(ADP-ribose), ${ }^{439}$ or protein kinase inhibitors. ${ }^{440}$ The synthesis of biologically important phthalazinones was reported by Pramanik and co-workers. Starting from ninhydrin, acid catalyzed condensation produces the adduct 401, which is subsequently refluxed with para substituted phenols 204 in acetic acid. This second condensation produces the meso adduct $\mathbf{4 0 2}$ in very good yields; the adducts that form prefer the cyclic hemiketal form 403. Finally, when adducts $\mathbf{4 0 3}$ are stirred in hydrazine hydrate at room temperature for 22-30 h, the products 404 (racemic) are formed and display significant antibacterial activities (Scheme 131). ${ }^{441}$

A convenient method for preparing 4-diarylmethyl-1-(2H)-phthalazinones 405 and 407 was reported, starting from easily prepared 2,2-diaryl-1,3-indanediones such as $\mathbf{2 7 5}$ and $\mathbf{4 0 6}$. It was found that 2,2-diaryl-1,3-indanediones react with hydrazine hydrate (99\%) under refluxing conditions to give 4-diarylmethyl-1-(2H)phthalazinones $\mathbf{4 0 5}$ and $\mathbf{4 0 7}$ in very high yields (Scheme 132). ${ }^{442-443}$ Other report also shows the possibility of using 2-hydroxy-2,2'-biindan-1,1',3,3'-tetrone 254 in this reaction which results in the formation of 1-aryl-1,2-di[3,4-dihydro-4-oxophthalazin-1-yl] ethanes $\mathbf{4 0 8}$. $^{44}$ 
<smiles>O=C1c2ccccc2C(=O)C1(O)O</smiles>

1<smiles>[R]c1c([R])c([R])c2c(c1[R])OC1(O)c3ccccc3C(=O)C21c1c(C)n[nH]c1O</smiles>

403<smiles>CCCCC(C)(Cl)Cl</smiles>

400

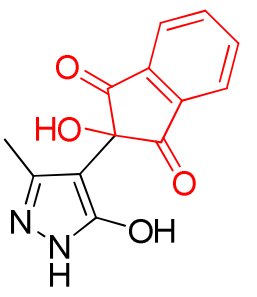

401

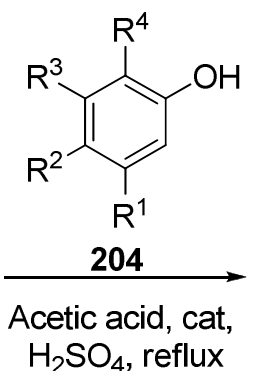

$\mathrm{H}_{2} \mathrm{SO}_{4}$, reflux<smiles>[R]c1c([R])c(O)c(C2(c3c(C)n[nH]c3O)C(=O)c3ccccc3C2=O)c(O)c1[R4]</smiles>

402

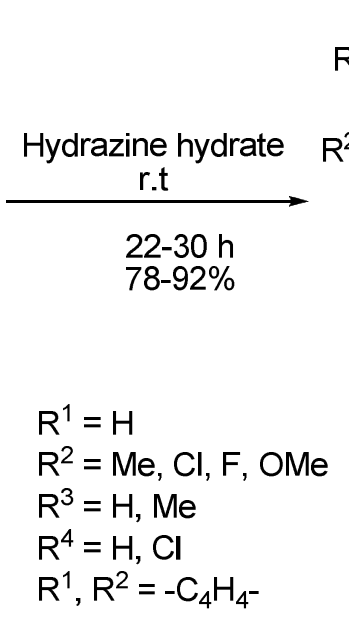<smiles>[R]c1c([R])c([R])c(C(c2c(C)n[nH]c2O)c2n[nH]c(=O)c3ccccc23)c(O)c1[R]</smiles>

404

Scheme 131. Mechanistic explanation of the synthesis of phthalazinone derivatives.<smiles>[3H][Hg]C1(O)C(=O)c2ccccc2C1=O</smiles><smiles>O=C1c2ccccc2C(=O)C1(Br)Br</smiles>

406<smiles>O=C1c2ccccc2C(=O)C1(Br)Br</smiles>

275<smiles>N[R10](=O)c1ccc2c(C(Br)Br)n[nH]c(=O)c2c1</smiles>

405

$\mathrm{Ar}=\mathrm{Ph}, p-\mathrm{MeC}_{6} \mathrm{H}_{4}, p-\mathrm{BrC}_{6} \mathrm{H}_{4}, p-\mathrm{IC}_{6} \mathrm{H}_{4}$, $p-\mathrm{ClC}_{6} \mathrm{H}_{4}, p-\mathrm{MeOC}_{6} \mathrm{H}_{4}, 2,4-(\mathrm{MeO})_{2} \mathrm{C}_{6} \mathrm{H}_{3}$

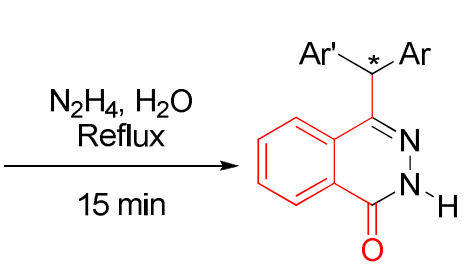

407

408

$\mathrm{Ar}=2,3,4-(\mathrm{MeO})_{3} \mathrm{C}_{6} \mathrm{H}_{2}, 2,4-(\mathrm{MeO})_{2} \mathrm{C}_{6} \mathrm{H}_{3}$ $\mathrm{Ar}^{\prime}=p-\mathrm{MeOC}_{6} \mathrm{H}_{4}, p-\mathrm{ClC}_{6} \mathrm{H}_{4}$

Scheme 132. Synthesis of 4-diarylmethyl-1-(2H)-phthalazinones from ninhydrin.

4.1.7. Tetrahydroquinolines. Tetrahydroquinoline moiety is an important structural feature of various natural products and pharmaceutical agents that have exhibited a broad range of biological 
activities. $^{445-448}$ Substituted tetrahydroquinolines are the core structures in many important pharmacological agents and drug molecules such as antitubercular agents ${ }^{449}$ and anticancer drugs. ${ }^{450}$ Spiro $1 H$-indeno[1,2- $b]$ benzo[f]quinoline $\mathbf{4 1 0}$ was isolated via a one-pot three-component reaction of ninhydrin 1, 1,3-indanedione 14, and naphthalene-2-amine $\mathbf{4 0 9}$ in aqueous medium, with the aid of $p$-toluenesulfonic acid ( $p$-TSA) as the catalyst (Scheme 133). ${ }^{451}$ Later, this reaction was carried out by the same group in ionic liquid $N, N, N, N$-tetramethylguanidinium triflate $\left(\mathrm{TMGT}_{\mathrm{f}}\right){ }^{452}$ The ionic liquid served both as solvent and catalyst.

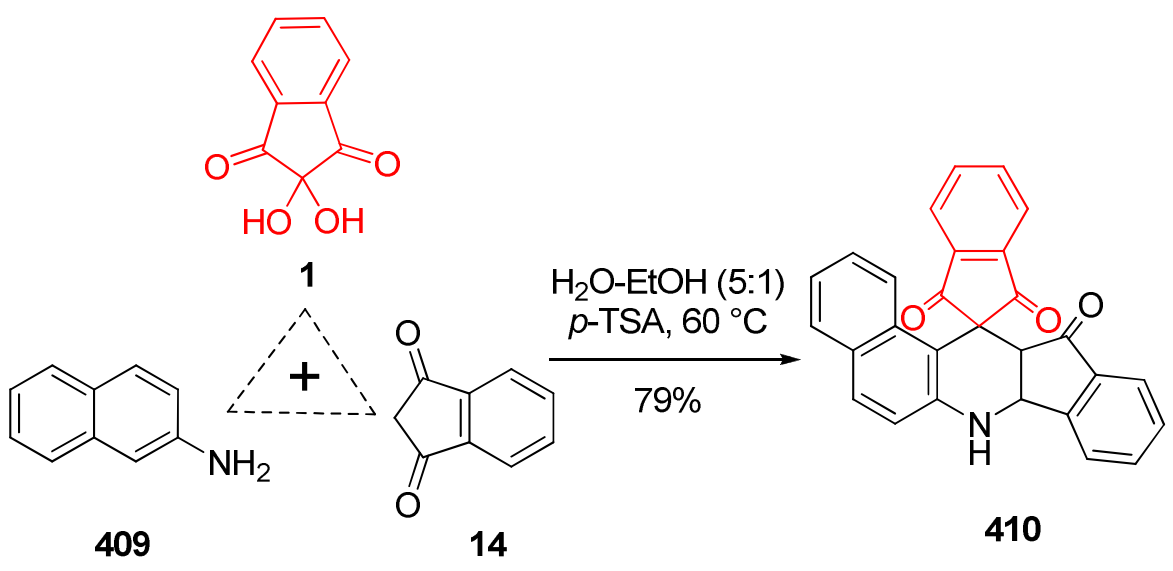

Scheme 133. Three-component synthesis of spiro $1 H$-indeno[1,2- $b]$ benzo[ $f]$ quinoline from ninhydrin, 1,3-indanedione, and naphthalene-2-amine.

Synthesis of a series of novel tetrahydroquinoline annulated heterocycles $\mathbf{4 1 3}$ was accomplished via a one-pot reaction of ninhydrin 1, p-bromoaniline 412, and dihydropyran 411 in the presence of indium trichloride as a catalyst and acetonitrile as solvent (Scheme 134). ${ }^{453}$ Compound $\mathbf{4 1 3}$ was evaluated for its antibacterial activity and exhibited promising antibacterial activity against microorganisms. It inhibited the growth of the pathogens particularly $P$. aeruginosa.

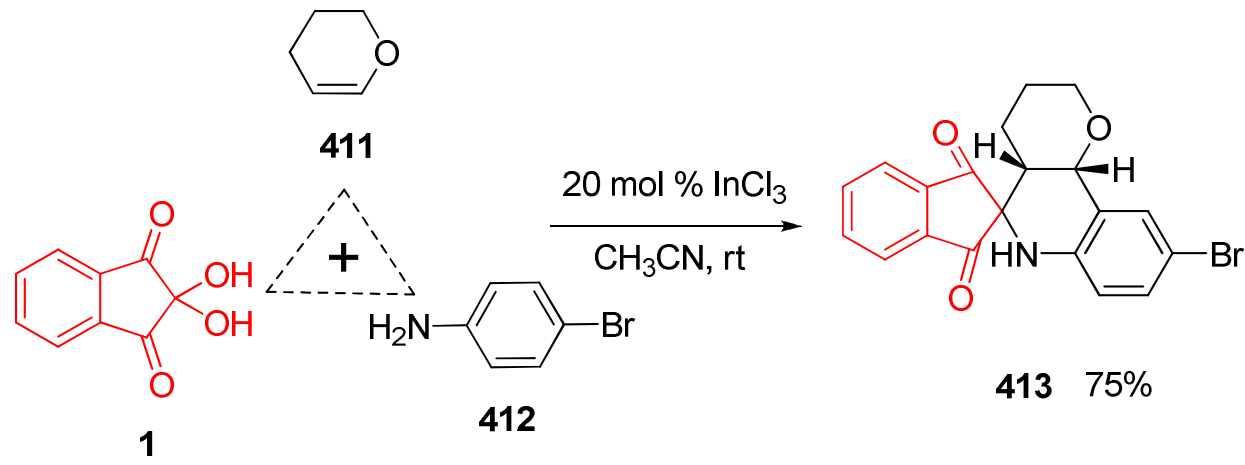

Scheme 134. Three-component synthesis of tetrahydroquinoline annulated heterocycles from ninhydrin, $p$-bromo aniline, and dihydropyran.

4.1.8. Isoquinolines. Isoquinolines, a type of alkaloids widely existing in materials used in traditional Chinese medicine, ${ }^{454}$ exhibit a variety of biological activities especially inhibition of cellular proliferation ${ }^{455}$ and cancer development. ${ }^{456-457}$ The reaction of phenylethylamines $\mathbf{4 1 4}$ with 
ninhydrin was investigated, with the expectation of one $\alpha$-amidoalkylation to the corresponding spirobenzyltetrahydroisoquinolines 415. ${ }^{458}$ However, when 3,4-dimethoxyphenylethylamine $\left(\mathrm{R}^{1}=\right.$ $\mathrm{OMe}, \mathrm{R}^{2}=\mathrm{H}$ ) was used as a reactant, the Pictet-Spengler intermediate $\mathbf{4 1 5}$ was not isolated, and theoxyprotoberberine $\mathbf{4 1 6}$ was directly obtained. Upon treatment with cupric acetate, the actual product isolated was oxyprotoberberine $\mathbf{4 1 7}$ (Scheme 135). ${ }^{459}$

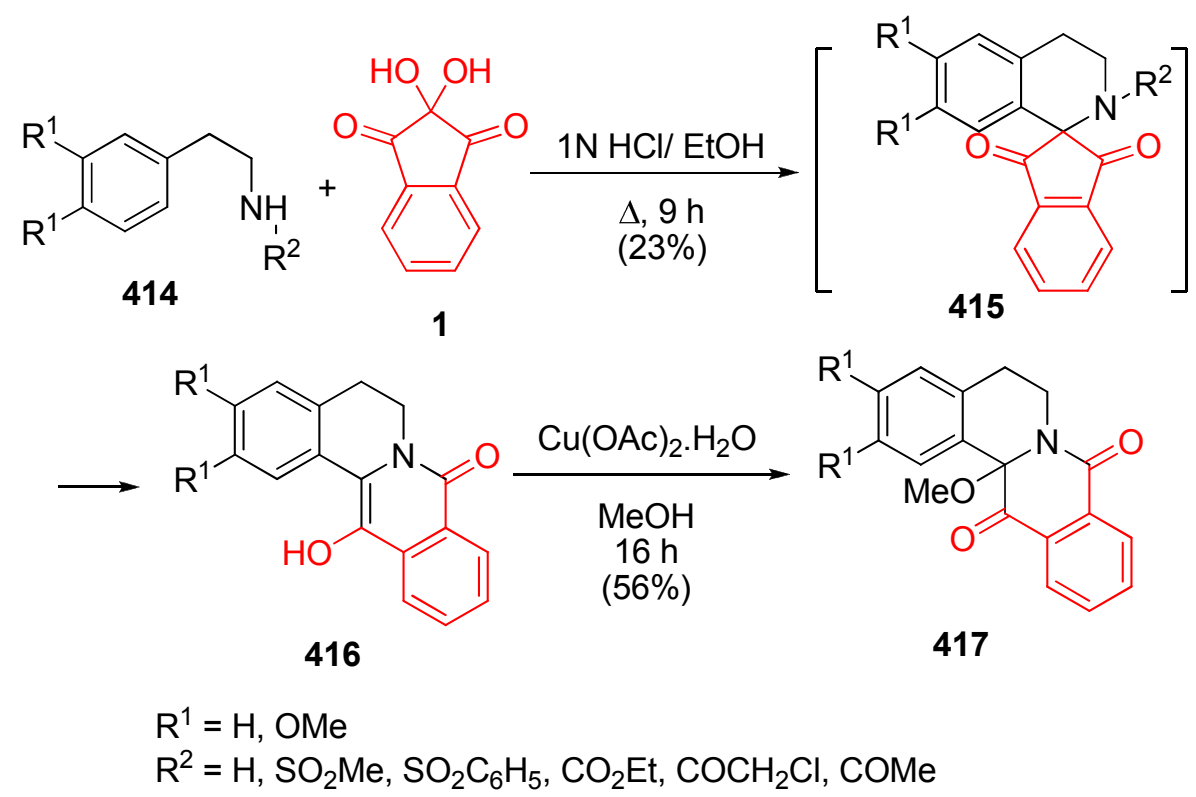

Scheme 135. Mechanism proposed for the reaction of phenylethylamines with ninhydrin.

Ninhydrin experiences an azido-Schmidt reaction with trimethylsilyl azide $\left(\mathrm{TMSN}_{3}\right)$ in the presence of $\mathrm{FeCl}_{3}$ under extremely mild conditions to provide isoquinoline-1,3,4-(2H)-trione 418 in good yield (Scheme 136). ${ }^{460}$<smiles>O=C1NC(=O)c2ccccc2C1=O</smiles>

Scheme 136. The azido-Schmidt reaction of ninhydrin with trimethylsilyl azide.

4.1.9. Pyridazines. Pyridazines are an important class of heterocycles, which have been the subject of extensive research, particularly in the pharmaceutical and agrochemical areas due to their broadactivities such as antimicrobial, ${ }^{461}$ antihypertensive, ${ }^{462}$ anti-inflammatory, ${ }^{463-464}$ and anticancer activities. ${ }^{465}$ The reaction of ninhydrin with acetaldehyde and ketones followed by the addition of hydrazine hydrate to give the corresponding 3-substituted $5 H$-indeno[1,2-c]-pyridazin-5-ones $\mathbf{4 2 0}$ was reported (Scheme 137). ${ }^{466}$ For example, employment of 3-acetylcoumarins $\mathbf{4 2 1}$ in this reaction 
with ninhydrin was investigated. ${ }^{467}$ It was found that a large series of $5 H$-indeno[1,2-c] -pyridazin5-ones 420 were shown to be competitive, reversible monoamine oxidase-A (MAO) inhibitors, with a relatively high selectivity for MAO-B. ${ }^{468}$

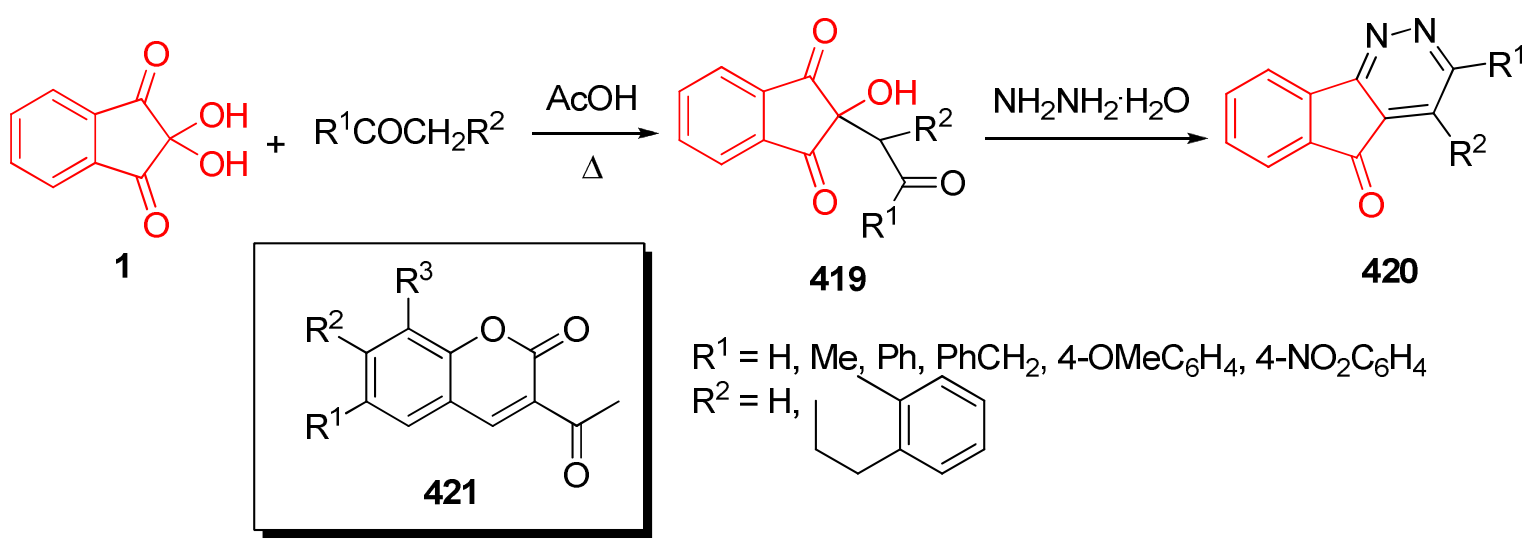

Scheme 137. Synthesis of $5 H$-indeno[1,2-c] -pyridazin-5-ones from ninhydrin and acetaldehyde or ketones.

Aminoantipyrin 422 condenses quantitatively with ninhydrin at room temperature in the solidstate to give product $\mathbf{4 2 3}$ in $100 \%$ yield. The ball-milling reaction of ninhydrin with cyanoacetohydrazide affords only the corresponding azomethine $\mathbf{4 2 4}$ in quantitative yield, which then cyclizes when refluxed in ethanol containing drops of triethylamine to give the corresponding indeno[2,1-c]pyridazine derivative $\mathbf{4 2 5}$ (Scheme 138). ${ }^{469}$<smiles>Cc1c(N)c(=O)n(-c2ccccc2)n1C</smiles>

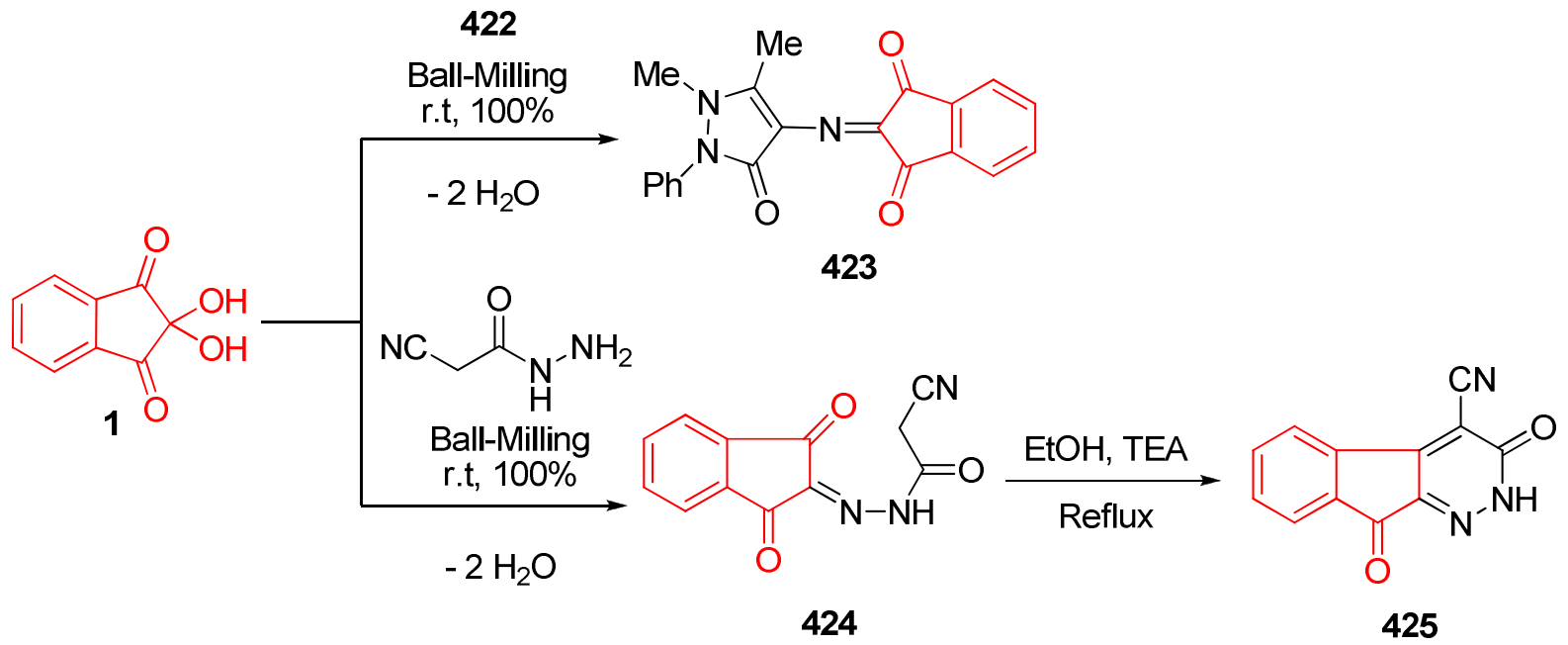

Scheme 138. Condensation of ninhydrin with aminoantipyrin and cyanoacetohydrazide. 


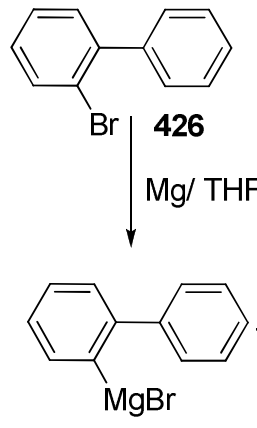

427

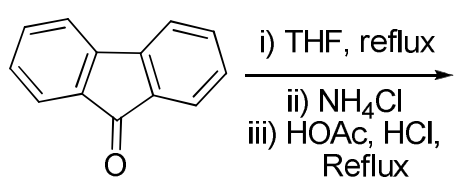

428<smiles>c1ccc2c(c1)-c1ccccc1C21c2ccccc2-c2ccccc21</smiles>

429 $\mathrm{AcCl} / \mathrm{AlCl}_{3} /$ $\mathrm{CS}_{2}$<smiles>[R4]C(O)[C@H](O)C(=O)O</smiles>

$430 a$<smiles>Cc1ccc2c(c1)C1(c3ccccc3-2)c2ccccc2-c2ccc(-c3cc4c(nn3)-c3ccccc3C4=O)cc21</smiles>

i) 2-Li-biphenyl THF, reflux ii) $\mathrm{NH}_{4} \mathrm{Cl}$

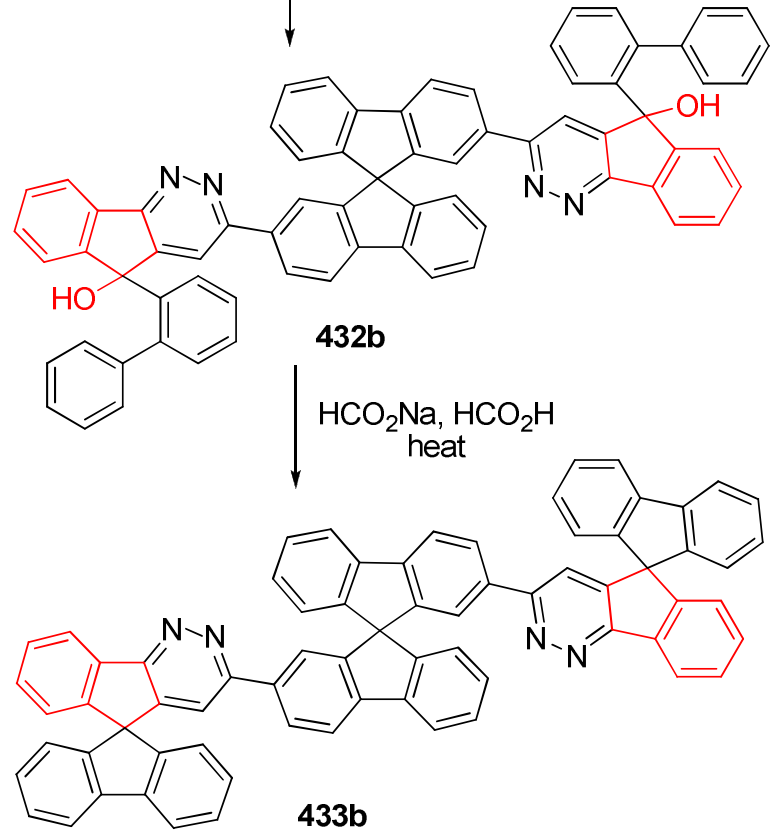<smiles>Cc1cc2c(nn1)-c1ccccc1C2=O</smiles>

430b<smiles>C/C=C\C1=CC=C(/C=C\C)C12c1ccccc1-c1ccc(-c3cc4c(nn3)-c3ccccc3C4=O)cc12</smiles>

i)

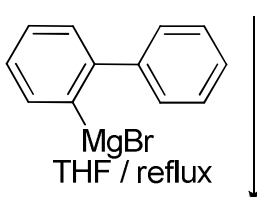

ii) $\mathrm{NH}_{4} \mathrm{Cl}$<smiles>Cc1cc2c(nn1)-c1ccccc1C2(O)c1ccccc1-c1ccccc1</smiles>

432a PPA, heat<smiles>c1ccc2c(c1)-c1ccccc1C21c2ccccc2-c2ccc(-c3cc4c(nn3)-c3ccccc3C43c4ccccc4-c4ccccc43)cc21</smiles>

433a

Scheme 139. Mechanistic explanation of the synthesis of a diaza-analogue of fluorenone and spirobifluorene. 
The effective synthesis of a diaza-analogue of fluorenone and spirobifluorene with a $\mathrm{N}=\mathrm{N}$ bond is achieved form the reaction of ninhydrin and the corresponding arene acetyl derivatives (Scheme 139). ${ }^{470-471}$ The Grignard reagent 427, prepared in situ from 2-bromobiphenyl $\mathbf{4 2 6}$ and $\mathrm{Mg}$ in THF, is then reacted with fluorenone $\mathbf{4 2 8}$ to form the tertiary fluoren-9-ol, which cyclizes with $\mathrm{HCl} / \mathrm{HOAc}$ to form spirobifluorene 429. Acylation of spirobifluorene with $\mathrm{AlCl}_{3}$ forms 2-acetyl spirobifluorene 430a and 2,2'-diacetylspirobifluorene 430b, which can easily be separated by column chromatography. The reaction of $430 \mathrm{a}$ or $430 \mathrm{~b}$ with ninhydrin and hydrazine hydrate in acetic acid under refluxing affords compounds 431a or $431 \mathrm{~b}$ containing the pyridazine fragments in good yields (70\% and $73 \%$ respectively). Again, when the Grignard reagent of 2-bromobiphenyl is reacted with compounds 431a or 431b, product 432a and 432b are isolated. While the ring closure reaction of 432a (racemic) can be completed with PPA and higher temperature, $\mathrm{HCO}_{2} \mathrm{Na} / \mathrm{HCO}_{2} \mathrm{H}$ gives better results. Compound $\mathbf{4 3 2 b}$ can be used to form compound $\mathbf{4 3 3 b}$ directly, due to difficulties with its purification.

4.1.10. Triazines. Various substituted triazines are known to exhibit a broad range of biological activity. ${ }^{472-474}$ They also show excellent photonic, and electronic properties due to the high electron affinity, and symmetrical structure. ${ }^{475-477} 9 H$-Indeno[1,2-e]-[1,2,4]-triazin-9-ones 436 are synthesized using ninhydrin and carboxamide hydrazones in $\mathrm{MeOH}^{478}$ or $\mathrm{EtOH}^{479}$ as well as $\mathbf{4 3 7 a - c}$ (Scheme 141). The $m$-nitrophenyl congener $437 \mathbf{c}$ is obtained in almost quantitative yield through a one-pot procedure, reacting ninhydrin and 3-nitrobenzenecarboximidohydrazide in refluxing EtOH for 30 min. Reduction of the nitro group in $437 \mathbf{c}$ with $\mathrm{SnCl}_{2}$ in $\mathrm{EtOH}$ yields the amino derivative $437 \mathbf{b}$, which is converted to the unsubstituted congener 437a through acid decomposition of the corresponding diazonium salt (Scheme 140). ${ }^{480}$ The synthesized compounds were evaluated in vitro as monoamine oxidase (MAO) A and B inhibitors, and showed inhibition potency toward MAO-B, the most effective one being 3-(3-nitrophenyl)-9H-indeno[1,2-e] [1,2,4]triazin-9-one 437c, which displayed an $\mathrm{IC}_{50}$ value of $80 \mathrm{nM}$.

El-Zahabi and co-workers made a series of 4-substituted s-triazino[1,2-a]benzimidazoles 439 from the reaction of 2-guanidinobenzimidazole $\mathbf{4 3 8}$ with ninhydrin (Scheme 141). ${ }^{481}$ The compounds synthesized were screened for their antibacterial activities against Staphylococcus aureus and Escherichia coli, with the conclusion being that moderate acidity is required for antibacterial activity of compound $\mathbf{4 3 9}$. 
<smiles>O=C1c2ccccc2C(=O)C1(O)O</smiles>

$+{ }_{\mathrm{N}}^{\mathrm{H}_{2} \mathrm{~N}}=<_{\mathrm{R}}^{\mathrm{NH}_{2}} \underset{-\mathrm{H}_{2} \mathrm{O}}{\stackrel{\mathrm{MeOH}}{\longrightarrow}}$<smiles>[R]C(N)=NNC1(O)C(=O)c2ccccc2C1=O</smiles><smiles>[R]C(N)=NN=c1c(=O)c2ccccc2c1=O</smiles>

1

435<smiles>[R]Cc1ccc(C)cc1</smiles><smiles>Cc1ccc2ccccc2c1</smiles><smiles>C1=CN=CCC1</smiles><smiles>[R]c1nnc2c(n1)-c1ccccc1C2=O</smiles>

436

\section{4}<smiles>[X]c1cccc(-c2nnc3c(n2)-c2ccccc2C3=O)c1</smiles>

437a-c

Scheme 140. Synthesis of $9 H$-indeno[1,2-e]-[1,2,4]-triazin-9-ones from ninhydrin and carboxamide hydrazones.<smiles>N=C(N)Nc1nc2ccccc2[nH]1</smiles>

438<smiles></smiles>

1<smiles>NC1=NC2(C(=O)c3ccccc3C2=O)n2c(nc3ccccc32)N1</smiles>

439

Scheme 141. reaction of 2-guanidinobenzimidazole with ninhydrin reported by El-Zahabi.

A recent patent describes the synthesis of pentaaza-cyclopenta[b]fluoren-9-ones 441 and 442 using substituted 1,2,4-triazole-3,4-diamines 440 and ninhydrin (Scheme 142). ${ }^{482-483}$ 


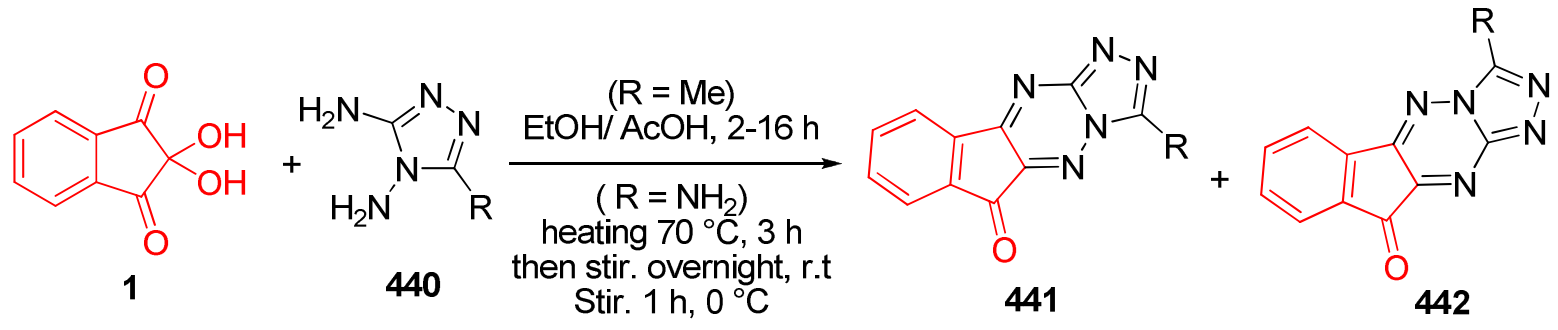

$\mathrm{R}=\mathrm{Me}, \mathrm{NH}_{2}$

Scheme 142. Synthesis of pentaaza-cyclopenta[b]fluoren-9-ones from ninhydrin and substituted 1,2,4-triazole-3,4-diamines.

\subsection{O-Heterocyclic compounds}

4.2.1. Pyrans. It is well known that pyran derivatives are an important class of heterocyclic compounds having a wide spectrum of pharmacological and biological activities, such as anti$\mathrm{HIV}^{484}$ anticancer, ${ }^{485}$ antileishmanial ${ }^{486}$ and anticonvulsant activities. ${ }^{487} \mathrm{~A}$ three-component condensation of malononitrile/ethyl cyanoacetate, 1,3-dicarbonyl compounds, and ninhydrin in water affords spiropyran-fused derivatives 443-445. The reaction can be catalyzed by the ionic liquid $\left[\mathrm{H}_{3} \mathrm{~N}^{+} \mathrm{CH}_{2} \mathrm{CH}_{2} \mathrm{OH}\right]\left[\mathrm{CH}_{3} \mathrm{COO}^{-}\right]$(HEAA) (Scheme 143), ${ }^{488}$ while similar products can be achieved by employing glycerol, ${ }^{489} \mathrm{CaCl}_{2},{ }^{490} \mathrm{DBU},{ }^{491}$ propane-1-sulfonic acid-modified magnetic hydroxyapatite nanoparticles, ${ }^{492}$ and alum. ${ }^{493}$<smiles>[R]c1ccc(C(C)=O)c(C(C)=O)c1</smiles>

Scheme 143. Three-component condensation of malononitrile/ethyl cyanoacetate, 1,3-dicarbonyl compounds, and ninhydrin. 
In a program aimed at finding novel compounds while retaining a major portion of the steroid nucleus for glucocorticoid-like activity, spiro[2H-indene[2,3']-3H-naphtho[2,1-b]]pyran-1,3,8'-trione 447 was prepared as a racemic mixture in $73 \%$ yield (Scheme 144). ${ }^{498}$<smiles>O=C1c2ccccc2C(=O)C1(O)O</smiles>

1<smiles>C=CC1=CCCC2=CC(=O)CC[C@@]12C</smiles>

446

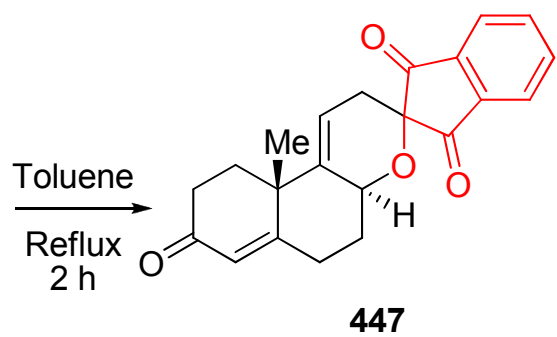

447

Scheme 144. Synthesis of spiro[2H-indene[2,3']-3H-naphtho[2,1-b]]pyran-1,3,8'-trione.

The hetero-Diels-Alder reaction of 2-methyl-1-(1-phenylalkoxy)-butadienes containing a chiral center with ninhydrin to afford 1-alkoxy-5,6-dihydro-2 $H$-pyrans 448 proceeds smoothly at room temperature in excellent yield and high diastereoselectivity. Only trans-epoxides 449 can be obtained from the diastereomeric mixtures of $\mathbf{4 4 8}$ using a freshly prepared solution of dimethyldioxirane in acetone (Scheme 145). ${ }^{499}$

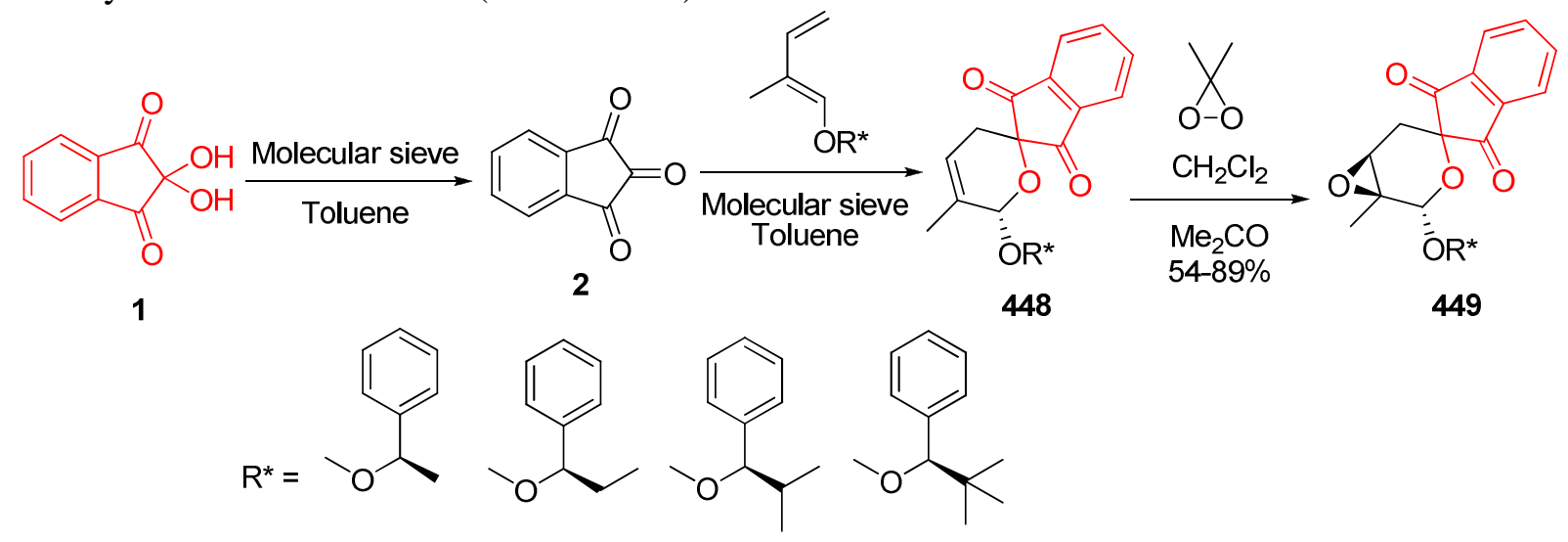

Scheme 145. Mechanism proposed for the hetero-Diels-Alder reaction of 2-methyl-1-(1phenylalkoxy)-butadienes with ninhydrin.

Synthesis of novel racemic 2'-aminospiro-[11H-indeno[1,2- $b$ ]quinoxaline-11,4'-[4H]pyran] derivatives 450 was achieved via the four-component reaction of ninhydrin 1, 1,2phenylenediamine 117, malono derivatives, and $\alpha$-methylenecarbonyl compounds in the presence of ammonium acetate as a neutral catalyst (Scheme 146). ${ }^{500}$ The same reaction was also catalyzed by indium (III) chloride. ${ }^{501}$ 


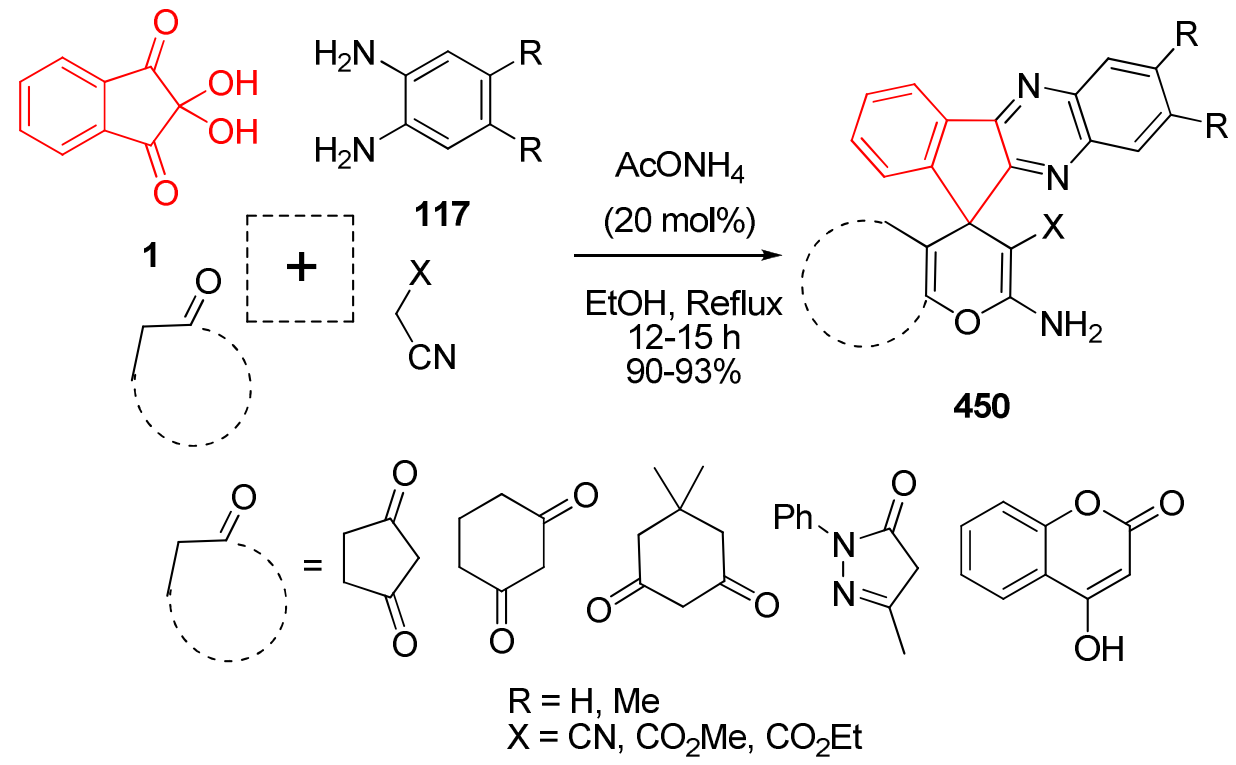

Scheme 146. Four-component synthesis of novel racemic 2'-aminospiro-[11H-indeno[1,2b]quinoxaline- 11,4'-[4H]pyran].

Perumal and co-workers reported that the Knoevenagel condensation product of $N$-methyl-4piperidone $\mathbf{4 5 1}$ and malononitrile dimerizes to form spiro-piperidinoisoquinoline $\mathbf{4 5 2}$, which attacks ninhydrin 1 to provide a spiro-framework containing the spiropiperidine ring $\mathbf{4 5 3}$ (Scheme 147). ${ }^{502}$<smiles>CCO/N=C\C(=O)OCC</smiles>

451 452

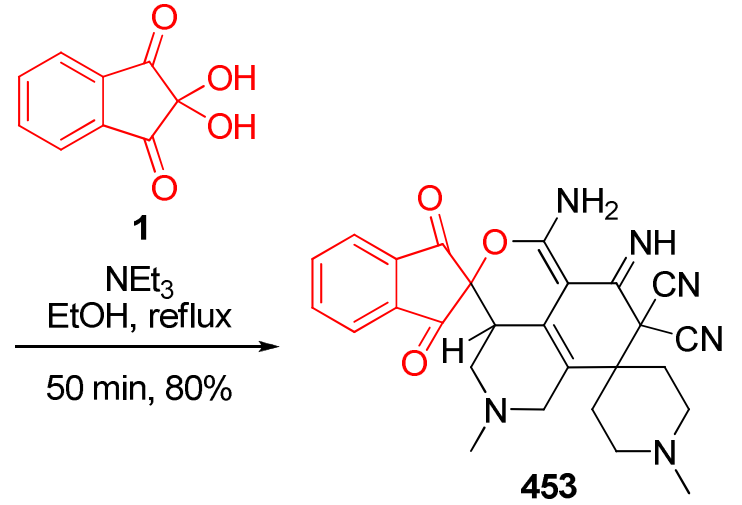

Scheme 147. Sequential one pot reaction of $N$-methyl-4-piperidone, malononitrile, and ninhydrin reported by Perumal. 
Bazgir and co-workers investigated the reaction between ninhydrin $\mathbf{1}$ and 2hydroxynaphthalene-1,4-dione $\mathbf{4 5 4}$, which resulted in the formation of meso spiro[dibenzo[b,i] xanthene-13,2'-indene]-1',3',5,7,12,14-hexaone 455 in 62\% yield (Scheme 148). ${ }^{503}$ Similarly, poly(4-vinylpyridinium)hydrogen sulfate was found to be an efficient catalyst in the same reaction. ${ }^{504}$

2<smiles>O=C1C(=O)c2ccccc2C(=O)C=C1O</smiles>

454<smiles>O=C1c2ccccc2C(=O)C1(O)O</smiles>

1

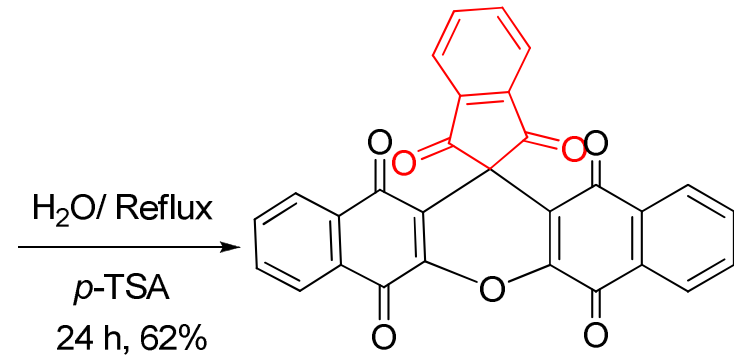

455

Scheme 148. Reaction of ninhydrin and 2-hydroxynaphthalene-1,4-dione reported by Bazgir.

The reaction of ninhydrin with tosylhydrazine to afford 2-diazo-1,3-indanedione $\mathbf{1 8}$ is known as the Bamford-Stevens reaction. ${ }^{505}$ The application of 2-diazo-1,3-indanedione $\mathbf{1 8}$ for the synthesis of 2-acyloxy-1,3-indanedione 456, meso 2-acyloxy-2'-hydroxy-1.3.1'.3'-tetraoxo-2.2'-diindanyl $\mathbf{4 5 8}$, racemic azo compounds $\mathbf{4 5 9}$ and meso 2-acyloxy-2-[xanthyl-(9)]-1,3-indanedione $\mathbf{4 6 0}$ was also investigated (Scheme 149). ${ }^{506}$<smiles>N#CC1C(=O)c2ccccc2C1=O</smiles><smiles>[R]C1([R])C(=O)c2ccccc2C1=O</smiles>

456

18<smiles>[R]C1(N=NC[N+](=O)[O-])C(=N)c2ccccc2C1=O</smiles>

459<smiles>O=C1c2ccccc2C(=O)C1(O)C1(O)C(=O)c2ccccc2C1=O</smiles><smiles>OC1c2ccccc2Oc2ccccc21</smiles>

$\mathrm{R}=\mathrm{CHO}, \mathrm{COMe}, \mathrm{COC}_{6} \mathrm{H}_{5}$, Tosyl

Scheme 149. Reaction of 2-acyloxy-1,3-indanedione with ninhydrin. 
Hetero-yohimbanone analogues 462 and 463 are synthesized using ninhydrin 1 and 3-acetyl7,12-dihydro-2-methyl-6H-indolo[2,3-a]quinolizinium chloride 461 (Scheme 150). ${ }^{507}$

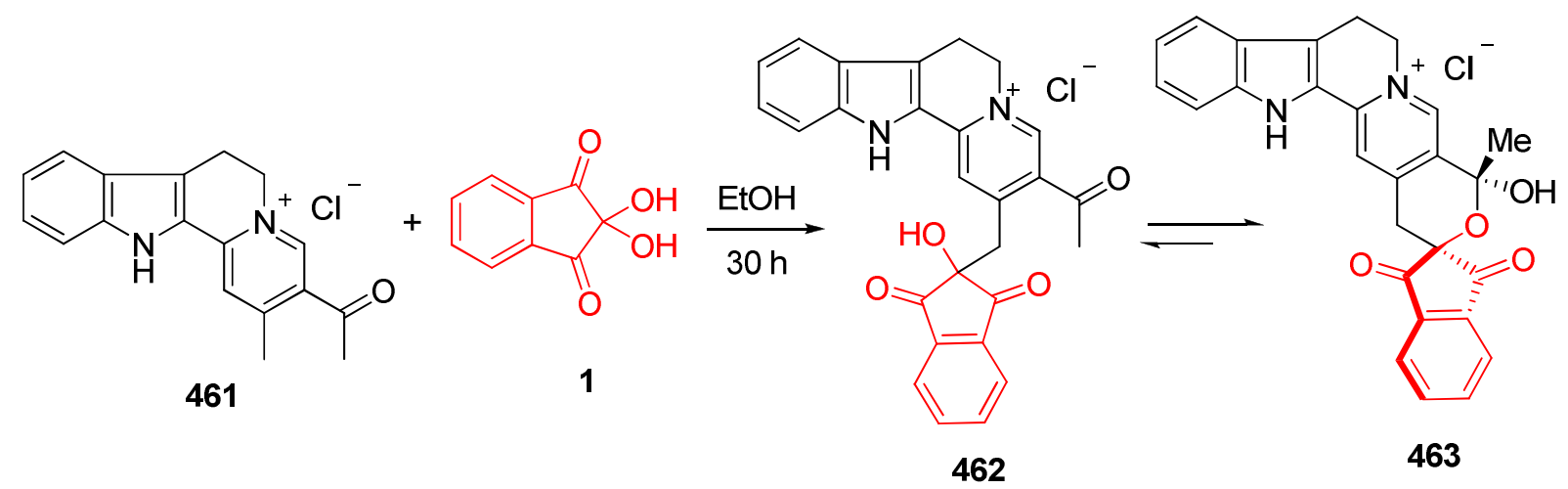

Scheme 150. Reaction of ninhydrin and 3-acetyl-7,12-dihydro-2-methyl-6H-indolo[2,3a]quinolizinium chloride.

4.2.2. Dioxanes. Dioxane rings are common structural motifs in many bioactive molecules. ${ }^{508-511}$ Numerous reactions between electron-rich, more- or less-polar enamines, such as 464, with ninhydrin 1 was reported by Schank and co-workers, and various new derivatives were formed (Scheme 151). ${ }^{512}$<smiles>O=C1c2ccccc2C(=O)C1(O)O</smiles>

1

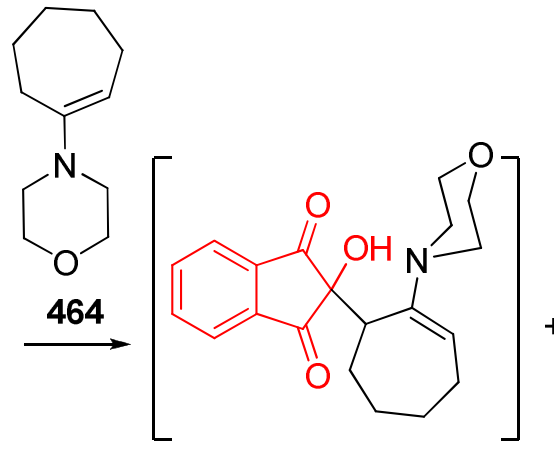

465<smiles>O=C1c2ccccc2C2(OC13CCCCCC3)OC1(CC2=O)C(=O)c2ccccc2C1=O</smiles>

466

Scheme 151. Reaction of ninhydrin and enamine reported by Schank.

\subsection{N,O-Heterocyclic compounds}

4.3.1. Oxazines. Various oxazine derivatives have shown a wide variety of bioactivities, such as anti-human coronavirus activity, ${ }^{513}$ inhibition of cholesterol esterase and acetylcholinesterase,${ }^{514}$ inhibition of human leukocyte elastase, ${ }^{515}$ and nonsteroidal progesterone receptor antagonists. ${ }^{516}$ The 1,3-dipolar intermediates generated by adding isoquinoline, quinoline, or pyridine to DMAD 41, are trapped by ninhydrin 1 to produce functionalized spiro compounds 469, 470, and 471, respectively (Scheme 152). ${ }^{517}$ 
<smiles></smiles>

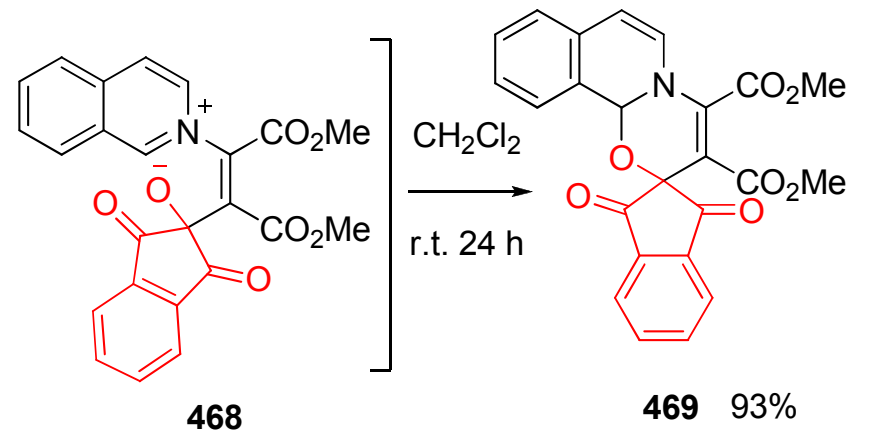<smiles>COC(=O)C1=C(C(=O)OC)C2(OC3C=CC=CN3C1C(=O)O)C(=O)c1ccccc1C2=O</smiles>

Scheme 152. Synthesis of functionalized spiro compounds from ninhydrin, DMAD, and isoquinoline, quinoline, or pyridine.

The reaction of 2-hydroxy-2-acylmethylene-1,3-indanedione $\mathbf{4 7 2}$ with tosyl chloride (TsCl) and anhydrous pyridine, isoquinoline, or phthalazine was reported (Scheme 153). ${ }^{518-519}$ A similar cyclocondensation reaction was observed by Carotti et al. when the aldol adduct $\mathbf{4 7 6}$ was treated with the same reagent under the similar experimental conditions to produce meso pyrido-oxazine derivatives 477 (Scheme 154). ${ }^{520}$ 


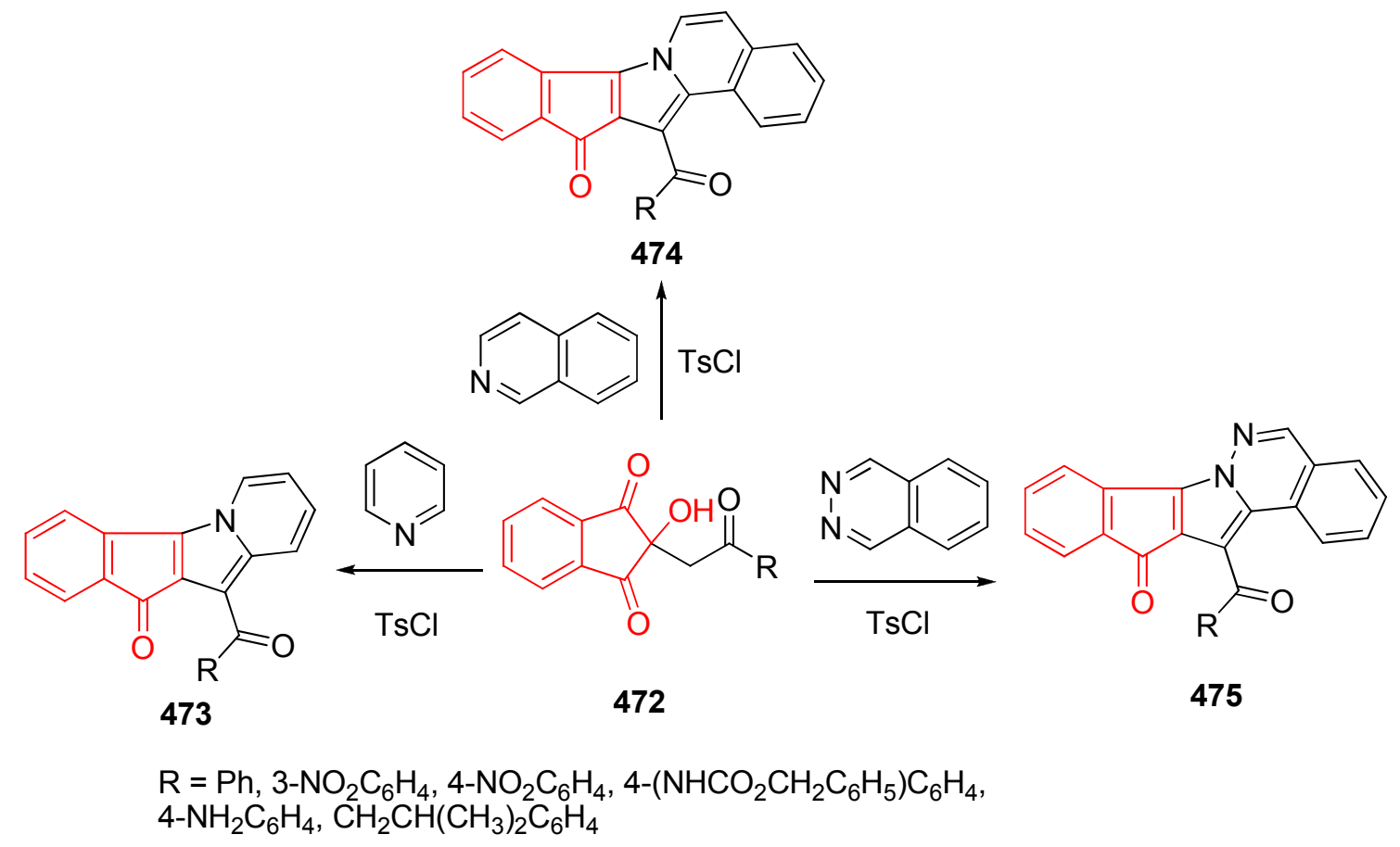

Scheme 153. Reaction of 2-hydroxy-2-acylmethylene-1,3-indanedione with pyridine, isoquinoline, or phthalazine.

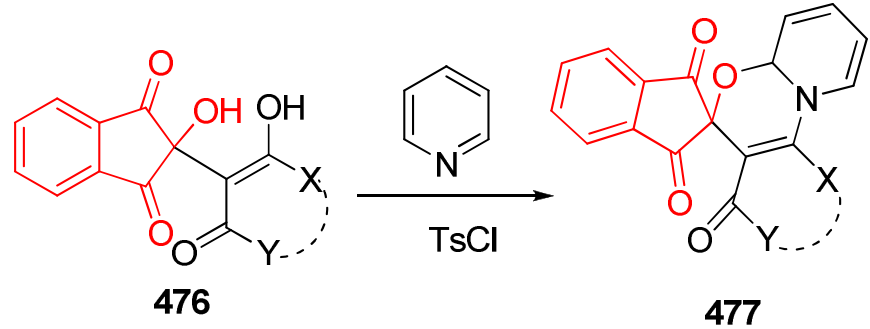

Scheme 154. Synthesis of pyrido-oxazine derivatives reported by Carotti.

The reaction products of ninhydrin and phenyl- and $p$-chlorophenyl-alanine were identified as racemic indeno-oxazinones 478 (Figure 4). ${ }^{521}$ The Fe(III), Cr(III) and Al(III) complexes of Schiff base ligands 479 derived from ninhydrin with some amino acids (glycine, alanine, and serine) were also prepared (Figure 4). ${ }^{522}$ 


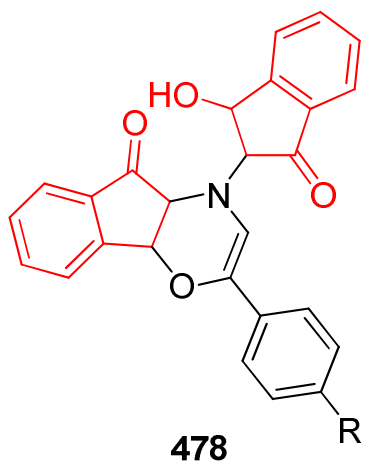

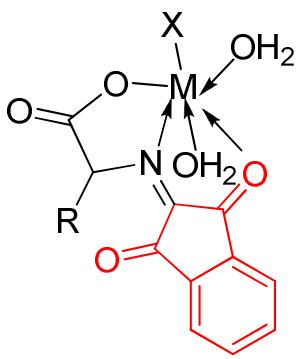

$\mathrm{R}=\mathrm{H}, \mathrm{Cl}$

479

$$
\begin{aligned}
& \mathrm{R}=\mathrm{H} \text { (gly), } \mathrm{Me} \text { (alan), } \mathrm{CH}_{2} \mathrm{OH} \text { (ser) } \\
& \mathrm{M}=\mathrm{Fe}(\mathrm{III}), \mathrm{Al}(\mathrm{III}), \mathrm{Cr}(\mathrm{III}) \\
& \mathrm{X}=\mathrm{Cl}, \mathrm{NO}_{3}
\end{aligned}
$$

Figure 4. Structure of oxazine derivatives of ninhydrin.

Recently, Pramanik's group developed a procedure for the synthesis of benzoxazinones $\mathbf{4 8 0}$ from 205 through an acid catalyzed rearrangement, followed by condensation with hydroxylamine (Scheme 155). ${ }^{523}$<smiles>[R]c1c([R])c([R])c2c(c1[R])OC1(O)c3ccccc3C(=O)OC21O</smiles><smiles>[R]c1c([R])c([R])c(C2(O)C(=O)c3ccccc3C2=O)c(O)c1[R]</smiles>

205<smiles>[R][R]([R])=Cc1cccc2c(C(=N)c3c([R4])c([R])c([R])c([R])c3O)noc(=O)c12</smiles>

Scheme 155. Synthesis of benzoxazinones reported by Pramanik.

\subsection{O,S-Heterocyclic compounds}

4.4.1. Oxathianes. Oxathianes are present as important core structures in many biologically active natural products ${ }^{524}$ and pharmaceuticals. ${ }^{525-526}$ In the reaction of ninhydrin $\mathbf{1}$ or indane-1,2,3-trione 2 with potassium thiotosylate, 1,4-oxathiin $\mathbf{4 8 5}$ was formed in up to $63 \%$ yield. Trapping the intermediate $\alpha, \alpha^{\prime}$-dioxothione $\mathbf{4 8 3}$ with $E$-cyclooctene $\mathbf{4 8 4}$ yielded the product. In addition, up to 
$18 \%$ of the available sulfur is transferred to alkene $\mathbf{4 8 4}$ to thiirane $\mathbf{4 8 2}$ through the intermediary oxathiirane (Scheme 156). ${ }^{527}$.

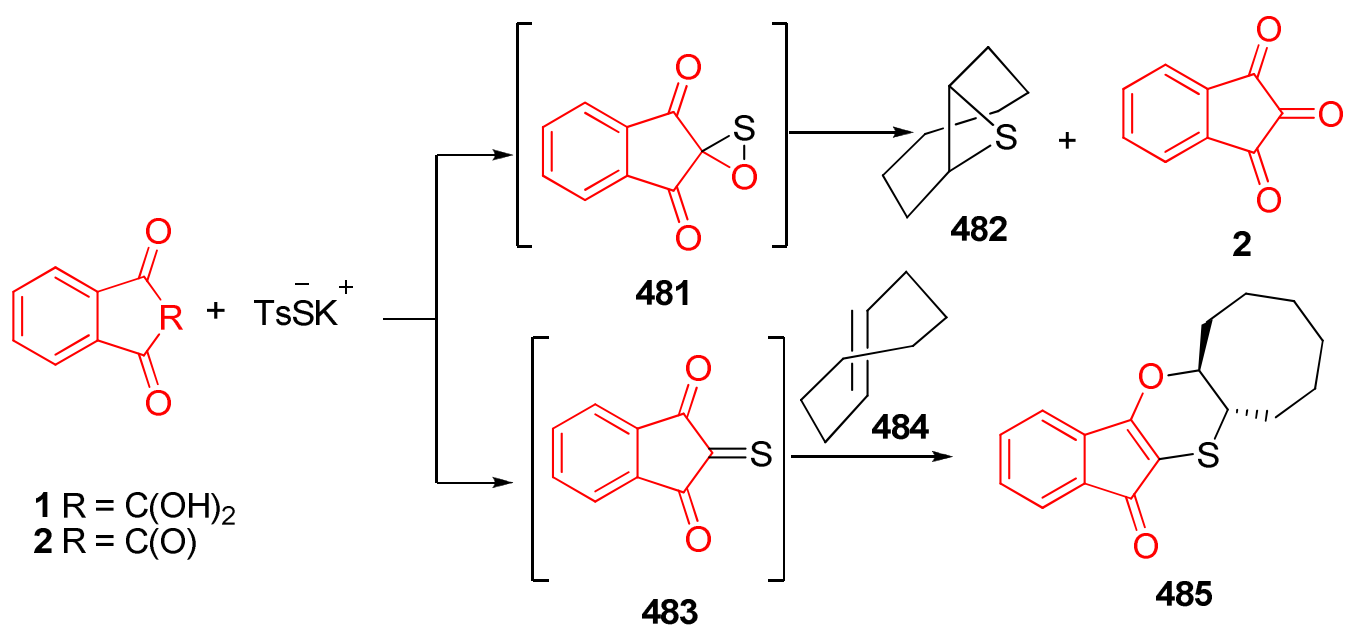

Scheme 156. Synthesis of 1,4-oxathiin from ninhydrin and potassium thiotosylate.

The reaction of ninhydrin with thiosalicylic acid $\mathbf{4 8 6}$ proceeded in trifluoroacetic acid to result in meso $4 H$-spiro(3,1-benzoxathiin-2,2'-indene)-1',3',4-trione $\mathbf{4 8 8}$ (Scheme 157). ${ }^{528}$

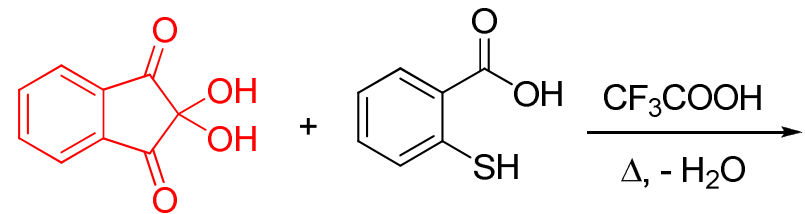

1

486

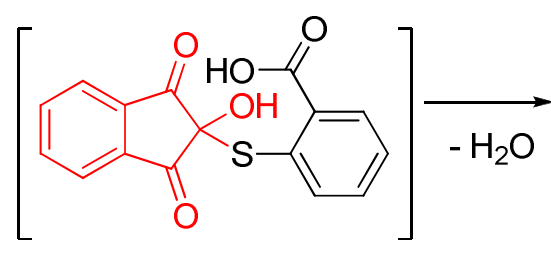

487<smiles>O=C1OC2(Sc3ccccc3C2=O)C(=O)c2ccccc21</smiles>

488

Scheme 157. Trifluoroacetic acid mediated synthesis of $4 H$-spiro(3,1-benzoxathiin-2,2'-indene)1',3',4-trione.

\section{Synthesis of Seven-membered Heterocycles}

This section presents some recent examples of the use of ninhydrin to prepare seven-membered heterocycles such as oxepines and diazepines. The reaction of ninhydrin with vinyl diazo 
compounds 489 afforded the spiroindan-1,3-dione-2,2'- benzodihydrooxepin 494. Normally, expected products from intermediate vinyl carbonyl ylides 491, such as oxirane and dihydrofuran derivatives, were not observed. Formation of $\mathbf{4 9 4}$ requires isomerization of vinyl carbonyl ylides 491 bearing a $(Z)$-cyanostyryl group to the unstable $(E)$-form 492 and subsequent cyclization to oxepin $\mathbf{4 9 3}$, followed by a 1,5-hydrogen shift (Scheme 158). ${ }^{529}$
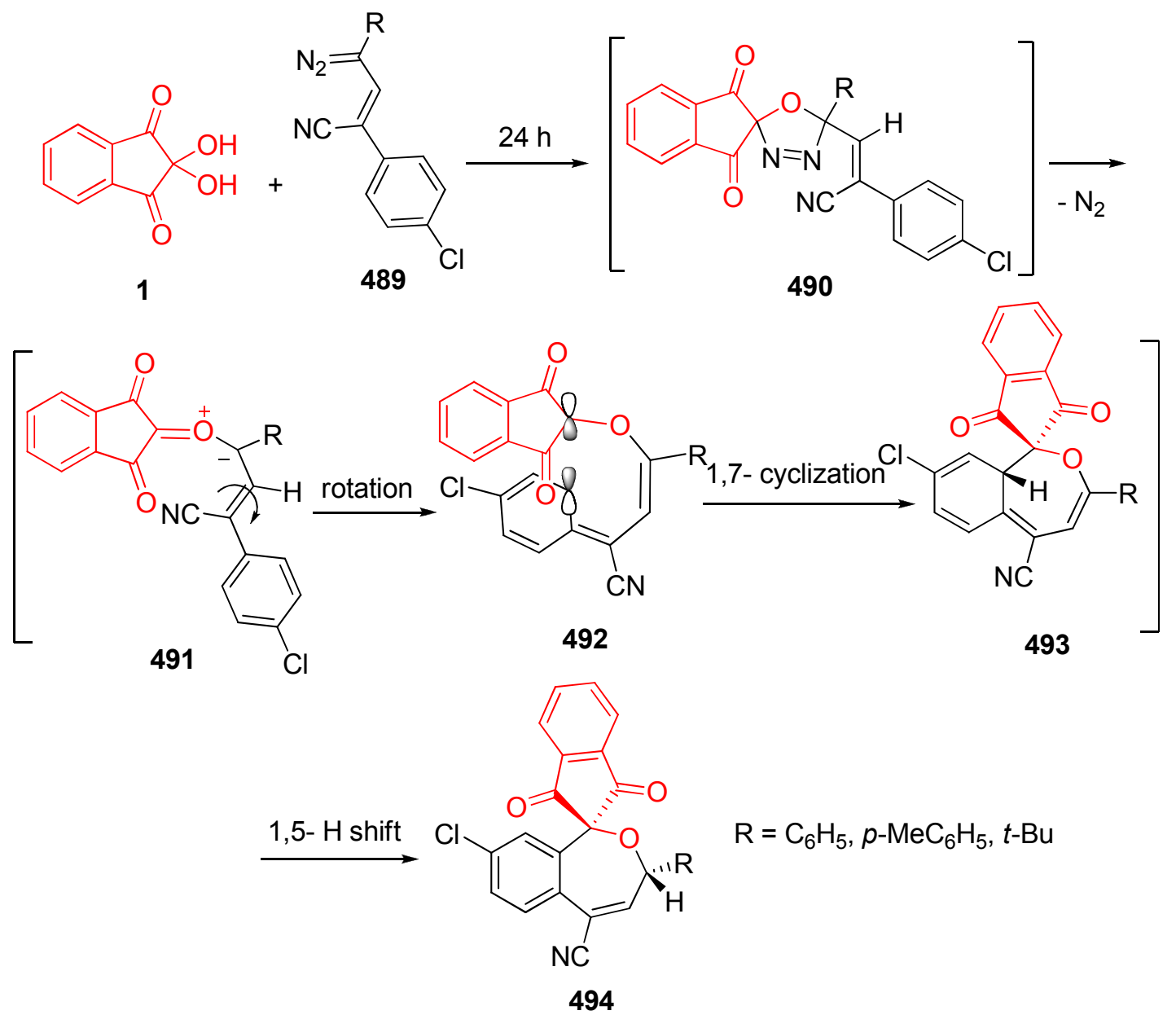

Scheme 158. Mechanistic explanation of the synthesis of spiroindane-1,3-dione-2,2'benzodihydrooxepin.

Spiro- $N, N$-ketal 498, consisting of a phthaloperine heterocyclic ring and a naphtho[1,8ef][1,4]diazepine ring, was obtained in addition to with spiro- $N, N$-ketal 495 via 2,2-condensation in the reaction of ninhydrin with naphthalene-1,8-diamine. Aside from these spiro compounds, the diazapleiadiene compound $\mathbf{4 9 6}$ forms from a 1,2-condensation reaction and the 1,4isoquinolinedione compound $\mathbf{4 9 7}$ arises from ring expansion, according to the report by Kobayashi and co-workers (Scheme 159). ${ }^{530}$ 

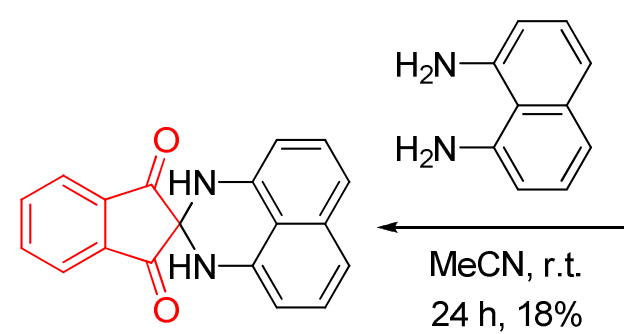<smiles>O=C1c2ccccc2C(=O)C1(O)O</smiles>

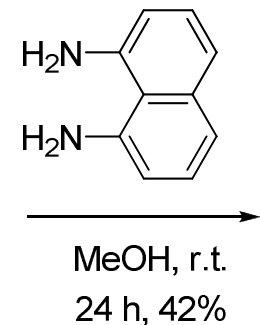

495<smiles>[R16][13CH3]</smiles>

$49723 \%$ 1<smiles>O=C1C2=Nc3cccc4cccc(c34)N=C2c2ccccc21</smiles>

496 $\mathrm{MeOH}, p-\mathrm{TSA}$ r.t., $24 \mathrm{~h}$<smiles>COC1=Nc2cccc3cccc(c23)NC12c1ccccc1C1=Nc3cccc4cccc(c34)N12</smiles>

$49838 \%$

Scheme 159. Reaction of ninhydrin with naphthalene-1,8-diamine.

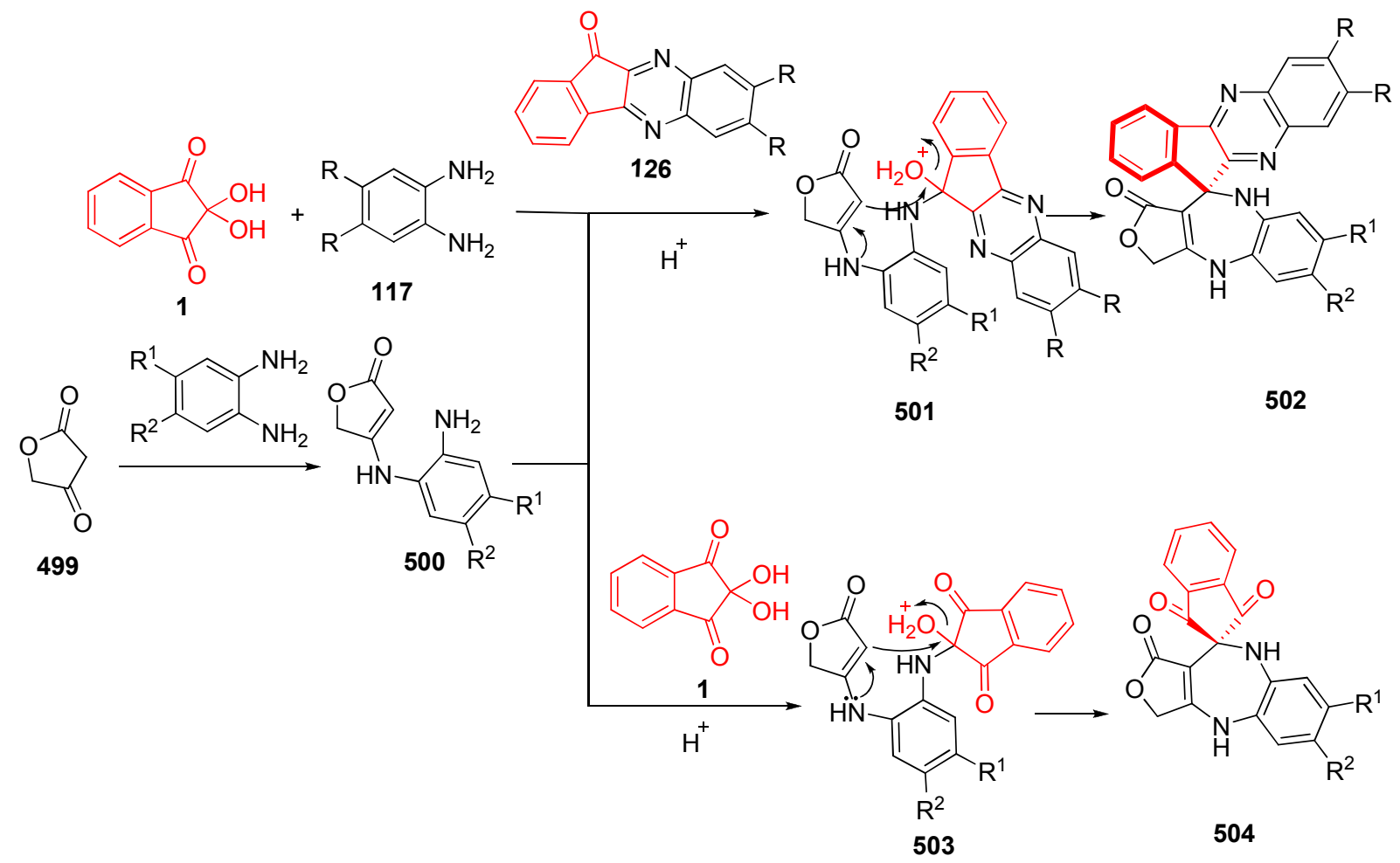

Scheme 160. Synthesis of spiro-substituted benzo[b]furo[3,4-e][1,4] diazepine derivatives. 
A new regio- and chemoselective $[4+2+1]$ domino cyclization reaction, consisting of the formation of two spiro rings, was developed for the synthesis of spiro-substituted benzo[b]furo[3,4e] $[1,4]$ diazepine derivatives (Scheme 160). ${ }^{531}$ The reaction is a multicomponent green domino process performed by reacting of $o$-phenylenediamines 117, tetronic acid 499 and ninhydrin 1 in aqueous solution under microwave irradiation. The mechanism of forming spiro-substituted benzo[b]furo[3,4-e][1,4] diazepine $\mathbf{5 0 2}$ and $\mathbf{5 0 4}$ is proposed as shown in Scheme 161. ${ }^{531}$ The former involves the ring closure cascade steps that consist of two condensations ( $\mathbf{1}$ to 126, and 499 to 500, respectively), an intermolecular nucleophilic addition (500 to 501) and an intramolecular nucleophilic substitution catalyzed by acetic acid (501 to 502). The latter involves the condensation reaction to give intermediate $\mathbf{5 0 0}$, which is followed by subsequent intermolecular nucleophilic addition with 1 (500 to 503) and intramolecular nucleophilic substitution (503 to 504).

Using the methoxy ketone derivative of oxyprotoberberine 417, a concise synthesis of the racemic isoindolobenzazepine aporhoeadane core 506 can be achieved (Scheme 161). ${ }^{532}$ This tetracyclic framework is rapidly assembled from simple precursors, and an alteration of the homoveratrylamine and ninhydrin building blocks readily allows for analogues to be prepared.

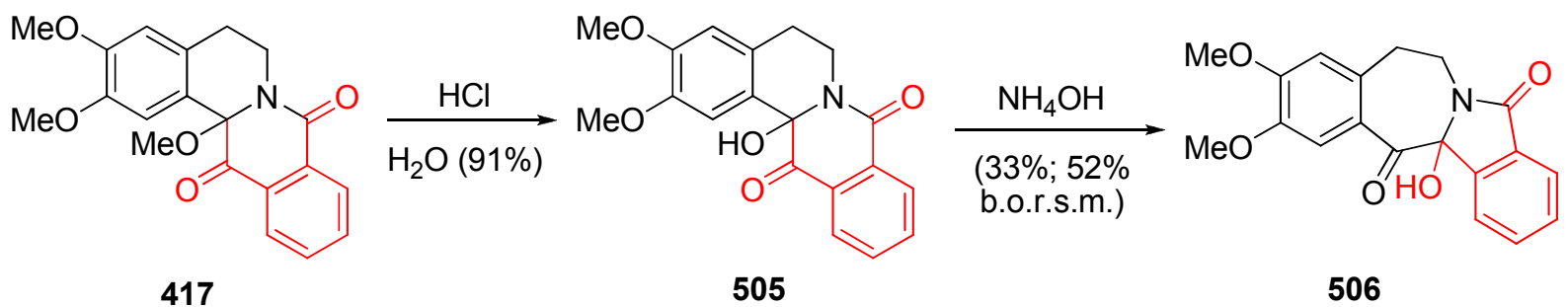

Scheme 161. Synthesis of isoindolobenzazepine aporhoeadane core.

Tolkunov's group reported the synthesis of new derivatives of dihydroquinazoline[3,2-c][2,3] benzodiazepine $\mathbf{5 0 8}$ using the Pictet-Spengler reaction of 3-amino-2-(3,4dimethoxybenzyl)quinazolin-4(3H)-one $\mathbf{5 0 7}$ with ninhydrin 1 (Scheme 162). ${ }^{533}$

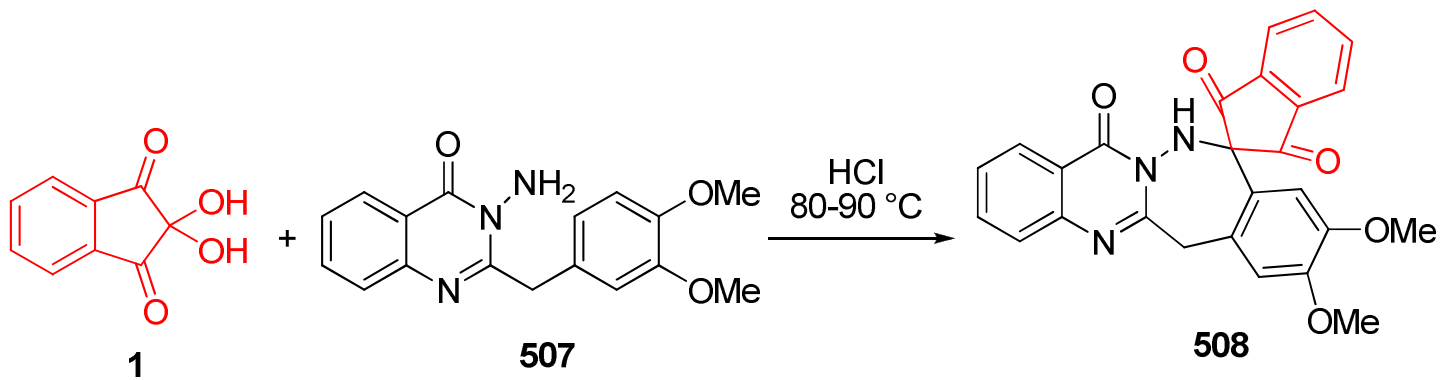

Scheme 162. Pictet-Spengler reaction of 3-amino-2-(3,4-dimethoxybenzyl)quinazolin-4(3H)-one with ninhydrin.

Ninhydrin reacts with cytosine, cytidine, and cytidine nucleotides to form products 510a-d (Scheme 163). ${ }^{534}$ The use of this reaction was suggested to modify cytosine residues of nucleic acids. Upon treatment with boiling acetic anhydride, followed by an aqueous work-up, acetylation 
of 510a affords a triacetyl derivative to which structure 511a was assigned. In another reaction, sodium metaperiodate cleaved 510a to give the carboxylic acid 512a.

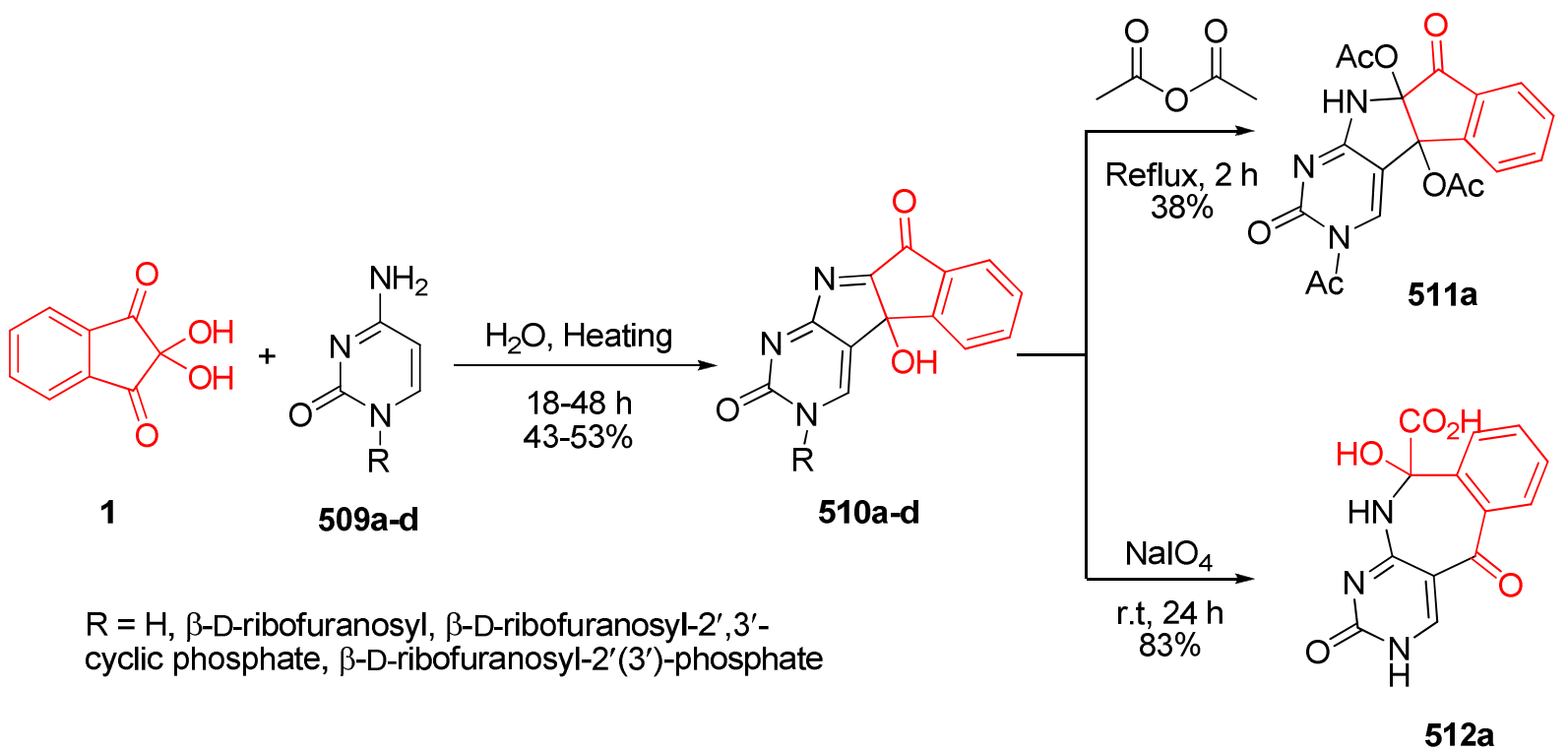

Scheme 163. Reaction of ninhydrin with cytosine, cytidine, and cytidine nucleotides.

Apart from seven-membered heterocycles, ninhydrin has been employed in the synthesis of eight-membered heterocycles that is discussed in the next section. Synthesis of azocines and diazocines is summarized in this section.

\section{Synthesis of Eight-membered Heterocycles}

In a modification of the Pictet-Spengler reaction, Tolkunov and co-workers successfully used compound 513 with ninhydrin for the synthesis of the eight-membered heterocyclic skeleton of tetrahydroquinazolino $[3,2-c][2,3]$ benzodiazocin-15-ones $\mathbf{5 1 4}$ (Scheme 164). ${ }^{535}$<smiles>COc1ccc(CCc2nc3ccccc3c(=O)n2N)cc1OC</smiles>

513<smiles>O=C1c2ccccc2C(=O)C1(O)O</smiles>

1<smiles>COc1cc2c(cc1OC)C1(CCc3nc4ccccc4c(=O)n3N1)C(=O)c1ccccc1C2=O</smiles>

514

Scheme 164. Synthesis of tetrahydroquinazolino [3,2-c][2,3]benzodiazocin-15-ones reported by Tolkunov.

In an interesting study, tetrahydro-3a,8b-dihydroxy-oxo-indeno[1,2- $b$ ]pyrroles $\mathbf{5 2}$ were prepared from ninhydrin and enamines, and then subjected to intramolecular Wittig reactions to afford 
dihydro- $1 H$-furo[2',3':2,3]cyclopenta[1,2-b]pyrroles 515. These fused 5,5-ring systems then experience $\mathrm{Et}_{3} \mathrm{~N}$-mediated fragmentation to afford tetrahydrobenzo[c]furo[3,2-e]-azocines $\mathbf{5 2 0}$ in good yields (Scheme 165). ${ }^{536}$

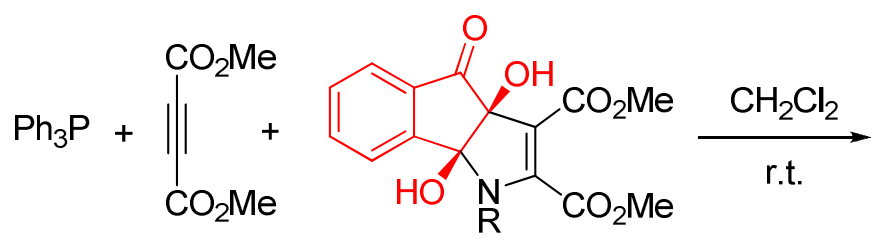

41

52<smiles>[R]OC(=O)C1=C(C(=O)OC)NC2(O)c3ccccc3C3=C(C(=O)OC)C(=O)OC132</smiles>

$515 \quad 74-88 \%$<smiles>COC(=O)C1=C(C(=O)OC)C2=C(C(=O)OC)C(C(=O)OC)(N1)c1ccccc12</smiles>

$\mathrm{Et}_{3} \stackrel{+}{\mathrm{N}} \mathrm{H}$ 516

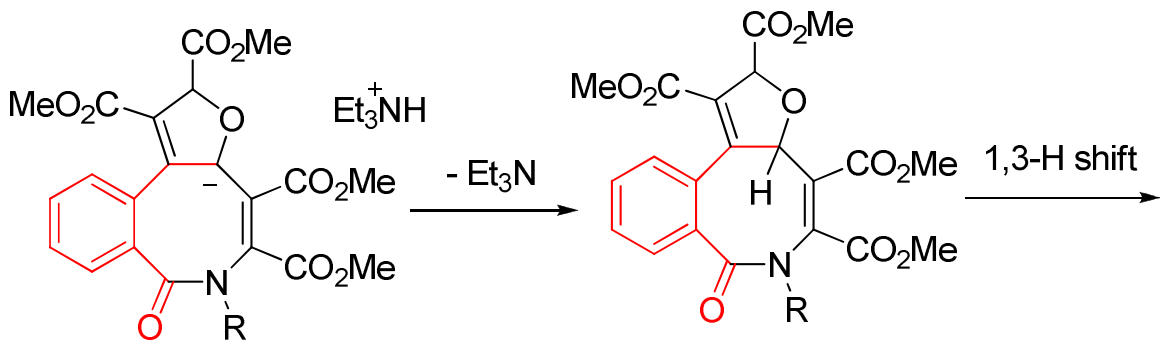

517

518<smiles>[R]N1C(=O)c2ccccc2C2=C(C(C)=O)C(C(C)=O)OC2=C1C(C)=O</smiles>

519<smiles>[R]N1C(=O)c2ccccc2-c2c(oc(C(C)=O)c2C(=O)OC)[C@H](O)[C@@H]1C(C)=O</smiles>

$520 \quad 75-86 \%$

$\mathrm{R}=\mathrm{Ph}, \mathrm{Bn}, \mathrm{Me}, n-\mathrm{Pr}, 2-\mathrm{ClC}_{6} \mathrm{H}_{4} \mathrm{CH}_{2}, 4-\mathrm{MeOC}_{6} \mathrm{H}_{4} \mathrm{CH}_{2}$

Scheme 165. Mechanism that accounts for the formation of tetrahydrobenzo[c]furo[3,2-e]-azocines.

Ninhydrin reacts with 1,3-indanedione 14 to generate a tetrone $\mathbf{2 5 4}$, which, on reaction with different substituted phenols under acidic conditions, forms substituted spirochromenes $\mathbf{5 2 1}$. When ethanolic solutions of these chromenes $\mathbf{5 2 1}$ are heated at reflux temperature with different aliphatic 
1,2-diamines, isoindole-fused eight-membered heterocyclic compounds $\mathbf{5 2 2}$ are formed in a completely diastereoselective manner (Scheme 166). ${ }^{537}$

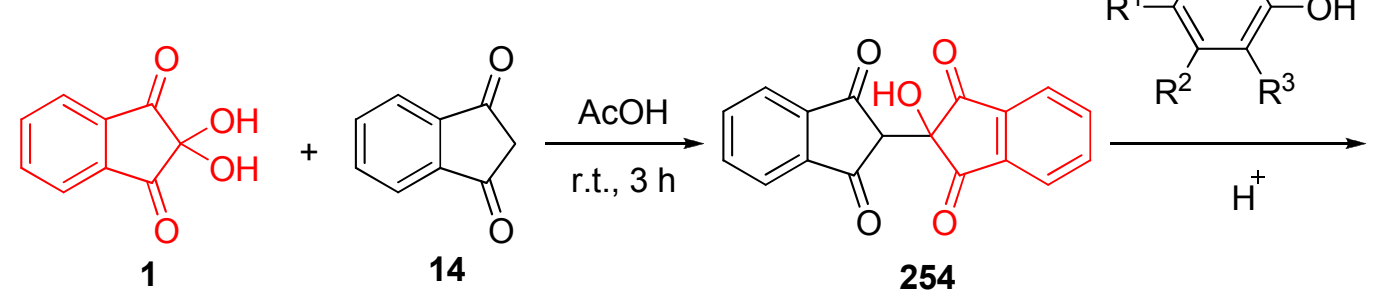

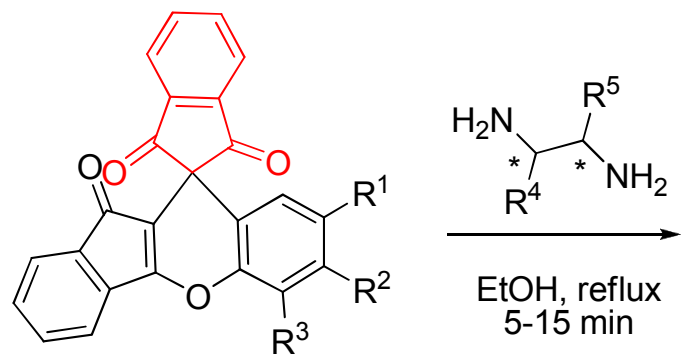

521

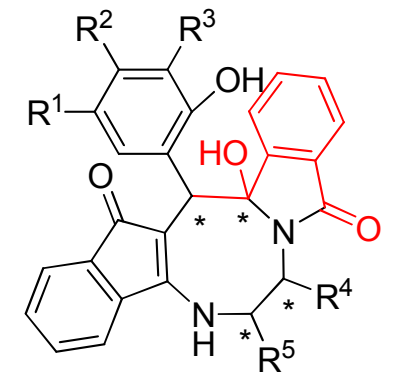

522

$\mathrm{R}^{1}, \mathrm{R}^{2}, \mathrm{R}^{3}=\mathrm{H}, \mathrm{Me}, \mathrm{F}, \mathrm{Cl}, \mathrm{I}, \mathrm{OMe}$

$\mathrm{R}^{4}=\mathrm{H},-\left(\mathrm{CH}_{2}\right)_{4}^{-}$

$\mathrm{R}^{5}=\mathrm{H}, \mathrm{Me},-\left(\mathrm{CH}_{2}\right)_{4}^{-}$

Scheme 166. Mechanistic explanation of isoindole-fused eight-membered heterocyclic compounds.

Condensation of $\mathbf{2 0 5}$ with ethylenediamine furnished the racemic eight-membered nitrogenous heterocycles $\mathbf{5 2 3}$ (Scheme 167). ${ }^{324}$

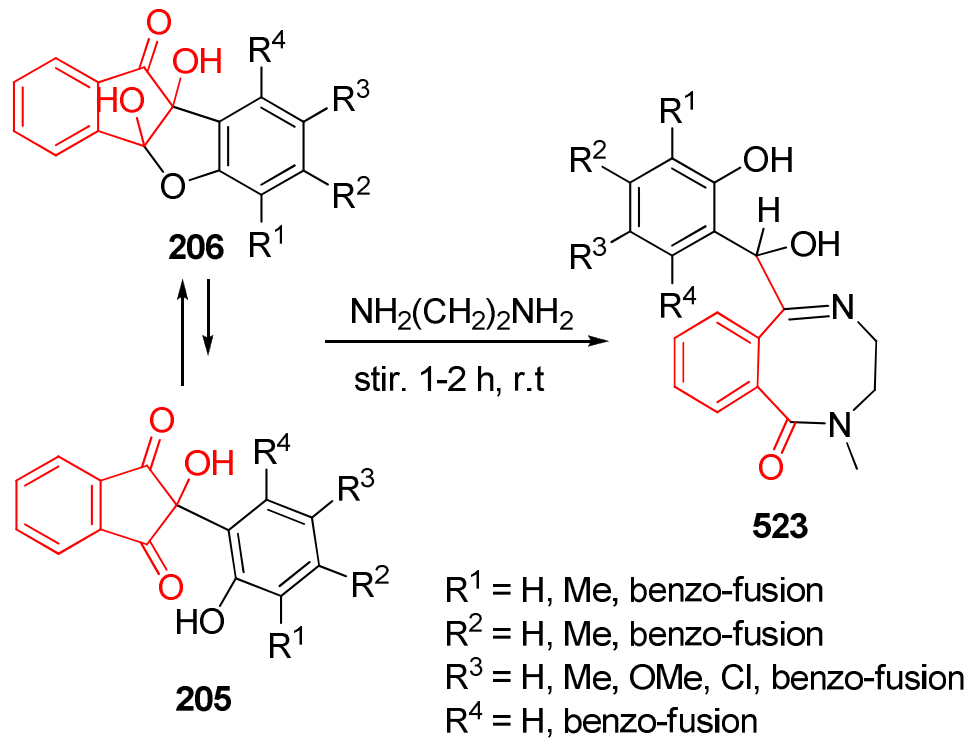

Scheme 167. Reaction of 2-hydroxy-2-aryl-1,3-indanediones with ethylenediamine reported by Pramanik. 


\section{Conclusion}

This review has summarized the use of ninhydrin in the synthesis of heterocyclic compounds with respect to the number of atoms in heterocyclic rings, taking into consideration the heteroatom. We have demonstrated that ninhydrin is a very versatile substrate, as it can be used for the synthesis of a large variety of heterocyclic compounds. The most significant applications of ninhydrin in organic synthesis are due to the more reactive $\mathrm{C}-2$ position of this compound, which is situated between two adjacent carbonyl groups. This C-2 group is highly reactive towards oxygen, sulfur and carbonbased nucleophiles. Different types of reactions, such as cycloaddition, cyclocondensation, Wittig, Pictet-Spengler, Baylis-Hillman, and several sequences of other reactions as well as multicomponent reactions were demonstrated for the synthesis of five- and six-membered heterocycles.

Ninhydrin has been used in two-, three-, and four-component reactions, leading to the formation of multiple heterocyclic frameworks. The use of ninhydrin to construct complex heterocycles through multicomponent reactions can provide a practical alternative to traditional methods of preparing such compounds, and the presented examples could serve as an inspiration to develop novel synthetic methods. Many challenges remain in this field to achieve more complex heterocycles, and we believe that this will be of great benefit for future investigators, including synthetic chemists, pharmacologists, and medicinal chemists. There is no doubt that ninhydrin will show more synthetic possibilities in the future, and that we can expect many developments of this template in synthetic chemistry.

\section{Acknowledgements}

We are grateful for financial support from the Research Council of Alzahra University.

\section{References}

1. Ruhemann, S. J. Chem. Soc., Trans. 1910, 97, 2025.

http://dx.doi.org/10.1039/ct9109702025

2. Ruhemann, S. J. Chem. Soc., Trans. 1910, 97, 1438.

http://dx.doi.org/10.1039/ct9109701438

3. Friedman, M.; Williams, L. D. Bioorg. Chem. 1974, 3, 267.

http://dx.doi.org/10.1016/0045-2068(74)90017-0

4. Wigfield, D. C.; Buchanan, G. W.; Croteau, S. M. Can. J. Chem. 1980, 58, 201. http://dx.doi.org/10.1139/v80-032

5. Moore, S.; Stein, W. H. J. Biol. Chem. 1948, 176, 367.

6. McCaldin, D. Chem. Rev. 1960, 60, 39.

http://dx.doi.org/10.1021/cr60203a004 
7. Schönberg, A.; Singer, E. Tetrahedron 1978, 34, 1285.

http://dx.doi.org/10.1016/0040-4020(78)88321-5

8. Hutzler, J.; Dancis, J. Clin. Chim. Acta 1983, 128, 75.

http://dx.doi.org/10.1016/0009-8981(83)90057-8

9. Joullie, M. M.; Thompson, T. R.; Nemeroff, N. H. Tetrahedron 1991, 47, 8791.

http://dx.doi.org/10.1016/S0040-4020(01)80997-2

10. Hansen, D. B.; Joullié, M. M. Chem. Soc. Rev. 2005, 34, 408.

http://dx.doi.org/10.1039/B315496N

11. Oden, S.; von Hofsten, B. Nature 1954, 173, 449.

http://dx.doi.org/10.1038/173449a0

12. Schonberg, A.; Moubacher, R. Chem. Rev. 1952, 50, 261.

http://dx.doi.org/10.1021/cr60156a002

13. Kay, J.; Rowland, F. J. Org. Chem. 1959, 24, 1800.

http://dx.doi.org/10.1021/jo01093a614

14. Friedman, M.; Sigel, C. W. Biochemistry 1966, 5, 478.

http://dx.doi.org/10.1021/bi00866a012

15. Wittmann, H.; Müller, A.; Ziegler, E. Monatsh. Chem. 1969, 100, 497.

http://dx.doi.org/10.1007/bf00904093

16. Wittmann, H.; Müller, A.; Ziegler, E. Monatsh. Chem. 1970, 101, 1388.

http://dx.doi.org/10.1007/bf00911404

17. Lamothe, P. J.; McCormick, P. G. Anal. Chem. 1973, 45, 1906.

http://dx.doi.org/10.1021/ac60333a021

18. Crout, D. H. G.; Piper, I. M.; Sehgal, C. K. Phytochemistry 1987, 26, 1399.

http//:dx.doi.org/10.1016/S0031-9422(00)81821-X

19. Fitzi, R.; Seebach, D. Tetrahedron 1988, 44, 5277.

http://dx.doi.org/10.1016/S0040-4020(01)86036-1

20. Kang, S.; Heo, S.; Lubec, G. Amino Acids 2013, 45, 1003.

http://dx.doi.org/10.1007/s00726-013-1513-1

21. Payne, G.; Reedy, B.; Lennard, C.; Comber, B.; Exline, D.; Roux, C. Forensic Sci. Int. 2005, $150,33$.

http://dx.doi.org/10.1016/j.forsciint.2004.06.036

22. Petraco, N. D. K.; Proni, G.; Jackiw, J. J.; Sapse, A.-M. J. Forensic Sci. 2006, 51, 1267. http://dx.doi.org/10.1111/j.1556-4029.2006.00271.x

23. Bicknell, D. E.; Ramotowski, R. S. J. Forensic Sci. 2008, 53, 1108. http://dx.doi.org/10.1111/j.1556-4029.2008.00826.x

24. Carter, D. O.; Yellowlees, D.; Tibbett, M. J. Forensic Sci. 2008, 53, 397. http://dx.doi.org/10.1111/j.1556-4029.2008.00681.x

25. Jasuja, O. P.; Toofany, M. A.; Singh, G.; Sodhi, G. S. Sci. Justice 2009, 49, 8. http://dx.doi.org/10.1016/j.scijus.2008.08.001

26. Clutter, S. W.; Bailey, R.; Everly, J. C.; Mercer, K. J. Forensic Sci. 2009, 54, 1332. http://dx.doi.org/10.1111/j.1556-4029.2009.01143.x 
27. Almog, J.; Glasner, H. J. Forensic Sci. 2010, 55, 215. http://dx.doi.org/10.1111/j.1556-4029.2009.01231.x

28. Schwarz, L.; Klenke, I. J. Forensic Sci. 2010, 55, 1076. http://dx.doi.org/10.1111/j.1556-4029.2010.01383.x

29. Schulz, M. M.; Brune, V.; Maierthaler, M.; Graw, M. Forensic Sci. Int. 2011, 3, e530. http://dx.doi.org/10.1016/j.fsigss.2011.09.115

30. Porpiglia, N.; Bleay, S.; Fitzgerald, L.; Barron, L. Sci. Justice 2012, 52, 42. http://dx.doi.org/10.1016/j.scijus.2011.04.006

31. Berdejo, S.; Rowe, M.; Bond, J. W. J. Forensic Sci. 2012, 57, 509. http://dx.doi.org/10.1111/j.1556-4029.2011.01972.x

32. Anderson, B.; Meyer, J.; Carter, D. O. J. Forensic Sci. 2013, 58, 1348. http://dx.doi.org/10.1111/1556-4029.12230

33. Kabir ud, D.; Salem, J. K. J.; Kumar, S.; Rafiquee, M. Z. A.; Khan, Z. J. Colloid Interface Sci. 1999, 213, 20. http://dx.doi.org/10.1006/jcis.1999.6085

34. Kabir ud, D.; Salem, J. K. J.; Kumar, S.; Khan, Z. J .Colloid Interface Sci. 1999, 215, 9. http://dx.doi.org/10.1006/jcis.1999.6211

35. Din, K.-u.; Salem, J. K. J.; Kumar, S.; Khan, Z. Colloids Surf., A 2000, 168, 241. http://dx.doi.org/10.1016/S0927-7757(99)00454-9

36. Kabir ud, D.; Fatma, W.; Khan, Z .Int. J. Chem. Kinet. 2006, 38, 634. http://dx.doi.org/10.1002/kin.20197

37. Kabir ud, D.; Fatma, W. J. Phys. Org. Chem. 2007, 20, 440. http://dx.doi.org/10.1002/poc.1171

38. Hark, R. R.; Hauze, D. B.; Petrovskaia, O.; Joullié, M. M. Can. J. Chem. 2001, 79, 1632. http://dx.doi.org/10.1139/v01-143

39. Courant, J.; Leblois, D.; Tandon, M.; Robert-Piessard, S.; Le Baut, G.; Juge, M.; Petit, J.-Y.; Welin, L. Eur. J. Med. Chem. 1989, 24, 145. http://dx.doi.org/10.1016/0223-5234(89)90108-6

40. Qureshi, S.; Al-Shabanah, O. A.; Al-Bekairi, A. M.; Al-Harbi, M. M.; Al-Gharably, N. M.; Raza, M. Invest. New Drugs 2000, 18, 221. http://dx.doi.org/10.1023/A:1006465504723

41. Prabhakar, K. R.; Veerapur, V. P.; Bansal, P.; Vipan, K. P.; Reddy, K. M.; Barik, A.; Reddy, B. K. D.; Reddanna, P.; Priyadarsini, K. I.; Unnikrishnan, M. K. Bioorg. Med. Chem. 2006, $14,7113$.

http://dx.doi.org/10.1016/j.bmc.2006.06.068

42. Khalil, A. M.; Berghot, M. A.; Gouda, M. A. Eur. J. Med. Chem. 2009, 44, 4434. http://dx.doi.org/10.1016/j.ejmech.2009.06.002

43. Catto, M.; Aliano, R.; Carotti, A.; Cellamare, S.; Palluotto, F.; Purgatorio, R.; De Stradis, A.; Campagna, F. Eur. J. Med. Chem. 2010, 45, 1359. http://dx.doi.org/10.1016/j.ejmech.2009.12.029 
44. Mahendran, S.; Badami, S.; Ravi, S.; Thippeswamy, B. S.; Veerapur, V. P. Pharm. Chem. J. 2011, 45, 547.

http://dx.doi.org/10.1007/s11094-011-0676-x

45. Lakshmi, N. V.; Sivakumar, P. M.; Muralidharan, D.; Doble, M.; Perumal, P. T. RSC Adv. 2013, 3, 496.

http://dx.doi.org/10.1039/c2ra01215d

46. Rahman, N.; Azmi, S. N. H. Il Farmaco 2001, 56, 731.

http://dx.doi.org/10.1016/S0014-827X(01)01093-X

47. Rahman, N.; Kashif, M. Il Farmaco 2003, 58, 1045.

http://dx.doi.org/10.1016/S0014-827X(03)00184-8

48. Leane, M. M.; Nankervis, R.; Smith ,A.; Illum, L. Int. J. Pharm. 2004, 271, 241.

http://dx.doi.org/10.1016/j.ijpharm.2003.11.023

49. Bhaskara, B. L.; Nagaraja, P. Helv. Chim. Acta 2006, 89, 2686.

http://dx.doi.org/10.1002/hlca.200690240

50. Xu, Z.; Xu, T.; Cheng, Y.; Ma, M.; Xu, P.; Qu ,H.; Wen, L. Anal. Lett. 2008, 41, 444. http://dx.doi.org/10.1080/00032710701484350

51. Ravi Kumar, H.; Ananda, S.; Devaraju, K. S.; Prakash, B. M.; Sampath Kumar, S.; Suresh Babu, S. V.; Ramachandraswamy, N.; Puttaraju, H. P. Indian J. Clin. Biochem. 2009, 24, 275.

http://dx.doi.org/10.1007/s12291-009-0052-8

52. Hinterwirth, H.; Strobl, M.; Al-Dubai, H. Monatsh. Chem. 2010, 141, 291. http://dx.doi.org/10.1007/s00706-010-0251-2

53. Siddiqui, F. A.; Arayne, M. S.; Sultana, N.; Qureshi, F.; Mirza, A. Z.; Zuberi, M. H.; Bahadur, S. S.; Afridi, N. S.; Shamshad, H.; Rehman, N. Eur. J. Med. Chem. 2010, 45, 2761.

http://dx.doi.org/10.1016/j.ejmech.2010.02.058

54. Li, Z.; Chang, S.; Lin, L.; Li, Y.; An, Q. Lett. Appl. Microbiol. 2011, 53, 178.

http://dx.doi.org/10.1111/j.1472-765X.2011.03088.x

55. Subramanian, N.; Devipriyadharshini, T.; Venkateshwaran, K.; Chandrasekar, P. Int. J. Pharm. Biomed. Res. 2011, 2, 26.

56. Kishore, M.; Hanumantharao, Y. J. Chem. Pharm. Res. 2012, 2, 99.

57. Khan, R.; Shah, J.; Rasul Jan, M. J. Anal. Chem. 2012, 67, 581.

http://dx.doi.org/10.1134/s1061934812060147

58. Pandey, E.; Upadhyay, S. K. J. Dispersion Sci. Technol. 2006, 27, 213.

http://dx.doi.org/10.1080/01932690500266993

59. Arayne, M. S.; Sultana, N.; Siddiqui, F. A.; Mirza, A. Z.; Zuberi, M. H. J. Mol. Struct. 2008, $891,475$.

http://dx.doi.org/10.1016/i.molstruc.2008.04.026

60. Matthies, D.; Hain, K. Synthesis 1973, 1973, 154.

http://dx.doi.org/10.1055/s-1973-22153

61. Bespalov, B. P.; Abolin, A. G. Chem. Heterocycl. Compd. 1982, 18, 379. 
http://dx.doi.org/10.1007/bf00503557

62. Isbell, H. S.; Frush, H. L.; Orhanovic, Z. Carbohydr. Res. 1975, 43, 93. http://dx.doi.org/10.1016/S0008-6215(00)83975-0

63. Puttaswamy; Ramachandrappa, R. Indian J. Chem. 1999, 38, 1272.

64. Kojima, M.; Toda, F.; Hattori, K. Tetrahedron Lett. 1980, 21, 2721. http://dx.doi.org/10.1016/S0040-4039(00)78589-3

65. Kojima, M.; Toda, F.; Hattori, K. J. Chem. Soc., Perkin Trans. 1 1981, 1647. http://dx.doi.org/10.1039/p19810001647

66. Yoon, C-.J.; Ikeda, H.; Kojin, R.; Ikeda, T.; Toda, F. J. Chem. Soc., Chem. Commun. 1986, 1080.

http://dx.doi.org/10.1039/c39860001080

67. Schwall, H.; Regitz, M. Chem. Ber. 1968, 101, 2633.

http://dx.doi.org/10.1002/cber.19681010805

68. Schönberg, A.; Singer, E .Tetrahedron Lett. 1969, 10, 4571. http://dx.doi.org/10.1016/S0040-4039(01)88753-0

69. Schönberg, A.; Singer, E. Chem. Ber. 1970, 103, 3871. http://dx.doi.org/10.1002/cber.19701031218

70. Ried, W.; Vogl, M. Chem. Ber. 1982, 115, 403. http://dx.doi.org/10.1002/cber.19821150202

71. Campbell, J. B.; Lavagnino, E. R.; Ryan, C. W. Org. Prep. Proced. Int. 1991, 23, 660. http://dx.doi.org/10.1080/00304949109457922

72. Peet, N. P.; Huber, E. W.; Huffman, J. C. J. Heterocycl. Chem. 1995, 32, 33. http://dx.doi.org/10.1002/jhet.5570320106

73. Chakrabarty, M.; Mukherji, A.; Arima, S.; Harigaya, Y.; Pilet, G. Monatsh. Chem. 2009, 140, 189.

http://dx.doi.org/10.1007/s00706-008-0066-6

74. Kundu, S. K.; Patra, A.; Pramanik, A. Indian J. Chem. 2004, 43B, 604.

75. Yamamoto, Y.; Takagishi, H.; Itoh, K. J. Am. Chem. Soc. 2002, 124, 6844. http://dx.doi.org/10.1021/ja0264100

76. Song, H. N.; Seong, M. R.; Son, J. S.; Kim, J. N. Synth. Commun. 1998, 28, 1865. http://dx.doi.org/10.1080/00397919808007017

77. Song, H. N.; Lee, H. J.; Kim, H. R.; Ryu, E. K.; Kim, J. N. Synth. Commun. 1999, 29, 3303. http://dx.doi.org/10.1080/00397919908085958

78. Song, H. N.; Lee, H. J.; Kim, T. Y.; Kim, J. N. Bull. Korean Chem. Soc. 1999, 20, 1229.

79. Song, H. N.; Lee, H. J.; Seong, M. R.; Jung, K. S.; Kim, J. N. Synth. Commun. 2000, 30, 1057.

http://dx.doi.org/10.1080/00397910008087123

80. Kundu, S. K.; Das, S.; Pramanik, A. Indian J. Chem. 2004, 43B, 2212.

81. Hashimoto, S.; Sakuma, N.; Wakabayashi, H.; Miyamae, H.; Kobayashi, K. Chem. Lett. 2008, 37, 696 .

http://dx.doi.org/10.1246/cl.2008.696 
82. Ahadi, S.; Moafi, L.; Feiz, A.; Bazgir, A. Tetrahedron 2011, 67, 3954.

http://dx.doi.org/10.1016/j.tet.2011.02.054

83. Sahu, K.; Banerjee, M.; Ghosh, S.; Maity, A.; Mondal, S.; Paira, R.; Hazra, A.; Karmakar, S.; Samanta, A.; Mondal, N. Med. Chem. Res. 2013, 22, 2023.

http://dx.doi.org/10.1007/s00044-012-0202-z

84. Schmitt, G.; Dinh An, N.; Poupelin, J.-P.; Bernard Laude, J. V. Synthesis 1984, 1984, 758. http://dx.doi.org/10.1055/s-1984-30960

85. Karimi, A. R.; Rajabi-Khorrami, A.; Alimohammadi, Z.; Mohammadi, A. A.; Mohammadizadeh, M. R. Monatsh. Chem. 2006, 137, 1079.

http://dx.doi.org/10.1007/s00706-006-0501-5

86. Kazemizadeh, A. R.; Ramazani, A. Arkivoc 2008, 15, 159.

http://dx.doi.org/10.3998/ark.5550190.0009.f15

87. Kazemizadeh, A. R.; Ramazani, A. J. Braz. Chem. Soc. 2009, 20, 309.

http://dx.doi.org/10.1590/S0103-50532009000200016

88. Karimi, A. R.; Behzadi, F.; Faghihi, K. Mol. Divers. 2009, 13, 379.

http://dx.doi.org/10.1007/s11030-009-9119-y

89. Shoaei, S. M.; Kazemizadeh, A. R.; Ramazani, A. Chinese J. Struct. Chem. 2011, 30, 568.

90. Kazemizadeh, A. R.; Ramazani, A. Asian J. Chem. 2011, 23, 4613.

91. Kazemizadeh, A. R.; Ramazani, A. Asian J. Chem. 2012, 24, 3383.

92. Yahyaei, H.; Kazemizadeh, A. R.; Ramazani, A. Chinese J. Struct. Chem. 2012, 31, 1346.

93. Ramazani, A.; Bodaghi, A. Tetrahedron Lett. 2000, 41, 567.

http://dx.doi.org/10.1016/S0040-4039(99)02066-3

94. Abd El-Rahman, M. M.; Boulos, L. S. Molecules 2002, 7, 81.

http://dx.doi.org/10.3390/70100081

95. Ramazani, A.; Noshiranzadeh, N. Phosphorus, Sulfur, Silicon Relat. Elem. 2003, 178, 1321. http://dx.doi.org/10.1080/10426500390200611

96. Ramazani, A.; Noshiranzadeh, N.; Mohammadi, B. Phosphorus, Sulfur, Silicon Relat. Elem. 2003, 178, 761 .

http://dx.doi.org/10.1080/10426500390198101

97. Ramazani, A. Phosphorus, Sulfur, Silicon Relat. Elem. 2003, 178, 1839. http://dx.doi.org/10.1080/10426500390221519

98. Ramazani, A.; Bodaghi, A. Phosphorus, Sulfur, Silicon Relat. Elem. 2004, 179, 1615. http://dx.doi.org/10.1080/10426500490466166

99. Ramazani, A.; Ahmadi, E.; Noshiranzadeh, N. Phosphorus, Sulfur, Silicon Relat. Elem. 2005, 180, 2285.

http://dx.doi.org/10.1080/104265090920912

100. Ramazani, A.; Kazemizadeh, A. R.; Ahmadi, E. Phosphorus, Sulfur, Silicon Relat. Elem. 2005, $180,1781$.

http://dx.doi.org/10.1080/104265090888405

101. Ramazani, A.; Kazemizadeh, A. R.; Ahmadi, E.; Rahnema, M. Asian J. Chem. 2006, 18, 701. 
102. Ramazani, A.; Azizian, A.; Bandpey, M.; Noshiranzadeh, N. Phosphorus, Sulfur, Silicon Relat. Elem. 2006, 181, 2731. http://dx.doi.org/10.1080/10426500600864437

103. Salmanpour, S.; Ahmadi, E.; Khosravi, N.; Ramazani, A. Asian J. Chem. 2007, 19, 1567.

104. Pakravan, P.; Ramazani, A.; Noshiranzadeh, N.; Sedrpoushan, A. Phosphorus, Sulfur, Silicon Relat. Elem. 2007, 182, 545. http://dx.doi.org/10.1080/10426500601013257

105. Ramazani, A. Asian J. Chem. 2007, 19, 1584.

106. Anary-Abbasinejad, M.; Mazraeh-Seffid, M.; Poorhassan, E.; Hassanabadi, A.; Rastegari, F. Arkivoc 2008, 17, 265. http://dx.doi.org/10.3998/ark.5550190.0009.h25

107. Deb, I.; Dadwal, M.; Mobin, S. M.; Namboothiri, I. N. N. Org. Lett. 2006, 8, 1201. http://dx.doi.org/10.1021/o10600411

108. Deb, I.; Shanbhag, P.; Mobin, S. M.; Namboothiri, I. N. N. Eur. J. Org. Chem. 2009, 2009, 4091. http://dx.doi.org/10.1002/ejoc.200900475

109. Kim, S. H.; Kim, S. H.; Lim, C. H.; Kim, J. N. Bull. Korean Chem. Soc. 2012, 33, 2023. http://dx.doi.org/10.5012/bkcs.2012.33.6.2023

110. Khalafi-Nezhad, A.; Mohammadi, S. Synthesis 2012, 44, 1725. http://dx.doi.org/10.1055/s-0031-1290773

111. Li, X.; Yang, L.; Peng, C.; Xie, X.; Leng, H.-J.; Wang, B.; Tang, Z.-W.; He, G.; Ouyang, L.; Huang, W.; Han, B. Chem. Commun. 2013, 49, 8692.

http://dx.doi.org/10.1039/c3cc44004d

112. Ried, W.; Freitag, D. Chem. Ber. 1966, 99, 2675. http://dx.doi.org/10.1002/cber.19660990837

113. Ried, W.; Freitag, D. Chem. Ber. 1968, 101, 756. http://dx.doi.org/10.1002/cber.19681010248

114. Ried, W.; Wagner, R. Liebigs Ann. Chem. 1970, 741, 181. http://dx.doi.org/10.1002/jlac.19707410122

115. Eister, B.; El-Chahawi, M. A. Chem. Ber. 1970, 103, 173. http://dx.doi.org/10.1002/cber.19701030124

116. Linden, A.; Meyer, M.; Mohler, P.; Rippert, A. J.; Hansen, H.-J. Helv. Chim. Acta 1999, 82, 2274. http://dx.doi.org/10.1002/(sici)1522-2675(19991215)82:12<2274::aid-hlca2274>3.0.co;2-9

117. Campbell, L. A.; Morrison, B. J.; Musgrave, O. C. J. Chem. Res. 2002, 2002, 638. http://dx.doi.org/10.3184/030823402103171096

118. Kiyohara, S.; Ishizuka, K.; Wakabayashi, H.; Miyamae, H.; Kanazumi, M.; Kato, T.; Kobayashi, K. Tetrahedron Lett. 2007, 48, 6877. http://dx.doi.org/10.1016/j.tetlet.2007.07.175

119. Yao, W.; Liu, Q.; Shi, Y.; Tang, J. Heterocycles 2012, 85, 1077. http://dx.doi.org/10.3987/COM-12-12427 
120. Rubin, M. B. Chem. Rev. 1975, 75, 177. http://dx.doi.org/10.1021/cr60294a002

121. Rubin, M. B.; Gleiter, R. Chem. Rev. 2000, 100, 1121. http://dx.doi.org/10.1021/cr960079j

122. Retinger, J. M. J. Am. Chem. Soc. 1917, 39, 1059. http://dx.doi.org/10.1021/ja02250a024

123. MacFadyen, D. A.; Fowler, N. J. Biol. Chem. 1950, 186, 13.

124. Bottom, C. B.; Hanna, S. S.; Siehr, D. J. Biochem. Educ. 1978, 6, 4. http://dx.doi.org/10.1016/0307-4412(78)90153-x

125. Petrovskaia ,O.; Taylor, B. M.; Hauze, D. B.; Carroll, P. J.; Joullié, M. M. J. Org. Chem. 2001, 66, 7666.

http://dx.doi.org/10.1021/jo0105179

126. Schertz, T. D.; Reiter, R. C.; Stevenson, C. D. J. Org. Chem. 2001, 66, 7596. http://dx.doi.org/10.1021/jo0102720

127. Friedman, M. J. Agric. Food Chem. 2004, 52, 385. http://dx.doi.org/10.1021/jf030490p

128. Jelly, R.; Patton, E. L. T.; Lennard, C.; Lewis, S. W.; Lim, K. F. Anal. Chim. Acta 2009, 652, 128.

http://dx.doi.org/10.1016/j.aca.2009.06.023

129. Spedding, G. J. Am. Soc. Brew. Chem. 2013, 71, 83.

http://dx.doi.org/10.1094/ASBCJ-2013-0411-01

130. Kametani, T.; Hibino, S.; Takano, S. J. Chem. Soc., Perkin Trans. 1 1972, 391. http://dx.doi.org/10.1039/p19720000391

131. Becker, H.-D.; Russell, G. A. J. Org. Chem. 1963, 28, 1896. http://dx.doi.org/10.1021/jo01042a502

132. Wood, L. L. U.S. Patent 3419616, 1968; Chem. Abstr. 1968, 70, 67996.

133. Wasserman, H. H.; Pickett, J. E. J. Am. Chem. Soc. 1982, 104, 4695. http://dx.doi.org/10.1021/ja00381a040

134. Wasserman, H. H.; Pickett, J. E. Tetrahedron 1985, 41, 2155. http://dx.doi.org/10.1016/S0040-4020(01)96587-1

135. Tatsugi, J.; Izawa, Y. J. Chem. Res. (M) 1988, 2747.

136. Teeters, W. O.; Shriner, R. L. J. Am. Chem. Soc. 1933, 55, 3026. http://dx.doi.org/10.1021/ja01334a072

137. Dominguez, X. A. J. Chem. Educ. 1953, 30, 624. http://dx.doi.org/10.1021/ed030p624

138. Mahran, M. R.; Abdo, W. M.; Sidky, M. M.; Wamhoff, H. Synthesis 1987, 1987, 506. http://dx.doi.org/10.1055/s-1987-27986

139. Wanaǵ, G.; Lode, A. Chem. Ber. 1938, 71, 1267. http://dx.doi.org/10.1002/cber.19380710625

140. Prakash, O.; Sharma, P. K.; Saini, N. Indian J. Chem. 1995, 34, 632. 
141. Lennard, C. J.; Margot, P. A.; Stoilovic, M.; Warrener, R. N. J. Forensic Sci. Soc. 1986, 26, 323.

http://dx.doi.org/10.1016/S0015-7368(86)72510-3

142. Lennard, C. J.; Margot, P. A.; Stoilovic, M.; Warrener, R. N. J. Forensic Sci. Soc. 1988, 28 , 3. http://dx.doi.org/10.1016/S0015-7368(88)72799-1

143. Zenkova, E. A.; Degterev, E. V. Pharm. Chem. J. 2000, 34, 135. http://dx.doi.org/1/0.1007bf02524583

144. Heffner, R.; Safaryn, J. E.; Joullié, M. M. Tetrahedron Lett. 1987, 28, 6539. http://dx.doi.org/10.1016/S0040-4039(00)96907-7

145. Heffner, R. J.; Joullié, M. M. Synth. Commun. 1991, 21, 1055. http://dx.doi.org/10.1080/00397919108.019795

146. Hallman, J. L.; Bartsch, R. A. J. Org. Chem. 1991, 56, 6243. http://dx.doi.org/10.1021/jo00021a055

147. Heffner, R. J.; Joullié, M. M. Synth. Commun. 1991, 21, 2231. http://dx.doi.org/10.1080/00397919108055457

148. Boichard, J. F. P. U.S. Patent 3349132, 1967; Chem. Abstr. 1967, 60, 68083.

149. Jones, R. A. Ed., In Pyrroles, Part II; Wiley: New York, 1992. http://dx.doi.org/10.1002/9780470187340

150. Dyatkina, N. B.; Roberts, C. D.; Keicher, J. D.; Dai, Y.; Nadherny, J. P.; Zhang, W.; Schmitz, U.; Kongpachith, A.; Fung, K.; Novikov, A. A.; Lou, L.; Velligan, M.; Khorlin, A. A.; Chen ,M. S. J. Med. Chem. 2002, 45, 805. http://dx.doi.org/10.1021/jm010375a

151. Harrak, Y.; Rosell, G.; Daidone, G.; Plescia, S.; Schillaci, D.; Pujol, M. D. Bioorg. Med. Chem. 2007, 15, 4876. http://dx.doi.org/10.1016/j.bmc.2007.04.050

152. Nagamura, S.; Kobayashi, E.; Gomi, K.; Saito, H. Bioorg. Med. Chem. 1996, 4, 1379. http://dx.doi.org/10.1016/0968-0896(96)00132-0

153. Artico, M.; Silvestri, R.; Stefancich, G.; Massa, S.; Pagnozzi, E.; Musu, D.; Scintu, F.; Pinna, E.; Tinti, E.; La Colla, P. Arch. Pharm. 1995, 328, 223. http://dx.doi.org/10.1002/ardp.19953280304

154. Dickinson, L. A.; Trauger, J. W.; Baird, E. E.; Ghazal, P.; Dervan, P. B.; Gottesfeld, J. M. Biochemistry 1999, 38, 10801. http://dx.doi.org/10.1021/bi9912847

155. Sun, L.; Liang, C.; Shirazian, S.; Zhou, Y.; Miller, T.; Cui, J.; Fukuda, J. Y.; Chu, J.-Y.; Nematalla, A.; Wang, X.; Chen, H.; Sistla, A.; Luu, T. C.; Tang, F.; Wei, J.; Tang, C. J. Med. Chem. 2003, 46, 1116. http://dx.doi.org/10.1021/jm0204183

156. Kreipl, A. T.; Reid, C ;.Steglich, W. Org. Lett. 2002, 4, 3287. http://dx.doi.org/10.1021/o1026555b 
157. Weigele, M.; Blount, J. F.; Tengi, J. P.; Czajkowski, R. C.; Leimgruber, W. J. Am. Chem. Soc. 1972, 94, 4052.

http://dx.doi.org/10.1021/ja00766a088

158. Shapiro, R.; Chatterjie, N. J. Org. Chem. 1970, 35, 447.

http://dx.doi.org/10.1021/jo00827a034

159. Black, D. St. C.; Bowyer, M. C.; Condie, G. C.; Craig, D. C.; Kumar, N. Tetrahedron 1994, 50, 10983.

http://dx.doi.org/10.1016/S0040-4020(01)85709-4

160. Bullington, J. L.; Dodd, J. H. J. Org. Chem. 1993, 58, 4833.

http://dx.doi.org/10.1021/jo00070a017

161. Azizian, J.; Karimi, A. R.; Arefrad, H.; Mohammadi, A. A.; Mohammadizadeh, M. R. Mol. Divers. 2003, 6, 223.

http://dx.doi.org/10.1023/B:MODI.0000006779.13561.12

162. Azizian, J.; Hatamjafari, F.; Karimi, A. R.; Shaabanzadeh, M. Synthesis 2006, 765.

http://dx.doi.org/10.1055/s-2006-926327

163. Hatamjafari, F.; Montazeri, N. Turk. J. Chem. 2009, 33, 797.

http://dx.doi.org/10.3906/kim-0810-47

164. Yavari, I.; Seyfi, S.; Nematpour, M.; Hossaini, Z. Helv. Chim. Acta 2010, 93, 1413. http://dx.doi.org/10.1002/hlca.200900408

165. Alizadeh, A.; Zarei, A.; Rezvanian, A. Synthesis 2011, 3, 497.

http://dx.doi.org/10.1055/s-0030-1258383

166. Alizadeh, A.; Rezvanian, A.; Zhu, L .G. J. Org. Chem. 2012, 77, 4385.

http://dx.doi.org/10.1021/jo300457m

167. Rezvanian, A.; Alizadeh, A. Tetrahedron 2012, 68, 10164.

http://dx.doi.org/10.1016/j.tet.2012.09.101

168. Alizadeh, A.; Mokhtari, J. C. R. Chim. 2013, 16, 105.

http://dx.doi.org/1/0.1016j.crci.2012.10.003

169. Rostami-Charati, F.; Hossaini, Z.; Khalilzadeh, M. A.; Jafaryan, H. J. Heterocycl. Chem. 2012, 49, 217. http://dx.doi.org/10.1002/jhet.785

170. Rostami-Charati, F. Chin. Chem. Lett. 2014, 25, 169. http://dx.doi.org/10.1016/j.cclet.2013.09.016

171. Azizian, J.; Sheikholeslami, F.; Hosseini, J.; Mohammadi, M.; Mirza, B. J. Heterocycl. Chem. 2012, 49, 413.

http://dx.doi.org/10.1002/jhet.835

172. Pathak, S.; Kundu, A.; Pramanik, A. Tetrahedron Lett. 2011, 52, 5180.

http://dx.doi.org/10.1016/j.tetlet.2011.07.133

173. Pathak, S.; Debnath, K.; Pramanik, A. Beilstein J. Org. Chem. 2013, 9, 2344.

http://dx.doi.org/10.3762/bjoc.9.269

174. Yan, S.-J.; Chen, Y.-L.; Liu, L.; Tang, Y.-J.; Lin, J. Tetrahedron Lett. 2011, 52, 465. http://dx.doi.org/10.1016/j.tetlet.2010.11.100 
175. Ahadi, S.; Imani Shakibaei, G.; Mirzaei, P.; Bazgir, A. Heterocycles 2008, 75, 2293. http://dx.doi.org/10.3987/COM-08-11391

176. Hemmerling, H.-J.; Merschenz-Quack, A.; Wunderlich, H. Z. Naturforsch. 2004, 59, 1143. http://dx.doi.org/10.1002/chin.200508123

177. Hemmerling, H.-J.; Reiss, G. Synthesis 2009, 985. http://dx.doi.org/10.1055/s-0028-1087983

178. Hundsdörfer, C.; Hemmerling, H.-J.; Götz, C.; Totzke, F.; Bednarski, P.; Le Borgne, M.; Jose, J. Bioorg. Med. Chem. 2012, 20, 2282.

http://dx.doi.org/10.1016/j.bmc.2012.02.017

179. Hundsdörfer, C.; Hemmerling, H.-J.; Hamberger, J.; Le Borgne, M.; Bednarski, P.; Götz, C.; Totzke, F.; Jose, J. Biochem. Biophys. Res. Commun. 2012, 424, 71. http://dx.doi.org/10.1016/j.bbrc.2012.06.068

180. Jiang, B.; Li, Q.-Y.; Tu, S.-J.; Li, G. Org. Lett. 2012, 14, 5210. http://dx.doi.org/10.1021/ol3023038

181. Bazgir, A.; Khanaposhtani, M. M.; Ghahremanzadeh, R.; Soorki, A. A. C. R. Chim. 2009, $12,1287$. http://dx.doi.org/10.1016/j.crci.2009.06.004

182. Mohammadizadeh, M. R.; Bahramzadeh, M.; Taghavi, S. Z. Tetrahedron Lett. 2010, 51, 5807.

http://dx.doi.org/10.1016/j.tetlet.2010.08.113

183. O'Hagan, D. Nat. Prod. Rep. 2000, 17, 435. http://dx.doi.org/10.1039/a707613d

184. Fiaux, H.; Kuntz, D. A.; Hoffman, D.; Janzer, R. C.; Gerber-Lemaire, S.; Rose, D. R.; Juillerat-Jeanneret, L. Bioorg. Med. Chem. 2008, 16, 7337. http://dx.doi.org/10.1016/j.bmc.2008.06.021

185. Raj, A. A.; Raghunathan, R.; SrideviKumari, M. R.; Raman, N. Bioorg. Med. Chem. 2003, $11,407$. http://dx.doi.org/10.1016/S0968-0896(02)00439-X

186. Kim, D.; Wang, L.; Hale, J. J.; Lynch, C. L.; Budhu, R. J.; MacCoss, M.; Mills, S. G.; Malkowitz, L.; Gould, S. L.; DeMartino, J. A.; Springer, M. S.; Hazuda ,D.; Miller, M.; Kessler, J.; Hrin, R. C.; Carver, G.; Carella, A.; Henry, K.; Lineberger, J.; Schleif, W. A.; Emini, E. A. Bioorg. Med. Chem. Lett. 2005, 15, 2129. http://dx.doi.org/10.1016/j.bmcl.2005.02.030

187. Liddell, J. R. Nat. Prod. Rep. 1997, 14, 653. http://dx.doi.org/10.1039/np9971400653

188. Arumugam, N.; Periyasami, G.; Raghunathan, R.; Kamalraj, S.; Muthumary, J. Eur. J. Med. Chem. 2011, 46, 600.

http://dx.doi.org/10.1016/j.ejmech.2010.11.039

189. Niwa, H.; Ogawa, T.; Yamada, K. Tetrahedron Lett. 1989, 30, 4985. http://dx.doi.org/10.1016/S0040-4039(01)80561-X 
190. Matloubi Moghaddam, F.; Khodabakhshi, M. R.; Ghahremannejad, Z.; Koushki Foroushani, B.; Ng, S. W. Tetrahedron Lett. 2013, 54, 2520. http://dx.doi.org/10.1016/j.tetlet.2013.03023.

191. Bhaskar, G.; Arun, Y.; Balachandran, C.; Saikumar, C.; Perumal, P. T. Eur. J. Med. Chem. 2012, 51, 79 . http://dx.doi.org/10.1016/j.ejmech.2012.02.024

192. Poornachandran, M.; Raghunathan, R. Indian J. Chem. 2010, 49, 127.

193. Panja, S. K.; Karmakar, P.; Chakraborty, J.; Ghosh, T.; Bandyopadhyay, C. Tetrahedron Lett. 2008, 49, 4397. http://dx.doi.org/10.1016/j.tetlet.2008.05.018

194. Kathiravan, S.; Raghunathan, R. Indian J. Chem. 2008, 47, 1117.

195. Chee Wei, A.; Ashraf Ali, M.; Keng Yoon ,Y.; Ismail, R.; Soo Choon, T.; Suresh Kumar, R.; Arumugam, N.; Almansour, A. I.; Osman, H. Bioorg. Med. Chem. Lett. 2012, 22, 4930. http://dx.doi.org/10.1016/j.bmcl.2012.06.047

196. Babu, A. R. S.; Raghunathan, R. Tetrahedron Lett. 2008, 49, 4618. http//:dx.doi.org/10.1016/j.tetlet.2008.05.089

197. Poornachandran, M.; Muruganantham, R.; Raghunathan, R. Synth. Commun. 2006, 36, 141. http://dx.doi.org/10.1080/00397910500333241

198. Poornachandran, M.; Raghunathan, R. Synth. Commun. 2007, 37, 2507. http//:dx.doi.org/10.1080/00397910701462575

199. Chen, G.; Wu, Y.; Gu, X. Heterocycl. Commun. 2011, 17, 161. http://dx.doi.org/10.1515/HC.2011.023

200. Chen, G.; Zhang, J.; Wu, Y. Res. Chem. Intermed. 2012, 38, 413. http://dx.doi.org/10.1007/s11164-011-0357-0

201. Chen, G.; Gu, X.; Ma, C. Heterocycl. Commun. 2012, 18, 47. http://dx.doi.org/10.1515/hc-2011-0053

202. Lakshmi, N. V.; Thirumurugan, P.; Jayakumar, C.; Perumal, P. T. Synlett 2010, 955. http://dx.doi.org/10.1055/s-0029-1219550

203. Jayashankaran ,J.; Manian, R. D. R. S.; Raghunathan, R. Synthesis 2006, 1028. http://dx.doi.org/10.1055/s-2006-926347

204. Sridhar, G.; Gunasundari, T.; Raghunathan, R. Tetrahedron Lett. 2007, 48, 319. http://dx.doi.org/10.1016/j.tetlet.2006.11.002

205. Lakshmi, N. V.; Arun, Y.; Perumal, P. T. Tetrahedron Lett. 2011, 52, 3437. http://dx.doi.org/10.1016/j.tetlet.2011.04.093

206. Manian, R. D. R. S.; Jayashankaran, J.; Raghunathan, R. Tetrahedron 2006, 62, 12357. http://dx.doi.org/10.1016/j.tet.2006.09.105

207. Chandralekha, E.; Thangamani, A.; Valliappan, R. Res. Chem. Intermed. 2013, 39, 961. http://dx.doi.org/10.1007/s11164-012-0608-8

208. Suresh Kumar, R.; Osman, H.; Perumal, S.; Menendez, J. C.; Ashraf Ali, M.; Ismail, R.; Soo Choon, T. Tetrahedron 2011, 67, 3132. http://dx.doi.org/10.1016/j.tet.2011.02.058 
209. Suresh Kumar, R.; Ashraf Ali, M.; Osman, H.; Ismail, R.; Soo Choon, T.; Keng Yoon, Y.; Chee Wei, A.; Pandian, S.; Manogaran, E. Bioorg. Med. Chem. Lett. 2011, 21, 3997. http://dx.doi.org/10.1016/j.bmcl2011.05.003.

210. Dandia, A.; Jain, A. K.; Sharma, S. Tetrahedron Lett. 2012, 53, 5859.

http://dx.doi.org/10.1016/j.tetlet.2012.08.060

211. Rajesh, S. M.; Bala, B. D.; Perumal, S. Tetrahedron Lett. 2012, 53, 5367. http://dx.doi.org/10.1016/j.tetlet.2012.07.078

212. Suresh Babu, A. R.; Raghunathan, R.; Satiskumar, B. K. Tetrahedron Lett. 2009, 50, 2818. http://dx.doi.org/10.1016/j.tetlet.2009.03.175

213. Suresh Babu, A. R.; Gavaskar, D.; Raghunathan, R. Tetrahedron Lett. 2012, 53, 6676. http://dx.doi.org/10.1016/j.tetlet.2012.09.104

214. Kathiravan, S.; Raghunathan, R. Tetrahedron Lett. 2009, 50, 6116. http://dx.doi.org/10.1016/j.tetlet.2009.08.047

215. Kathiravan, S.; Raghunathan, R.; Suresh, G.; Siva, G. Med. Chem. Res. 2012, 21, 3170. http://dx.doi.org/10.1007/s00044-011-9852-5

216. Jayashankaran, J.; Durga, R.; Manian, R. S.; Raghunathan, R. Synth. Commun. 2006, 36, 979. http://dx.doi.org/10.1080/00397910500464889

217. Ramesh, E.; Kathiresan, M.; Raghunathan, R. Tetrahedron Lett. 2007, 48, 1835. http://dx.doi.org/10.1016/j.tetlet.2007.01.008

218. Jayashankaran, J.; Manian, R. D. R. S.; Sivaguru, M.; Raghunathan, R. Tetrahedron Lett. 2006, 47, 5535.

http://dx.doi.org/10.1016/j.tetlet.2006.05.149

219. Shanmugam, P.; Madhavan, S.; Viswambharan, B.; Vaithiyanathan, V. Indian J. Chem. 2008, 47B, 1113.

220. Manian, R. D. R. S.; Jayashankaran, J.; Kumar, S. S.; Raghunathan, R. Tetrahedron Lett. 2006, 47, 829 .

http://dx.doi.org/10.1016/j.tetlet.2005.11.089

221. Rajkumar, V.; Aslam, N. A.; Reddy, C.; Babu, S. A. Synlett 2012, 2012, 549. http://dx.doi.org/10.1055/s-0031-1290342

222. Gul, M.; Kulu, I.; Gunkara, O. T.; Ocal, N. Acta Chim. Slov. 2013, 60, 87.

223. Poornachandran, M.; Jayagobi, M.; Raghunathan, R. Synth. Commun. 2010, 40, 551. http://dx.doi.org/10.1080/00397910903004373

224. Johnson, A. W.; McCaldin, D. J. J. Chem. Soc. 1958, 817. http://dx.doi.org/10.1039/jr9580000817

225. Aly, M. F.; Ardill, H.; Grigg, R.; Leong-Ling, S.; Rajviroongit, S.; Surendrakumar, S. Tetrahedron Lett. 1987, 28, 6077. http://dx.doi.org/10.1016/S0040-4039(00)96868-0

226. Johnson, A. W.; McCaldin, D. J. J. Chem. Soc. 1960, 3412. http://dx.doi.org/10.1039/JR9600003412 
227. Moemeni, M.; Arvinnezhad, H.; Samadi, S.; Tajbakhsh, M.; Jadidi, K.; Khavasi, H. R .J. Heterocycl. Chem. 2012, 49, 190. http://dx.doi.org/10.1002/jhet.685

228. Mohammadizadeh, M. R.; Firoozi, N. Bull. Korean Chem. Soc. 2009, 30, 1877. http://dx.doi.org/10.5012/bkcs.2009.30.8.1877

229. Grigg, R.; Surendrakumar, S.; Thianpatanagul, S.; Vipond, D. J. Chem. Soc., Perkin Trans. 1 1988, 2693. http://dx.doi.org/10.1039/p19880002693

230. Coulter, T.; Grigg, R.; Malone, J. F.; Sridharan, V. Tetrahedron Lett. 1991, 32, 5417. http://dx.doi.org/10.1016/S0040-4039(00)92401-8

231. Azizian, J.; Karimi, A. R.; Mohammadi, A. A.; Mohammadizadeh, M. R. Synthesis 2004, 2263. http://dx.doi.org/10.1055/s-2004-831186

232. Alizadeh Karsalary, A.; Mohammadizadeh, M. R.; Hasaninejad, A. R.; Mohammadi, A. A.; Karimi, A. R. J. Iran. Chem. Soc. 2010, 7, 45. http://dx.doi.org/10.1007/bf03245858

233. Grigg, R.; Malone, J. F.; Mongkolaussavaratana, T.; Thianpatanagul, S. Tetrahedron 1989, $45,3849$.

http://dx.doi.org/10.1016/S0040-4020(01)89244-9

234. Yu, X. Y.; Finn, J.; Hill, J. M.; Wang, Z. G.; Keith, D.; Silverman, J.; Oliver, N. Bioorg. Med. Chem. Lett. 2004, 14, 1339.

http://dx.doi.org/10.1016/j.bmcl.2003.11.081

235. Grigg, R.; Thianpatanagul, S. J. Chem. Soc., Chem. Commun. 1984, 180. http://dx.doi.org/10.1039/c39840000180

236. Ardill, H.; Dorrity, M. J. R.; Grigg, R.; Leon-Ling, M.-S.; Malone, J. F.; Sridharan, V.; Thianpatanagul, S. Tetrahedron 1990, 46, 6433. http://dx.doi.org/10.1016/S0040-4020(01)96013-2

237. Grigg, R.; William, P. A. Tetrahedron 1988, 44, 1523. http://dx.doi.org/10.1016/S0040-4020(01)85931-7

238. Suresh Babu, A. R.; Raghunathan, R. Tetrahedron Lett. 2007, 48, 6809. http://dx.doi.org/10.1016/j.tetlet.2007.07.085

239. Suresh Babu, A. R.; Raghunathan, R. Synth. Commun. 2008, 38, 1433. http://dx.doi.org/10.1080/00397910801914327

240. Velikorodov, A. V.; Poddubnyi, O. Y.; Krivosheev, O. O.; Titova, O. L. Russ. J. Org. Chem. 2011, 47, 402.

http://dx.doi.org/10.1134/s1070428011030122

241. Suresh Babu, A. R.; Raghunathan, R. Tetrahedron Lett. 2006, 47, 9221. http://dx.doi.org/10.101/6j.tetlet.2006.10.139

242. Suresh Babu, A. R.; Raghunathan, R. Synth. Commun. 2008, 39, 347. http://dx.doi.org/10.1080/00397910802374091 
243. Periyasami, G.; Raghunathan, R.; Surendiran, G.; Mathivanan, N. Eur. J. Med. Chem. 2009, 44, 959.

http://dx.doi.org/10.1016/j.ejmech.2008.07.009

244. Crooks, P. A.; DeSimone, F.; Ramundo, E. J. Heterocycl. Chem. 1982, 19, 1433. http://dx.doi.org/10.1002/jhet.5570190635

245. Li, M.; Gong, F.-M.; Wen, L.-R.; Li, Z.-R. Eur. J. Org. Chem. 2011, 2011, 3482. http://dx.doi.org/10.1002/ejoc.201100297

246. Pilipecz, M. V.; Mucsi, Z.; Nemes, P.; Scheiber, P. Heterocycles 2007, 71, 1919. http://dx.doi.org/10.3987/COM-07-11073

247. Lobo, G.; Zuleta, E.; Charris, K.; Capparelli, M. V.; Briceno, A.; Angel, J.; Charris, J .J. Chem. Res. 2011, 35, 222. http://dx.doi.org/10.3184/174751911x13015834294266

248. Sarrafi, Y.; Hamzehlouian, M.; Alimohammadi, K.; Khavasi, H. R. Tetrahedron Lett. 2010, $51,4734$.

http://dx.doi.org/10.1016/j.tetlet.2010.07.018

249. Palaska, E.; Aytemir, M.; Uzbay, İ. T.; Erol, D. Eur. J. Med. Chem. 2001, 36, 539. http://dx.doi.org/10.1016/S0223-5234(01)01243-0

250. Azarifar, D.; Shaebanzadeh, M. Molecules 2002, 7, 885. http://dx.doi.org/10.3390/71200885

251. Shaharyar, M.; Siddiqui, A. A.; Ali, M .A.; Sriram, D.; Yogeeswari, P. Bioorg. Med. Chem. Lett. 2006, 16, 3947. http://dx.doi.org/10.1016/j.bmcl.2006.05.024

252. Yavari, I.; Seyfi, S.; Skoulika, S. Helv. Chim. Acta 2012, 95, 1581. http://dx.doi.org/10.1002/hlca.201200053

253. Alizadeh, A.; Zarei, A.; Rezvanian, A. Helv. Chim. Acta 2012, 95, 278. http://dx.doi.org/10.1002/hlca.201100317

254. Lombardino, J. G.; Wiseman, E. H. J. Med. Chem. 1974, 17, 1182. http://dx.doi.org/10.1021/jm00257a011

255. Tafi, A.; Costi, R.; Botta, M.; Di Santo, R.; Corelli, F.; Massa, S.; Ciacci, A.; Manetti, F.; Artico, M. J. Med. Chem. 2002, 45, 2720.

http://dx.doi.org/10.1021/jm011087h

256. Chuck Dunbar, D.; Rimoldi, J. M.; Clark, A. M.; Kelly, M.; Hamann, M. T. Tetrahedron 2000, 56, 8795 .

http://dx.doi.org/10/1016.S0040-4020(00)00821-8

257. Silvestri, R.; Artico, M.; La Regina, G.; Di Pasquali, A.; De Martino, G.; D'Auria, F. D.; Nencioni, L.; Palamara, A. T. J. Med. Chem. 2004, 47, 3924. http://dx.doi.org/10.1021/jm049856v

258. Caterina, M. C.; Perillo, I .A.; Boiani, L.; Pezaroglo, H.; Cerecetto, H.; González, M.; Salerno, A. Bioorg. Med. Chem. 2008, 16, 2226.

http://dx.doi.org/10.1016/j.bmc.2007.11.077 
259. da Silva Guerra, A. S. H.; do Nascimento Malta, D. J.; Morais Laranjeira, L. P.; Souza Maia, M. B.; Cavalcanti Colaço, N.; do Carmo Alves de Lima, M.; Galdino, S. L.; da Rocha Pitta, I.; Gonçalves-Silva, T. Int. Immunopharmacol. 2011, 11, 1816.

http://dx.doi.org/10.1016/j.intimp.2011.07.010

260. Thirupathi Reddy, Y.; Narsimha Reddy, P.; Koduru, S.; Damodaran, C.; Crooks, P. A. Bioorg. Med. Chem. 2010, 18, 3570. http://dx.doi.org/10.1016/j.bmc.2010.03.054

261. Van Slyke, D. D.; Dillon, R. T.; MacFadyen, D. A.; Hamilton, P. B. J. Biol. Chem. 1941, $141,627$.

262. Van Slyke, D. D.; Hamilton, P. B. J. Biol. Chem. 1943, 150, 471.

263. Lengyel, I.; Patel, H. J.; Stephani, R. A. Heterocycles 2007, 73, 349. http://dx.doi.org/10.3987/COM-07-S(U)9

264. Sadarangani, I. R.; Bhatia, S.; Amarante, D.; Lengyel, I.; Stephani, R. A. Bioorg. Med. Chem. Lett. 2012, 22, 2507. http://dx.doi.org/10.1016/j.bmcl.2012.02.005

265. Patel, H. J.; Sarra, J.; Caruso, F.; Rossi, M.; Doshi, U.; Stephani, R. A. Bioorg. Med. Chem. Lett. 2006, 16, 4644. http://dx.doi.org/10.1016/j.bmcl.2006.05.102

266. Schönberg, A.; Singer, E.; Eschenhof, B.; Hoyer, G.-A. Chem. Ber. 1978, 111, 3058. http://dx.doi.org/10.1002/cber.19781110906

267. Alizadeh, A.; Zarei, A.; Rezvanian, A. Helv. Chim. Acta 2011, 94, 1802. http://dx.doi.org/10.1002/hlca.201100062

268. Uma Devi, T.; Priya, S.; Selvanayagam, S.; Ravikumar, K.; Anitha, K. Spectrochim. Acta A 2012, 97, 1063. http://dx.doi.org/10.1016/j.saa.2012.07.118

269. Seyfi, S.; Hossaini, Z.; Rostami-Charati, F. Comb. Chem. High Throughput Screen. 2013, 16, 652.

http://dx.doi.org/10.2174/13862073113169990005

270. Azizian, J.; Karimi, A. R.; Soleimani, E.; Mohammadi, A. A.; Mohammadizadeh, M. R. Heteroat. Chem. 2006, 17, 277.

http://dx.doi.org/10.1002/hc.20202

271. Das, S.; Fröhlich, R.; Pramanik, A. Org. Lett. 2006, 8, 4263. http://dx.doi.org/10.1/021o1061520n

272. Chatterjie, N.; Stephani, R. A.; Strom, C. H. J. Pharm. Sci. 1980, 69, 1431. http://dx.doi.org/10.1002/jps.2600691221

273. Ghalib, R. M.; Hashim, R.; Alshahateet, S. F.; Mehdi, S. H.; Sulaiman, O.; Murugaiyah, V.; Aruldass, C. A. J. Mol. Struct. 2011, 1005, 152.

http://dx.doi.org/10.1016/i.molstruc.2011.08.042

274. Ghalib, R. M.; Hashim, R.; Alshahateet, S. F.; Mehdi, S. H.; Sulaiman, O.; Chan, K.-L.; Murugaiyah, V.; Jawad, A. J. Chem. Crystallogr. 2012, 42, 783. http://dx.doi.org/10/1007.s10870-012-0288-7 
275. Wamhoff, H.; Korte, F. Synthesis 1972, 151.

http://dx.doi.org/10.1055/s-1972-21844

276. Scott, R. W.; Mazzetti, C.; Simpson, T. J.; Willis, C. L. Chem. Commun. 2012, 48, 2639. http://dx.doi.org/10.1039/c2cc17721h

277. Bowden, K.; Rumpal, S. J. Chem. Soc., Perkin Trans. 2 1997, 983. http://dx.doi.org/10.1039/a606312h

278. Kapoor, M.; Dhawan, S. N.; Mor, S.; Gupta, S. C. J. Chem. Res. 2008, 2008, 386. http://dx.doi.org/10.3184/030823408785702418

279. Gill, G. B.; Idris, M .S. H.; Kirollos, K. S. J. Chem. Soc., Perkin Trans. 1 1992, 2355. http://dx.doi.org/10.1039/p19920002355

280. Tatsugi, J.; Hara, T.; Izawa, Y. Chem. Lett. 1997, 26, 177. http://dx.doi.org/10.1246/cl.1997.177

281. Kleinman, M. H.; Telo, J. P.; Vieira, A .J. S. C.; Bohne, C.; Netto-Ferreira, J. C. Photochem. Photobiol. 2003, 77, 10. http://dx.doi.org/10.1562/0031-8655(2003)077<0010:TSON>2.0.CO;2

282. Matsuura, T.; Sugae, R.; Nakashima, R.; Omura, K. Tetrahedron 1968, 24, 6149. http://dx.doi.org/10.1016/S.1-96347(01)4020-0040

283. Otsuji, Y.; Wake, S.; Imoto, E. Tetrahedron 1970, 26, 4139. http://dx.doi.org/10.1016/S0040-4020(01)93056-X

284. Itoh, T.; Tatsugi, J.; Tomioka, H. Bull. Chem. Soc. Jpn. 2009, 82, 475. http://dx.doi.org/10.1246/bcsj.82.475

285. Tobisu, M.; Chatani, N.; Asaumi, T.; Amako, K.; Ie, Y.; Fukumoto, Y.; Murai, S. J. Am. Chem. Soc. 2000, 122, 12663.

http://dx.doi.org/10.1021/ja003018i

286. Park, B. R.; Kim, S. H.; Kim, Y. M.; Kim, J. N. Tetrahedron Lett. 2011, 52, 1700. http://dx.doi.org/10.1016/j.tetlet.2011.01.153

287. Maghsoodlou, M. T.; Habibi-Khorassani, S. M.; Moradi, A.; Hazeri, N.; Davodi, A.; Sajadikhah, S. S. Tetrahedron 2011, 67, 8492. http://dx.doi.org/10.1016/j.tet.2011.09.017

288. Panja, S. K.; Maiti, S.; Drew, M. G.B.; Bandyopadhyay, C. J. Chem. Res. 2011, 35, 225. http://dx.doi.org/10.3184/174751911X13015945166625

289. Suzuki, M.; Imai, K.; Wakabayashi, H.; Arita, A.; Johmoto, K.; Uekusa, H.; Kobayashi, K. Tetrahedron 2011, 67, 5500. http://dx.doi.org/10.1016/j.tet.2011.05.032

290. Ghosh, A. K.; Anderson, D. D. Future Med. Chem. 2011, 3, 1181. http://dx.doi.org/10.4155/fmc.11.68

291. Bachan, S.; Tony, K. A.; Kawamura, A.; Montenegro, D.; Joshi, A.; Garg, H.; Mootoo, D. R. Bioorg. Med. Chem. 2013, 21, 6554.

http//:dx.doi.org/10.1016/j.bmc.2013.08.027

292. Wang, W.; Jin, H.; Fuselli, N.; Mansour, T. S. Bioorg. Med. Chem. Lett. 1997, 7, 2567. http://dx.doi.org/10.1016/S0960-894X(97)10048-8 
293. Sugimoto, K.; Tamura, K.; Ohta, N.; Tohda, C.; Toyooka, N.; Nemoto, H.; Matsuya, Y. Bioorg. Med. Chem. Lett. 2012, 22, 449. http://dx.doi.org/10.1016/j.bmcl.2011.10.127

294. Zhang, Y.; Zhong, H.; Wang, T.; Geng, D.; Zhang, M.; Li, K. Eur. J. Med. Chem. 2012, 48, 69. http://dx.doi.org/10.1016/j.ejmech.2011.11.036

295. Yavari, I.; Adib, M.; Sayahi, M. H. Tetrahedron Lett. 2002, 43, 2927. http://dx.doi.org/10.1016/S0040-4039(02)00435-5

296. Yavari, I.; Arab-Salmanabadi, S.; Aminkhani, A. J. Iran. Chem. Soc. 2012, 9, 503. http://dx.doi.org/10.1007/s13738-011-0061-4

297. Safaei-Ghomi, J.; Salimi, F.; Ahmadi, Y.; Ramazani, A.; Zeinali Nasrabadi, F. Chemija 2012, 23, 43.

298. Gein, V. L.; Gein, L. F.; Kuznetsova, E. D.; Aliev, Z. G. Chem. Heterocycl. Compd. 2005, $41,255$. http://dx.doi.org/10.1007/s10593-005-0137-0

299. Gein, V. L.; Gein, L. F.; Sheptukha, M. A.; Voronina, E. V. Pharm. Chem. J. 2005, 39, 537. http://dx.doi.org/10.1007/s11094-006-0016-8

300. Noshiranzadeh, N.; Ramazani, A.; Ślepokura, K.; Lis, T. Synth. Commun. 2008, 38, 1560. http://dx.doi.org/10.1080/00397.910801929374

301. Ramazani, A.; Noshiranzadeh, N.; Ghamkhari, A.; lepokura, K.; Lis, T. Helv. Chim. Acta 2008, 91, 2252. http://dx.doi.org/10.1002/hlca.200890245

302. Salmanpour, S.; Ramazani, A.; Ahmadi, Y. Bull. Chem. Soc. Ethiop. 2012, 26, 153. http//:dx.doi.org/10.4314/bcse.v26i1.18

303. Heinisch, G.; Holzer, W.; Mereiter, K.; Strobl, B.; Zheng, C. Heterocycles 1996, 43, 1665. http://dx.doi.org/10.3987/COM-96-7488

304. Bazin, M.-A.; Bodero, L.; Tomasoni, C.; Rousseau, B.; Roussakis, C.; Marchand, P. Eur. J. Med. Chem. 2013, 69, 823. http://dx.doi.org/10.1016/j.ejmech.2013.09.013

305. Kozikowski, A. P.; Ma, D.; Du, L.; Lewin, N. E.; Blumberg, P. M. Bioorg. Med. Chem. Lett. 1994, 4, 637.

http://dx.doi.org/10.1016/S0960-894X(01)80169-4

306. Hu, Z.-F.; Chen, L.-L.; Qi, J.; Wang, Y.-H.; Zhang, H.; Yu, B.-Y. Fitoterapia 2011, 82, 190. http://dx.doi.org/10.1016/j.fitote.2010.09.002

307. Malpani, Y.; Achary, R.; Kim, S. Y.; Jeong, H. C.; Kim, P.; Han, S. B.; Kim, M.; Lee, C.K.; Kim, J. N.; Jung, Y.-S. Eur. J. Med. Chem. 2013, 62, 534. http://dx.doi.org/10.1016/j.ejmech.2013.01.015

308. Yang, N.; Wang, Q.-H.; Wang, W.-Q.; Wang, J.; Li, F.; Tan, S.-P.; Cheng, M.-S. Bioorg. Med. Chem. Lett. 2012, 22, 53.

http://dx.doi.org/10.1016/j.bmcl.2011.11.078 
309. Ogino, Y.; Ohtake, N.; Nagae, Y.; Matsuda, K.; Ishikawa, M.; Moriya, M.; Kanesaka, M.; Mitobe, Y.; Ito, J.; Kanno, T.; Ishihara, A.; Iwaasa, H.; Ohe, T.; Kanatani, A.; Fukami, T. Bioorg. Med. Chem. Lett. 2008, 18, 4997. http://dx.doi.org/10.1016/j.bmcl2008.08.021.

310. Das, S.; Pramanik, A.; Fröhlich, R.; Patra, A. Tetrahedron 2004, 60, 10197. http://dx.doi.org/10.1016/j.tet.2004.09.004

311. Das, S.; Fröhlich, R.; Pramanik, A. J. Chem. Res. 2005, 2005, 572. http://dx.doi.org/10.3184/030823405774308970

312. Na, J. E.; GowriSankar, S.; Lee, S.; Kim, J. N. Bull. Korean Chem. Soc. 2004, 25, 569. http://dx.doi.org/10.5012/bkcs.2004.25.4.569

313. Mohammadizadeh, M. R.; Firoozi, N.; Aradeh, R. Helv. Chim. Acta 2011, 94, 410. http://dx.doi.org/10.1002/hlca.201000241

314. Na, J. E.; Kim, J. M.; Lee, S.; Kim, J. N. Bull. Korean Chem. Soc. 2003, 24, 1725. http://dx.doi.org/10.5012/bkcs.2003.24.12.1725

315. Mehdi, S. H.; Hashim, R.; Ghalib, R. M.; Fátima C. Guedes da Silva, M.; Sulaiman, O.; Rahman, S. Z.; Murugaiyah, V.; Marimuthu, M. M. J. Mol. Struct. 2011, 1006, 318. http://dx.doi.org/10.1016/j.molstruc.2011.09.026

316. Belapure, S. A.; Beamer, Z. G.; Bartmess, J. E.; Campagna, S. R. Tetrahedron 2011, 67, 9265.

http://dx.doi.org/10.1016/j.tet.2011.09.102

317. Na, J. E.; Lee, K. Y.; Seo, J.; Kim, J. N. Tetrahedron Lett. 2005, 46, 4505. http://dx.doi.org/10.1016/j.tetlet.2005.04.117

318. Almog, J.; Rozin, R.; Klein, A.; Shamuilov-Levinton, G.; Cohen, S. Tetrahedron 2009, 65, 7954.

http://dx.doi.org/10.10/16j.tet.2009.07.056

319. Kasugai, K.; Hashimoto, S.; Imai, K.; Sakon, A.; Fujii, K.; Uekusa, H.; Hayashi, N.; Kobayashi, K. Cryst. Growth Des. 2011, 11, 4044.

http://dx.doi.org/10.1021/cg200554f

320. Das, S.; Fröhlich, R.; Pramanik, A. Synlett 2006, 207. http://dx.doi.org/10.1055/s-2006-926226

321. Klumpp, D. A.; Fredrick, S.; Lau, S.; Jin, K. K.; Bau, R.; Surya Prakash, G. K.; Olah, G. A. J. Org. Chem. 1999, 64, 5152. http://dx.doi.org/10.1021/j0990197h

322. Nieto, D. R.; Zolotukhin, M. G.; Fomina, L.; Fomine, S. J. Phys. Org. Chem. 2010, $23,878$. http://dx.doi.org/10.1002/poc.1680

323. Das, S.; Fröhlich, R.; Pramanik, A. J. Chem. Res. 2006, 2006, 84. http://dx.doi.org/10.3184/030823406776330891

324. Kundu, S. K.; Das, S.; Pramanik, A. J. Chem. Res. 2004, 2004, 781. http://dx.doi.org/10.3184/0308234043431654

325. Schönberg, A.; Mamluk, M. Chem. Ber. 1973, 106, 849. http://dx.doi.org/10.1002/cber.19731060315 
326. Sherif, M.; Assy, M.; Yousif, N.; Galahom, M. J. Iran. Chem. Soc. 2013, 10, 85. http//:dx.doi.org/10.1007/s13738-012-0128-X

327. Jew, S.-S.; Lim, D.-Y.; Kim, J.-Y.; Kim, S.-J.; Roh, E.-Y.; Yi, H.-J.; Ku, J.-M.; Park, B.-S.; Jeong, B.-S.; Park, H.-G. Tetrahedron: Asymmetry 2002, 13, 155.

http://dx.doi.org/10.1016/S0957-4166(02)00071-X

328. Gumina, G.; Cooperwood, J. S.; Chu, C. K. In Antiviral Nucleosides; Chu, C. K., Ed.; Elsevier: Amsterdam, 2003.

329. .Luo, M.-Z.; Liu, M.-C.; Mozdziesz, D. E.; Lin, T.-S.; Dutschman, G. E.; Gullen, E. A.; Cheng, Y.-C.; Sartorelli, A. C. Bioorg. Med. Chem. Lett. 2000, 10, 2145. http://dx.doi.org/10.1016/S0960-894X(00)00418-2

330. Chu, C. K.; Yadav, V.; Chong, Y. H.; Schinazi, R. F. J. Med. Chem. 2005, 48, 3949. http://dx.doi.org/10.1021/jm0500601

331. Yalpani, M.; Wilke, G. Chem. Ber. 1985, 118, 661. http://dx.doi.org/10.1002/cber.19851180225

332. Sakamoto, M.; Watanabe, M.; Mino, T.; Fujita, T.; Ohta, H.; Suzuki, S. Tetrahedron 2001, $57,4687$.

http://dx.doi.org/10.1016/S0040-4020(01)00394-5

333. Shaabani, A.; Teimouri, M. B.; Bijanzadeh, H. R. J. Chem. Res. 2003, 2003, 578. http://dx.doi.org/10.3184/030823403322597388

334. Leinweber, D.; Wartchow, R.; Butenschön, H. Eur. J. Org. Chem. 1999, 167. http://dx.doi.org/10.1002/(SICI)1099-0690(199901)1999:1<167::AID-EJOC167>3.0.CO;2$\underline{\mathrm{Z}}$

335. Leinweber, D.; Butenschön, H. Tetrahedron Lett. 1997, 38, 6385. http://dx.doi.org/10.1016/S0040-4039(97)01447-0

336. Leinweber, D.; Schnebel, M.; Wartchow, R.; Wey, H. G.; Butenschön, H. Eur. J. Org. Chem. 2002, 2002, 2385. http://dx.doi.org/10.1002/1099-0690(200207)2002:1::2385>4aid-ejoc2385>3.0.co;2-s

337. Mullican, M. D.; Sorenson, R. J.; Connor, D. T.; Thueson, D. O.; Kennedy, J. A.; Conroy, M. C. J. Med. Chem. 1991, 34, 2186. http://dx.doi.org/10.1021/jm00111a039

338. Fakhr, I. M. I.; Radwan, M. A. A.; El-Batran, S.; Abd El-Salam, O. M. E.; El-Shenawy, S. M. Eur. J. Med. Chem. 2009, 44, 1718. http://dx.doi.org/10.1016/j.ejmech.2008.02.034

339. Giri, R. S.; Thaker, H. M.; Giordano, T.; Williams, J.; Rogers, D.; Vasu, K. K.; Sudarsanam, V. Bioorg. Med. Chem. 2010, 18, 2796.

http://dx.doi.org/10.1016/j.bmc.2010.01.007

340. Prugh, J. D.; Hartman, G. D.; Mallorga, P. J.; McKeever, B. M.; Michelson, S. R.; Murcko, M. A.; Schwam, H.; Smith, R. L.; Sondey, J. M. J. Med. Chem. 1991, 34, 1805. http://dx.doi.org/10.1021/jm00110a008

341. Suzue, N.; Ishii, R.; Kamiya, R.; Wakabayashi, H.; Kobayashi, K. Heterocycles 2009, 78, 2467. 
http://dx.doi.org/10.3987/COM-09-11744

342. Harrison, W. T. A.; Morrison, B. J.; Musgrave, O. C. Tetrahedron 2004, 60, 9255. http://dx.doi.org/10/1016.j.tet.2004.07.066

343. Gonçalves, R. S. B.; Kaiser, C. R.; Lourenço, M. C. S.; de Souza, M. V. N.; Wardell, J. L.; Wardell, S. M. S. V.; da Silva, A. D. Eur. J. Med. Chem. 2010, 45, 6095. http://dx.doi.org/10.1016/j.ejmech.2010.09.024

344. Yu, L.; Zhou, W.; Wang, Z. Bioorg. Med. Chem. Lett. 2011, 21, 1541. http://dx.doi.org/10.1016/j.bmcl.2010.12.097

345. Ii, K.; Ichikawa, S.; Al-Dabbagh, B.; Bouhss, A.; Matsuda, A. J. Med. Chem. 2010, 53, 3793.

http://dx.doi.org/10.1021/jm100243n

346. Bekhit, A .A.; Fahmy, H. T. Y. Arch. Pharm. 2003, 336, 111. http://dx.doi.org/10.1002/ardp.200390007

347. Kamal, A.; Swapna, P.; Shetti, R. V. C. R. N. C.; Shaik, A. B.; Narasimha Rao, M. P.; Sultana, F.; Khan, I. A.; Sharma, S.; Kalia, N. P.; Kumar, S.; Chandrakant, B. Eur. J. Med. Chem. 2013, 64, 239.

http://dx.doi.org/10.1016/j.ejmech.2013.03.027

348. Mohammadizadeh, M. R.; Firoozi, N. Tetrahedron Lett. 2010, 51, 2467. http://dx.doi.org/10.1016/j.tetlet.2010.02.163

349. Barros, C. D.; Amato, A. A.; Oliveira ,T. B. d.; Iannini, K. B. R.; Silva, A. L. d.; Silva, T. G. d.; Leite, E. S.; Hernandes, M. Z.; Lima, M. d. C. A. d.; Galdino, S. L.; Neves, F. d. A. R.; Pitta, I. d. R. Bioorg. Med. Chem. 2010, 18, 3805. http://dx.doi.org/10.1016/j.bmc.2010.04.045

350. Sriharsha, S. N.; Satish, S.; Shashikanth, S.; Raveesha, K. A. Bioorg. Med. Chem. 2006, 14, 7476. http://dx.doi.org/10.1016/j.bmc.2006.07.014

351. Rao, A.; Carbone, A.; Chimirri, A.; De Clercq, E.; Monforte, A. M.; Monforte, P.; Pannecouque, C.; Zappalà ,M. Il Farmaco 2002, 57, 747. http://dx.doi.org/10.1016/S0014-827X(02)01268-5

352. Azizmohammadi, M.; Khoobi, M.; Ramazani, A.; Emami, S.; Zarrin, A.; Firuzi, O.; Miri, R.; Shafiee, A. Eur. J. Med. Chem. 2013, 59, 15. http://dx.doi.org/10.1016/j.ejmech.20.12.10.044

353. Liu, K.; Rao, W.; Parikh, H.; Li, Q.; Guo, T. L.; Grant, S.; Kellogg, G. E.; Zhang, S. Eur. J. Med. Chem. 2012, 47, 125.

http://dx.doi.org/10.1016/j.ejmech.2011.10.031

354. Serra, A. C.; Rocha Gonsalves, A. M. d. A.; Laranjo, M.; Abrantes, A. M.; Gonçalves, A. C.; Sarmento-Ribeiro, A. B.; Botelho, M. F. Eur. J. Med. Chem. 2012, 53, 398. http://dx.doi.org/10.1016/j.ejmech.2012.04.003

355. Kuhn, R.; Hammer, I. Chem. Ber. 1951, 84, 91. http://dx.doi.org/10.1002/cber.19510840115

356. Prota, G.; Ponsiglione, E. Tetrahedron 1973, 29, 4271. 
http://dx.doi.org/10.1016/0040-4020(73)80269-8

357. Rojanarata, T.; Opanasopit, P.; Ngawhirunpat, T.; Saehuan, C. Talanta 2010, 82, 444. http://dx.doi.org/10.1016/j.talanta.2010.01.016

358. Sotgia, S.; Zinellu, A.; Pisanu, E.; Pinna, G. A.; Deiana, L.; Carru, C. J. Chromatogr. A 2008, 1205, 90 . http://dx.doi.org/10.1016/j.chroma.2008.08.021

359. Sotgia, S.; Zinellu, A.; Pinna, G. A.; Deiana, L.; Carru, C. Talanta 2011, 85, 1783. http://dx.doi.org/10.1016/j.talanta.2011.07.007

360. Rezvanian, A.; Alizadeh, A.; Zhu, L. G. Synlett 2012, 23, 2526. http://dx.doi.org/10.1055/s-0032-1317181

361. Xue, J.; Diao, J.; Cai, G.; Deng, L.; Zheng, B.; Yao, Y.; Song, Y. ACS Med. Chem. Lett. 2012, 4, 278.

http://dx.doi.org/10.1021/ml300419r

362. Sashidhara, K. V.; Modukuri, R. K.; Choudhary, D.; Bhaskara Rao, K.; Kumar, M.; Khedgikar, V.; Trivedi, R. Eur. J. Med. Chem. 2013, 70, 802.

http://dx.doi.org/10.1016/j.ejmech.2013.10.060

363. Kojima, A.; Takita, S.; Sumiya ,T.; Ochiai, K.; Iwase, K.; Kishi, T.; Ohinata, A.; Yageta, Y.; Yasue, T.; Kohno, Y. Bioorg. Med. Chem. Lett. 2013, 23, 5311.

http://dx.doi.org/10.1016/j.bmcl.2013.07.069

364. Sangani, C. B.; Makawana, J. A.; Zhang, X.; Teraiya, S. B.; Lin, L.; Zhu, H.-L. Eur. J. Med. Chem. 2014, 76, 549. http://dx.doi.org/10.1016/j.ejmech.2014.01.018

365. Anchoori, R. K.; Kortenhorst, M. S. Q.; Hidalgo, M.; Sarkar, T.; Hallur, G.; Bai, R.; Diest, P. J. V.; Hamel, E.; Khan, S. R. J. Med. Chem. 2008, 51, 5953.

http://dx.doi.org/10.1021/jm800203e

366. Özdemir, A.; Turan-Zitouni, G.; Asım Kaplancıklı, Z.; İşcan, G.; Khan, S.; Demirci, F. Eur. J. Med. Chem. 2010, 45, 2080.

http://dx.doi.org/10.1016/j.ejmech.2009.12.023

367. Taniguchi, T.; Ogasawara, K. Org. Lett. 2000, 2, 3193. http://dx.doi.org/10.1021/o1006384f

368. Bhat, C.; Tilve, S. G. Tetrahedron 2013, 69, 6129. http://dx.doi.org/10.1016/j.tet.2013.05.055

369. Hu, S.; Gu, Q.; Wang, Z.; Weng, Z.; Cai, Y.; Dong, X.; Hu, Y.; Liu, T.; Xie, X. Eur. J. Med. Chem. 2014, 71, 259.

http://dx.doi.org/10.1016/j.ejmech.2013.11.013

370. Chen, X.; Zhan, P.; Pannecouque, C.; Balzarini, J.; De Clercq, E.; Liu, X. Eur. J. Med. Chem. 2012, 51, 60.

http://dx.doi.org/10.1016/j.ejmech.2012.02.019

371. Zhang, L. J.; Yan, C. G. Tetrahedron 2013, 69, 4915.

http://dx.doi.org/10.1016/j.tet.2013.04.048 
372. Kiruthika, S. E.; Vidhya Lakshmi, N.; Banu, B. R.; Perumal, P. T. Tetrahedron Lett. 2011, 52,6508 .

http://dx.doi.org/10.1016/j.tetlet.2011.09.119

373. Mohammadizadeh, M. R.; Azizian, J.; Teimouri, F.; Mohammadi, A. A.; Karimi, A. R.; Tamari, E. Can. J. Chem. 2008, 86, 925.

http://dx.doi.org/10.1139/v08-117

374. Azizian, J.; Mohammadizadeh, M. R.; Mohammadi, A. A.; Karimi, A. R.; Teimouri, F. Heteroat. Chem. 2007, 18, 16.

http://dx.doi.org/10.1002/hc.20242

375. Ghahremanzadeh, R.; Fereshtehnejad, F.; Bazgir, A. J. Heterocycl. Chem. 2010, 47, 1031. http://dx.doi.org/10.1002/jhet.412

376. Neuzil, E.; Tinguy-Moreaud, E.; Précigoux, G.; Nguyen Ba, C.; Courseille, C. In Amino Acids; Lubec, G., Rosenthal, G., Eds.; Springer Netherlands, 1992.

377. Leonard, M. S.; Hauze, D. B.; Carroll, P. J.; Joullié, M. M. Tetrahedron 2003, 59, 6933. http://dx.doi.org/10.1016/S0040-4020(03)00921-9

378. Leonard, M. S.; Carroll, P. J.; Joullié, M. M. Synth. Commun. 2004, 34, 863. http://dx.doi.org/10.1081/scc-120028359

379. Chen, Z.; Hu, G.; Li, D.; Chen, J.; Li, Y.; Zhou, H.; Xie, Y. Bioorg. Med. Chem. 2009, 17, 2351.

http://dx.doi.org/10.1016/j.bmc.2009.02.015

380. Manske, R. H. F.; Ahmed, Q. A. Can. J. Chem. 1970, 48, 1280. http://dx.doi.org/10.1139/v70-210

381. Yu, C. K.; MacLean, D. B. Can. J. Chem. 1971, 49, 3025. http://dx.doi.org/10.1139/v71-504

382. Rostamizadeh, S.; Nojavan, M.; Aryan, R.; Sadeghian, H.; Davoodnejad, M. Chin. Chem. Lett. 2013, 24, 629.

http://dx.doi.org/10.1016/j.cclet.2013.04.035

383. Gholap, A. R.; Toti, K. S.; Shirazi, F.; Deshpande, M. V.; Srinivasan, K. V. Tetrahedron 2008, 64, 10214. http://dx.doi.org/10.1016/j.tet.2008.08.033

384. Ravendra Babu, K.; Koteswara Rao, V.; Nanda Kumar, Y.; Polireddy, K.; Venkata Subbaiah, K.; Bhaskar, M.; Lokanatha, V.; Naga Raju, C. Antiviral Res. 2012, 95, 118. http://dx.doi.org/10.1016/j.antiviral.2012.05.010

385. Taylor, E. C.; Liu, B. J. Org. Chem. 2003, 68, 9938. http://dx.doi.org/10.1021/jo030248h

386. Amr, A.-G. E.; Mohamed, A. M.; Mohamed, S. F.; Abdel-Hafez, N. A.; Hammam, A. E.-F. G. Bioorg. Med. Chem. 2006, 14, 5481. http://dx.doi.org/10.1016/j.bmc.2006.04.045

387. Agarwal, A.; Srivastava, K.; Puri, S. K.; Chauhan, P. M. S .Bioorg. Med. Chem. 2005, 13, 4645.

http://dx.doi.org/10.1016/j.bmc.2005.04.061 
388. Costa, E. V.; Pinheiro, M. L. B.; Xavier, C. M.; Silva, J. R. A.; Amaral, A. C. F.; Souza, A. D. L.; Barison, A.; Campos, F. R.; Ferreira, A. G.; Machado, G. M. C.; Leon, L. L. P. J. Nat. Prod. 2006, 69, 292.

http://dx.doi.org/10.1021/np050422s

389. Katiyar, S. B.; Bansal, I.; Saxena, J. K.; Chauhan, P. M. S. Bioorg. Med. Chem. Lett. 2005, $15,47$.

http://dx.doi.org/10.1016/j.bmcl.2004.10.046

390. Penthala, N. R.; Yerramreddy, T. R.; Parkin, S.; Crooks, P. A. J. Heterocycl. Chem. 2013, 50, E156.

http://dx.doi.org/10.1002/jhet.1107

391. Meshram, G.; Wagh, P.; Deshpande, S.; Amratlal, V. Lett. Org. Chem. 2013, 10, 445. http://dx.doi.org/10.2174/1570178611310060006

392. Prashanth, M. K.; Revanasiddappa, H. D.; Lokanatha Rai, K. M.; Veeresh, B. Bioorg. Med. Chem. Lett. 2012, 22, 7065.

http://dx.doi.org/10.1016/j.bmcl.2012.09.089

393. Debnath, A. K. J. Med. Chem. 2003, 46, 4501. http://dx.doi.org/10.1021/jm030265z

394. ChenChenChen; Jiang, W.; Tucci, F.; Tran, J. A.; Fleck, B. A.; Hoare, S. R.; Joppa, M.; Markison, S.; Wen, J.; Sai, Y.; Johns, M.; Madan, A.; Chen, T.; Chen, C. W.; Marinkovic, D.; Arellano, M.; Saunders, J.; Foster, A. C. J. Med. Chem. 2007, 50, 5249.

http://dx.doi.org/10.1021/jm070806a

395. Benjahad, A.; Benhaddou, R.; Granet, R.; Kaouadji, M.; Krausz, P.; Piekarski, S.; Thomasson, F.; Bosgiraud, C.; Delebassée, S. Tetrahedron Lett. 1994, 35, 9545. http://dx.doi.org/10.1016/0040-4039(94)88507-9

396. Su, T.; Yang, H.; Volkots, D.; Woolfrey, J.; Dam, S.; Wong, P.; Sinha, U.; Scarborough, R. M.; Zhu, B.-Y. Bioorg. Med. Chem. Lett. 2003, 13, 729. http://dx.doi.org/10.1016/S0960-894X(02)01038-7

397. Katritzky, A. R.; Fan, W.-Q.; Szajda, M.; Li, Q.-L.; Caster, K. C. J. Heterocycl. Chem. 1988, 25, 591. http://dx.doi.org/10.1002/jhet.5570250243

398. Saha, S.; Venkata Ramana Reddy, C.; Chiranjeevi, T.; Addepally, U.; Chinta Rao, T. S.; Patro, B. Bioorg. Med. Chem. Lett. 2013, 23, 1013. http://dx.doi.org/10.1/016j.bmcl.2012.12.033

399. Seitz, L. E.; Suling, W. J.; Reynolds, R. C. J. Med. Chem. 2002, 45, 5604. http://dx.doi.org/10.1021/jm020310n

400. Le Bourdonnec, B.; Goodman, A. J.; Graczyk, T. M.; Belanger, S.; Seida, P. R.; DeHaven, R. N.; Dolle, R. E. J .Med. Chem. 2006, 49, 7290. http://dx.doi.org/10.1021/jm0604878

401. Kuo, G.-H.; Prouty, C.; Wang, A.; Emanuel, S.; DeAngelis, A.; Zhang, Y.; Song, F.; Beall, L.; Connolly, P. J.; Karnachi, P.; Chen, X.; Gruninger, R. H.; Sechler, J.; Fuentes-Pesquera , A.; Middleton, S. A.; Jolliffe, L.; Murray, W. V. J. Med. Chem. 2005, 48, 4892. 
http://dx.doi.org/10.1021/jm058205b

402. Xiao, Z.; Ye, G.; Liu, Y.; Chen, S.; Peng, Q.; Zuo, Q.; Ding, L. Angew. Chem. Int. Ed. 2012, $51,9038$.

http://dx.doi.org/10.1002/anie.201203981

403. Mazhukin, D. G.; Tikhonov, A. Y.; Volodarsky, L. B.; Evlampieva, N. y. P.; Vetchinov, V. P.; Mamatyuk, V. I. Liebigs Ann. Chem. 1994, 1994, 983.

http://dx.doi.org/10.1002/jlac.199419941005

404. Mazhakin, D. G.; Khlestkin, V. K.; Tikhonov, A. Y.; Volodarsky, L. B. Russ. Chem. Bull. 1996, 45,880 .

http://dx.doi.org/10.1007/bf01431317

405. Khalil, M. A. A. J. Heterocycl. Chem. 2012, 49, 806.

http://dx.doi.org/10.1002/jhet.867

406. Kumar, A.; Kumar, V.; Upadhyay, K. K. Tetrahedron Lett. 2011, 52, 6809. http://dx.doi.org/10.1016/j.tetlet.2011.10.046

407. Tisseh, Z. N.; Dabiri, M.; Nobahar, M.; Khavasi, H. R.; Bazgir, A. Tetrahedron 2012, 68, 1769.

http://dx.doi.org/10.1016/j.tet.2011.12.044

408. Tisseh, Z. N.; Dabiri, M.; Nobahar, M.; Soorki, A. A.; Bazgir, A. Tetrahedron 2012, 68, 3351.

http://dx.doi.org/10.1016/j.tet.2012.02.051

409. Torres, E.; Moreno-Viguri, E.; Galiano, S.; Devarapally, G.; Crawford, P. W.; Azqueta, A.; Arbillaga, L.; Varela, J.; Birriel, E.; Di Maio, R.; Cerecetto, H ;.González, M.; Aldana, I.; Monge, A.; Pérez-Silanes, S. Eur. J. Med. Chem. 2013, 66, 324.

http://dx.doi.org/10.1016/j.ejmech.2013.04.065

410. Wang, J.-F.; Kawabe, Y.; Shaheen, S. E.; Morrell, M. M.; Jabbour, G. E.; Lee, P. A.; Anderson, J.; Armstrong, N. R.; Kippelen, B.; Mash, E. A.; Peyghambarian, N. Adv. Mater. 1998, 10, 230.

http://dx.doi.org/10.1002/(sici)1521-4095(199802)10:3<230::aid-adma230>3.0.co;2-y

411. Justin Thomas, K. R.; Lin, J. T.; Tao, Y.-T.; Chuen, C.-H. Chem. Mater. 2002, 14, 2796. http://dx.doi.org/10.1021/cm0201100

412. Noolvi, M. N.; Patel, H. M.; Bhardwaj, V.; Chauhan, A. Eur. J. Med. Chem. 2011, 46, 2327. http://dx.doi.org/10.1016/j.ejmech.2011.03.015

413. Galal, S. A.; Abdelsamie, A. S.; Soliman, S. M.; Mortier, J.; Wolber, G.; Ali, M. M.; Tokuda, H.; Suzuki, N.; Lida, A.; Ramadan, R. A.; El Diwani, H. I. Eur. J. Med. Chem. 2013, 69, 115.

http://dx.doi.org/10.1016/j.ejmech.2013.07.049

414. Tandon, V. K.; Yadav, D. B.; Maurya, H. K.; Chaturvedi, A. K.; Shukla, P. K. Bioorg. Med. Chem. 2006, 14, 6120.

http://dx.doi.org/10.1016/j.bmc.2006.04.029 
415. Guillon, J.; Le Borgne, M.; Rimbault, C.; Moreau, S.; Savrimoutou, S.; Pinaud, N.; Baratin, S.; Marchivie, M.; Roche, S.; Bollacke, A.; Pecci, A.; Alvarez, L.; Desplat, V.; Jose ,J. Eur. J. Med. Chem. 2013, 65, 205. http://dx.doi.org/10.1016/j.ejmech.2013.04.051

416. Aly, A. A. J. Chem. Res. 2011, 35, 205. http://dx.doi.org/10.3184/174751911x13001124874111

417. Friedman, M. Can. J. Chem. 1967, 45, 2271. http://dx.doi.org/10.1139/v67-369

418. Deady, L. W.; Desneves, J.; Ross, A. C. Tetrahedron 1993, 49, 9823. http://dx.doi.org/10.1016/S0040-4020(01)80184-8

419. Kaupp, G.; Naimi-Jamal, M. R.; Schmeyers, J. Chem. Eur. J. 2002, 8, 594. http://dx.doi.org/10.1002/1521-3765(20020201::594>8:3(aid-chem594>3.0.co;2-5

420. Yadav, J. S.; Reddy, B. V. S.; Premalatha, K.; Shiva Shankar, K. Synthesis 2008, 2008, 3787. http://dx.doi.org/10.1055/s-0028-1083230

421. Srinivas, C.; Kumar, C. N. S. S. P.; Rao, V. J.; Palaniappan, S. J. Mol. Catal. A 2007, 265, 227. http://dx.doi.org/10.1016/j.molcata.2006.10.018

422. Guedat, P.; Boissy, G.; Borg-Capra, C.; Colland, F.; Daviet, L.; Formstecher, E.; Jacq, X.; Rain, J.-C.; Delansorne, R.; Vallese, S.; Colombo, M. Eur. Patent 1749822, 2007; Chem. Abstr. 2007, 146, 229381.

423. Morishita, H. U.S. Patent US8119828, 2012; Chem. Abstr. 2012, 149, 68057.

424. Schönberg, A.; Singer, E.; Hoyer, G.-A.; Rosenberg, D. Chem. Ber. 1977, 110, 3954. http://dx.doi.org/10.1002/cber.19771101229

425. Simakov, V. I.; Kurbatov, S. V.; Borbulevych, O. Y.; Antipin, M. Y.; Olekhnovich, L. P. Russ Chem Bull 2001, 50, 1064. http://dx.doi.org/10.1023/a:1011333722238

426. Kawamura, Y.; Morishita, H. Eur. Patent 2213662, 2012; Chem. Abstr. 2012, 150, 575552.

427. Amer, A. M.; El-Bahnasawi, A. A.; Mahran, M. R. H.; Lapib, M. Monatsh. Chem. 1999, $130,1217$. http://dx.doi.org/10.1007/p100010183

428. Liu, X.-W.; Xu, L.-C.; Li, H.; Chao, H.; Zheng, K.-C.; Ji, L.-N. J. Mol. Struct. 2009, 920, 163.

http://dx.doi.org/10.1016/j.molstruc.2008.10.038

429. Liu, X.-W.; Chen, Y.-D.; Li, L. J. Coord. Chem. 2012, 65, 3050. http//:dx.doi.org/10.1080/00958972.2012.710749

430. Azizian, J.; Mohammadizade, M. R.; Karimi, N.; Kazemizadeh, Z.; Mohammadi, A. A.; Karimi, A. R. Heteroat. Chem. 2005, 16, 549.

http://dx.doi.org/10.1002/hc.20136

431. Azizian, J.; Mohammadizade, M. R.; Karimi, N.; Mohammadi, A. A.; Karimi, A. R. Heterocycles 2005, 65, 143. 
http://dx.doi.org/10.3987/COM-04-10168

432. Azizian, J.; Karimi, A. R.; Kazemizadeh, Z.; Mohammadi, A. A.; Mohammadizadeh, M. R. Tetrahedron Lett. 2005, 46, 6155.

http://dx.doi.org/10.1016/j.tetlet.2005.06.099

433. Azizian, J.; Mohammadizadeh, M. R.; Zomorodbakhsh, S.; Mohammadi, A. A.; Karimi, A. R. Arkivoc 2007, 15, 24. http://dx.doi.org/10.3998/ark.5550190.0008.f04

434. Kumar, A.; Kumar, V.; Diwan, U.; Upadhyay, K. K. Sens. Actuators, B 2013, 176, 420. http://dx.doi.org/10.1016/j.snb.2012.09.089

435. Naskar, S.; Paira, P.; Paira, R.; Mondal, S.; Maity, A.; Hazra, A.; Sahu, K. B.; Saha, P.; Banerjee, S.; Luger, P.; Webe, M.; Mondal, N. B. Tetrahedron 2010, 66, 5196. http://dx.doi.org/10.1016/j.tet.2010.04.084

436. Ghalib, R. M.; Hashim, R.; Mehdi, S. H.; Sulaiman, O.; Pereira Silva, P. S.; Jassbi, A. R.; Firuzi, O.; Kawamura, F.; Chan, K.-L.; Murugaiyah, V. Lett. Drug Des. Discovery 2012, 9 , 767.

http://dx.doi.org/10.2174/15701801280.2652967

437. Olmo, E. d.; Barboza, B.; Ybarra, M. I.; López-Pérez, J. L.; Carrón, R.; Sevilla, M. A.; Boselli, C.; Feliciano, A. S. Bioorg. Med. Chem. Lett. 2006, 16, 2786. http://dx.doi.org/10.1016/j.bmcl.2006.02.003

438. Kagayama, K.; Morimoto, T.; Nagata, S.; Katoh, F.; Zhang, X.; Inoue, N.; Hashino, A.; Kageyama, K.; Shikaura, J.; Niwa, T. Bioorg. Med. Chem. 2009, 17, 6959. http://dx.doi.org/10.1016/j.bmc.2009.08.014

439. Cockcroft, X.-1.; Dillon, K. J.; Dixon, L.; Drzewiecki, J.; Kerrigan, F.; Loh Jr, V. M.; Martin, N. M. B.; Menear, K. A.; Smith, G. C. M. Bioorg. Med. Chem. Lett. 2006, 16, 1040. http://dx.doi.org/10.1016/j.bmcl.2005.10.081

440. Elagawany, M.; Ibrahim, M. A.; Ali Ahmed, H. E.; El-Etrawy, A. S.; Ghiaty, A.; AbdelSamii, Z. K.; El-Feky, S. A.; Bajorath, J. Bioorg. Med. Chem. Lett. 2013, 23, 2007. http://dx.doi.org/10.1016/j.bmcl.2013.02.027

441. Pathak, S.; Debnath, K.; Hossain, S. T.; Mukherjee, S. K.; Pramanik, A. Tetrahedron Lett. 2013, 54, 3137.

http://dx.doi.org/10.1016/j.tetlet.2013.04.015

442. Kundu, S. K.; Pramanik, A.; Patra, A. Synlett 2002, 2002, 823. http://dx.doi.org/10.1055/s-2002-25346

443. Kundu, S. K.; Pramanik, A. Indian J. Chem. 2004, 43B, 595.

http://dx.doi.org/10.1002/chin.200428162

444. Das, S.; Fröhlich, R.; Pramanik, A. J. Chem. Res. 2007, 2007, 5. http://dx.doi.org/10.3184/030823407780199603

445. Liu, H.-M.; Liu, F.-W.; Zou, D.-P.; Dai, G.-F. Bioorg. Med. Chem. Lett. 2005, 15, 1821. http://dx.doi.org/10.1016/j.bmcl.2005.02.024

446. Rano, T. A.; Sieber-McMaster, E.; Pelton, P. D.; Yang, M.; Demarest, K. T.; Kuo, G.-H. Bioorg. Med. Chem. Lett. 2009, 19, 2456. 
http://dx.doi.org/10.1016/j.bmcl.2009.03.051

447. Wallace, O. B.; Lauwers, K. S.; Jones, S. A.; Dodge, J. A. Bioorg. Med. Chem. Lett. 2003, 13, 1907. http://dx.doi.org/10.1016/S0960-894X(03)00306-8

448. Ramnauth, J.; Renton, P.; Dove, P.; Annedi, S. C.; Speed, J.; Silverman, S.; Mladenova, G.; Maddaford, S. P.; Zinghini, S.; Rakhit, S.; Andrews, J.; Lee, D. K. H.; Zhang, D.; Porreca, F. J. Med. Chem. 2012, 55, 2882. http://dx.doi.org/10.1021/jm3000449

449. Kumar, A.; Srivastava, S.; Gupta, G.; Chaturvedi, V.; Sinha, S.; Srivastava, R. ACS Comb. Sci. 2010, 13, 65. http://dx.doi.org/10.1021/co100022h

450. Lam, K.-H.; Lee, K. K.-H.; Gambari, R.; Wong, R. S.-M.; Cheng, G. Y.-M.; Tong, S.-W.; Chan, K.-W.; Lau, F.-Y.; Lai, P. B.-S.; Wong, W.-Y.; Chan, A. S.-C.; Kok, S. H.-L.; Tang, J. C.-O.; Chui, C.-H. Phytomedicine 2013, 20, 166. http://dx.doi.org/10.1016/j.phymed.2012.09.026

451. Rad-Moghadam, K.; Youseftabar-Miri, L. Synlett 2010, 1969. http://dx.doi.org/10.1055/s-0030-1258506

452. Rad-Moghadam, K.; Youseftabar-Miri, L. J. Fluorine Chem. 2012, 135, 213. http://dx.doi.org/10.1016/j.jfluchem.2011.11.007

453. Ramesh, E.; Manian, R. D. R. S.; Raghunathan, R.; Sainath, S.; Raghunathan, M. Bioorg. Med. Chem. 2009, 17, 660. http://dx.doi.org/10.1016/j.bmc.2008.11.058

454. Lei, Y.; Tan, J.; Wink, M.; Ma, Y.; Li, N.; Su, G. Food Chem. 2013, 136, 1117. http://dx.doi.org/10.1016/j.foodchem.2012.09.059

455. Aoki, S.; Watanabe, Y.; Tanabe, D.; Setiawan, A.; Arai, M.; Kobayashi, M. Tetrahedron Lett. 2007, 48, 4485.

http://dx.doi.org/10.1016/j.tetlet.2007.05.003

456. Piyanuch, R.; Sukhthankar, M.; Wandee, G.; Baek, S. J. Cancer Lett. 2007, 258, 230. http//:dx.doi.org/10.1016/j.canlet.2007.09.007

457. Jayaraman, M.; Fox, B. M.; Hollingshead, M.; Kohlhagen, G.; Pommier, Y.; Cushman, M. J. Med. Chem. 2001, 45, 242. http://dx.doi.org/10.1021/jm000498f

458. Venkov, A. P.; Lukanov, L. K. Synth. Commun. 1996, 26, 755. http://dx.doi.org/10.1080/00397919608086750

459. Tomasevich, L. L.; Kennedy, N. M.; Zitelli, S. M.; Troy Hull Ii, R.; Gillen, C. R.; Lam, S. K.; Baker, N. J.; Rohanna, J. C.; Conley, J. M.; Guerra, M. L.; Starr, M. L.; Sever, J. B.; Carroll, P. J.; Leonard, M. S. Tetrahedron Lett. 2007, 48, 599. http://dx.doi.org/10.1016/j.tetlet.2006.11.115

460. Yadav, J. S.; Reddy, B. V. S.; Reddy, U. V. S.; Praneeth, K. Tetrahedron Lett. 2008, 49, 4742 . http://dx.doi.org/10.1016/j.tetlet.2008.05.113 
461. Gavini, E.; Juliano, C.; Mulè, A.; Pirisino, G.; Murineddu, G.; Pinna, G. A. Arch. Pharm. 2000, 333, 341. http://dx.doi.org/10.1002/1521-4184(200010)333:10<341::aid-ardp341>3.0.co;2-u

462. Ravina, E.; Teran, C.; Dominguez, N. G.; Masaguer, C. F.; Gil-Longo, J.; Orallo, F.; Calleja, J. M. Arch. Pharm. 1991, 324, 455. http://dx.doi.org/10.1002/ardp.19913240710

463. Sacchi, A.; Laneri, S.; Arena, F.; Abignente, E.; Gallitelli, M.; D'Amico, M.; Filippelli, W.; Rossi, F. Eur. J. Med. Chem. 1999, 34, 1003. http//:dx.doi.org/10.1016/S0223-5234(99)00112-9

464. Tewari, A. K.; Mishra, A. Bioorg. Med. Chem. 2001, 9, 715. http://dx.doi.org/10.1016/S0968-0896(00)00285-6

465. Al-Tel, T. H. Eur. J. Med. Chem. 2010, 45, 5724. http://dx.doi.org/10.1016/j.ejmech.2010.09.029

466. Kneubühler, S.; Testa, B.; Carta, V.; Altomare, C.; Carotti, A. Helv. Chim. Acta 1993, 76, 1956.

http://dx.doi.org/10.1002/hlca.19930760514

467. Rao, V. R.; Kumar, P. V. J. Chem. Res. 2005, 2005, 267. http://dx.doi.org/10.3184/0308234054213447

468. Kneubuehler, S.; Thull, U.; Altomare, C.; Carta, V.; Gaillard, P.; Carrupt, P.-A.; Carotti, A.; Testa, B. J. Med. Chem. 1995, 38, 3874. http://dx.doi.org/10.1021/jm00019a018

469. Abdel-Latif, E.; Kaupp, G.; Metwally, M. A. J. Chem. Res. 2005, 2005, 187. http://dx.doi.org/10.3184/0308234054213735

470. Wu, G.-H.; Liu, Q.-C.; Tang, J. Heterocycles 2010, 81, 1157. http://dx.doi.org/10.3987/COM-09-11898

471. Wu, G.-H.; Liu, Q.-C. Chinese J. Struct. Chem. 2010, 29, 1155.

472. Klenke, B.; Stewart, M.; Barrett, M. P.; Brun, R.; Gilbert, I. H. J. Med. Chem. 2001, 44, 3440 . http://dx.doi.org/10.1021/jm010854+

473. Chen, X.; Zhan, P.; Liu, X.; Cheng, Z.; Meng, C.; Shao, S.; Pannecouque, C.; Clercq, E. D.; Liu, X. Bioorg. Med. Chem. 2012, 20, 3856. http://dx.doi.org/10.1016/j.bmc.2012.04.030

474. Chauhan, K.; Sharma, M.; Shivahare, R.; Debnath, U.; Gupta, S.; Prabhakar, Y. S.; Chauhan, P. M. S. ACS Med. Chem. Lett. 2013, 4, 1108. http://dx.doi.org/10.1021/ml400317e

475. Nenner, I.; Schulz, G. J. J. Chem. Phys. 1975, 62, 1747. http://dx.doi.org/10.1063/1.430700

476. Kannan, R.; He, G. S.; Lin, T.-C.; Prasad, P. N.; Vaia, R. A.; Tan, L.-S. Chem. Mater. 2003, 16,185 . http://dx.doi.org/10.1021/cm034358g 
477. Chang, C.-H.; Kuo, M.-C.; Lin, W.-C.; Chen, Y.-T.; Wong, K.-T.; Chou, S.-H.; Mondal, E.; Kwong, R. C.; Xia, S.; Nakagawa, T.; Adachi, C. J. Mater. Chem. 2012, 22, 3832. http://dx.doi.org/10.1039/c2jm14686j

478. Ried, W.; Schomann, P. Just. Liebigs Ann. Chem. 1968, 714, 128. http://dx.doi.org/10.1002/jlac.19687140113

479. Case, F. H. J. Heterocycl. Chem. 1972, 9, 457. http://dx.doi.org/10.1002/jhet.5570090251

480. Carotti, A.; Catto, M.; Leonetti, F.; Campagna, F.; Soto-Otero, R.; Méndez-Álvarez, E.; Thull, U.; Testa, B.; Altomare, C. J. Med. Chem. 2007, 50, 5364. http://dx.doi.org/10.1021/jm070728r

481. Ammar, Y. A.; El-Sehrawi, H. M.; El-Zahabi, H. S. A.; Shawer, T. Z.; Ismail, M. M. F. Der Pharm. Chem. 2012, 4, 2140.

482. Guedat, P.; Boissy, G.; Borg-Capra, C.; Colland, F.; Daviet, L.; Formstecher, E.; Jacq, X.; Rain, J.-C.; Delansorne, R.; Peretto, I.; Vignando, S. WO Patent WO2007066200, 2007; Chem. Abstr. 2007, 147, 72812.

483. Colland, F.; Colombo, M.; Daviet, L.; Formstecher, E.; Guedat, P.; Jacq, X.; Rain, J.-C. U.S. Patent 103149, 2008; Chem. Abstr. 2008, 148, 517736.

484. Ghosh, A. K.; Thompson, W. J.; McKee, S. P.; Duong, T. T.; Lyle, T. A.; Chen, J. C.; Darke, P. L.; Zugay, J. A.; Emini, E. A. J. Med. Chem. 1993, 36, 292.

http://dx.doi.org/10.1021/jm00054a015

485. .Dong, Y.; Nakagawa-Goto, K.; Lai, C.-Y.; Morris-Natschke, S. L.; Bastow, K. F.; Lee, K-. H. Bioorg. Med. Chem. Lett. 2011, 21, 2341.

http://dx.doi.org/10.1016/j.bmcl.2011.02.084

486. Fan, X.; Feng, D.; Qu, Y.; Zhang, X.; Wang, J.; Loiseau, P. M.; Andrei, G.; Snoeck, R.; Clercq, E. D. Bioorg. Med. Chem. Lett. 2010, 20, 809. http://dx.doi.org/10.1016/j.bmcl.2009.12.102

487. Aytemir, M. D.; Çaliş, Ü.; Özalp, M. Arch. Pharm. 2004, 337, 281. http://dx.doi.org/10.1002/ardp.200200754

488. Jin, S. S.; Ding, M. H.; Guo, H. Y. Heterocycl. Commun. 2013, 19, 139. http://dx.doi.org/10.1515/hc-2012-0159

489. Safaei, H. R.; Shekouhy, M.; Rahmanpur, S.; Shirinfeshan, A. Green Chem. 2012, 14, 1696. http://dx.doi.org/10.1039/c2gc35135h

490. Safaei, H.; Shekouhy, M.; Shirinfeshan, A.; Rahmanpur, S. Mol. Divers. 2012, 16, 669. http://dx.doi.org/10.1007/s11-9392-012-030z

491. Saluja, P.; Aggarwal, K.; Khurana, J. M. Synth. Commun. 2013, 43, 3239. http://dx.doi.org/10.1080/00397911.2012.760130

492. Jalili-Baleh, L.; Mohammadi, N.; Khoobi, M.; Ma'mani, L.; Foroumadi, A.; Shafiee, A. Helv. Chim. Acta 2013, 96, 1601. http://dx.doi.org/10.1002/hlca.201200516

493. Karimi, A. R.; Sedaghatpour, F. Synthesis 2010, 10, 1731. http://dx.doi.org/10.1055/s-0029-1219748 
494. Shaker, R. M.; Mahmoud, A. F.; Abdel-Latif, F. F. J. Chin. Chem. Soc. 2005, 52, 563. http://dx.doi.org/10.1002/jccs.200500083

495. He, Y.; Guo, H.; Tian, J. J. Chem. Res. 2011, 35, 528. http://dx.doi.org/10.3184/174751911X13149692358913

496. Khurana, J. M.; Yadav, S. Aust. J. Chem. 2012, 65, 314. http://dx.doi.org/10.1071/CH11444

497. Ghahremanzadeh, R.; Amanpour, T.; Bazgir, A. J. Heterocycl. Chem. 2010, 47, 46. http://dx.doi.org/10.1002/jhet.247

498. Kumar, V.; Bell, M. R.; Wetzel, J. R.; Herrmann, J. L.; McGarry, R.; Schane, H. P.; Winneker, R. C.; Snyder, B. W.; Anzalone, A. J. J. Med. Chem. 1993, 36, 3278. http://dx.doi.org/10.1021/jm00074a008

499. Lehmler, H.-J.; Nieger, M.; Breitmaier, E. Synthesis 1996, 1996, 105. http://dx.doi.org/10.1055/s-1996-4154

500. Hasaninejad, A.; Golzar, N.; Shekouhy, M.; Zare, A. Helv. Chim. Acta 2011, 94, 2289. http://dx.doi.org/10.1002/hlca.201100201

501. Hasaninejad, A.; Golzar, N.; Zare, A. J. Heterocycl. Chem. 2013, 50, 608. http://dx.doi.org/10.1002/jhet.1604

502. Lakshmi, N. V.; Suganya Josephine, G. A.; Perumal, P. T. Tetrahedron Lett. 2012, 53, 1282. http://dx.doi.org/10.1016/j.tetlet.2011.12.129

503. Bazgir, A.; Noroozi Tisseh, Z.; Mirzaei, P. Tetrahedron Lett. 2008, 49, 5165. http://dx.doi.org/10.1016/j.tetlet.2008.06.077

504. Ghaffari Khaligh, N. Catal. Sci. Technol. 2012, 2, 2211. http://dx.doi.org/10.1039/c2cy20276j

505. Regitz, M.; Heck, G. Chem. Ber. 1964, 97, 1482. http://dx.doi.org/10.1002/cber.19640970535

506. Regitz, M.; Schwall, H.; Heck, G.; Eistert, B.; Bock, G. Liebigs Ann. Chem. 1965, 690, 125. http://dx.doi.org/10.1002/jlac.19656900110

507. Teuber, H.-J.; Quintanilla-Licea, R. Liebigs Ann. Chem. 1989, 1989, 443. http://dx.doi.org/10.1002/jlac.198919890178

508. Hronowski, L. J. J.; Szarek, W. A. J. Med. Chem. 1982, 25, 522. http://dx.doi.org/10.1021/jm00347a008

509. Kawanishi, M.; Kotoku, N.; Itagaki, S.; Horii, T.; Kobayashi, M. Bioorg. Med. Chem. 2004, 12, 5297. http://dx.doi.org/10.1016/j.bmc.2004.04.051

510. Kim, H. Y.; Kuhn, R. J.; Patkar, C.; Warrier, R.; Cushman, M. Bioorg. Med. Chem. 2007, 15, 2667. http://dx.doi.org/10.1016/j.bmc.2007.01.040

511. Piergentili, A.; Quaglia, W.; Bello, F. D.; Giannella, M.; Pigini, M.; Barocelli, E.; Bertoni, S.; Matucci, R.; Nesi, M.; Bruni, B.; Vaira, M. D. Bioorg. Med. Chem. 2009, 17, 8174. http://dx.doi.org/10.1016/j.bmc.200.9.10.027

512. Schank, K.; Lieder, R.; Lick, C.; Glock, R. Helv. Chim. Acta 2004, 87, 869. 
http://dx.doi.org/10.1002/hlca.200490085

513. Hsieh, P.-W.; Chang, F.-R.; Chang, C.-H.; Cheng, P.-W.; Chiang, L.-C.; Zeng, F.-L.; Lin, K.-H.; Wu, Y.-C. Bioorg. Med .Chem. Lett. 2004, 14, 4751.

http://dx.doi.org/10.1016/j.bmcl.2004.06.083

514. Pietsch, M.; Gütschow, M. J. Med. Chem. 2005, 48, 8270. http://dx.doi.org/10.1021/jm0508639

515. Gütschow, M.; Kuerschner, L.; Neumann, U.; Pietsch, M.; Löser, R.; Koglin, N ;.Eger, K. J. Med. Chem. 1999, 42, 5437.

http://dx.doi.org/10.1021/jm991108w

516. Zhang, P.; Terefenko, E. A.; Fensome, A.; Wrobel, J.; Winneker, R.; Lundeen, S.; Marschke, K. B.; Zhang, Z. J. Med. Chem. 2002, 45, 4379.

http://dx.doi.org/10.1021/jm025555e

517. .Yavari, I.; Hossaini, Z.; Sabbaghan, M.; Ghazanfarpour-Darjani, M. Monatsh. Chem. 2007, $138,677$.

http://dx.doi.org/10.1007/s00706-007-0662-x

518. Campagna, F.; Carotti, A.; Casini, G.; Macripò, M. Heterocycles 1990, 31, 97. http://dx.doi.org/10/3987.COM-89-5149

519. Carotti, A.; Casini, G.; Gavuzzo, E.; Mazza, F. Heterocycles 1985, 23, 1659. http://dx.doi.org/10.3987/R-1985-07-1659

520. Carotti, A.; Casini, G.; Ferappi, M.; Cingolani, G. M. J. Heterocycl. Chem. 1980, 17, 1577. http://dx.doi.org/10.1002/jhet.5570170745

521. Wittmann, H.; Wurm, G. Monatsh. Chem. 1972, 103, 633. http://dx.doi.org/10.1007/BF00905424

522. Hassaan, A. M. A. Synth. React. Inorg. Met.-Org. Chem. 1997, 27, 855. http://dx.doi.org/10.1080/00945719708000233

523. Das ,S.; Koley, P.; Pramanik, A. Tetrahedron Lett. 2011, 52, 3243. http://dx.doi.org/10.1016/j.tetlet.2011.04.076

524. Yang, F.; Lian, G.; Yu, B. Carbohydr. Res. 2010, 345, 309. http://dx.doi.org/10.1016/j.carres.2009.11.020

525. Miyauchi, H.; Tanio, T.; Ohashi, N. Bioorg. Med. Chem. Lett. 1996, 6, 2377. http://dx.doi.org/10.1016/0960-894X(96)00435-0

526. Piergentili, A.; Quaglia, W.; Giannella, M.; Bello, F. D.; Bruni, B.; Buccioni, M.; Carrieri, A.; Ciattini, S. Bioorg. Med. Chem. 2007, 15, 886. http://dx.doi.org/10.1016/j.bmc.2006.10.040

527. Adam, W.; Fröhling, B. Org. Lett. 2000, 2, 2519. http://dx.doi.org/10.1021/o1000154j

528. Ukhin, L. Y.; Belousova, L. V.; Shepelenko, E. N.; Morkovnik, A. S. Mendeleev Commun. 2013, 23, 352.

http://dx.doi.org/10.1/016j.mencom.2013.11.017

529. Hamaguchi, M.; Takahashi, K.; Oshima, T.; Tamura, H. Tetrahedron Lett. 2003, 44, 4339. http://dx.doi.org/10.1016/S0040-4039(03)00936-5 
530. Akita, M.; Seto, H.; Aoyama, R.; Kimura, J.; Kobayashi, K. Molecules 2012, 17, 13879. http://dx.doi.org/10.3390/molecules171213879

531. Cheng, C.; Jiang, B.; Tu, S.-J.; Li, G. Green Chem. 2011, 13, 2107. http://dx.doi.org/10.1039/c1gc15183e

532. Piko, B. E.; Keegan, A. L.; Leonard, M. S. Tetrahedron Lett. 2011, 52, 1981. http://dx.doi.org/10.1016/j.tetlet.2011.02.068

533. Tolkunov, A. S.; Bogza, S. L. Chem. Heterocycl. Compd. 2010, 46, 711. http://dx.doi.org/10.1007/s10593-010-0573-3

534. Shapiro, R.; Agarwal, S. C. J. Am. Chem. Soc. 1968, 90, 474. http://dx.doi.org/10.1021/ja01004a045

535. Tolkunov, A. S.; Baumer, V. N.; Palamarchuk, G. V.; Shishkin, O. V.; Mazepa, A. V.; Tolkunov, S. V.; Bogza, S. L. Chem. Heterocycl. Compd. 2011, 47, 1006. http://dx.doi.org/10.1007/s10593-011-0867-0

536. Yavari, I.; Seyfi, S. Synlett 2012, 23, 1209. http://dx.doi.org/10.1055/s-0031-1290919

537. Pathak, S.; Pramanik, A. Eur. J. Org. Chem. 2013, 4410. http://dx.doi.org/10.1002/ejoc.201300096

\section{Authors' Biographies}

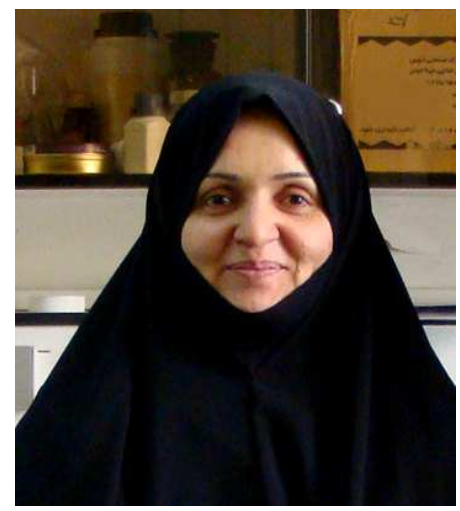

Ghodsi Mohammadi Ziarani was born in Iran, in 1964. She received her B.Sc. degree in Chemistry from the Teacher Training University, Tehran, Iran, in 1987, her M.Sc. degree in Organic Chemistry from the same university, under the supervision of Professor Jafar Asgarin and Professor Mohammad Ali Bigdeli in 1991. She obtained her Ph.D. degree in asymmetric synthesis (Biotransformation) from Laval University, Quebec, Canada under the supervision of Professor Chenevert, in 2000. She is an Associate Professor in the Science faculty of Alzahra University. Her research interests include organic synthesis, heterocyclic synthesis, asymmetric synthesis, natural products synthesis, synthetic methodology and applications of nano-heterogeneous catalysts in multicomponent reactions. 


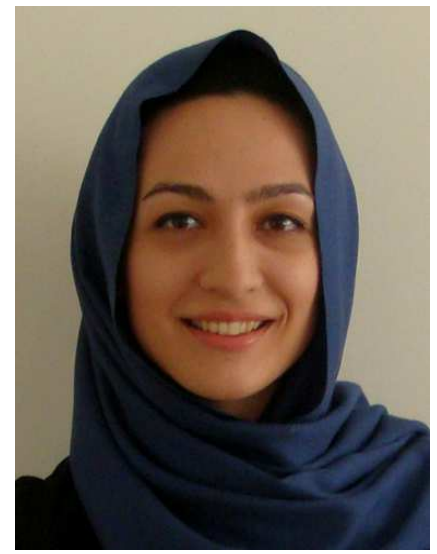

Negar Lashgari was born in 1985 in Tehran, Iran. She received her B.Sc. degree in Applied Chemistry from Tarbiat Moalem University, Tehran, Iran (2008) and her M.Sc. degree in Organic Chemistry at Alzahra University, Tehran, Iran (2011) under the supervision of Dr Ghodsi Mohammadi Ziarani. She is currently working towards her Ph.D. in Nano-Chemistry at the University of Tehran under the supervision of Dr Alireza Badiei and Dr Ghodsi Mohammadi Ziarani. Her research field is synthesis and application of nano-heterogeneous catalysts in multicomponent reactions.

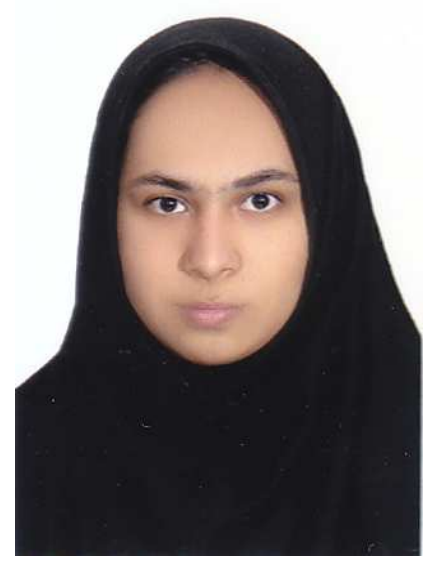

Fereshteh Azimian was born in 1989 in Qazvin, Iran. She received her B.Sc. degree from Imam Khomeini International University, Qazvin, Iran (2011). Presently she is working towards her M.Sc. degree in Organic Chemistry at Alzahra University. 


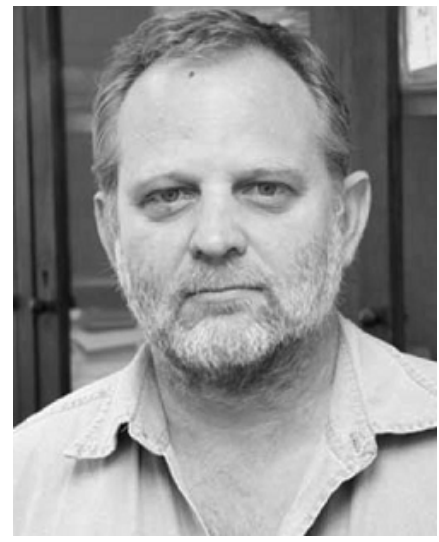

Gert (H. G.) Kruger graduated from Potchefstroom University, South Africa, in 1996 under the supervison of Frans (F. J. C.) Martins and Attie (A. M.) Viljoen. His Ph.D. lineage is traced back to Rudolf Criegee (Wutzburg) via Johan Dekker (Karlsruhe). The Dekkers introduced cage chemistry to South Africa, which Kruger actively pursues at the University of Kwazulu-Natal (see http://cpru.ukzn.ac.za).

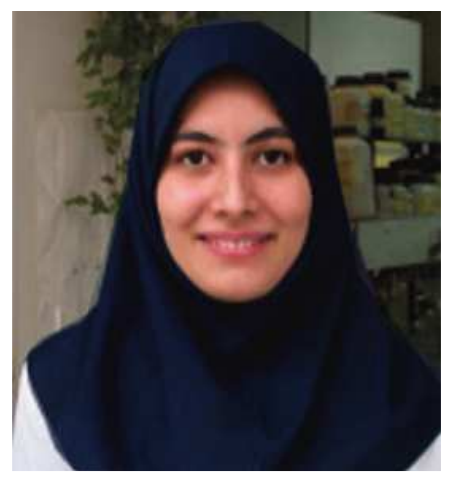

Parisa Gholamzadeh was born in 1986 in Tehran, Iran. She received her B.Sc. and M.Sc. from Alzahra University (2010 and 2012, respectively). Presently she is working towards her Ph.D. in Organic Chemistry at Alzahra University under the supervision of Dr. Ghodsi Mohammadi Ziarani. Her research field involves the synthesis of oxindole based heterocyclic compounds and application of heterogeneous catalysts in organic synthesis and multicomponent reactions. 